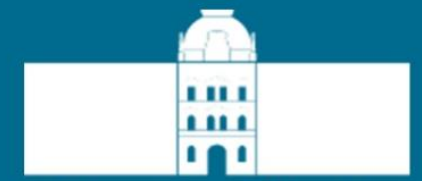

University of Maribor

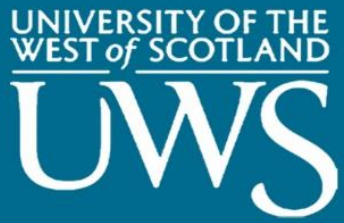

\title{
$10^{\mathrm{TH}}$ International Conference on Sustainable Energy and Environmental Protection:
}

\section{Hydrogen and Fuel Cells}

(June 27 ${ }^{T H}-30^{T H}, 2017$, Bled, Slovenia)

(Conference Proceedings)

\section{Editors:}

Emeritus Prof. dr. Jurij Krope Prof. dr. Abdul Ghani Olabi Prof. dr. Darko Goričanec Prof. dr. Stanislav Božičnik 
University of Maribor Press 


\title{
$10^{\mathrm{TH}}$ International Conference on Sustainable Energy and Environmental Protection
}

\author{
Hydrogen and Fuel Cells
}

(June 27 ${ }^{\mathrm{TH}}-30^{\mathrm{TH}}, 2017$, Bled, Slovenia)

(Conference Proceedings)

Editors:

Emeritus Prof. dr. Jurij Krope

Prof. dr. Abdul Ghani Olabi

Prof. dr. Darko Goričanec

Prof. dr. Stanislav Božičnik 
Title: $\quad 10^{\mathrm{TH}}$ International Conference on Sustainable Energy and Environmental Protection (June $27^{\mathrm{TH}}-30^{\mathrm{TH}}, 2017$, Bled, Slovenia) (Conference Proceedings)

Subtitle: Hydrogen and Fuel Cells

Editors: Emeritus Prof. Jurij Krope, Ph.D. (University of Maribor, Slovenia), Prof. Abdul Ghani Olabi, Ph.D. (University of the West of Scotland, UK), Asso. Prof. Darko Goričanec, Ph.D. (University of Maribor, Slovenia), Asso. Prof. Stanislav Božičnik (University of Maribor, Slovenia).

Review: Prof. Željko Knez, Ph.D. (University of Maribor, Slovenia), Prof. Niko Samec, Ph.D. (University of Maribor, Slovenia).

Tehnical editors : Jan Perša (University of Maribor Press), Armin Turanović (University of Maribor Press).

Design and layout: University of Maribor Press

Conference: $\quad 10^{\mathrm{TH}}$ International Conference on Sustainable Energy and Environmental Protection

Honorary Committee:

Abdul Ghani Olabi, Ph.D. (Honorary President, University of the West of Scotland, United Kingdom), Igor Tičar, Ph.D (Rector of the University of Maribor, Slovenia), Niko Samec $\mathrm{Ph} . D$. (Pro-rector of University of Maribor, Slovenia), Zdravko Kravanja, Ph-D. (Dean of the Faculty of Chemistry and Chemical Engineering, University of Maribor, Slovenia).

Organising Committee:

Jurij Krope, Ph.D. (University of Maribor, Slovenia), Darko Goričanec, Ph.D. (University of Maribor, Slovenia), Stane Božičnik, Ph.D. (University of Maribor, Slovenia), Peter Trop, Ph.D. (University of Maribor, Slovenia), Danijela Urbancl, Ph.D. (University of Maribor, Slovenia), Sonja Roj (University of Maribor, Slovenia), Željko Knez, Ph.D. (University of Maribor, Slovenia), Bojan Štumberger, Ph.D. (University of Maribor, Slovenia), Franci Čuš, Ph.D. (University of Maribor, Slovenia), Miloš Bogataj, Ph.D. (University of Maribor, Slovenia), Janez Žlak, Ph.D (Mine Trbovlje Hrastnik, Slovenia), LL. M. Tina Žagar (Ministry of Economic Development and Technology), Igor Ivanovski, MSc. (IVD Maribor, Slovenia), Nuša Hojnik, Ph.D. (Health Center Maribor).

Programme Committee:

Prof. Abdul Ghani Olabi (UK), Emeritus Prof. Jurij Krope (Slovenia), Prof. Henrik Lund (Denmark), Prof. Brian Norton (Ireland), Prof. Noam Lior (USA), Prof. Zdravko Kravanja (Slovenia), Prof. Jirí Jaromír Klemeš (Hungary), Prof. Stane Božičnik (Slovenia), Prof. Bojan Štumberger (Slovenia), Prof. Soteris Kalogirou (Cyprus), Prof. Stefano Cordiner (Italy), Prof. Jinyue Yan (Sweden), Prof. Umberto Desideri (Italy), Prof. M.S.J. Hashmi (Ireland), Prof. Michele Dassisti (Italy), Prof. Michele Gambino (Italy), Prof. S. Orhan Akansu (Turkey), Dr. David Timoney (Ireland), Prof. David Kennedy (Ireland), Prof. Bekir Sami Yilbas (Saudi Arabia), Dr. Brid Quilty (Ireland), Prof. B. AbuHijleh (UAE), Prof. Vincenc Butala (Slovenia), Prof. Jim McGovern (Ireland), Prof. Socrates Kaplanis (Greece), Dr. Hussam Jouhara (UK), Prof. Igor Tičar (Slovenia), Prof. Darko Goričanec (Slovenia), Dr. Joseph Stokes (Ireland), Prof. Antonio Valero (Spain), Prof. Aristide F. Massardo (Italy), Prof. Ashwani Gupta (USA), Dr. Aoife Foley (UK), Dr. Athanasios Megartis (UK), Prof. Francesco Di Maria (Italy), Prof. George Tsatsaronis (Germany), Prof. Luis M. Serra (Spain), Prof. Savvas Tassou (UK), Prof. Luigi Alloca (Italy), Prof. Faek Diko (Germany), Dr. F. Al-Mansour (Slovenia), Dr. Artur Grunwald (Germany), Dr. Peter Trop (Slovenia), Prof. Philippe Knauth (France), Prof. Paul Borza (Romania), Prof. Roy Douglas (UK), Prof. Dieter Meissner (Austria), Dr. Danijela Urbancl (Slovenia), Prof. Daniel Favrat (Switzerland), Prof. Erik Dahlquist (Sweden), Prof. Eric Leonhardt (USA), Prof. GianLuca Rospi (Italy), Prof. Giuseppe Casalino (Italy), Prof. J. Dawson (USA), Dr. Josè Simoes (Portugal), Prof. Kadir Aydin (Turkey), Dr. Khaled Benyounis (Ireland), Prof. Laszlo Garbai (Hungary), Prof. Mariano Martin (Spain), Prof. Masahiro Ishida (Japan), Prof. Michael Seal (USA), Prof. Marco Spinedi (Italy), Prof. Michio Kitano (Japan), Prof. Milovan Jotanović (BiH), Prof. Nafiz Kahraman (Turkey), Prof. Na Zhang (China), Prof. Naotake Fujita (Japan), Prof. Niko Samec (Slovenia), Prof. Oleksandr Zaporozhets (Ukraine), Prof. Osama Al-Hawaj (Kuwait), Prof. Petar Varbanov (Hungary), Prof. Peter Goethals (Belgium), Prof. Qi Zhang (China), Prof. Rik Baert (The Netherlands), Prof. Rolf Ritz (USA), Dr. Stephen Glover (UK), Prof. Signe Kjelstrup (Norway), Dr. Sumsun Naher (UK), Prof. Sven Andersson (Sweden), Dr. Salah Ibrahim (UK), Prof. Sebahattin Unalan (Turkey), Prof. Sabah Abdul-Wahab Sulaiman (Oman), Prof. Somrat Kerdsuwan (Thailand), Prof. T. Hikmet Karakoç (Turkey), Prof. Tahir Yavuz (Turkey), Prof. Hon Loong Lam (Thailand), LL.M. Tina Žagar (Slovenia), Prof. A.M.Hamoda (Qatar), Prof. Gu Hongchen (China), Prof. Haşmet Turkoglu (Turkey), Dr. Hussam Achour (Ireland), Dr. James Carton (Ireland), Dr. Eivind Johannes (Norway), Prof. Elvis Ahmetović (BiH), Prof. 
D.G.Simeonov (Bulgaria), Prof. Abdelakder Outzourhit (Morocco), Prof. Bilge Albayrak Çeper (Turkey), Prof. Bekir Zühtü Uysal (Turkey), Prof. D. Bradley (UK), Dr. Silvia Tedesco (UK), Dr. Valentin Ivanov (Germany), Dr. Vincent Lawlor (Austria), Prof. Yonghua Cheng (Belgium), Prof. Yasufumi Yoshimoto (Japan), Prof. Yahya Erkan Akansu (Turkey), Prof. Yunus Ali Çengel (Turkey), Prof. Zeljko Knez (Slovenia), Prof. Zoltan Magyar (Hungary), Dr. William Smith (Ireland), Dr. Abed Alaswad (UK).

First published in 2017 by

University of Maribor Press

Slomškov trg 15, 2000 Maribor, Slovenia

tel. +386225042 42, fax +38622523245

http://press.um.si, zalozba@um.si

\section{Co-published by}

University of Maribor, Faculty of Chemistry and Chemical Engineering

Smetanova ulica 17,2000 Maribor, Slovenia

tel. +386 (0)2 2294 400, faks + $386(0) 22527774$

http://www.fkkt.um.si, fkkt@um.si

Published: 5. July 2017

\section{(C) University of Maribor Press}

All rights reserved. No part of this book may be reprinted or reproduced or utilized in any form or by any electronic, mechanical, or other means, now known or hereafter invented, including photocopying and recording, or in any information storage or retrieval system, without permission in writing from the publisher.

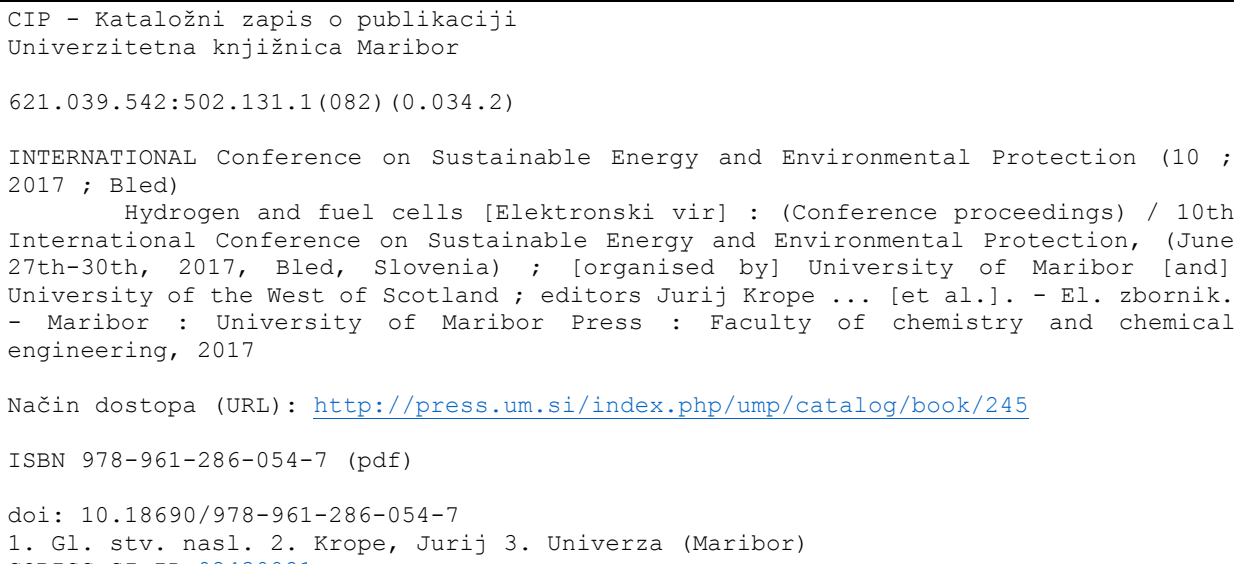

ISBN 978-961-286-054-7

DOI: https://doi.org/10.18690/978-961-286-054-7

Price: Free copy

For publisher: $\quad$ Prof. Igor Tičar, Ph.D., rector (University of Maribor) 
$10^{\mathrm{TH}}$ InTERNATIONAL CONFERENCE ON Sustainable ENERGy AND Environmental Protection (June 27 $7^{\mathrm{TH}}-30^{\mathrm{TH}}$, 2017, BLed, Slovenia), Hydrogen ANd Fuel Cells

J. Krope, A.Ghani Olabi, D. Goričanec \& S. Božičnik

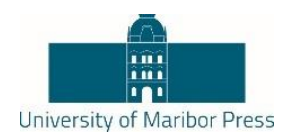

\section{Preface}

The $10^{\text {th }}$ International Conference on Sustainable Energy and environmental Protection SEEP 2017 was organised on June $27^{\text {th }}-30^{\text {th }} 2017$ in Bled, Slovenia, by:

- Faculty of Chemistry and Chemical Engineering, University of Maribor, Slovenia,

- University of the West of Scotland, School of Engineering and

The aim of SEEP2017 is to bring together the researches within the field of sustainable energy and environmental protection from all over the world.

The contributed papers are grouped in 18 sessions in order to provide access to readers out of 300 contributions prepared by authors from 52 countries.

We thank the distinguished plenary and keynote speakers and chairs who have kindly consented to participate at this conference. We are also grateful to all the authors for their papers and to all committee members.

We believe that scientific results and professional debates shall not only be an incentive for development, but also for making new friendships and possible future scientific development projects.

General chair

Emeritus Prof. dr. Jurij Krope
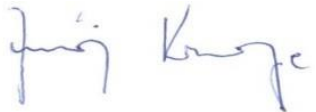
$10^{\mathrm{TH}}$ International CONFERENCE ON Sustainable ENERGY AND Environmental Protection (June 27 $7^{\mathrm{TH}}-30^{\mathrm{TH}}$, 2017, Bled, Slovenia), Hydrogen ANd Fuel Cells

J. Krope, A.Ghani Olabi, D. Goričanec \& S. Božičnik

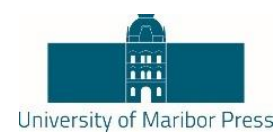

\title{
Plenary Talk on \\ The Relation between Renewable Energy and Circular Economy
}

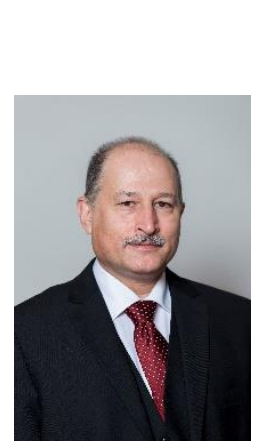

\author{
ABDUL GHANI OLABI - BIBLIOGRAPHY
}

Prof Olabi is director and founding member of the Institute of Engineering and Energy Technologies (www.uws.ac.uklieet) at the University of the West of Scotland. He received his M.Eng and Ph.D. from Dublin City University, since 1984 he worked at SSRC, HIAST, CNR, CRF, DCU and UWS. Prof Olabi has supervised postgraduate research students (10 M.Eng and 30PhD) to successful completion. Prof Olabi has edited 12 proceedings, and has published more than 135 papers in peer-reviewed international journals and about 135 papers in international conferences, in addition to 30 book chapters. In the last 12 months Prof Olabi has patented 2 innovative projects. Prof Olabi is the founder of the International Conference on Sustainable Energy and Environmental Protection SEEP, www.seepconference.co.uk

$\mathrm{He}$ is the Subject Editor of the Elsevier Energy Journal https://www.journals.elsevier.com/energy/editorial-board/abdul-ghani-olabi, also Subject editor of the Reference Module in Materials Science and Materials Engineering http://scitechconnect.elsevier.com/reference-module-material-science/ and board member of a few other journals. Prof Olabi has coordinated different National, EU and International Projects. He has produced different reports to the Irish Gov. regarding: Hydrogen and Fuel Cells and Solar Energy.

Correspondence AdDress: Abdul Ghani Olabi, Ph.D., Professor, University of the West of Scotland, School of Engineering and Computing, D163a, McLachlan Building, Paisley, United Kingdom, e-mail: Abdul.Olabi@uws.ac.uk. 
$10^{\mathrm{TH}}$ InTERNATIONAL CONFERENCE ON Sustainable ENERGy AND

Environmental Protection (June 27 $7^{\mathrm{TH}}-30^{\mathrm{TH}}$, 2017, Bled,

SLOVEnia), Hydrogen AND Fuel Cells

J. Krope, A.Ghani Olabi, D. Goričanec \& S. Božičnik

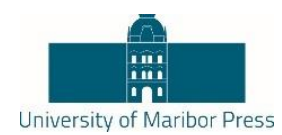

\title{
Plenary Talk on \\ Energy Footprints Reduction and Virtual Footprints Interactions
}

\author{
JIŘí JAROMÍR KLEMEŠ \& PETAR SABEV VARBANOV
}

Increasing efforts and resources have been devoted to research during environmental studies, including the assessment of various harmful impacts from industrial, civic, business, transportation and other economy activities. Environmental impacts are usually quantified through Life Cycle Assessment (LCA). In recent years, footprints have emerged as efficient and useful indicators to use within LCA. The footprint assessment techniques has provided a set of tools enabling the evaluation of Greenhouse Gas (GHG) - including $\mathrm{CO}_{2}$, emissions and the corresponding effective flows on the world scale. From all such indicators, the energy footprint represents the area of forest that would be required to absorb the GHG emissions resulting from the energy consumption required for a certain activity, excluding the proportion absorbed by the oceans, and the area occupied by hydroelectric dams and reservoirs for hydropower.

An overview of the virtual GHG flow trends in the international trade, associating the GHG and water footprints with the consumption of goods and services is performed. Several important indications have been obtained: (a) There are significant GHG gaps between producer's and consumer's emissions - US and EU have high absolute net imports GHG budget. (b) China is an exporting country and increasingly carries a load of GHG emission and virtual water export associated with consumption in the relevant importing countries. (c) International trade can reduce global environmental pressure by redirecting import to products produced with lower intensity of GHG emissions and lower water footprints, or producing them domestically.

To develop self-sufficient regions based on more efficient processes by combining neighbouring countries can be a promising development. A future direction should be focused on two main areas: (1) To provide the self-sufficient regions based on more efficient processes by combining production of surrounding countries. (2) To develop the shared mechanism and market share of virtual carbon between trading partners regionally and internationally.

CORRESPONDENCE AdDRESS: Jiř́ Jaromír Klemeš, DSc, Professor, Brno University of Technology - VUT Brno, Faculty of Mechanical Engineering, NETME Centre, Sustainable Process Integration Laboratory - SPIL, Technická 2896/2, 61669 Brno, Czech Republic, e-mail: klemes@fme.vutbr.cz. Petar Sabev Varbanov, Ph.D., Associate Professor, Brno University of Technology - VUT Brno, Faculty of Mechanical Engineering, NETME Centre, Sustainable Process Integration Laboratory - SPIL, Technická 2896/2, 61669 Brno, Czech Republic, e-mail: varbanov@fme.vutbr.cz. 
$10^{\mathrm{TH}}$ International CONFERENCE ON Sustainable ENERGY AND Environmental Protection (June 27 $7^{\mathrm{TH}}-30^{\mathrm{TH}}$, 2017, Bled, SLOVEnia), Hydrogen AND Fuel Cells

J. Krope, A.Ghani Olabi, D. Goričanec \& S. Božičnik

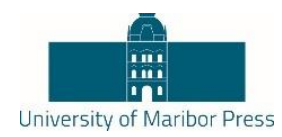

\section{JIŘÍ JAROMÍR KLEMEŠ - BIBLIOGRAPHY}

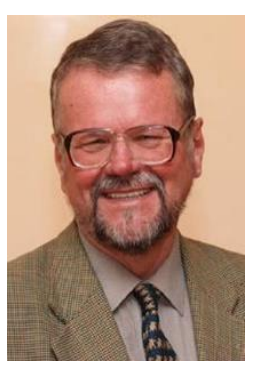

Head of "Sustainable Process Integration Laboratory - SPIL", NETME Centre, Faculty of Mechanical Engineering, Brno University of Technology - VUT Brno, Czech Republic and Emeritus Professor at "Centre for Process Systems Engineering and Sustainability", Pázmány Péter Catholic University, Budapest, Hungary.

Previously the Project Director, Senior Project Officer and Hon Reader at Department of Process Integration at UMIST, The University of Manchester and University of Edinburgh, UK. Founder and a long term Head of the Centre for Process Integration and Intensification - CPI2, University of Pannonia, Veszprém, Hungary. Awarded by the EC with Marie Curies Chair of Excellence (EXC). Track record of managing and coordinating 91 major EC, NATO and UK Know-How projects. Research funding attracted over $21 \mathrm{M€}$.

Co-Editor-in-Chief of Journal of Cleaner Production ( $\mathrm{IF}=4.959)$. The founder and President for 20 $\mathrm{y}$ of PRES (Process Integration for Energy Saving and Pollution Reduction) conferences. Chairperson of CAPE Working Party of EFCE, a member of WP on Process Intensification and of the EFCE Sustainability platform.

He authored nearly 400 papers, h-index 40. A number of books published by McGraw-Hill; Woodhead; Elsevier; Ashgate Publishing Cambridge; Springer; WILEY-VCH; Taylor \& Francis).

Several times Distinguished Visiting Professor for Universiti Teknologi Malaysia, Xi'an Jiaotong University; South China University of Technology, Guangzhou; Tianjin University in China; University of Maribor, Slovenia; University Technology Petronas, Malaysia; Brno University of Technology and the Russian Mendeleev University of Chemical Technology, Moscow. Doctor Honoris Causa of Kharkiv National University "Kharkiv Polytechnic Institute" in Ukraine, the University of Maribor in Slovenia, University POLITEHNICA Bucharest, Romania. "Honorary Doctor of Engineering Universiti Teknologi Malaysia", "Honorary Membership of Czech Society of Chemical Engineering", "European Federation of Chemical Engineering (EFCE) Life-Time Achievements Award" and "Pro Universitaire Pannonica" Gold Medal.

CORRESPONDENCE AdDRESS: Jiří Jaromír Klemeš, DSc, Professor, Brno University of Technology - VUT Brno, Faculty of Mechanical Engineering, NETME Centre, Sustainable Process Integration Laboratory - SPIL, Technická 2896/2, $616 \quad 69$ Brno, Czech Republic, e-mail: klemes@fme.vutbr.cz. 
$10^{\mathrm{TH}}$ InTERNATIONAL CONFERENCE ON Sustainable ENERGy AND Environmental Protection (June 27 $7^{\mathrm{TH}}-30^{\mathrm{TH}}$, 2017, Bled, Slovenia), Hydrogen ANd Fuel Cells

J. Krope, A.Ghani Olabi, D. Goričanec \& S. Božičnik

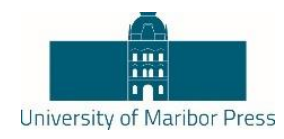

\title{
Plenary Talk on \\ Renewable energy sources for environmental protection
}

\author{
HAKAN SERHAD SOYHAN
}

Development in energy sector, technological advancements, production and consumption amounts in the countries and environmental awareness give shape to industry of energy. When the dependency is taken into account in terms of natural resources and energy, there are many risks for countries having no fossil energy sources. Renewable and clean sources of energy and optimal use of these resources minimize environmental impacts, produce minimum secondary wastes and are sustainable based on current and future economic and social societal needs. Sun is one of the main energy sources in recent years. Light and heat of sun are used in many ways to renewable energy. Other commonly used are biomass and wind energy. To be able to use these sources efficiently national energy and natural resources policies should be evaluated together with the global developments and they should be compatible with technological improvements. Strategic plans with regard to energy are needed more intensively and they must be in the qualification of a road map, taking into account the developments related to natural resources and energy, its specific needs and defining the sources owned by countries. In this presentation, the role of supply security was evaluated in term of energy policies. In this talk, new technologies in renewable energy production will be shown and the importance of supply security in strategic energy plan will be explained.

CorresPondence AdDress: Hakan Serhad Soyhan, Ph.D., Professor, Sakarya University, Engineering Faculty, Esentepe Campus, M7 Building, 54187 - Esentepe /Sakarya, Turkey, e-mail: hsoyhan@sakarya.edu.tr. 
$10^{\mathrm{TH}}$ InTERNATIONAL CONFERENCE ON Sustainable ENERGY AND Environmental Protection (June 27 $7^{\mathrm{TH}}-30^{\mathrm{TH}}$, 2017, Bled, SLOVENia), Hydrogen AND Fuel CELls

J. Krope, A.Ghani Olabi, D. Goričanec \& S. Božičnik

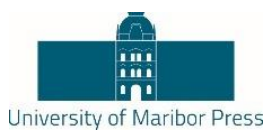

\section{HAKAN SERHAD SOYHAN - BIBLIOGRAPHY}

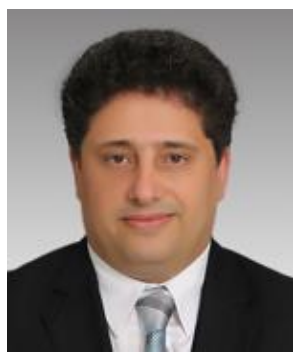

Professor at Sakarya University, Engineering Faculty. $50 \%$ fot teaching and the rest for reasearch activities.

Teaching, courses taught:

Graduate courses:

- Combustion technology;

- Modelling techniques;

Undergraduate courses:

- Combustion techniques;

- Internal combustion engines;

- Fire safety.

Tehnical skills and competences professional societies:

- 25 jurnal papers in SCI Index. 23 conference papers;

- $\quad$ Editor at FCE journal. Co-editor at J of Sakarya University;

- Head of Local Energy Research Society (YETA);

- Member od American Society of Mechanical engineers (ASME);

- Member of Turkish Society of Mechanical Engineers (TSME).

Correspondence AdDress: Hakan Serhad Soyhan, Ph.D., Professor, Sakarya University, Engineering Faculty, Esentepe Campus, M7 Building, 54187 - Esentepe /Sakarya, Turkey, e-mail: hsoyhan@sakarya.edu.tr. 

$10^{\mathrm{TH}}$ InTERnAtional CONFERENCE ON Sustainable ENERgy AND Environmental Protection (June $27^{\mathrm{TH}}-30^{\mathrm{TH}}$, 2017, Bled, Slovenia), Hydrogen and Fuel Cells

J. Krope, A.Ghani Olabi, D. Goričanec \& S. Božičnik

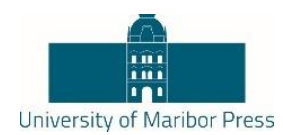

\section{Table of Contents}

\section{CONFERENCE PROCEEDINGS}

Composite Storage Systems for Compressed Hydrogen -

Systematic Improvement of Regulations for More Attractive Storage Units

Georg W. Mair, Ben Becker, Sebastian John \& Eric Duffner

Development of Pr2-XCaxNiO4 Cathode Materials for It-

Sofes Based on Oxygen-Ion and Proton-Conduting Solid State Electrolytes

Elena Pikalova, Nina Bogdanovich, Alexander Kolchugin, Dmitry Medvedev, Larisa Vedmid', Sergey Pikalov \& Sergey Plaksin

Experimental Study of Operational Parameters on the Performance of PEMFCS in Dead end Mode

Tabbi Wilberforce, Fawwad Nisar Khatib, Ogungbemi Emmanuel, Oluwatosin Ijeaodola, A. Abdulrahman, Ahmed Al Makky Ahmad Baroutaji \& Abdul Ghani Olabi

Characterisation of Proton Exchange Membrane (PEMFC)

Fuel Cell Through Design of Experiment (DOE)

Tabbi Wilberforce, Fawwad Nisar Khatib, Ahmed Al Makky, Ahmad Baroutaji \& Abdul Ghani Olabi

Cu/CGO Cermet Based Electrodes for

Symmetric and Reversible Solid Oxide Fuel Cells

Giovanni Carollo, Alberto Garbujo, Davide Ferri, Marta Maria Natile \& Antonella Glisenti

Improvement of a Hybrid Serpentine-Interdigitated Flow Field by Adjusting Numbers of Inlet and Outlet of Gas Flow Channels

Nuttapol Limjeerajarus \& Thatphong Santiprasertkul

Concept of an Integrated Thermally Self-Sustained Methanol

Steam Reformer - High-Temperature PEM Fuel Cell Stack Manportable System

Andrej Lotrič, Mihael Sekavčnik, Andrej Pohar, Blaž Likozar \& Stanko Hočevar 
Vladislav A. Sadykov, Elena Yu. Pikalova, Alexander A. Kolchugin, Nikita F. Eremeev, Nina M. Bogdanovich, Azat F. Khasanov, Pavel I. Skriabin, Alexey V. Krasnov, Ekaterina M. Sadovskaya, Alexander N. Shmakov, Zakhar S. Vinokurov, Arcady V. Ishchenko, Sergey M. Pikalov \& Elena A. Filonova

Novel Nanocomposite Materials for Oxygen Separation 97 Membranes

Vladislav A. Sadykov, Alexey V. Krasnov, Yulia E. Fedorova, Anton I. Lukashevich, Nikita F. Eremeev, Pavel I. Skriabin, Konstantin R. Valeev \& Oleg L. Smorygo

Electrochemical Resistance Reduction by Acid Treatment of Coal in Direct Carbon Fuel Cell

Seongyong Eom, Seongyool Ahn, Gyungmin Choi \& Duckjool Kim

Rapid Synthesis of $\mathrm{Co} / \mathrm{CeO}_{2}$ Nanoparticles for Selective 117 Oxidation of Carbon Monoxide in $\mathrm{H}_{2}$-Rich Stream Liping Zhong, Dingkai Chen, Kezhen Chen, Jichang Lu, Jing Wang, Caiyun Han \& Yongming Luo

The Effect of Chloride Ions in Sn Doped $\mathrm{CuO}-\mathrm{CeO}_{2}$ Catalysts for Co Preferential Oxidation (CO-PROX) in $\mathrm{H}_{2}$-Rich Stream Kezhen Chen, Liping Zhong, Jichang Lu, Gengping Wan \& Yongming Luo

Design and Testing of a Single-Cell PEM Electrolyser for Small-Scale Hydrogen Production Under Mild Conditions Antonio L. Tomas-Garcia, Mojtaba Mirzaeian, Greig Chisholm \& Abdul G. Olabi

European-Wide Field Trials for Residential Fuel Cell MicroCHP

Tadej Auer \& Mike Small

Exploring the Profit Potential of Energy Storage in a Car Park Using Electrolysis, Hydrogen Storage and Fuel Cell Electric Vehicles

Reinier van der Veen, Remco Verzijlbergh, Zofia Lukszo \& Ad van Wijk

Investigation on the Coupling of Fuel Cell with Photovoltaic and Parabolic Trough Solar Systems

Ahmad Haddad, Mahmoud Khaled, Mohamad Ramadan, Haitham Ramadan \& Mohamad Becherif 
State-of-the-Art Manufacturing Technologies of PEMFC Components

Abdulrahman Alanazi, Emmanuel Ogungbemi, A. Wilberforce, Oluwatosin S. Ijaodola, Parag Vichare \& Abdul-Ghani Olabi

Turbulent Burning Velocity of Mixture of Methane and a High Hydrogen Content Syngas

Arley Cardona Vargas, Alex M. García, Fabián E. Cano Ardila, Carlos E. Arrieta, Hernando A. Yepes \& Andrés A. Amell 
iv $\mid 10^{\mathrm{TH}}$ International CONFERENCE ON Sustainable EnERgy AND ENVIRONMENTAL Protection (June $27^{\mathrm{TH}}-30^{\mathrm{TH}}, 2017$, Bled, Slovenia), Hydrogen ANd Fuel CELlS Table of Contents 
$10^{\mathrm{TH}}$ INTERNATIONAL CONFERENCE ON Sustainable ENERgy AND ENVIRONMENTAL Protection (June $27^{\mathrm{TH}}-30^{\mathrm{TH}}$, 2017, Bled, Slovenia), Hydrogen ANd Fuel Cells

J. Krope, A.Ghani Olabi, D. Goričanec \& S. Božičnik

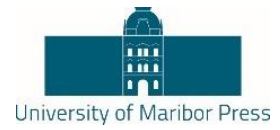

\title{
Composite Storage Systems for Compressed Hydrogen - Systematic Improvement of Regulations for More Attractive Storage Units
}

\author{
GEORG W. MAIR, BEN BECKER, SEBASTIAN JOHN \& ERIC DUFFNER
}

\begin{abstract}
Hydrogen is an attractive energy carrier that requires high effort for safe storage. For ensuring safety they have to undergo a challenging approval process. Relevant standards and regulations for composite cylinders used for the transport of for on-board storage of hydrogen are currently based on deterministic (e.g. ISO 11119-3) or semi-probabilistic (UN GTR No. 13) criteria. This paper analysis the properties of such methods in regards to the evaluation of load cycle strength. Their characteristics are compared with the probabilistic approach of the BAM. Based on Monte-Carlo simulations, the available design range (mean value and scatter of strength criteria) of current concepts were exemplarily estimated. The aspect of small sample sizes is analysed and discussed with respect to the evaluation procedures.
\end{abstract}

Keywords: $\bullet$ probabilistic $\bullet$ hydrogen $\bullet$ composite $\bullet$ cylinder $\bullet$ regulations

CORRESPONDENCE ADDRESS: Georg W. Mair, Dr.-Ing., Bundesanstalt für Materialforschung- und prüfung BAM (Federal Institute for Materials Research and Testing), Unter den Eichen 44-46 12203 Berlin, Germany, e-mail: georg.mair@bam.de. Ben Becker, Dr.-Ing., Bundesanstalt für Materialforschung- und prüfung BAM, Unter den Eichen 44-46 12203 Berlin, Germany, e-mail: ben.becker@BAM.de. Sebastian John, Bundesanstalt für Materialforschung- und prüfung BAM, Unter den Eichen 44-46 12203 Berlin, Germany, e-mail: sebastian.john@BAM.de. Eric Duffner, Bundesanstalt für Materialforschung- und prüfung BAM, Unter den Eichen 44-46 12203 Berlin, Germany, e-mail: eric.duffner@BAM.de. 
$10^{\mathrm{TH}}$ InTERnATIONAL CONFERENCE ON Sustainable ENERgy AND ENVIRONMENTAL Protection (June $27^{\mathrm{TH}}-30^{\mathrm{TH}}, 2017$, Bled, Slovenia), Hydrogen and Fuel Cells

G. W. Mair, B. Becker, S. John \& E. Duffner: Composite Storage Systems for Compressed Hydrogen - Systematic Improvement of Regulations for More Attractive Storage Units

\section{$1 \quad$ Introduction}

Hydrogen is an attractive energy carrier that needs to be compressed $\left(\mathrm{CGH}_{2}\right)$ or liquefied $\left(\mathrm{LH}_{2}\right)$ for storage and transport. The high storage pressure bares a risk of rupture with high consequences. Therefore $\mathrm{H}_{2}$-storage systems have to undergo an extensive approval process.. Relevant assessment criteria for approval and definition of retest periods of composite cylinders are intended to ensure a safe use over its entire service life. The overall aim is to avoid a critical failure during service. The risk of such a failure can never be completely eliminated but have to be reduced to an broadly accepted level In this case, the residual risk is accepted as a function of consequence.

The usual methods for the approval of composite cylinders for compressed hydrogen are based on determined minimum performance criteria. They follow the concept of a deterministic approach, i.e. the proof of minimum values with regards to burst pressure and load cycle strength.

The approval of composite cylinder for $\mathrm{CGH}_{2}$ storage systems for vehicles needs to follow the criteria from the UN GTR No. 13 [1]. In regards to burst pressure, this GTR 13 is based on an extended semi-probabilistic approach. This means, there is a specific minimum burst pressure as usual. But in addition to that the maximum scatter of the single burst test results is also limited. In regards to load cycle strength it is required to demonstrate a minimum number of load cycles (e.g. 11,000) without failure by testing just 3 specimens resisting.

BAM (Bundesanstalt für Materialforschung- und prüfung) has developed a probabilistic approach (PA) that could be developed to an alternative to the GTR 13.The BAM-PA [2], [3] is based on sample testing and statistical assessment on combination with reliability criteria. Sample means here always a group of nominal identically manufactured and used composite cylinders The approach is currently used by the BAM to determine retest periods for composite cylinders according to ADR / RID P200 (9) [4] and for service life tests for UN composite cylinders according to section 6.2.2.1.1 of IMDG Code [5] and ADR / RID.

The comparison of these different assessment methods leads to the question: Which level of safety do they ensure and how much potential do they offer for further optimization of composite cylinders?

Concerning burst pressure, this has been already investigated in [6] by using Monte-Carlo simulation. In the following, the Monte-Carlo simulation is extended to the statistical analysis of test results created by cycle testing with respect to the GTR 13 and the BAMPA. 
$10^{\mathrm{TH}}$ INTERNATIONAL CONFERENCE ON SUSTAINABLE ENERGY AND ENVIRONMENTAL Protection (June $27^{\mathrm{TH}}-30^{\mathrm{TH}}, 2017$, Bled, Slovenia), EnERgy Storage

G. W. Mair, B. Becker, S. John \& E. Duffner: Composite Storage Systems for Compressed Hydrogen - Systematic Improvement of Regulations for More Attractive

Storage Units

\section{Monte-Carlo Simulation}

The concept of a Monte-Carlo simulation [7] is based on a large number of computer generated samples. These samples result from a basic population following an assumed distribution function with defined properties. Due to a limited sample size n, mean value and scatter of a single sample deviate from the true characteristics of the original basic population.

This concept can be adopted to burst pressure and load cycle strength of composite cylinders. Corresponding studies on the statistical distribution of both performance parameters are presented in [8] and [9].

Figure 1 shows for example the variety of sample properties from burst tests according to GTR 13. Mean value and scatter of the samples are distributed around the true (but unknown) characteristics of the basic population. Each individual point in Figure 1 was generated by a Monte-Carlo simulation and represents burst values of a sample of 3 cylinders. The comparatively small sample size of $n=3$ creates a wide range of possible sample properties out of the same basic population. The challenge of an approval requirement is to identify potentially unsafe design types despite the high variability of the test results.

Figure 1 uses the sample performance chart (SPC) developed and applied by the BAM since 2012. The combined representation of mean value and scatter in relation to the test pressure $\mathrm{PH}$ enables the display of both properties relevant for a safety assessment. The shown scatter of sample properties results from the basic population with a mean burst pressure $\Omega_{50 \%}$ of $2.6 \mathrm{PH}$ and a scatter $\Omega_{\mathrm{s}}$ of $10 \%$ of PH.

When these generated samples are combined with an assessment criterion, they can be divided into two groups: Samples that meet the criterion (black) and those, which do not meet it (red). Figure 1 is based on the criterion according to GTR 13. Each of the three burst pressure values within a sample must exceed the test pressure PH by 1.5 times, i.e. the nominal working pressure (NWP) by 2.25 times. Additionally, each burst pressure needs to be within a range of $\pm 10 \%$ of the mean value $\Omega_{50 \%}$. 
$10^{\mathrm{TH}}$ InTERnAtional CONFerence on Sustainable EnERgy AND ENVIRONMENTAL Protection (June $27^{\mathrm{TH}}-30^{\mathrm{TH}}, 2017$, Bled, Slovenia), Hydrogen and Fuel Cells

G. W. Mair, B. Becker, S. John \& E. Duffner: Composite Storage Systems for Compressed Hydrogen - Systematic Improvement of Regulations for More Attractive Storage Units

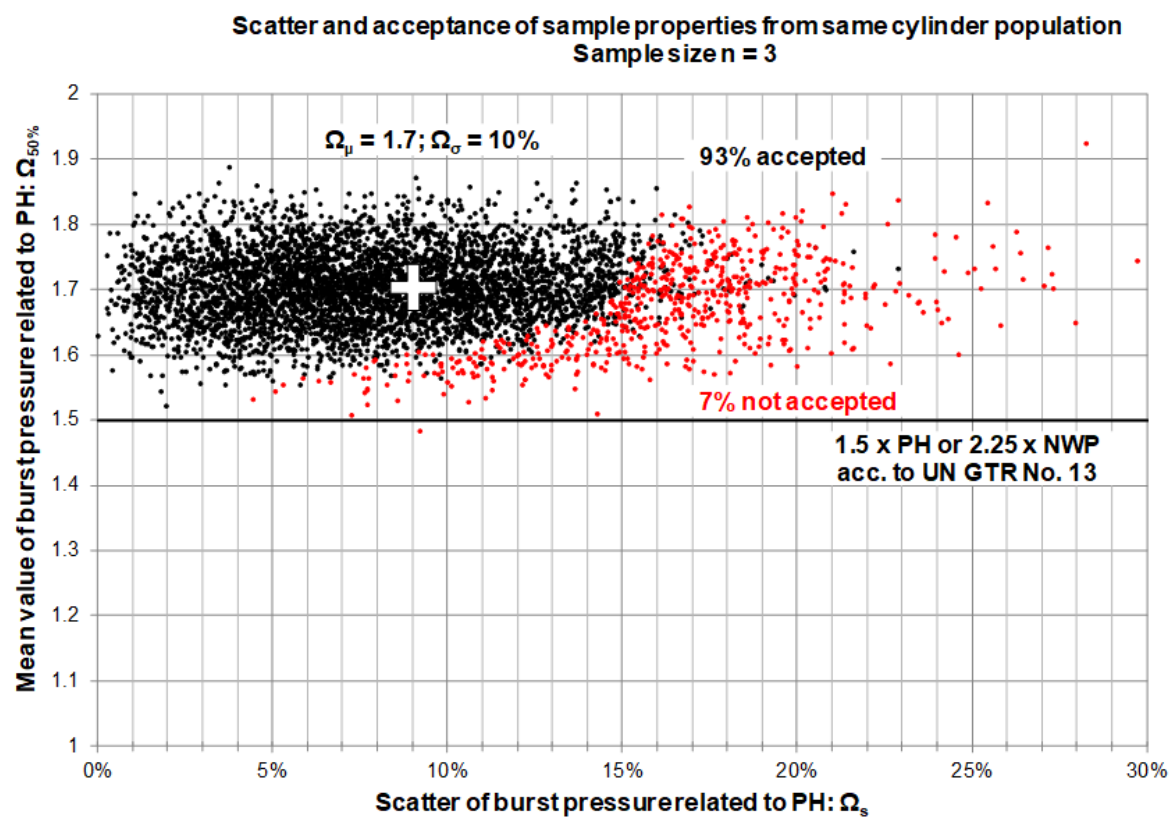

Figure 1. Monte-Carlo simulation of sample properties for a cylinder population $\Omega 50 \%=2.6 \mathrm{PH} ; \Omega \mathrm{s}=10 \% \mathrm{PH}$, assessed by UN GTR No. 13 .

As shown in Figure 2, around $93 \%$ of the generated samples include adequate test results and fulfill the burst criterion of the GTR 13. That means that the underlying basic population of composite cylinders would be accepted with a probability $93 \%$. This probability is called Acceptance Rate (AR). Conversely, the basic population would not meet the criterion with a probability of about $7 \%$.

The example shows that the evaluation of a small sample with $\mathrm{n}=3$ leads to considerable uncertainties. These uncertainties are always present and are usually covered by appropriate safety margins and additional tests. However, the decisive point of an assessment criterion should be the risk that an unsafe design type could be accepted - or even not.

To evaluate this it is necessary to clearly define the term "unsafe" respectively "safe". In the case of burst pressure, "safe" can be defined by the reliability or survival rate (SR) against a sudden rupture at a certain pressure [3], [4], [8]. A comparable criterion for load cycle strength can be defined based on the reliability against a leakage or sudden rupture after $\mathrm{N}$ further additional load cycles. In case of a composite cylinder at its end of service life $\mathrm{N}$ corresponds to just one (the very last) residual load cycle. 
$10^{\mathrm{TH}}$ INTERNATIONAL CONFERENCE ON SUSTAINABLE ENERGY AND ENVIRONMENTAL Protection (June $27^{\mathrm{TH}}-30^{\mathrm{TH}}, 2017$, Bled, Slovenia), EnERgy Storage

G. W. Mair, B. Becker, S. John \& E. Duffner: Composite Storage Systems for

Compressed Hydrogen - Systematic Improvement of Regulations for More Attractive

Storage Units

\section{$3 \quad$ Evaluation of un GTR 13}

The adoption of Monte-Carlo simulation to generate load cycle values requires a suitable assumption of the distribution function for the load cycle strength of composite cylinders. The average load cycle strength $\mathrm{N}_{50 \%}$ and scatter $\mathrm{N}_{\mathrm{s}}$ are obtained by a combination of Log-Normal and Weibull distribution [9] as shown in an adapted sample performance chart in Figure 2.

A high number of Monte-Carlo simulations for different combinations of $\mathrm{N}_{50 \%}$ and $\mathrm{N}_{\mathrm{s}}$ allows to calculate acceptance rates (AR) over the entire range of the SPC. Points from basic populations $\left(\mathrm{N}_{\mathrm{s}} ; \mathrm{N}_{50 \%}\right.$, ) with same $\mathrm{AR}$ are linked together to isolines of a constant acceptance rate.

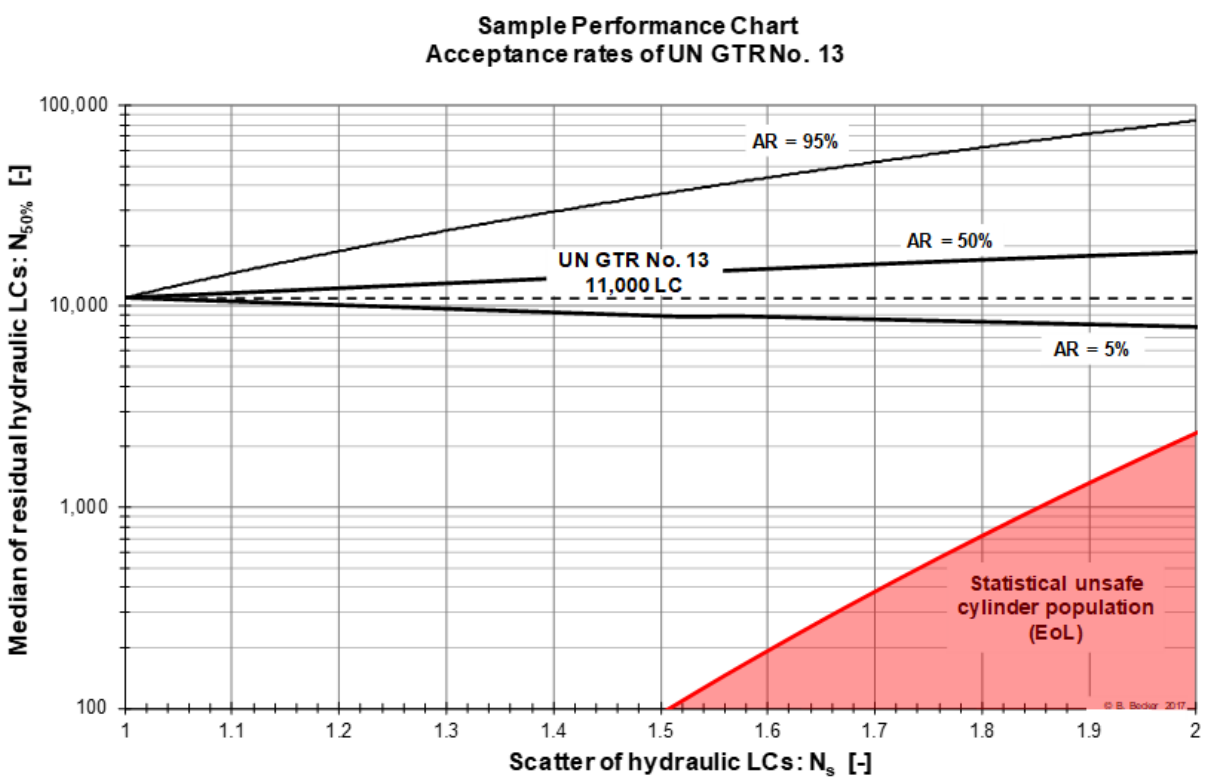

Figure 2. Iso-lines of acceptance rates for GTR 13 in comparison to statistically unsafe cylinder populations.

Figure 2 shows the distribution of AR for the load cycle criterion of GTR 13. For a better understanding: if the properties of a basic population of composite cylinders are located e.g. on the iso-line $\mathrm{AR}=50 \%$, there will be a probability of $50 \%$ that this basic population meets the requirement of GTR 13. Figure 2 combines the calculated isolines for AR with the safety criterion of a reliability of $1-10^{-6}(99.9999 \%)$ against failure at the next load cycle (red line). 
$10^{\text {TH }}$ InTERnational CONFERENCE ON Sustainable EnERgy AND ENVIRONMENTAL Protection (June $27^{\mathrm{TH}}-30^{\mathrm{TH}}, 2017$, Bled, Slovenia), Hydrogen and Fuel Cells

G. W. Mair, B. Becker, S. John \& E. Duffner: Composite Storage Systems for Compressed Hydrogen - Systematic Improvement of Regulations for More Attractive Storage Units

Two main questions arise in this context:

1. What is the acceptance rate for a potentially unsafe population of composite cylinders?

2. Which range of $\mathrm{N}_{50 \%}$ and $\mathrm{N}_{\mathrm{s}}$ can be used for designing composite cylinders acc. to GTR?

Concerning the first question, Figure 2 shows at very high scatter values of $\mathrm{N}_{\mathrm{s}}=2$ the general possibility to accept a basic population with a mean load cycle strength of N50\% $<11.000$ LC. The probability to accept a potentially unsafe cylinder population below the red line is less than $5 \%$ and consequently practically irrelevant.

For the second question, it can be assumed that an acceptance rate of above AR $=50 \%$ should be relevant in practice. Otherwise a design type would be conspicuous due to too many rejected batch tests and becomes therefore uneconomical. Acceptance rate of AR $=95 \%$ appears to be realistic from experience. The range between the line of AR $=95 \%$ and the red line of minimum reliability can be considered as a range of permissible reduction in load cycle strength during service life.

\section{Evaluation of BAM-PA}

A similar application of the Monte-Carlo simulation to the BAM-PA for the probabilistic assessment of load cycle strength is shown in Figure 3.

A cylinder population with reliability of less than $1-10^{-6}$ against failure (red line, compare [3], [6], [10]) is regarded as unsafe for further use. The already explained uncertainty of sample testing is covered in the PA by operating a confidence level of $95 \%$. Therefore, a sample needs to demonstrate at least an average strength for load cycles and a scatter value above the dotted line. Aim of this approach is to ensure that the acceptance rate of a potentially unsafe cylinder population is not significantly higher than $5 \%$. The shown example is based on a sample size of $n=5$ test results.

Figure 3 shows that in case of a cylinder population which is located on the line of the minimum requirement, a sample would be accepted by slightly more than $50 \%$.

The isoline of $\mathrm{AR}=95 \%$ limits the range of the de facto required properties for a cylinder population as otherwise the requirement would not be fulfilled very often.

\section{GTR 13 compared with BAM-PA}

Figure 4 shows the AR iso-lines for the GTR 13 and the BAM-PA. For the BAM-PA with $n=5$ the scatter $N_{S}$ of a cylinder population should be lower than 1.25 for reaching an acceptance rate of $\mathrm{AR}=95 \%$. In comparison, the GTR 13 allows to accept cylinder populations with a much higher scatter value. On the other hand, the BAM-PA allows accepting cylinder populations with very low mean load cycle strength in case of a scatter 
$10^{\mathrm{TH}}$ INTERNATIONAL CONFERENCE ON SUSTAINABLE ENERGY AND ENVIRONMENTAL Protection (June $27^{\mathrm{TH}}-30^{\mathrm{TH}}, 2017$, Bled, Slovenia), Energy Storage

G. W. Mair, B. Becker, S. John \& E. Duffner: Composite Storage Systems for Compressed Hydrogen - Systematic Improvement of Regulations for More Attractive

Storage Units

$\mathrm{N}_{\mathrm{s}}<1.2$. A low scatter value of load cycle strength leads to an increased reliability against failure. This is considered in the BAM-PA and demonstrates the general potential of weight and cost savings by probabilistic assessment criteria. A high production quality ensures a high reliability against failure even at lower mean load cycle strength.

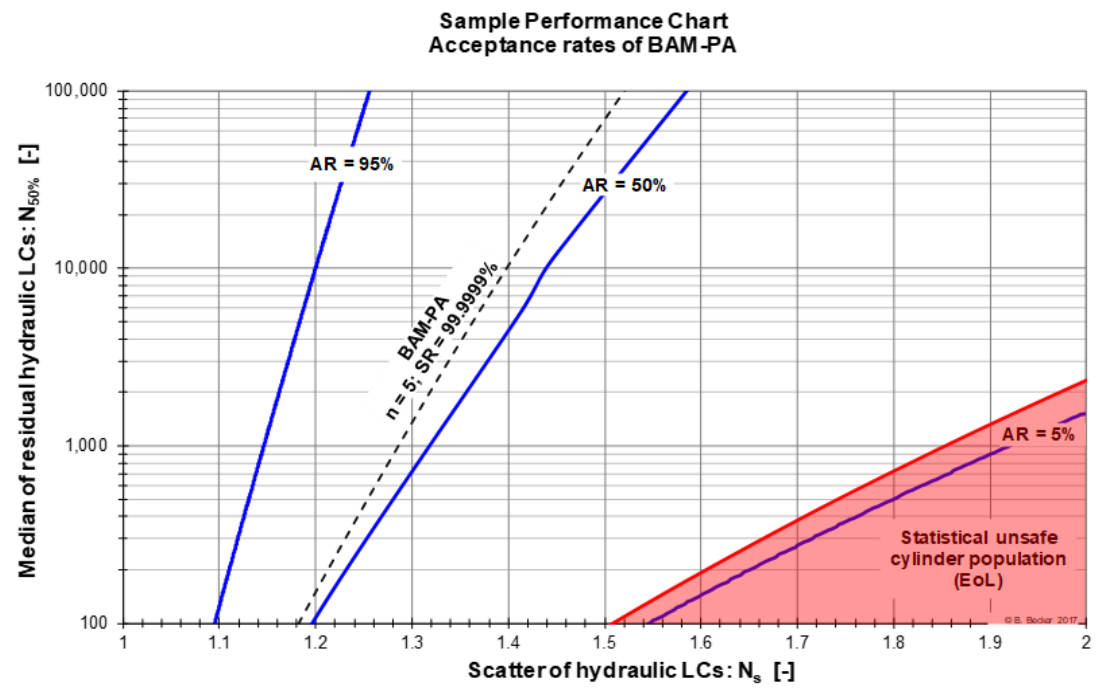

Figure 3. Isolines of acceptance rates for BAM-PA in comparison to statistical unsafe cylinder populations.

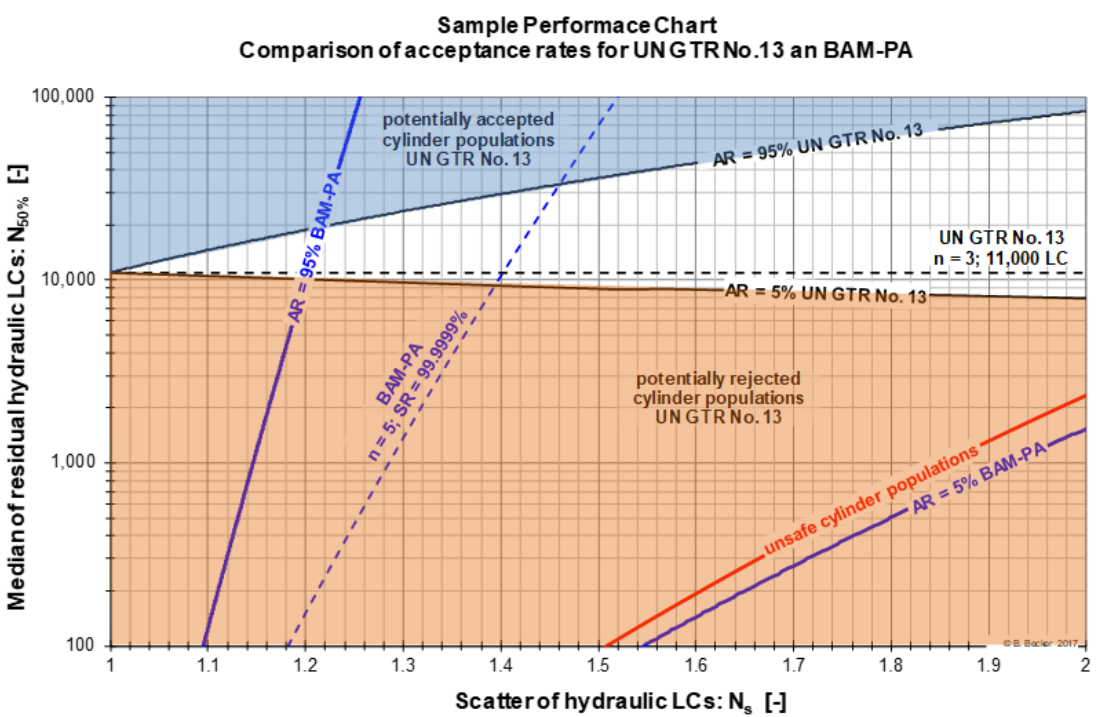

Figure 4. Requirements and of areas of acceptance for GTR 13 and BAM-PA. 
$10^{\mathrm{TH}}$ International Conference on Sustainable Energy and Environmental Protection (June $27^{\mathrm{TH}}-30^{\mathrm{TH}}, 2017$, Bled, Slovenia), Hydrogen and Fuel Cells

G. W. Mair, B. Becker, S. John \& E. Duffner: Composite Storage Systems for Compressed Hydrogen - Systematic Improvement of Regulations for More Attractive Storage Units

ven if the iso-line AR $=95 \%$ of the BAM-PA seems to reduce the scatter to a relatively small range this requirement is far less limiting the freedom for design in practical terms. In contrast to the GTR 13 and other standards based on deterministic requirements, a probabilistic assessment does not require fixed minimum values. It is important to look at the characteristics of the entire sample.

Therefore, it is possible within the BAM-PA to increase the sample size if necessary. This offers additional and more accurate information about a cylinder population. In practical use of the BAM-PA, an increased sample size often proves that the minimum requirement for the sample is met despite a critical first impression.

An increased sample size reduces the statistical uncertainty. Regarding Figure 3, this means that the dotted black line moves further right and allows higher scatter values.

The dependencies between sample size $\mathrm{n}$, scatter $\mathrm{N}_{\mathrm{s}}$ and mean load cycle strength $\mathrm{N}_{50 \%}$ are shown in Figure 5 for an acceptance rate of AR $=95 \%$.

The required load cycle strength which ensures a minimum reliability against failure for a sample scatter of $\mathrm{N}_{\mathrm{s}}=1.2$ is reduced from $10,000 \mathrm{LC}(\mathrm{n}=5)$ to $300 \mathrm{LC}(\mathrm{n}=10)$. This effect is directly related to reduced statistical uncertainties in case of a sample size of 10 test specimens versus a sample size of only 5 test specimens with otherwise similar properties.

Additional tests to increase the sample size for a statistical assessment cannot be compared with the very questionable praxis of retesting induvial results in deterministic procedures. In case of a statistical assessment all previous test results are still part of the sample. In contrast, retests procedures for deterministic requirements are ignoring previous test results.

\section{$5 \quad$ Conclusions}

It was shown that deterministic and probabilistic requirements are very different in terms of the acceptance of samples with high scatter values and potentially unsafe cylinder populations.

The used method of operating the Monte-Carlo simulation offers detailed analyses of approval criteria. Monte-Carlo simulation can be used to identify under which conditions minimum requirements could be reduced or changed without critical safety losses.

Especially probabilistic approval requirements would allow considerable improvements regarding the avoidance of critical cylinder populations. A probabilistic safety assessment offers a high potential for future optimization of cylinders designs. The consideration of scatter values provides additional information about production quality 
$10^{\mathrm{TH}}$ InTERNATIONAL CONFERENCE ON SUSTAINABLE ENERGY AND ENVIRONMENTAL Protection (June $27^{\mathrm{TH}}-30^{\mathrm{TH}}, 2017$, Bled, Slovenia), Energy Storage

G. W. Mair, B. Becker, S. John \& E. Duffner: Composite Storage Systems for

Compressed Hydrogen - Systematic Improvement of Regulations for More Attractive

Storage Units

and reliability and an optional increase of sample size allows immediate reactions on potential problems, too.

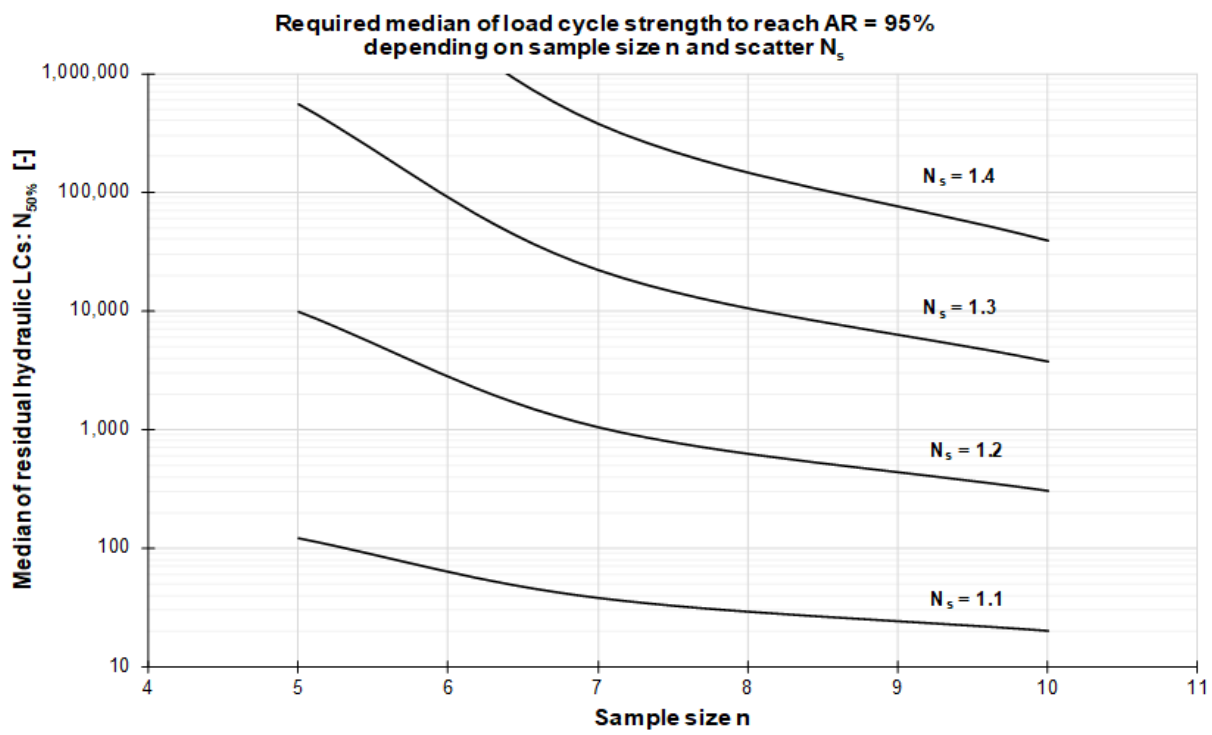

Figure 5. Required load cycle strength for BAM-PA to achieve an acceptance rate of $95 \%$ for specific scatter values of basic populations.

\section{References}

[1] UN GTR No. 13 - Global Technical Regulation Concerning the Hydrogen and Fuel Cell Vehicles, 2013.

[2] BAM - Official Publications: Dangerous Goods Containments - Composite Pressure Receptacles, Berlin, Germany, 2016. http://www.tes.bam.de/en/regelwerke/amtliche_mitteilungen/index.htm

[3] G.W. Mair, Sicherheitsbewertung von Composite-Druckgasbehältern - Potential statistischer Methoden jenseits aktueller Vorschriften, Springer-Verlag, Berlin 2016

[4] ADR/RID 2017, Techncial annexes to the European agreements concerning the international carriage of dangerous goods.

[5] International Maritime Code for Dangerous Goods (IMDG Code), Amendment 37-14, International Maritime Organization, London, UK, 2014.

[6] B. Becker, G.W. Mair, "Statistical analysis of burst requirements from regulations for composite cylinders in hydrogen transport”, Materials Testing, vol. 59, pp. 226-232, Mar. 2017.

[7] E. Zio, The Monte Carlo Simulation Method for System Reliability and Risk Analysis, London, 2013.

[8] B. Becker, G. W. Mair, F. Scherer, "Burst strength of composite cylinders - assessment of the type of statistical distribution” Materials Testing, vol. 56, pp. 642 -648, Sep. 2014. 
$10^{\mathrm{TH}}$ InTERnATIONAL CONFERENCE ON Sustainable EnERgy AND ENVIRONMENTAL Protection (June $27^{\mathrm{TH}}-30^{\mathrm{TH}}, 2017$, Bled, Slovenia), Hydrogen and Fuel Cells

G. W. Mair, B. Becker, S. John \& E. Duffner: Composite Storage Systems for Compressed Hydrogen - Systematic Improvement of Regulations for More Attractive Storage Units

[9] G.W. Mair, B. Becker, I. Scholz, "Assessment of the type of statistical distribution concerning strength properties of composite cylinders", $20^{\text {th }}$ ICCM, Copenhagen, 2015.

[10] B. Becker, G. W. Mair, "Risks and safety level of composite cylinders", Proceedings of WHEC 2016, pp. 34-35, Saragossa, 2016. 
$10^{\mathrm{TH}}$ InTERnATIONAL CONFERENCE ON Sustainable ENERgy AND EnVironmental Protection (June $27^{\mathrm{TH}}-30^{\mathrm{TH}}$, 2017, Bled, Slovenia), Hydrogen ANd Fuel Cells

J. Krope, A.Ghani Olabi, D. Goričanec \& S. Božičnik

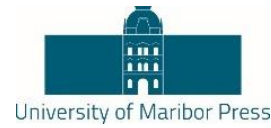

\title{
Development of $\mathrm{Pr}_{2}-\mathrm{XCaxNiO}_{4}$ Cathode Materials for It- Sofes Based on Oxygen-Ion and Proton-Conduting Solid State Electrolytes
}

\author{
Elena Pikalova, Nina Bogdanovich, AleXander Kolchugin, DMitry \\ MedvedeV, Larisa Vedmid, Sergey PiKalov \& Sergey PlaKsin
}

\begin{abstract}
Production of economically competitive solid oxide fuel cell (SOFC) systems requires development of new functional materials to enhance the performance, extend the lifetime and reduce the cost of the devices. The present work focuses on structural properties, electrical conductivity and thermal stability of $\mathrm{Pr}_{2}-\mathrm{xCaxNiO}_{4+\delta}$ oxide materials. Based on the study, electrochemically active and stable two-layer composite electrodes with $\operatorname{Pr}_{1.7} \mathrm{Ca}_{0.3} \mathrm{NiO}_{4+\delta}$-based functional layer and $\mathrm{LaNi}_{0.6} \mathrm{Fe}_{0.4} \mathrm{O}_{3-\delta}$ current collector were purposely proposed for use in intermediate temperature (IT) SOFCs with oxygen-ion and proton-conducting electrolytes.
\end{abstract}

Keywords: - SOFC • oxygen-ion electrolyte - proton-conducting electrolyte • $\mathrm{Pr}_{2} \mathrm{NiO}_{4} \bullet$ composite electrode $\bullet$

CoRrespondence AdDRess: Elena Pikalova, Ph.D., Senior Researcher, Institute of HighTemperature Electrochemistry UB RAS, Laboratory of Solid Oxide Fuel Cells, Academicheskaya str. 20, 620137 Yekaterinburg, Russia, Associate Professor, Leading Researcher, Department of Environmental Economics, Ural Federal University, Mira str. 19, 620002 Yekaterinburg, Russia, e-mail: e.pikalova@list.ru. Nina Bogdanovich., Researcher, Institute of High-Temperature Electrochemistry UB RAS, Laboratory of Solid Oxide Fuel Cells, Academicheskaya str. 20, 620137 Yekaterinburg, Russia, e-mail: bogdanovich@ihte.uran.ru. Alexander Kolchugin, Engineer, Institute of High-Temperature Electrochemistry UB RAS, Laboratory of Solid Oxide Fuel Cells, Academicheskaya str. 20, 620137 Yekaterinburg, Russia, e-mail: laba50@mail.ru. Medvedev, Ph.D., Senior Researcher, Institute of High-Temperature Electrochemistry UB RAS, Laboratory of Electrochemical Devices based on Solid Oxide Proton Electrolytes, Academicheskaya str. 20, 620137 Yekaterinburg, Russia; Senior Researcher, Department of Environmental Economics, Ural Federal University, Mira str. 19, 620002 Yekaterinburg, Russia email: dmitrymedv@ mail.ru. Larisa Vedmid', Ph.D., Senior Researcher, Institute of Metallurgy UB RAS, Laboratory of statics and kinetics of the processes, Amundsena str. 101, 620016 Yekaterinburg, Russia, elarisa100@mail.ru. Sergey Pikalov, Leading Engineer, Institute of Metallurgy UB RAS, Laboratory of pyrometallurgy of non-ferrous metals, Amundsena str. 101, Yekaterinburg 620016, Russia, e-mail: s.pikalov@mail.ru. Sergey Plaksin, PhD, Senior Researcher, Institute of High-Temperature Electrochemistry, Laboratory of Solid Oxide Fuel Cells, Academicheskaya str. 20, 620137 Yekaterinburg, Russia, e-mail: plaksin@ihte.uran.ru.

https://doi.org/10.18690/978-961-286-054-7.2

ISBN 978-961-286-054-7

(C) 2017 University of Maribor Press

Available at: http://press.um.si. 
$10^{\mathrm{TH}}$ InTERnATIONAL CONFERENCE ON Sustainable ENERgy AND ENVIRONMENTAL Protection (June $27^{\mathrm{TH}}-30^{\mathrm{TH}}, 2017$, Bled, Slovenia), Hydrogen and Fuel Cells E. Pikalova, N. Bogdanovich, A. Kolchugin, D. Medvedev, L. Vedmid, S. Pikalov \& S. Plaksin: Development of $\mathrm{Pr}_{2}-\mathrm{XCaxNiO}_{4}$ Cathode Materials for It-Sofcs Based on Oxygen-Ion and Proton-Conduting Solid State Electrolytes

Minimization of the resistance to the oxygen reduction reaction (ORR) at the cathode, which contributes the most to performance degradation and efficiency loss in the existing SOFCs, is a fundamental step for the application of SOFCs on a large scale. $\mathrm{Pr}_{2} \mathrm{NiO}_{4}$ (PNO) has attracted much attention as a promising cathode material for the IT-SOFCs due to a sufficiently low ASR value, but it is thermodynamically unstable under working SOFC's conditions and goes through subtle changes from $\mathrm{Pr}_{2} \mathrm{NiO}_{4}$, to $\mathrm{Pr}_{3} \mathrm{Ni}_{2} \mathrm{O}_{7}$, and to $\mathrm{Pr}_{4} \mathrm{Ni}_{3} \mathrm{O}_{10}[1,2]$. It has been demonstrated in a number of studies that partial substitution of $\mathrm{Pr}^{3+}$ in $\mathrm{Pr}_{2} \mathrm{NiO}_{4+\delta}$ with $\mathrm{La}^{3+}, \mathrm{Nd}^{3+}$ or $\mathrm{Sr}^{2+}$ enhances structural stability of the material, its conductivity and, in some cases, improves the electrochemical performance of the electrodes [3-7]. However, little information is available on the influence of other rareearth or alkali-earth elements on the structural, electrical and electrochemical properties of PNO.

The present work aims at studying the structural and electrical properties of $\mathrm{Pr}_{2-\mathrm{x}} \mathrm{Ca}_{\mathrm{x}} \mathrm{NiO}_{4+\delta}(\mathrm{x}=0.0-0.7, \mathrm{PCNO} 1-\mathrm{PCNO} 7)$ oxide materials, their thermal stability and electrochemical performance. The influence of calcium content on the polarization resistance of the electrodes has been studied by an impedance spectroscopy method; the results were compared with those for $\mathrm{PNO}$ and $\mathrm{Pr}_{1.7} \mathrm{Sr}_{0.3} \mathrm{NiO}_{4+\delta}$ (PSNO3) electrodes. A new design of electrochemically active and noble-metal free two-layer composite cathodes with PCNO functional layers and $\mathrm{LaNi}_{0.6} \mathrm{Fe}_{0.4} \mathrm{O}_{3-\delta}(\mathrm{LNF})$ current collector was proposed for use in IT-SOFCs in contact with oxygen-ion $\mathrm{Ce}_{0.8} \mathrm{Sm}_{0.2} \mathrm{O}_{2-\delta}(\mathrm{SDC})$ and proton-conducting $\mathrm{BaCe}_{0.8} \mathrm{Gd}_{0.19} \mathrm{Cu}_{0.01} \mathrm{O}_{3-\delta}(\mathrm{BCGCu})$ electrolytes. Long term stability of the developed electrodes was studied during 1500 hours at $700^{\circ} \mathrm{C}$ in air.

\section{Experimental}

$\mathrm{Pr}_{2-\mathrm{x}} \mathrm{Ca}_{\mathrm{x}} \mathrm{NiO}_{4+\delta}(\mathrm{x}=0.0-0.7), \mathrm{Pr}_{1.7} \mathrm{Sr}_{0.3} \mathrm{NiO}_{4+\delta}$ and $\mathrm{LaNi}_{0.6} \mathrm{Fe}_{0.4} \mathrm{O}_{3}$ (LNF) powders were synthesized by the two-step solid state reaction method using $\operatorname{Pr}_{2} \mathrm{O}_{3}$ (99.99\% purity), $\mathrm{La}_{2} \mathrm{O}_{3}(99.99 \%) \mathrm{NiO}(99.6 \%), \mathrm{CaCO}_{3}(99.6 \%), \mathrm{SrCO}_{3}(99.6 \%)$ and $\mathrm{Fe}_{2} \mathrm{O}_{3}(99.6 \%)$ with a final temperature of synthesis of $1250^{\circ} \mathrm{C}$ as in [8]. Characterization of the powders was performed by an XRD analysis (DMAX-2500, Rigaku Co. Ltd. Diffractometer with $\mathrm{Ni}$-filtered $\mathrm{CuK} \alpha$ radiation in the range of $20^{\circ} \leq 2 \theta \leq 80^{\circ}$ ). The oxygen nonstoichiometry $(\delta)$ was determined by long-term high-temperature treatment of the samples in an $10 \% \mathrm{H}_{2} / \mathrm{Ar}$ atmosphere at $850^{\circ} \mathrm{C}$ up to complete reduction. To study the thermal stability, the materials were calcined at $850^{\circ} \mathrm{C}$ in air for $250 \mathrm{~h}$ and then analyzed by XRD.

Conductivity of the compact samples of the related compositions was measured by employing a $d c$ four-probe technique.

For the electrochemical characterization the electrodes were fabricated symmetrically with in the form of two-layer coatings with functional and collector layers on the SDC and BCGCu electrolyte substrates. The functional layers of PCNO, PCNO-SDC and 
$10^{\mathrm{TH}}$ INTERNATIONAL CONFERENCE ON SUSTAINABLE ENERGY AND ENVIRONMENTAL Protection (June $27^{\mathrm{TH}}-30^{\mathrm{TH}}, 2017$, Bled, Slovenia), ENERGy Storage

E. Pikalova, N. Bogdanovich, A. Kolchugin, D. Medvedev, L. Vedmid, S. Pikalov \& S. Plaksin: Development of $\mathrm{Pr}_{2}-\mathrm{XCaxNiO}_{4}$ Cathode Materials for It-Sofcs Based on Oxygen-Ion and Proton-Conduting Solid State Electrolytes

PCNO-BCGCu (compositions were taken in 1:1 wt ratio) were placed onto a substrate by painting several times followed by sintering at $1200^{\circ} \mathrm{C}$ for $1 \mathrm{~h}$. Microstructure of the electrodes was examined by using a high resolution scanning electron microscope Mira 3 LMU, Tescan.

The electrochemical study was carried out using FRA-1260 with EI-1287 (Solartron Instruments Inc.) in a temperature range of $550-850^{\circ} \mathrm{C}$ in air in a frequency range of $0.01 \mathrm{~Hz}$ to $100 \mathrm{kHz}$ at the amplitude of applied sinusoidal signal of $20 \mathrm{mV}$. Each measurement was finished by measuring the full $d c$ - resistance $\left(R_{d c}\right)$ of the cell. The area specific polarization resistance $\left(R_{\eta}\right)$ of the electrochemical cell with symmetrically arranged electrodes was calculated as follows:

$$
R_{\eta}=\frac{\left(R_{d c}-R_{h f}\right) S}{2}
$$

where $S$ is the surface area of the electrode, and $R_{h f}$ is the serial resistance determined by extrapolation of the high-frequency part of an impedance spectrum to the intersection with the $\mathrm{x}$-axis. The impedance spectra were analyzed by using Zview software.

\section{$3 \quad$ Results and discussion}

\subsection{Structure}

According to the XRD data, the obtained PCNO materials were single phase (except 0.7 with trace amount of $\mathrm{NiO}$ ) and up to $\mathrm{x}=0.3$ possessed orthorhombic structure related to a high content of interstitial oxygen, $\delta$, changing from 0.255 for PNO to 0.091 for PCNO3 (Table 1). Since the $\mathrm{Pr}^{3+} \rightarrow \mathrm{Ca}^{2+}$ substitution does not cause distortions in the A sublattice due to the radii of host $\left(\mathrm{rPr}^{3+}=1.179 \AA\right)$ and substituting $\left(\mathrm{rCa}^{2+}=1.180 \AA\right)$ cations being close, the observed decrease in the cell parameters can be attributed to increased concentration of $\mathrm{Ni}^{3+}$ cations with smaller ionic radius as compared to that of $\mathrm{Ni}^{2+}\left(\mathrm{rNi}^{3+}\right.$ $=0.590 \AA$ and $\mathrm{rNir}^{2+}=0.660 \AA$ ), which appears for charge compensation. 
$14 \quad 10^{\mathrm{TH}}$ InTERnational CONFERENCE on Sustainable ENERGy AND ENVIRONMENTAL Protection (June $27^{\mathrm{TH}}-30^{\mathrm{TH}}, 2017$, Bled, Slovenia), Hydrogen and Fuel Cells E. Pikalova, N. Bogdanovich, A. Kolchugin, D. Medvedev, L. Vedmid, S. Pikalov \& S. Plaksin: Development of $\mathrm{Pr}_{2}-\mathrm{XCaxNiO}_{4}$ Cathode Materials for It-Sofcs Based on Oxygen-Ion and Proton-Conduting Solid State Electrolytes

Table 1. Structural parameters of PCNO and PSNO: orthorhombic (O) and tetragonal (T) structure

\begin{tabular}{|c|c|c|c|c|}
\hline \multirow[t]{2}{*}{$\mathrm{x}$} & \multirow{2}{*}{$\begin{array}{l}\text { Space } \\
\text { group }\end{array}$} & \multicolumn{3}{|c|}{ Lattice parameters } \\
\hline & & $a[\AA]$ & $b[\AA]$ & $c[\AA]$ \\
\hline 0 & $\mathrm{O}, \mathrm{Fmmm}$ & $\begin{array}{c}5.4703 \\
(6)\end{array}$ & $\begin{array}{c}5.3958 \\
(11)\end{array}$ & $12.4387(19)$ \\
\hline 0.1 & $\mathrm{O}, \mathrm{Fmmm}$ & $\begin{array}{c}5.4401 \\
(8)\end{array}$ & $\begin{array}{c}5.3965 \\
(7)\end{array}$ & $12.4351(13)$ \\
\hline 0.2 & $\mathrm{O}, \mathrm{Fmmm}$ & $\begin{array}{c}5.4453 \\
(4)\end{array}$ & $\begin{array}{c}5.4015 \\
(19)\end{array}$ & $12.3974(39)$ \\
\hline 0.3 & $\mathrm{O}, \mathrm{Fmmm}$ & $\begin{array}{c}5.3902 \\
(4)\end{array}$ & $5.39117(31)$ & $12.38127(89)$ \\
\hline 0.4 & $\mathrm{~T}, \mathrm{P} 42 / \mathrm{ncm}$ & $\begin{array}{c}5.3745 \\
(4)\end{array}$ & & $12.3627(13)$ \\
\hline 0.5 & $\mathrm{~T}, \mathrm{P} 42 / \mathrm{ncm}$ & $\begin{array}{c}5.3665 \\
(4)\end{array}$ & & $12.3494(16)$ \\
\hline 0.6 & $\mathrm{~T}, \mathrm{P} 42 / \mathrm{ncm}$ & $\begin{array}{c}5.3554 \\
(4)\end{array}$ & & $12.3081(16)$ \\
\hline $\begin{array}{l}0.3 \\
(\mathrm{Sr})\end{array}$ & $\mathrm{T}, \mathrm{I} 4 / \mathrm{mmm}$ & $\begin{array}{c}3.8129 \\
(2)\end{array}$ & & $12.4967(12)$ \\
\hline
\end{tabular}

At $x \geq 0.3$ there was a clear transition of doublets to singlets, which corresponded to the stabilization of a tetragonal $\mathrm{P} 42 / \mathrm{ncm}$ structure, which is characterised by low values of $\delta$ (0.013 for PCNO5). Nevertheless, all the prepared samples were hyperstoichiometric, similar to $\mathrm{Sr}^{2+}$ substituted PNO at $\mathrm{x}<0.5$ [3]. PSNO3 possessed a tetragonal $\mathrm{I} 4 \mathrm{mmm}$ structure with $\delta=0.011$.

Thermal stability of the structure increased with an increase in calcium content (Figure 1). 
$10^{\mathrm{TH}}$ INTERNATIONAL CONFERENCE ON SUSTAINABLE ENERGY AND ENVIRONMENTAL Protection (June $27^{\mathrm{TH}}-30^{\mathrm{TH}}, 2017$, Bled, Slovenia), ENERGy Storage

E. Pikalova, N. Bogdanovich, A. Kolchugin, D. Medvedev, L. Vedmid, S. Pikalov \& S.

Plaksin: Development of $\mathrm{Pr}_{2}-\mathrm{XCaxNiO}_{4}$ Cathode Materials for It-Sofcs Based on Oxygen-Ion and Proton-Conduting Solid State Electrolytes

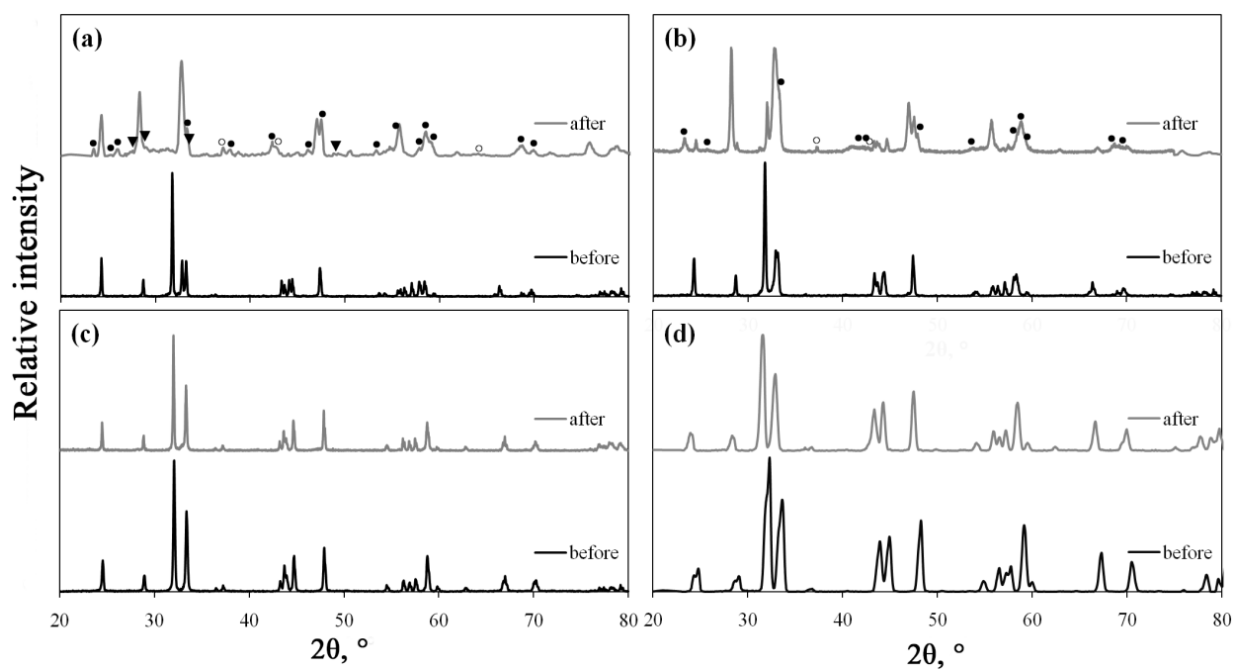

Figure 1. XRD patterns of PNO (a) and PCNO with $\mathrm{x}=0.1$ (b), 0.3(c); and 0.5(d) before and after long-term treatment during 250 hours at $850^{\circ} \mathrm{C}$ in air

As in the case of PNO, PCNO1 underwent a partial decomposition with formation of $\mathrm{PrO}_{1.83}$ along with the main phase. However, the second phase detected after decomposition of PCNO1 was $\mathrm{PrNiO}_{3}$ instead of $\mathrm{Pr}_{4} \mathrm{Ni}_{3} \mathrm{O}_{10}$ for $\mathrm{PNO}$. PCNO3 and PCNO5 showed excellent phase stability under long-term thermal treatment.

\subsection{Electrical properties}

Doping with calcium leads to a systematic increase in the electrical conductivity due to the increasing concentration of electron holes in the material caused by charge compensation (Figure 2). For $\mathrm{T}>500^{\circ} \mathrm{C}$ the conductivity decreases with temperature for the samples with low $\mathrm{x}$ and has no changes or increases for $\mathrm{x}>0.5$. 
$10^{\mathrm{TH}}$ InTERnAtional CONFERENCE ON Sustainable EnERgy AND ENVIRONMENTAL Protection (June $27^{\mathrm{TH}}-30^{\mathrm{TH}}, 2017$, Bled, Slovenia), Hydrogen and Fuel Cells E. Pikalova, N. Bogdanovich, A. Kolchugin, D. Medvedev, L. Vedmid, S. Pikalov \& S. Plaksin: Development of $\mathrm{Pr}_{2}-\mathrm{XCaxNiO}_{4}$ Cathode Materials for It-Sofcs Based on Oxygen-Ion and Proton-Conduting Solid State Electrolytes

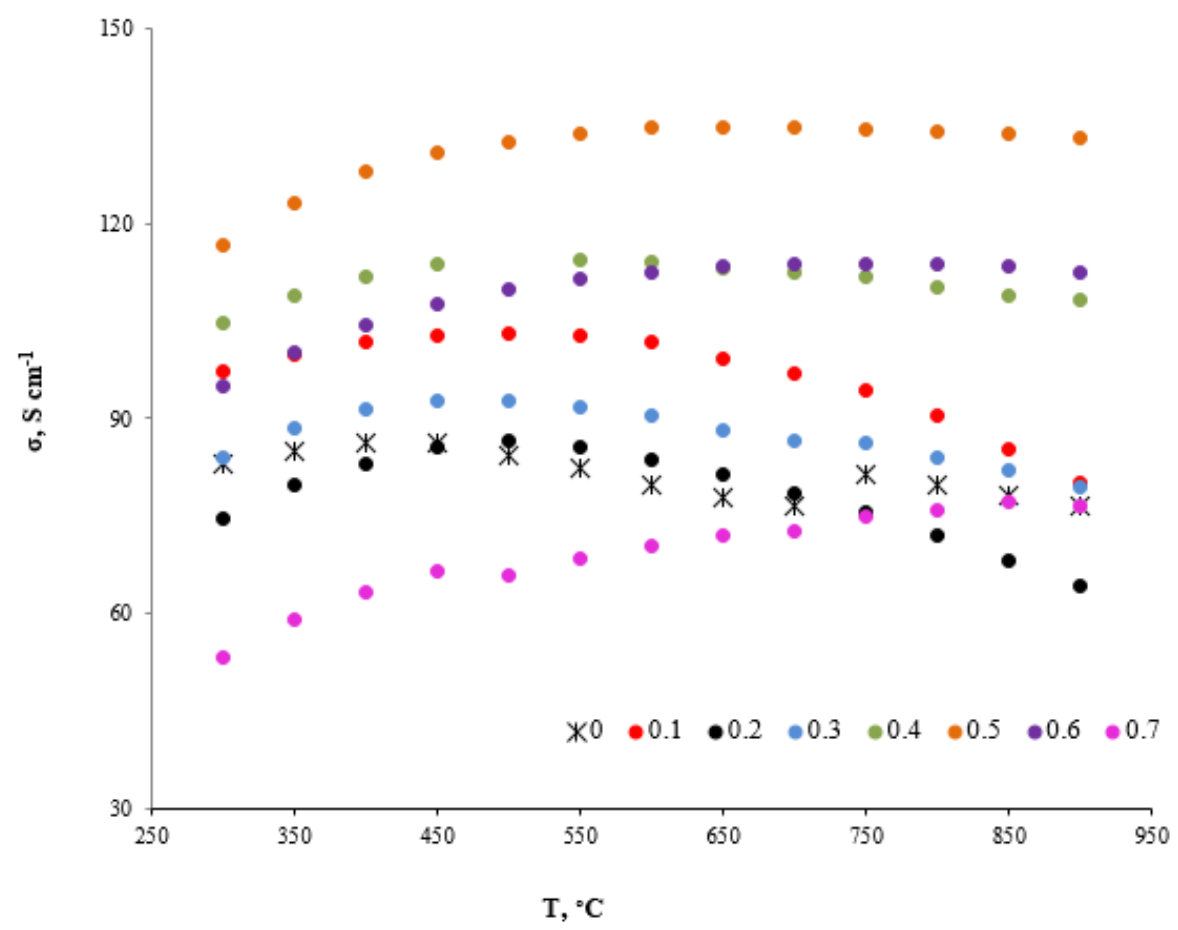

Figure 2. Temperature dependences of the total conductivity of the PCNO compacts

Similar conductivity decrease (for $\mathrm{T}>400^{\circ} \mathrm{C}$ ) was observed for $\mathrm{La}_{2-\mathrm{x}} \mathrm{Ca}_{\mathrm{x}} \mathrm{NiO}_{4+\delta}$ and related to a release of the interstitial oxygen from the layered structure in this temperature range, which lead to a partial annihilation of compensating holes [9]. With an increase in calcium content, oxygen exchange, as the temperature increases, becomes insignificant due to the low initial content of interstitial oxygen and conductivity shows semiconducting behavior across the whole temperature range. The maximal conductivity level was observed at $\mathrm{x}=0.5\left(135 \mathrm{~S} / \mathrm{cm}\right.$ at $\left.700^{\circ} \mathrm{C}\right)$; there are two probable reasons for its decreasing when $x>0.5$ : an appearance of impurity phases or the possible formation of electrically neutral defect associates [4].

\subsection{Electrochemical activity of the electrodes in contact with the SDC oxygen- ion conducting electrolyte}

Microstructure of the electrodes

Microstructure characterization of the electrodes was done using an original algorithm for the SEM image processing [10] (shown in Figure 3). It was found, that with an increase in $x$ there was a small decrease in the average particle size at about the same porosity of the functional layers (Table 2). The thickness of LNF collector layer after 
$10^{\mathrm{TH}}$ INTERNATIONAL CONFERENCE ON SUSTAINABLE ENERGY AND ENVIRONMENTAL 17 Protection (June $27^{\mathrm{TH}}-30^{\mathrm{TH}}, 2017$, Bled, Slovenia), ENERGy Storage

E. Pikalova, N. Bogdanovich, A. Kolchugin, D. Medvedev, L. Vedmid, S. Pikalov \& S. Plaksin: Development of $\mathrm{Pr}_{2}-\mathrm{XCaxNiO}_{4}$ Cathode Materials for It-Sofcs Based on Oxygen-Ion and Proton-Conduting Solid State Electrolytes

sintering at $1050^{\circ} \mathrm{C}$ was $50(5) \mu \mathrm{m}$, with porosity of $60(4) \%$ and the average size of particles of 2.3(3) $\mu \mathrm{m}$.

Table 2. Characterization of the PCNO functional layers

\begin{tabular}{|c|c|c|c|}
\hline $\begin{array}{c}\text { Functional } \\
\text { layer }\end{array}$ & $\begin{array}{c}\text { Porosity } \\
\%\end{array}$ & $\begin{array}{c}\text { Thickness, } \\
\mu \mathrm{m}\end{array}$ & $\begin{array}{c}\text { Average } \\
\text { particle } \\
\text { size, } \mu \mathrm{m}\end{array}$ \\
\hline PCNO1 & $63(4)$ & $18(2)$ & $3.3(3)$ \\
\hline PCNO3 & $57(3)$ & $21(2)$ & $3.2(3)$ \\
\hline PCNO5 & $65(5)$ & $21(2)$ & $2.2(2)$ \\
\hline
\end{tabular}
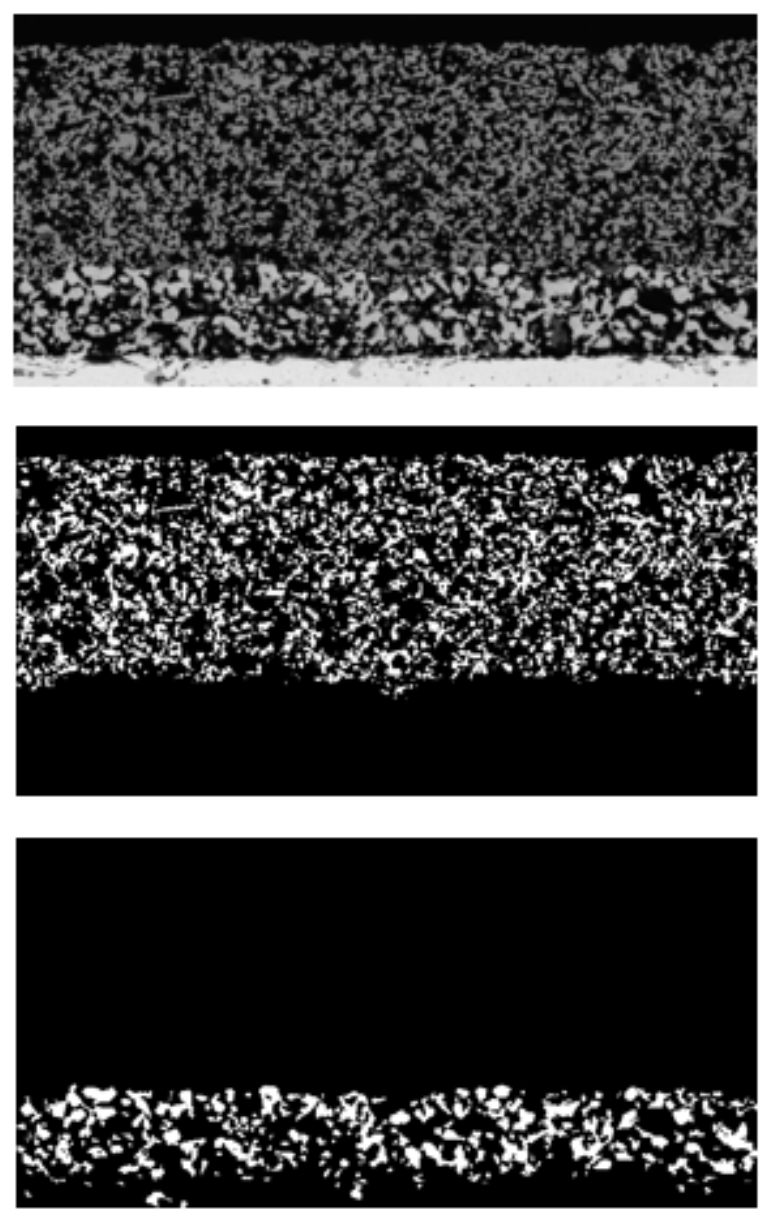

Figure 3. Microstructure of the electrode with the PNO functional and LNF collector layers (example of image sedimentation) 
$10^{\mathrm{TH}}$ InTERnATIONAL CONFERENCE ON Sustainable ENERgy AND ENVIRONMENTAL Protection (June 27 $7^{\mathrm{TH}}-30^{\mathrm{TH}}, 2017$, Bled, SLovenia), Hydrogen ANd Fuel Cells E. Pikalova, N. Bogdanovich, A. Kolchugin, D. Medvedev, L. Vedmid, S. Pikalov \& S. Plaksin: Development of $\mathrm{Pr}_{2}-\mathrm{XCaxNiO}_{4}$ Cathode Materials for It-Sofcs Based on Oxygen-Ion and Proton-Conduting Solid State Electrolytes

\section{Polarization resistance of $P C N O$ and PSNO electrodes}

Figure 4 depicts Arrhenius dependences of the polarization conductivity $\left(\sigma_{\eta}=1 / R_{\eta}\right)$ in dependence on the calcium content. Surprisingly, despite the higher conductivity of the Ca-substituted PNO, the polarization conductivity increases only for the electrodes with a small amount of calcium $(x=0.1-0.2)$. Further increasing $x$ results in a decrease in the polarization conductivity. Such a deterioration of the electrochemical activity of the electrodes may be connected with the reduction in the amount of interstitial oxygen and, as was shown in our work on $\mathrm{La}_{2-x} \mathrm{Ca}_{x} \mathrm{NiO}_{4+\delta}$ electrodes [11], subsequent reduction in the coefficients of oxygen surface exchange $\mathrm{k}^{*}$ and oxygen tracer diffusion $\mathrm{D}^{*}$, which may change the rate determining stages of the electrochemical reaction. Due to lower distortion induced by calcium doping into the PNO structure than that for LNO, it appears only at $x>0.2$.

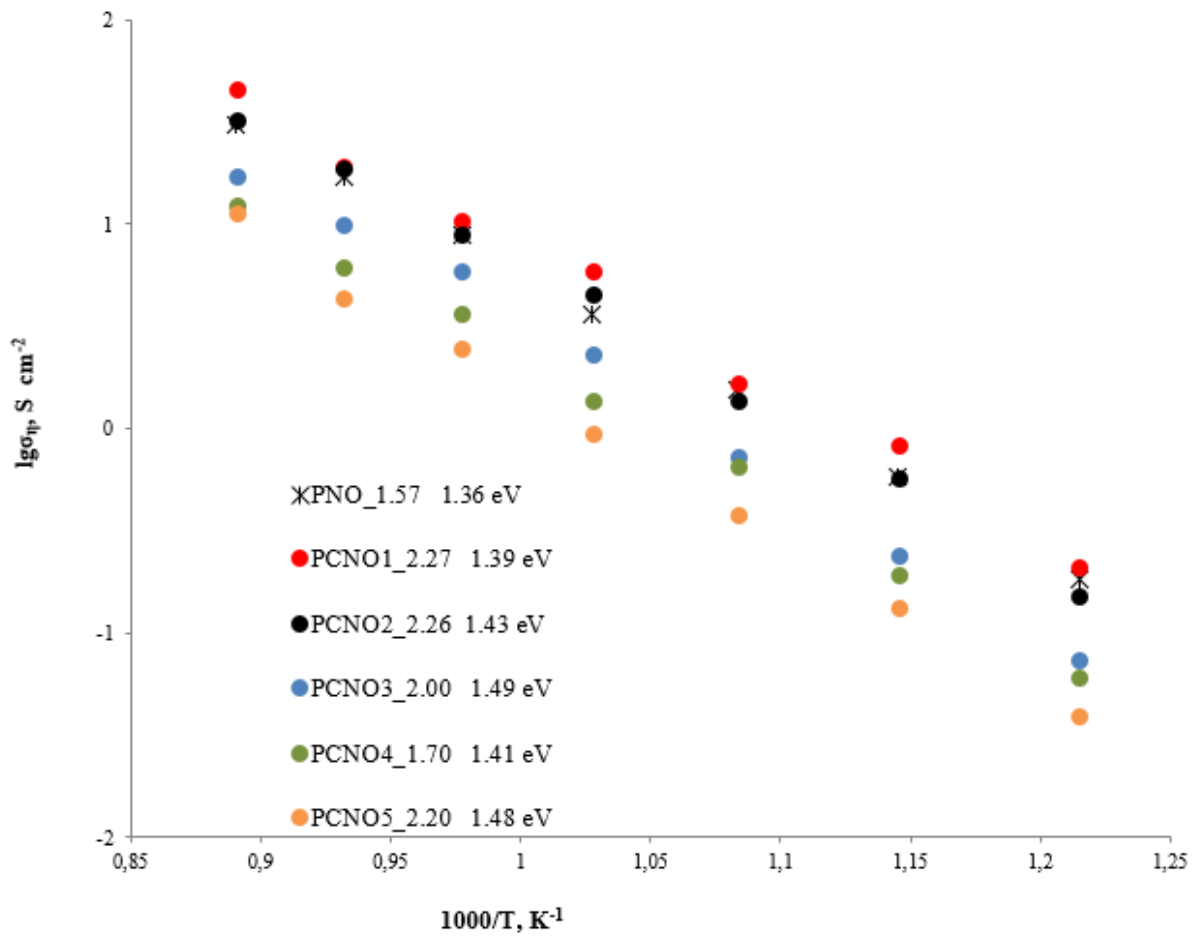

Figure 4. Polarization conductivity of the PCNO and PSNO electrodes sintered at $1200^{\circ} \mathrm{C}$ (related $\mathrm{S}_{\mathrm{BET}}$ of the electrode powders and $\mathrm{E}_{\mathrm{a}}$ of the polarization conductivity are shown)

In toto, PNO-based electrodes have higher polarization conductivity than that of LNObased electrodes [11]. The polarization resistance of the PCNO1, PCNO2 and PCNO3 
$10^{\mathrm{TH}}$ INTERNATIONAL CONFERENCE ON SUSTAINABLE ENERGY AND ENVIRONMENTAL Protection (June $27^{\mathrm{TH}}-30^{\mathrm{TH}}, 2017$, Bled, Slovenia), ENERGy Storage

E. Pikalova, N. Bogdanovich, A. Kolchugin, D. Medvedev, L. Vedmid, S. Pikalov \& S.

Plaksin: Development of $\mathrm{Pr}_{2}-\mathrm{XCaxNiO}_{4}$ Cathode Materials for It-Sofcs Based on Oxygen-Ion and Proton-Conduting Solid State Electrolytes

electrodes was $0.17,0.22$ and $0.44 \Omega \mathrm{cm}^{2}$ at $700^{\circ} \mathrm{C}$, respectively, which is lower than that of the PSNO3 electrode and LNO and LCNO3 electrodes with the same design 0.63 , and 0.50 and $4.01 \Omega \mathrm{cm}^{2}$, respectively. The two-layer, noble-metal free PCNO electrodes show superior performance, comparable to those Sr-substituted presented in literature. As for example, the best ASR values for PSNO electrodes in contact with $\mathrm{CeO}_{2}$-based electrolytes at $700^{\circ} \mathrm{C}$ were found $0.376 \Omega \mathrm{cm}^{2}(\mathrm{x}=0.8)$ [7] and $0.39 \Omega \mathrm{cm}^{2}(\mathrm{x}=0.7)$ [4].

\section{Polarization resistance of PCNO-SDC composite electrodes}

In undoped layered nickelates the ionic conductivity proceeds mainly by an interstitial conduction mechanism [12]. A decrease in oxygen excess will result in a decrease in the ionic conductivity. At the same time, the ionic conductivity, which occurs in the perovskite layers by a vacancy mechanism, will have an adequate level mainly at $\mathrm{x}>1.0$ [6]. The level of the overall ionic conductivity appears to reduce at the doping level of $0.3 \leq \mathrm{x} \leq 0.7$. It is known that increasing the electrochemical activity of the electrodes with a predominantly electronic or low ionic component of the mixed electronic conductivity is possible through the introduction of the ionic conductor. Indeed, introducing SDC in the electrodes we had a pronounced effect on the polarization conductivity of the PCNO electrodes with high calcium content (Figure 5). Note that the introduction of SDC into the PNO and PCNO1 electrode did not give such a positive effect on the electrochemical performance. This was probably due to a high inherent ionic conductivity, which is comparable with that in the electrolyte and increased interaction between electrolyte and electrode material with low calcium content. The lowest values of polarization resistance at $700^{\circ} \mathrm{C}$ in this work were observed for the PCNO1-SDC and PCNO3-SDC composite electrodes ( 0.25 and $0.28 \Omega \mathrm{cm}^{2}$, respectively). 
$10^{\text {TH }}$ International Conference on Sustainable Energy and Environmental Protection (June $27^{\mathrm{TH}}-30^{\mathrm{TH}}, 2017$, Bled, Slovenia), Hydrogen and Fuel Cells

E. Pikalova, N. Bogdanovich, A. Kolchugin, D. Medvedev, L. Vedmid, S. Pikalov \& S. Plaksin: Development of $\mathrm{Pr}_{2}-\mathrm{XCaxNiO}_{4}$ Cathode Materials for It-Sofcs Based on Oxygen-Ion and Proton-Conduting Solid State Electrolytes

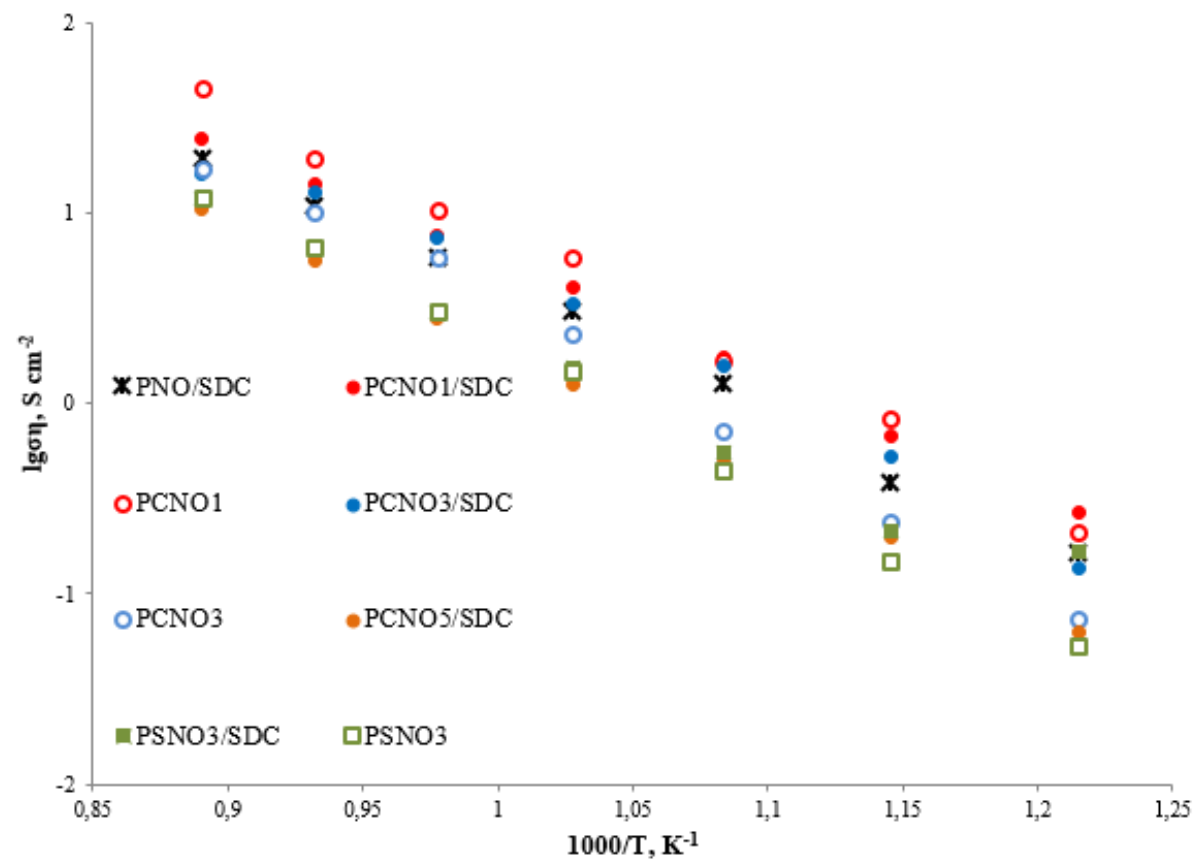

Figure 5. Polarization conductivity of the PCNO-SDC and PSNO-SDC electrodes sintered at $1200^{\circ} \mathrm{C}$

\subsection{Electrochemical activity of the composite electrodes in contact with the BCGCu proton conducting electrolyte}

The PCNO-BCGCu and PCNO-SDC composite electrodes studied demonstrated good matching with BCGCu electrolyte, whose thermal expansion coefficient (TEC) value is $10.5 \times 10^{-6} \mathrm{~K}^{-1}$ in the temperature range of $100-575^{\circ} \mathrm{C}$ and $8.65 \times 10^{-6} \mathrm{~K}^{-1}$ in the range of $575-900^{\circ} \mathrm{C}$, respectively [13]. The polarisation resistance of the PCNO3-BCGCu electrode was $0.26 \Omega \mathrm{cm}^{2}$ at $700^{\circ} \mathrm{C}$, which was lower than that of the PCNO1 composite electrode both with BCGCu and SDC electrolyte component $\left(0.53\right.$ and $0.46 \Omega \mathrm{cm}^{2}$, respectively). It can also be explained by the increased interaction between the composite electrode components during the electrode sintering at $1200^{\circ} \mathrm{C}$. However, in long term testing during $1500 \mathrm{~h}$ at a decreased temperature of $700^{\circ} \mathrm{C}$ we observed similar behaviour from both PCNO3-BCGCu and PCNO1-BCGCu electrodes (Figure 6). It shows that in the intermediate range of working temperatures both of the developed electrodes can be successfully function successfully; however, the first one is preferable due to its better thermal stability. Performance of the PCNO electrodes developed is significantly higher than those of the strontium and calcium substituted LNO electrodes [13]. 
E. Pikalova, N. Bogdanovich, A. Kolchugin, D. Medvedev, L. Vedmid, S. Pikalov \& S.

Plaksin: Development of $\mathrm{Pr}_{2}-\mathrm{XCaxNiO}_{4}$ Cathode Materials for It-Sofcs Based on Oxygen-Ion and Proton-Conduting Solid State Electrolytes

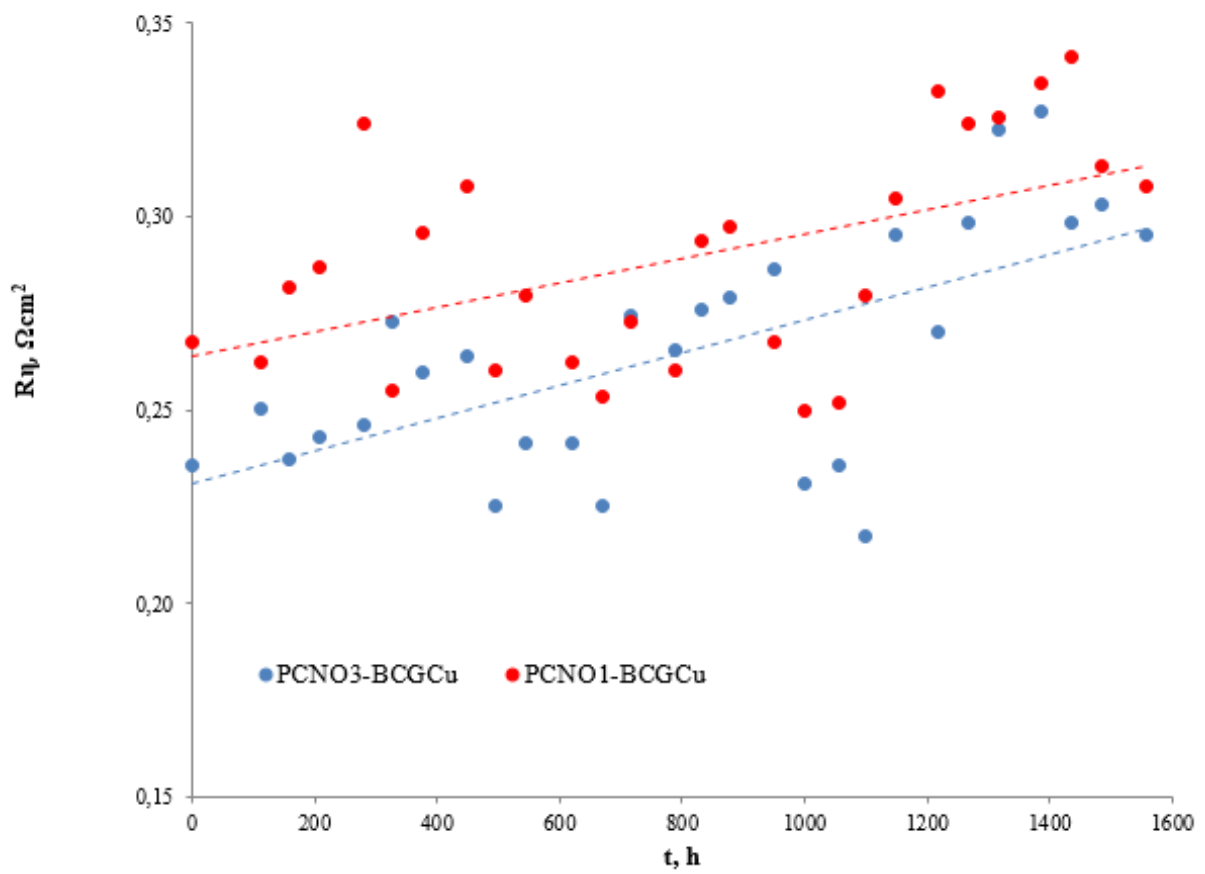

Figure 6. Time dependence of the polarization resistance of the composite electrodes in contact with BCGCu

\section{4}

\section{Conclusions}

$\operatorname{Pr}_{2-\mathrm{x}} \mathrm{Ca}_{\mathrm{x}} \mathrm{NiO}_{4+\delta}(\mathrm{x}=0.0-0.7)$ oxide materials were synthesized by a solid state reaction method. The obtained PCNO materials were single phase and at $\mathrm{x} \leq 0.3$ had orthorhombic structure related to a high content of interstitial oxygen $\delta$, and at $\mathrm{x}>4$ had tetragonal $\mathrm{P} 42 / \mathrm{ncm}$ structure. Doping with calcium increased thermal stability of PNO. It resulted also in the increased electrical conductivity due to increasing the concentration of electron holes caused by charge compensation from $\mathrm{Ca}^{2+}$ doping on $\mathrm{Pr}^{3+}$ site. The polarization conductivity of the electrodes in contact with the $\mathrm{Ce}_{0.8} \mathrm{Sm}_{0.2} \mathrm{O}_{2-\delta}$ electrolyte increased at $\mathrm{x} \leq 0.2$. At $\mathrm{x} \geq 0.3$ it decreased due to a remarkable $\delta$ decrease. Introducing $\mathrm{Ce}_{0.8} \mathrm{Sm}_{0.2} \mathrm{O}_{2-}$ $\delta$ into the electrodes with high calcium content had a pronounced positive effect on the polarization conductivity. Based on the study, electrochemically active and stable twolayer composite electrodes with $\operatorname{Pr}_{1.7} \mathrm{Ca}_{0.3} \mathrm{NiO}_{4+\delta}$-based functional layer and $\mathrm{LaNi}_{0.6} \mathrm{Fe}_{0.4} \mathrm{O}_{3-\delta}$ current collector were purposely proposed for use in IT-SOFCs with oxygen-ion $\mathrm{Ce}_{0.8} \mathrm{Sm}_{0.2} \mathrm{O}_{2-\delta}$ and proton-conducting $\mathrm{BaCe}_{0.8} \mathrm{Gd}_{0.19} \mathrm{Cu}_{0.01} \mathrm{O}_{3-\delta}$ electrolytes. 
$10^{\mathrm{TH}}$ International Conference on Sustainable Energy and Environmental Protection (June $27^{\mathrm{TH}}-30^{\mathrm{TH}}, 2017$, Bled, Slovenia), Hydrogen and Fuel Cells E. Pikalova, N. Bogdanovich, A. Kolchugin, D. Medvedev, L. Vedmid, S. Pikalov \& S. Plaksin: Development of $\mathrm{Pr}_{2}-\mathrm{XCaxNiO}_{4}$ Cathode Materials for It-Sofcs Based on Oxygen-Ion and Proton-Conduting Solid State Electrolytes

\section{Acknowledgements}

This work is financially supported by the Russian Foundation for Basic Research (grant no. 16-3300006), electrochemical study was partly supported by the Program of Fundamental Research of RAS (grant no. 15-20-3-15). The study was performed with using facilities of the shared access center (IHTE UB RAS) and "Ural-M" center (IMET UB RAS).

\section{References}

[1] P. Odier, C. Allançon, and J.M. Bassat, "Oxygen Exchange in $\mathrm{Pr}_{2} \mathrm{NiO}_{4}$ as high temperature and direct formation of $\mathrm{Pr}_{4} \mathrm{Ni}_{3} \mathrm{O}_{10-x}$," J. Solid State Chem., vol. 153, pp. 381-385, Sept. 2012.

[2] A.-V. Kovalevsky, V.V. Khartom, A.A. Yaremchenko, Y.V. Pivak, E.N. Naumovich, and J.R Frade, "Stability and oxygen transport properties of $\mathrm{Pr}_{2} \mathrm{NiO}_{4+\delta}$ ceramics," J. Europ. Ceram. Soc, vol. 27, pp. 4269-4279, March 2007.

[3] V. Vashook, E. Girdauskaite, J. Zosel, T.-L. Wen, H. Ullmann and U. Guth, "Oxygen nonstoichiometry and electrical conductivity of $\operatorname{Pr}_{2-\mathrm{x}} \mathrm{Sr}_{\mathrm{x}} \mathrm{NiO}_{4 \pm \delta}$ with $\mathrm{x}=0-0.5$," Solid State Ionics, vol. 177, pp. 90-96, May 2006.

[4] S.S. Bhoga, A.P. Khandale and B.S. Pahune, "Investigation on $\operatorname{Pr}_{2-x} \mathrm{Sr}_{x} \mathrm{NiO}_{4+\delta}(\mathrm{x}=0.3-1.0)$ cathode materials for intermediate temperature solid oxide fuel cell," Solid State Ionics, vol. 262, pp. 340-344, Sept. 2014.

[5] R.K. Sharma, S._k Cheah, M. Burriel, L. Dessemond, J.-M. Bassat, and E. Djurado, "Design of $\mathrm{La}_{2-\mathrm{x}} \mathrm{Pr}_{\mathrm{x}} \mathrm{NiO}_{4+\delta}$ SOFC cathodes: a compromise between electrochemical performance and thermodynamic stability," J. Mat. Chem. A, vol. 5, pp. 1120-1132, Dec. 2016.

[6] E. Kravchenko, K. Zakharchuk, A.Viskup, J. Grins, G. Svensson, V. Pankov, and A. Yaremchenko, "Impact of oxygen defiency on the electrochemical high performance of $\mathrm{K}_{2} \mathrm{NiF}_{4}$-type ( $\left.\mathrm{La}_{1-\mathrm{x}} \mathrm{Sr}_{\mathrm{x}}\right)_{2} \mathrm{NiO}_{4-\delta}$ oxygen electrodes," ChemSucChem, vol. 10, pp. 600-611, Dec. 2016.

[7] J. Yang, J. Cheng, Q. Jiang, Y. Wang, R. Wang, and J. Gao, "Preparation and electrochemical properties of strontium doped $\mathrm{Pr}_{2} \mathrm{NiO}_{4+\delta}$ cathode materials for intermediate-temperature solid oxide fuel cells", Int. J. Hydrog. Energy, vol. 37 pp. 17461751, Nov. 2012.

[8] E.Yu. Pikalova, D.A. Medvedev, and A.F. Khasanov, "Structure, stability and thermomechanical properties of Ca-substituted $\operatorname{Pr}_{2} \mathrm{NiO}_{4+\delta}$ ", Physics of the Solid State, vol. 59, pp. 694-702, July 2016.

[9] K. Ruck, G. Krabbes, and I. Vogel, "Structural and electrical properties of $\mathrm{La}_{2-\mathrm{x}} \mathrm{Ca}_{x} \mathrm{NiO}_{4+\delta}$ in regard to the oxygen content $\delta$ ", Mat. Res. Bull., vol. 34, pp. 1689-1697, Nov. 1998.

[10] E.Yu. Pikalova, N.M. Bogdanovicha, A.A. Kolchugin, M.V. Ananyev, and A.A. Pankratov, "Influence of the synthesis method on the electrochemical properties of bilayer electrodes based on $\mathrm{La}_{2} \mathrm{NiO}_{4}+\delta$ and $\mathrm{LaNi}_{0.6} \mathrm{Fe}_{0.4} \mathrm{O}_{3}-\delta$ ", Solid State Ionics, vol. 288, pp. 3632, May 2016.

[11] A.A. Kolchugin, E.Yu. Pikalova, N.M. Bogdanovich, D.I. Bronin, S.M. Pikalov, S.V. Plaksin, M.V. Ananyev and V.A. Eremin, "Structural, electrical and electrochemical properties of calcium-doped lanthanum nickelate", Solid State Ionics, vol. 288, pp. 48-53, May 2016.

[12] L. Minervini, R.W. Grimes, J.A. Kilner, and K.E. Sickafus, "Oxygen migration in $\mathrm{La}_{2} \mathrm{NiO}_{4+\delta}$ ”, J. Mater. Chem., vol. 10, pp. 2349-2354, Aug. 2000. 
$10^{\mathrm{TH}}$ INTERNATIONAL CONFERENCE ON SUSTAINABLE ENERGY AND ENVIRONMENTAL 23 Protection (June $27^{\mathrm{TH}}-30^{\mathrm{TH}}, 2017$, Bled, Slovenia), EnERgy Storage E. Pikalova, N. Bogdanovich, A. Kolchugin, D. Medvedev, L. Vedmid, S. Pikalov \& S. Plaksin: Development of $\mathrm{Pr}_{2}-\mathrm{XCaxNiO}_{4}$ Cathode Materials for It-Sofcs Based on Oxygen-Ion and Proton-Conduting Solid State Electrolytes

[13] E. Yu. Pikalova, N. M. Bogdanovich, A. A. Kolchugin, A. Brouzgou, D. I. Bronin, S.V. Plaksin, A. F. Khasanov, P. Tsiakaras "Effect of Nature of the Ceramic Component of the Composite Electrodes Based on $\mathrm{La}_{1.7} \mathrm{Ca}(\mathrm{Sr})_{0.3} \mathrm{NiO}_{4+\delta}$ on their Electrochemical Performance", ECS Transactions, vol. 68, pp. 809-815, July 2015. 
$24 \quad 10^{\mathrm{TH}}$ International Conference on Sustainable EnERgy AND ENVIRONMENTAL Protection (June $27^{\mathrm{TH}}-30^{\mathrm{TH}}, 2017$, Bled, Slovenia), Hydrogen And Fuel Cells 
$10^{\mathrm{TH}}$ INTERNATIONAL CONFERENCE ON Sustainable ENERgy AND ENVIRONMENTAL Protection (June $27^{\mathrm{TH}}-30^{\mathrm{TH}}$, 2017, Bled, Slovenia), Hydrogen AND Fuel Cells

J. Krope, A.Ghani Olabi, D. Goričanec \& S. Božičnik

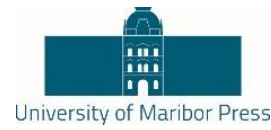

\title{
Experimental Study of Operational Parameters on the Performance of PEMFCS in Dead end Mode
}

\author{
TABBi WILBERFORCE, FAWWAD NiSAR KHATIB, OGUNGBEMI EMMANUEL, OLUWATOSIN \\ IJEAODOla, A. ABDUlRaHman, AHMED Al MAKKy AHMAD BAROUTAJi \& ABDUl \\ GHANI OLABI
}

\begin{abstract}
The general performance of fuel cell is influenced by parameters such as cell operating temperature, humidification and even the pressure of the hydrogen gas. The performance of proton exchange membrane fuel cell was carefully studied through experimental and mathematical analysis using polarization curves. The work concluded that increasing the pressure of the hydrogen gas increased the cell voltage, hence increasing the output power of the fuel cell. The cell operating temperature was studied in relation to the fuel cell performance. It was observed that the performance of the fuel cell increased from room temperature of $18 \mathrm{oC}$ to $47 \mathrm{oC}$. Above $55 \mathrm{oC}$ the performance begins to drop due to the drying up of the membrane causing an increase in the ionic resistance. The temperature of the humidification chamber was increased gradually from $20 \mathrm{oC}$ to $90 \mathrm{oC}$ to see the effect it will have on the fuel cell at such high operating temperature above 55oC. It was observed that at higher humidification temperature and higher cell temperature, the fuel cell was able to perform better since the membrane became moist increasing the proton conductivity through the electrolyte. The losses that also occur in the fuel cell were also critically analysed for each operating parameter.
\end{abstract}

Keywords: • PEM fuel cell • Polarization curves • Losses • Hydrogen • Humidification •

\begin{abstract}
CORRESPONDENCE ADDRESS: Tabbi Wilberforce, University of the West of Scotland, Institute of Engineering and Energy Technologies, High St, Paisley PA1 2BE, United Kingdom, e-mail: B00281710@studentmail.uws.ac.uk. Fawwad Nisar Khatib, University of the West of Scotland, Institute of Engineering and Energy Technologies, High St, Paisley PA1 2BE, United Kingdom, email: Fawwad.Nisar@uws.ac.uk. Ogungbemi Emmanuel, University of the West of Scotland, UK, Institute of Engineering and Energy Technologies, High St, Paisley PA1 2BE, United Kingdom, e-mail, bunmieogungbemi@yahoo.com, Oluwatosin Ijeaodola, University of the West of Scotland, UK, Institute of Engineering and Energy Technologies, High St, Paisley PA1 2BE, United Kingdom, e-mail Oluwatosin.Ijaodola@uws.ac.uk. A. Abdulrahman, University of the West of Scotland, UK, Institute of Engineering and Energy Technologies, High St, Paisley PA1 2BE, United Kingdom, e-mail: B00292963@studentmail.uws.ac.uk. Ahmed Al Makky PhD, University of the West of Scotland, Institute of Engineering and Energy Technologies, High St, Paisley PA1 2BE, United Kingdom, e-mail: Ahmed.AlMakky@uws.ac.uk. Ahmad Baroutaji PhD, Cork Institute of Technology, Department of Process, Energy and Transport Engineering, Rossa Ave, Bishopstown, Cork, Ireland, email: ahmad.baroutaji2@mail.dcu.ie. Abdul Ghani Olabi, Professor, University of the West of Scotland, UK, Institute of Engineering and Energy Technologies, High St, Paisley PA1 2BE, United Kingdom, email: Abdul.Olabi@uws.ac.uk.
\end{abstract}

https://doi.org/10.18690/978-961-286-054-7.3

ISBN 978-961-286-054-7

(C) 2017 University of Maribor Press

Available at: http://press.um.si. 
$10^{\mathrm{TH}}$ INTERNATIONAL CONFERENCE ON Sustainable ENERGy AND ENVIRONMENTAL Protection (June $27^{\mathrm{TH}}-30^{\mathrm{TH}}, 2017$, Bled, Slovenia), Hydrogen and Fuel Cells T.Wilberforce, F. N. Khatib, O. Emmanuel, O. Ijeaodola, A. Abdulrahman, A. Al Makky, A. Baroutaji \& A.G. Olabi: Experimental Study of Operational Parameters on the Performance of PEMFCS in Dead end Mode

The current movement towards environmentally friendlier and more efficient power production has caused an increased interest in alternative fuels and power sources. Fuel cells are one of the oldest energy conversion technologies but lately they are being investigated properly for commercial purposes [1-3]. Burning of fossil fuel leads to air pollution which is hazardous to the health and leads to the depletion of the ozone layer affecting the climatic conditions in the world [4]. A fuel cell is an electrochemical device that transforms energy in fuel directly into electricity. Fuel cells have several advantages, some of these advantages are: they have the potential for a high operating efficiency which is a strong function of the size of the fuel cell, they also have scalable design, fuel cell produce zero greenhouse emissions, again they have no moving parts hence there is no wear and tear and finally fuel cells can provide instantaneous recharge compared to batteries [4-8]. There are still some limitations of fuel cells in terms of cost. The performance of the fuel cells is highly dependent on the purity of the gas being used. An acceptable way of determining the performance of PEM fuel cell is through polarization curves. Three main phenomenon occur during the general operation of a fuel cell [9]. This leads to the creation of three main regions on the curve that is the electrode kinetics, ohmic losses and transport limitations [10]. The steps leading to the adsorption of the reactants species, transfer of electrons across the double layer, desorption of the reactant species, the number and distribution of active sites and the general nature of the surface of the electrodes creates the first region called the activation polarization. There is a direct variation between current and ohmic loss which is the second region on the polarization curve. The ohmic loss increases as the current density increases [10]

The ohmic losses often experienced in fuel cells can be curbed using a thinner electrolyte membrane with good humidification, better conductivity cell stack materials, proper and better flow field design and current collectors. Reducing the contact resistances at various interfaces is also another pragmatic way of reducing ohmic losses [11]. The mass transport limitations to reactants and products to or from the electro reactive sites create concentration losses. These voltage losses occur throughout the current density but are usually seen at very high current densities where the supply of reactants becomes a challenge [12]. A recommended approach of improving the performance of fuel cell is by increasing the operating temperature. When the cell operating temperature is high the rate of reaction is faster hence more electrons will be released thus providing an effective water management through the cell [13]. High relative humidity is required especially if the cell is operating at a higher temperature. Hydration of the membrane is another important issue that determines the general performance of the membrane and its durability. In situations where the hydration of the membrane is low, there is higher ionic resistance and can even destroy the membrane. This work explores the operating parameters that affect the performance of fuel cell stack. The fuel cell is operated in a dead end mode and the hydrogen outlet is blocked in order to pressurize the anode [14]. 


\section{Mathematical Modelling of PEM Fuel Cell.}

The mathematical model is developed to describe the fundamental electrochemical transport phenomena and charge transport through the cell. It is equally possible to predict the performance of the fuel cell through mathematical modelling under different operating conditions and optimize the design of fuel cell system.

\subsection{Thermodynamic performance of fuel cell}

The hydrogen on reaching the electrolyte splits into hydrogen ions and electrons [13-14] according to equation (1).

$2 \mathrm{H}_{2(g)} \longrightarrow 4 \mathrm{H}^{+}+4 \mathrm{e}^{-}$

The electrons then flow through an external load producing electricity. Electrical work is done as the electrons flow through the load and finally return to the cathode. The protons (hydrogen ions) then flow through the membrane to the electrolyte cathode interface where the meet with the oxygen and electrons to produce water and heat as by product [15]. The entire reaction process is as indicated in equation (2).

$4 H^{+}+4 e^{-}+O_{2(g)} \rightarrow 2 H_{2} \mathrm{O}_{(1)}$

The entire electrochemical reaction can be represented by equation (3).

$2 \mathrm{H}_{2(g)}+\mathrm{O}_{2(g)} \longrightarrow 2 \mathrm{H}_{2} \mathrm{O}_{(l)}$

The maximum electrical energy output and the potential difference between the cathode and anode are achieved when the fuel cell is operated under thermodynamically reversible conditions. The reversible cell potential is the maximum possible cell potential. At any current density, the net output voltage of the fuel cell is the reversible cell potential minus the irreversible potential [16].

$V(i)=V_{\text {rev }}-V_{\text {irrev }}$

But $V_{\text {rev }}=E_{r}$ is the maximum (reversible) voltage of the fuel cell and $V_{\text {irrev }}$ is the irreversible voltage loss (over potential) occurring at the cell. The maximum electrical work $\left(\mathrm{W}_{\text {elec }}\right)$ any system can perform at a constant temperature and pressure is determined by the negative change in Gibbs free energy change $(-\Delta G)$ [17], hence the maximum electrical work is shown in equation 5

$\mathrm{W}_{\text {elect }}=-\Delta \mathrm{G}$

$\mathrm{W}_{\text {elect }}=\Delta \mathrm{G}=\Delta \mathrm{H}-\mathrm{T} \Delta \mathrm{S}$ 
$10^{\mathrm{TH}}$ InTERnAtional CONFERENCE ON Sustainable ENERgy AND ENVIRONMENTAL Protection (June $27^{\mathrm{TH}}-30^{\mathrm{TH}}, 2017$, Bled, Slovenia), Hydrogen And Fuel Cells

T.Wilberforce, F. N. Khatib, O. Emmanuel, O. Ijeaodola, A. Abdulrahman, A. Al Makky, A. Baroutaji \& A.G. Olabi: Experimental Study of Operational Parameters on the Performance of PEMFCS in Dead end Mode

Where $\mathrm{G}$ is the Gibbs free energy, $\mathrm{H}$ is the Enthalpy of formation and $\mathrm{S}$ is the Entropy. The change in enthalpy of formation for any chemical process can also be expressed from the heat and energy balance as shown in equation (7)

$\Delta \mathrm{H}=\sum m_{i} h_{i}-\sum m_{j} h_{j}$

Where $\sum m_{i} h_{i}$ is the mass times the enthalpy of each substance leaving the system. $\sum m_{j} h_{j}$ is the mass times the enthalpy of each substance entering the system. The possibility of a system performing an electrical work by a charge, $\mathrm{Q}$ (coulombs) by an electrical potential difference, E [18-20] in volts shown in equation (8).

$\mathrm{W}_{\text {elec }}=\mathrm{EQ}$

But the charge $\mathrm{Q}=\mathrm{nF}$

Where: $\mathrm{Q}=$ Charge, $\mathrm{n}$ is the number of moles of electrons, $\mathrm{F}$ is the Faradays constant ( 96,485 coulombs per mole of electrons), hence,

$\Delta \mathrm{G}=-n \mathrm{nE}_{\mathrm{r}}$

$\mathrm{E}_{\mathrm{r}}=-\frac{\Delta \mathrm{G}_{r x n}}{n F}=-\frac{\Delta \mathrm{H}-\mathrm{T} \Delta \mathrm{S}}{n F}$

\subsection{Fuel cell performance}

The performance of a fuel cell as explained is determined by the graph of the output voltage $(\mathrm{V})$ against the current or current density $\left(\mathrm{A} / \mathrm{cm}^{2}\right)$. The graph is also referred to as the I-V or polarization curve which is effectively used for the design and optimization of fuel cells [18]. The theoretical voltage of any fuel cell can be determined thermodynamically depending on the temperature, pressure and set of species. The actual voltage from the fuel cell is always less due to losses as explained in equation 4 . The losses turn to increase as more current is being generated from the fuel cell [19]. The fuel cell voltage output can be described therefore by equation (11).

$\mathrm{V}=E_{\text {thermo }}-\left(\eta_{\text {act }, a}+\eta_{\text {act }, c}\right)-\eta_{\text {ohmic }}-\eta_{\text {conc }, a}+\eta_{\text {con }, c}$

Where $\mathrm{V}$ is the real output voltage, $\mathrm{E}_{\text {thermo }}$ is the thermodynamically predicted voltage, $\eta_{a c t, a}$ is the anode activation polarization due to reaction kinetics $\eta_{a c t, c}$ is the cathode activation polarization due to reaction kinetics, $\eta_{c o n c, a}$ is the anode concentration losses due to mass transport, $\eta_{c o n, c}$ is the cathode concentration losses due to mass transport $\eta_{\text {ohmic }}$ is the ohmic loss due to ionic and electrical resistances. $E_{\text {thermo }}$ can be determined mathematically using the Nernst equation which factors the operating temperature and pressure into consideration [19]. 
$10^{\mathrm{TH}}$ INTERNATIONAL CONFERENCE ON SUSTAINABLE ENERGY AND ENVIRONMENTAL Protection (June $27^{\mathrm{TH}}-30^{\mathrm{TH}}, 2017$, Bled, Slovenia), ENERGy Storage

T.Wilberforce, F. N. Khatib, O. Emmanuel, O. Ijeaodola, A. Abdulrahman, A. Al Makky, A. Baroutaji \& A.G. Olabi: Experimental Study of Operational Parameters on the Performance of PEMFCS in Dead end Mode

$E_{\text {thermo }}=E^{O}-\frac{R T}{n F} \ln \left[\frac{a_{H 2 O}}{a_{H 2} a_{O 2}^{1 / 2}}\right]$

Where $E^{O}$ is the Standard state reversible voltage, $\mathrm{R}$ is the universal gas constant, $\mathrm{T}$ is the fuel cell Temperature, $\mathrm{n}$ is the number of electrons transferred in the reaction, $\mathrm{F}$ is the Faraday's constant, $a_{\mathrm{H} 2 \mathrm{O}}=$ activities of water, $a_{\mathrm{H} 2}=$ activities of hydrogen $a_{\mathrm{O} 2}$ is activities of oxygen.

Using the Butler - Volmer equation, the activation polarization $\left(\eta_{a c t, a}+\eta_{a c t, c}\right)$ can be derived. The Tafel slope equation is used in situations of slow electrode reaction kinetics [20] and large current being drawn from the fuel cell.

$\eta_{a c t}=\mathrm{a}+\mathrm{b} \operatorname{In}(\mathrm{i})$

Where $\mathrm{a}=-\frac{R T}{\alpha n F} \ln \left(i_{o}\right)$

$\mathrm{b}=\frac{R T}{\alpha n F}$

But $i_{o}$ is the exchange current density which is the rate of forward and backward reaction at equilibrium. $\alpha$ is a parameter related to electrode kinetics or the transfer coefficient. The ohmic loss or resistance complies to ohms law. It occurs as a result to resistance due to the transfer of hydrogen ions(protons) and electrons with the PEM fuel cell. It is expressed as:

$\eta_{\text {ohmic }}=\mathrm{i} \cdot R_{\text {ohmic }}=\mathrm{i} .\left(R_{\text {ionic }}+R_{\text {electronic }}\right)$

Where $R_{\text {ohmic }}$ is the total internal cell resistance, $R_{\text {ionic }}$ is the resistance to ion transport within the membrane and $R_{\text {electronic }}$ is the resistance to electron transport in the electron conductive parts [17].

The concentration losses or over-potential occurs due to the reactants and products concentration gradient. It could also be explained as the loss due to the consumption of the reactant at the surface of electrode causing concentration gradient to develop between the bulk and electrode surface. A practical scenario in the fuel cell is that the concentration of oxygen in the flow channel at the cathode region is always higher compared to that in the catalyst active site [20]. This difference tends to increase as more current is drawn from the fuel cell. A critical stage occurs with time where the concentration of the oxygen in the catalyst active site falls to zero. The current generated at this stage is called the limiting current density $\left(i_{L}\right)$. The maximum current that can be drawn from the fuel cell is the limiting current density. There is depletion of reactants and product accumulation which eventually reduces the cell voltage due to two major reasons: reduction in the thermodynamic cell voltage (lower $E_{\text {thermo }}$ ) and a reduction in 
$10^{\mathrm{TH}}$ InTERnAtional CONFERENCE ON Sustainable ENERgy AND ENVIRONMENTAL Protection (June $27^{\mathrm{TH}}-30^{\mathrm{TH}}, 2017$, Bled, Slovenia), Hydrogen and Fuel Cells

T.Wilberforce, F. N. Khatib, O. Emmanuel, O. Ijeaodola, A. Abdulrahman, A. Al Makky, A. Baroutaji \& A.G. Olabi: Experimental Study of Operational Parameters on the Performance of PEMFCS in Dead end Mode

the rate of reaction (higher $\eta_{a c t}$ ) [18]. Concentration loss therefore can represented by equation (17).

$\eta_{\text {con }}=\frac{R T}{n F} \operatorname{In}\left[\frac{i_{L}}{i_{L}-i}\right]$

The activation polarization occurring at the anode in PEM fuel cells with hydrogen and air as the reactive substances is negligible compared to the activation polarization at the cathode. This is basically due to the oxygen reduction half - reaction being slower in kinetics compared to the hydrogen oxidation half - reaction. The limitations due to mass transport of oxygen are more severe because air is being utilized instead of pure oxygen and also the diffusion rate of $\mathrm{O}_{2}$ is slower compared to $\mathrm{H}_{2}$ [19]. The entire cell reaction is shown in equation (18).

$\mathrm{V}=E_{\text {thermo }}-\eta_{\text {act }, c}-\eta_{\text {ohmic }}-\eta_{\text {con }, c}$

Equation 18 can further be expanded to equation 19 as the formulae to determine the cell voltage

$\mathrm{V}=E_{\text {thermo }}-\left[\mathrm{a}_{\mathrm{C}}+\mathrm{b}_{\mathrm{C}} \operatorname{In}\left(\mathrm{i}+\mathrm{i}_{\text {loss }}\right)\right]-\left[\mathrm{i} . R_{\text {ohmic }}\right]-\mathrm{C}_{\mathrm{C}} \operatorname{In}\left[\frac{i_{L c}}{i_{L C}-\left(i+i_{\text {loss }}\right.}\right]$

\section{Experimental Set Up}

The paper intends to investigate the operating parameters affecting the performance of PEM fuel cell such as operating pressures, relative humidity of hydrogen and the oxidant stoichiometric ratio. The fuel cell used is a five cell stack PEM fuel cell made of Nafion212 membrane and having an active surface area of $11.4 \mathrm{~cm}^{2}$. The thickness of the membrane is nearly $27 \mu \mathrm{m}$ and the electrodes are platinum loaded with $0.3 \mathrm{mg} \mathrm{Pt} / \mathrm{cm}^{2}$.

The fuel cell stack was operated using pure hydrogen $(99.999 \mathrm{vol} \%)$ and air without humidification. The hydrogen was supplied at varying pressures from 1,1.5,2,2.5bar and the flow rate was measured using a digital hydrogen flow meter. The hydrogen was supplied in a dead-end mode as shown in Figure 3. The outlet of the anode region was closed in order to keep the hydrogen gas pressurized but a valve was attached to open occasionally to allow any water built up to leave the cell.

The schematic drawing of the experimental set up is shown in Figure 1. 

Protection (June $27^{\mathrm{TH}}-30^{\mathrm{TH}}, 2017$, Bled, SLovenia), EnERgy Storage

T.Wilberforce, F. N. Khatib, O. Emmanuel, O. Ijeaodola, A. Abdulrahman, A. Al Makky, A. Baroutaji \& A.G. Olabi: Experimental Study of Operational Parameters on the Performance of PEMFCS in Dead end Mode

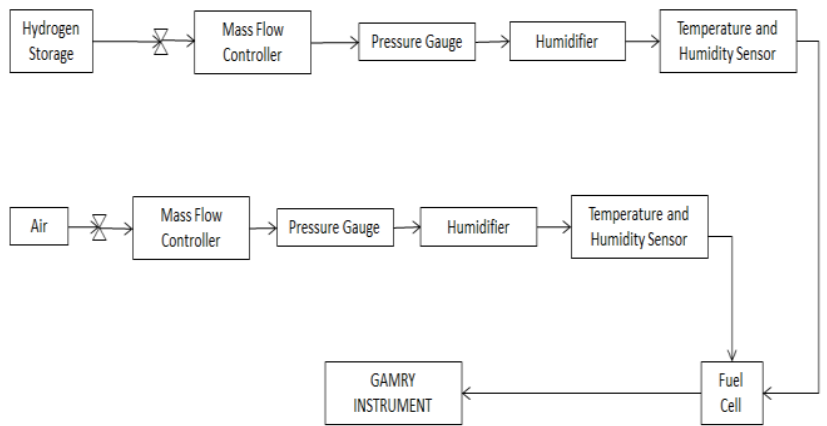

Figure 1: Schematic drawing of the fuel cell testing set up

\section{Results and Discussion}

The experimental results obtained were first fit with a model designed in Matlab. This was done to carry out an exhaustive analysis on the fuel cell without carrying out further experiments. The experiment was initially performed at a constant pressure and temperature of $25^{\circ} \mathrm{C}$. It can be seen in Figure 2 that the model shows a good fit with the experimental results.

\section{Effect of Operating Pressure on the Fuel Cell Performance.}

As discussed earlier, each experiment was performed 5 times and for the first experiment, the air pressure was kept at constant pressure of 1 bar while the fuel pressure was varied between 1 and 2.5bar. This was done to explore the effect of this operating condition on the performance of the fuel cell.

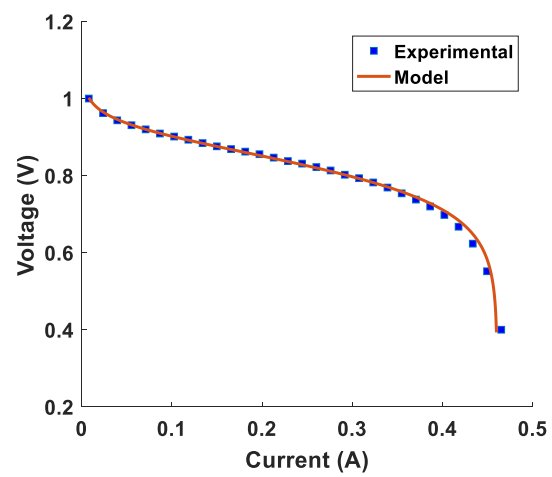

Figure 2: Polarization curve at hydrogen pressure of 2.5 bar.

From the polarization curve in Figure 3, it was observed that the open circuit voltage increased appreciably as the hydrogen fuel pressure increased. The operational 
$10^{\mathrm{TH}}$ International Conference on Sustainable Energy and Environmental Protection (June $27^{\mathrm{TH}}-30^{\mathrm{TH}}, 2017$, Bled, Slovenia), Hydrogen and Fuel Cells

T.Wilberforce, F. N. Khatib, O. Emmanuel, O. Ijeaodola, A. Abdulrahman, A. Al Makky, A. Baroutaji \& A.G. Olabi: Experimental Study of Operational Parameters on the Performance of PEMFCS in Dead end Mode

temperature was maintained at $25.5^{\circ} \mathrm{C}$. The maximum current obtained from the fuel cell was $600 \mathrm{~mA}$. This current was noticed to be constant throughout the changes made in the fuel pressure.

The same experiment was conducted for the fuel cell just like experiment 1 but in this instance the hydrogen pressure was kept constant but the air pressure was initially reduced to a pressure of 1 bar and later increased to 2.5 bar. At a low air pressure, the performance of the fuel cell reduced as less current was being generated from the cell. The maximum current that was generated was $600 \mathrm{~mA}$ while the voltage equally reduced.

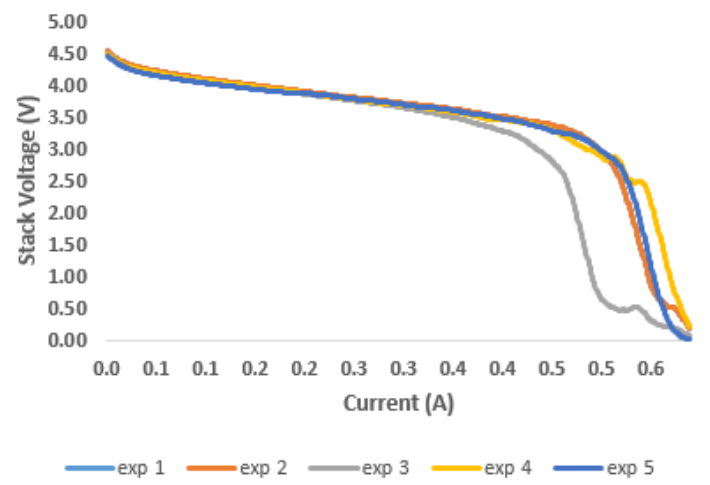

Figure 3: Polarization curve for fuel cell showing the open circuit voltage

\subsection{Effect of operating temperature on the fuel cell.}

The fuel cell stack performance was first analysed by varying the operational cell temperature between $18^{\circ} \mathrm{C}$ and $65^{\circ} \mathrm{C}$. The fuel pressure and flow rate was kept constant and the oxygen or air pressure and flow rate were also maintained.

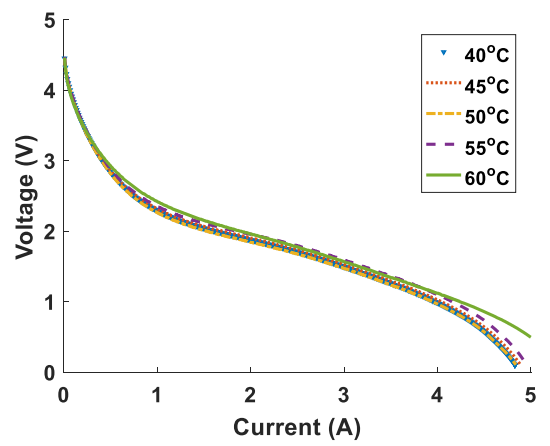

Figure 4: Cell operating temperature with respect to current and voltage. 
It was noticed that an increase in cell operating temperature significantly increased the performance of the fuel cell due to an increase in rate of reaction. The current being generated from the fuel cell increased to $5.2 \mathrm{~A}$ at a temperature of $55^{\circ} \mathrm{C}$ and the open circuit voltage equally increased to $4.6 \mathrm{~V}$ at that same operating condition as shown in Figure 4. It was also observed from Figure 4 that the fuel cell temperature often increase to a specific range and fall back to a low temperature. This was because as more current was being produced, the fuel cell was equally generating more water which eventually tends to reduce the internal temperature of the fuel cell. Another reason that could be attributed to the high performance of the fuel cell at high temperature was an increase in diffusivity at these conditions. Nafion membranes becomes more conductive at higher temperatures generating more current from the fuel cell. The increase in temperature also increase exchange current density which reduces the activation polarization.

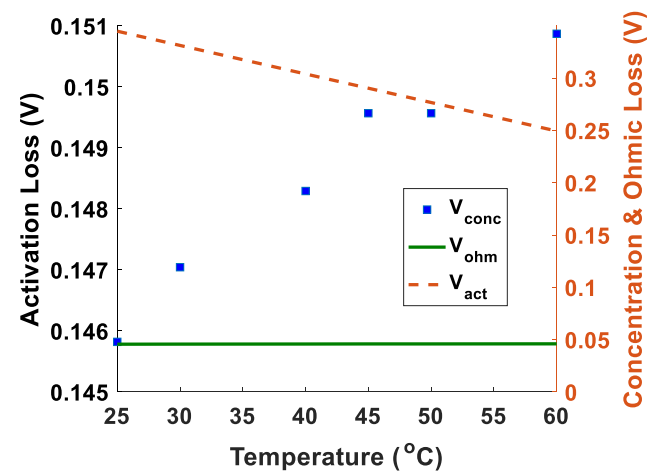

Figure 5: Loss characteristics at maximum power over a range of increasing cell temperature

Figure 5 shows the various losses between minimum temperatures and high temperatures of $25^{\circ} \mathrm{C}$ to $60^{\circ} \mathrm{C}$. It can be clearly seen that activation polarization decreased with increased cell operating temperature but the ohmic loss was constant at the maximum power. Concentration loss also increased with respect to temperature.

Figure 6 shows the maximum achievable power from the fuel cell with respect to temperature. Increasing the cell operating temperature increased the maximum achievable stack power to nearly $4.8 \mathrm{~W}$. 
$10^{\mathrm{TH}}$ International Conference on Sustainable Energy and Environmental Protection (June 27 $7^{\mathrm{TH}}-30^{\mathrm{TH}}, 2017$, Bled, Slovenia), Hydrogen And Fuel Cells

T.Wilberforce, F. N. Khatib, O. Emmanuel, O. Ijeaodola, A. Abdulrahman, A. Al Makky, A. Baroutaji \& A.G. Olabi: Experimental Study of Operational Parameters on the Performance of PEMFCS in Dead end Mode

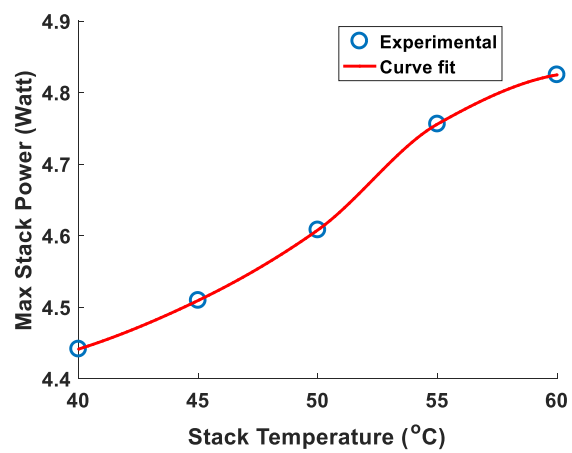

Figure 6: Effect of increasing stack temperature to the maximum achievable power from the PEM FC Stack at hydrogen pressure of 2.5 bar.

\subsection{Surface plot for fuel cell performance}

Figure 13 shows the general surface plot for the performance of the fuel cell at a specific temperature of $40^{\circ} \mathrm{C}$ but varying hydrogen and oxygen pressure. Figure 7 (a) shows that the maximum stack voltage can be obtained at high oxygen pressure and high hydrogen pressure but it is possible to still be in the red region of the graph with low hydrogen pressure and high oxygen pressure. Figure 7(b) also shows the maximum current that can be generated from the fuel cell while figure 7(c) shows the maximum stack power from the fuel cell. The efficiency of the cell is shown in figure 7(d)

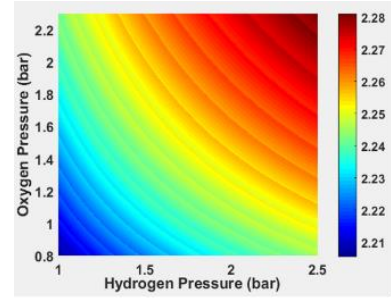

(a)

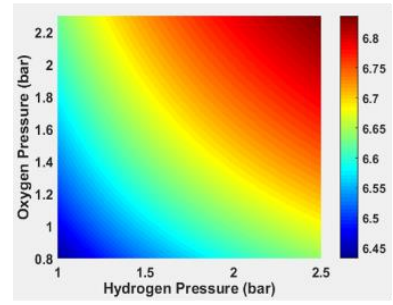

(c)

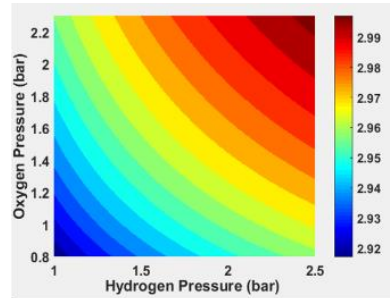

(b)

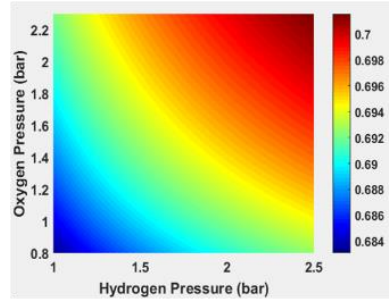

(d)

Figure 13: (a) Stack voltage (V) (b) Stack current (A) (c) Maximum Stack Power (W)

(d) Fuel Cell efficiency. The graphs have be generated at a temperature of $40^{\circ} \mathrm{C}$. 
$10^{\mathrm{TH}}$ INTERNATIONAL CONFERENCE ON SUSTAINABLE ENERGY AND ENVIRONMENTAL Protection (June $27^{\mathrm{TH}}-30^{\mathrm{TH}}, 2017$, Bled, Slovenia), ENERGy Storage

T.Wilberforce, F. N. Khatib, O. Emmanuel, O. Ijeaodola, A. Abdulrahman, A. Al Makky, A. Baroutaji \& A.G. Olabi: Experimental Study of Operational Parameters on the Performance of PEMFCS in Dead end Mode

\section{Conclusion}

The work was able to expose some parameters affecting the overall performance of fuel cell and the impact of these losses on the fuel cell performance. It was noticed that the activation loss in fuel cell is normally reduced with increased temperature due to an increase in exchange current density hence the overall performance of fuel cells increased once the operating temperature of the cell increased. Another reason was the fact that at high temperature the rate of reactions increases which tend to increase gas diffusivity in the membrane therefore making the fuel cell perform efficiently. Though increasing the temperature of the cell will increase the fuel cell performance, a critical temperature is established after a period of time where the performance of the cell begins to drop. This is due to an increase in membrane resistance as rate of evaporation of water in the membrane also increase. A solution is to keep the membrane well humidified by raising the temperature of the humidification chamber. This will in effect restore the membrane moisture thereby maintaining the fuel cell performance and even preventing the possibility of the membrane drying up at higher temperatures.

\section{References}

1. Tabbi Wilberforce, A. Alaswad, A. Palumbo, A. G. Olabi. Advances in stationary and portable fuel cell applications. International Journal of Hydrogen Energy 41(37) March 2016.

2. Tabbi Wilberforce, Ahmed Al Makky, A. Baroutaji, Rubal Sambi, A.G. Olabi. Computational Fluid Dynamic Simulation and modelling (CFX) of Flow Plate in PEM fuel cell using Aluminum Open Pore Cellular Foam Material. Power and Energy Conference (TPEC), IEEE, Texas. 2017.

3. Tabbi Wilberforce, Abed Alaswad, A.G. Olabi. Improving flow plate design in fuel cell. Poster presentation, RSC Scotand and North of England Regional Electrochemistry Symposium, April, 2016.

4. Tabbi Wilberforce, A. Alaswad, J. Mooney,A.G.Olabi.Hydrogen Production for Solar Energy Storage. A Proposed Design Investigation.Proceedings of the $8^{\text {th }}$ International Conference on sustainable Energy and Environmental Protection. ISBN: 978-1-903978$52-8$

5. Tabbi Wilberforce, Ahmed Al Makky, A. Baroutaji, Rubal Sambi, A.G. Olabi Optimization of bipolar plate through computational fluid dynamics simulation and modelling using nickle open pore cellular foam material. International conference on reneable energies and power quality (ICREPQ'17), ISSN 2171-038X, No 15 April 2017

6. Olabi AG. The 3rd international conference on sustainable energy and environmental protection SEEP 2009 the guest editor's introduction. Energy 2010;35:4508-9

7. Baroutaji, A., Carton, G. J., Olabi, A. G. Design and development of Proton Exchange Membrane Fuel Cell Using Open Pore Cellular Foam as Flow Plate Material. Journal of Energy Challenges and Mechanics. Volume 1 (2014) issue 2, article.

8. Alaswad A, Palumbo A, Dassisti M, Olabi AG. PEM fuel cell cost analysis during the period. In: Accepted in reference module in materials science and materials engineering (MATS). All rights reserved: 2016 Elsevier Inc; 1998-2014. 
$10^{\text {Th }}$ International Conference on Sustainable Energy and Environmental Protection (June 27 $7^{\mathrm{TH}}-30^{\mathrm{TH}}, 2017$, Bled, Slovenia), Hydrogen and Fuel Cells

T.Wilberforce, F. N. Khatib, O. Emmanuel, O. Ijeaodola, A. Abdulrahman, A. Al Makky, A. Baroutaji \& A.G. Olabi: Experimental Study of Operational Parameters on the Performance of PEMFCS in Dead end Mode

9. Rodriguez, C., Alaswad, A., Benyounis, K.Y., Olabi, A.G., 2017. Pretreatment techniques used in biogas production from grass. Renew. Sustain. Energy Rev. 68,1193-1204.

10. Rodriguez, C., Alaswad, A., Mooney, J., Prescott, T., Olabi, A.G., 2015. Pre-treatment techniques used for anaerobic digestion of algae. Fuel Process. Technol. 138, 765-779.

11. Carton, J. G., Olabi, A. G. Wind/hydrogen hybrid systems: opportunity for Ireland's wind resources to provide consistent sustainable energy supply. Energy 2010:35(12): 4536 - 44.

12. Baroutaji, A., Carton, G. J., Olabi, A. G. Design and development of Proton Exchange Membrane Fuel Cell Using Open Pore Cellular Foam as Flow Plate Material. Journal of Energy Challenges and Mechanics. Volume 1 (2014) issue 2, article.

13. Barrer RM, Barrie JA, Slater J. Sorption and diffusion in ethyl cellulose Part III. Comparison between ethyl cellose and Rubber. J Polym Sci 1958;27:177-97.

14. Park GS. Transport principles - solution, diffusion and permeation in polymer membranes, in: Bungay PM (Ed.), Synthetic membranes, science engineering and applications. Dordrecht: D. Reidel Publishing Company; 1986, p. 57-107.

15. Takata H, Nishikawa M, Arimura Y, Egawa T, Fukada S, Yoshitake M. Study on water uptake of proton exchange membrane by using tritiated water sorption method. Int $\mathbf{J}$ Hydrogen Energy 2005;30:1017-25.

16. M. P. Page, V. P - HerranzEffect of the operationandhumidifcation Temperatures on the performance of a PEM fuel cell stack on Dead - End Mode.

17. Anderson RB. Modification of the Brunauer Emmett and Teller equation. J Am Chem Soc 1946;68:686-91.

18. Colleen, S. S., Designing \& Building of fuel cell, $1^{\text {st }}$ ed. ISBN 0-07-148977-0, McGraw Hil, 2007.

19. Frano Barbir, PEM Fuel Cells: Theory and Prantice, Istanbul, Turkey, 2005.

Li, X. Principles of Fuel cells, Taylor and Francis, New York, 2006. 
$10^{\mathrm{TH}}$ InTERnational CONFERENCE ON Sustainable ENERgy AND

ENVIRONMENTAL Protection (June $27^{\mathrm{TH}}-30^{\mathrm{TH}}$, 2017, Bled,

Slovenia), Hydrogen AND Fuel Cells

J. Krope, A.Ghani Olabi, D. Goričanec \& S. Božičnik

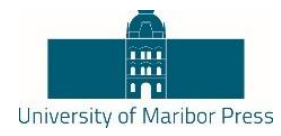

\title{
Characterisation of Proton Exchange Membrane (PEMFC) Fuel Cell Through Design of Experiment (DOE)
}

\author{
TABBi Wilberforce, FAWWAd NisAR KhatiB, AHMEd Al MaKKy, AHMAD \\ BAROUTAJI \& ABDUL GHANI OLABI
}

\begin{abstract}
This investigation reports the analysis of the performance of a PEM fuel cell through design of experiments (DOE). The various operational conditions like flow rates and pressure were optimized to determine the best condition that will generate optimum current and voltage to make the fuel cell efficient. This in effect will reduce the operational cost of running a fuel cell, as less input conditions were explored to generate more voltage and current from the 5-cell stack fuel cell. The experiments were conducted at temperatures ranging between $50 \mathrm{oC}$ and $60 \mathrm{oC}$. The work concluded that maintaining high pressures of the reactive gases but reducing the flow rate of the hydrogen whilst increasing the oxygen flow rate, provided maximum current and voltage from the fuel cell. Increasing the operating work conditions around the cell will cause the output response (voltage and current) to increase but will surely affect the operational cost of the fuel cell as more hydrogen and oxygen will be needed to sustain such demand. The work finally concluded that working parameters around the cathode significantly determined the performance of the fuel cell as any changes around the cathode either increased or decreased the final output of the cell.
\end{abstract}

Keywords: • Design of Experiments (DOE) • Flow rate • Pressure • Hydrogen • PEM fuel cell •

CORRESPONDENCE ADDRESS: Tabbi Wilberforce, University of the West of Scotland, Institute of Engineering and Energy Technologies, High St, Paisley PA1 2BE, United Kingdom, e-mail: B00281710@studentmail.uws.ac.uk. Fawwad Nisar Khatib, University of the West of Scotland, Institute of Engineering and Energy Technologies, High St, Paisley PA1 2BE, United Kingdom, email: Fawwad.Nisar@uws.ac.uk. Ahmed Al Makky PhD, University of the West of Scotland, Institute of Engineering and Energy Technologies, High St, Paisley PA1 2BE, United Kingdom, email: Ahmed.AlMakky@uws.ac.uk. Ahmad Baroutaji PhD, Cork Institute of Technology, Department of Process, Energy and Transport Engineering, Rossa Ave, Bishopstown, Cork, Ireland, email: ahmad.baroutaji2@mail.dcu.ie. Abdul Ghani Olabi, Professor, University of the West of Scotland, UK, Institute of Engineering and Energy Technologies, High St, Paisley PA1 2BE, United Kingdom, email: Abdul.Olabi@uws.ac.uk.

https://doi.org/10.18690/978-961-286-054-7.4

ISBN 978-961-286-054-7

(C) 2017 University of Maribor Press

Available at: http://press.um.si. 
$10^{\mathrm{TH}}$ InTERnAtional CONFERENCE ON Sustainable ENERGy AND ENVIRONMENTAL Protection (June 27 $7^{\mathrm{TH}}-30^{\mathrm{TH}}, 2017$, Bled, Slovenia), Hydrogen ANd Fuel Cells T. Wilberforce, F. N. Khatib, A. Al Makky, A. Baroutaji \& A.G. Olabi: Characterisation of Proton Exchange Membrane (PEMFC) Fuel Cell Through Design of Experiment (DOE)

\section{$1 \quad$ Introduction}

Recent interest in the development of different energy generation mediums such as fuel cells [1], have been seen due to the harsh environmental impact on the use of fossil fuel in the last decade. Some of the negative impacts on the reliance of fossil fuel are air pollution, extensive exploration of the worlds resources and political implications on countries that sometimes are naturally blessed with such resources [2]. It has therefore become very imperative that an alternative power source is needed that is energy efficient, has low pollutant emission and its supply of fuel is unlimited [3]. It is therefore possible to consider fuel cells as one of the alternative mediums to commercially supply power to meet the energy demand which is also environmentally friendly.

Some advantages of fuel cell systems are: they have high operating efficiency, they are capable of having several options in supplying the fuel to the stack. The fuel can be obtained from different sources as well, they also produce no or less pollutant harmful to living things, require low maintenance because they do not have moving parts capable of causing wear and tear or

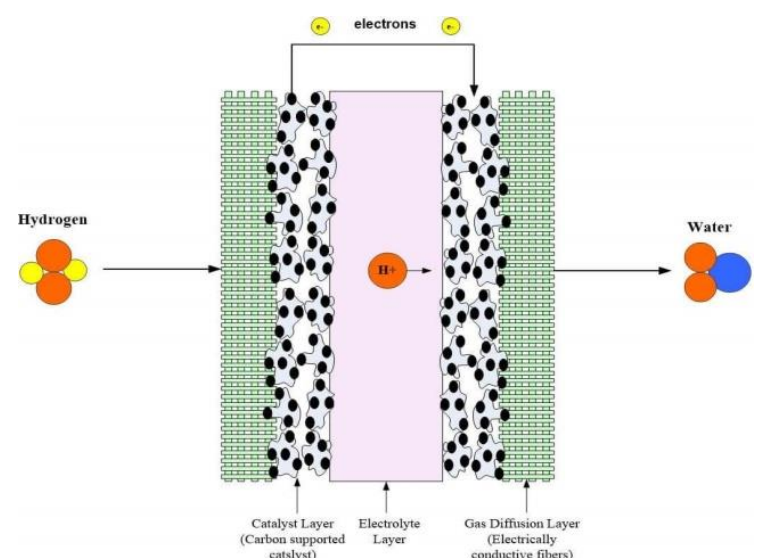

Figure 1: Various components in a hydrogen fuel cell

generating excessive heat and finally do not need being recharged as they provide power instantly when supplied with fuel. With all these advantages of fuel cell one may assume there are no demerits but they major challenge has to do with cost. This is because materials needed in building a fuel cell must come with some specifications especially on the catalytic layer where platinum is needed. Today fuel cells are being used to power portable devices like toys, large stationary device and even in the automobile industry [48].

There are several types of fuel cell and each type is often named according to the electrolyte they are made off but the proton exchange membrane fuel cell is currently the 
most dominant among all the types. They are considered to have a fast start-up and shut down, high power density, low operating temperatures and the design of the stack are also simple compared to the others. For PEM fuel cell to compete with other fuel cells on the market, it's important that the cost and weight is reduced significantly. One of the pragmatic ways of improving the performance of any fuel cell is by varying the operational parameters of the fuel cell [9]. The operating condition of fuel cell play a key role in the final output of the stack. It is therefore imperative that the best conditions that gives the maximum performance of the fuel cell is well known. For instance, the conditions leading to the maximum power and current density must all be established for any fuel cell [10]. The knowledge of the complete operational map will allow to efficiently use the device and even reduce the possibility of it being damaged. Some works have been carried out on fuel cell operating conditions to achieve the best performance, however these works do not consider the possibility of integrating surface responses and design of experiment analysis to predict the optimal conditions for any fuel cell.

\section{$2 \quad$ Testing of Fuel Cell}

A fuel cell with a serpentine flow plate design was purchased from Fuel cell store in the United States(US) with an active area of $11.46 \mathrm{~cm}^{2}$. One of the manufacturers specification was to have the membrane humidified to prevent the possibility of it drying up. The PEM fuel cell was dismantled as shown in Figure 2, to examine how the various components interacted with each other in the cell, and to get an idea on the impact of the operating conditions were likely to have on each layer in the stack.

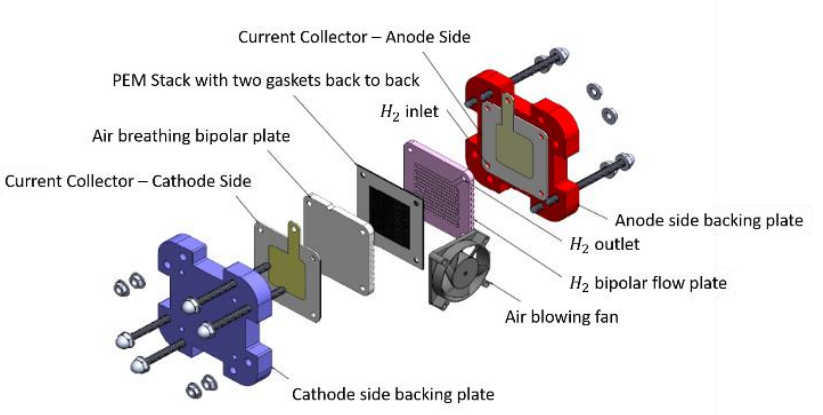

Figure 2: 3D view of the Fuel cell purchase from fuel cell store, US.

\subsection{Design of experiments}

Design of experiments (DOE) is a mathematical method for planning and performing scientific studies that change experimental variables together to determine their effect on a given response. It also makes controlled changes to input variables to gain maximum amount of information on cause and effect relationships with minimum sample size. DOE 
$10^{\mathrm{TH}}$ InTERnATIONAL CONFERENCE ON Sustainable ENERgy AND ENVIRONMENTAL Protection (June $27^{\mathrm{TH}}-30^{\mathrm{TH}}, 2017$, Bled, Slovenia), Hydrogen and Fuel Cells T. Wilberforce, F. N. Khatib, A. Al Makky, A. Baroutaji \& A.G. Olabi: Characterisation of Proton Exchange Membrane (PEMFC) Fuel Cell Through Design of Experiment (DOE)

is efficient is essence, that changing one variable at a time can predict the impact on any given response. It gives out information based on the effect of different factors has on a response variable. In some cases, DOE, may be able to determine optimal settings for those factors. Figure 3 shows the basic steps in any DOE analysis.

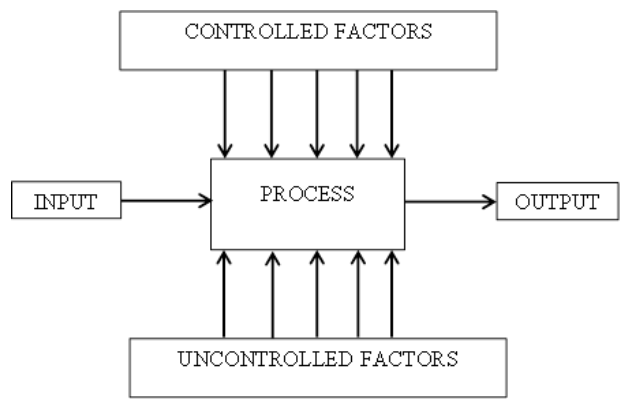

Figure 3: Design of Experiment approach

\subsection{Box - Behnken design}

The Box - Behnken design is a response surface design which is also described as an independent quadratic design. It implies that this response surface design does not have any embedded factorial or fractional factorial design. The treatment combination for this design is centred on the midpoints of edges of the process space and at the centre. They are rotatable (or near rotatable) and require 3 levels of each factor as shown in Table 2. They have limitations for orthogonal blocking compared to the central composite [11].

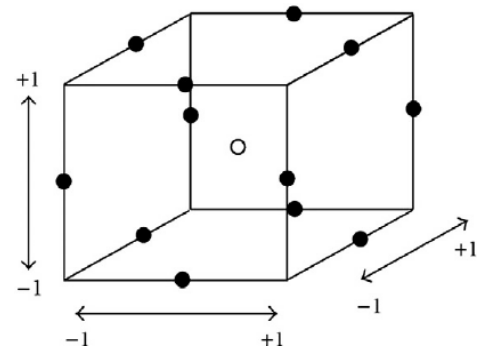

Figure 4: Geometry of Box - Behnken design for optimization of three parameter process.

Blocking is a technique used to increase the precision of an experiment by breaking the experiment into homogenous segments (blocks) to control a potential block to block variability. The effects on the experimental result because of the blocking factor are minimized. The main levels considered were coded as $-1,0$, and +1 as shown in Figure 4. 
$10^{\mathrm{TH}}$ INTERNATIONAL CONFERENCE ON SUSTAINABLE ENERGY AND ENVIRONMENTAL Protection (June $27^{\mathrm{TH}}-30^{\mathrm{TH}}, 2017$, Bled, Slovenia), ENERGy StORAGE

T. Wilberforce, F. N. Khatib, A. Al Makky, A. Baroutaji \& A.G. Olabi: Characterisation of Proton Exchange Membrane (PEMFC) Fuel Cell Through Design of Experiment

(DOE)

They are formed by combining two - level factorial designs with incomplete block design [12]. This approach generates designs with desirable statistical properties but only a fraction of the experiments is required fora three level factorial. The quadratic model is often the most preferred because there are three levels. The number of centre point selected was 1 , in order to reduce the amount of experiments and also because the centre point was not considered to be an important position. There are other types of statistical programs that can be used to set up and analyse a DOE. Stat-Ease or Mini tab are two common programs that can be used in DOE analysis. This analysis was performed using DOE, Stat-Ease because it dedicates itself for providing the best program for design and analysis of experiments and proved to be more than satisfactory for this type of study [13].

\subsection{Experimental parameters}

The experiment was performed considering the effect of three parameters on the performance of the fuel cell. The various conditions were also optimized to determine the best operating conditions to achieve the maximum voltage and current. Several graphs were generated through DOE in response to these operating parameters. The air pressure was initially set to be below the hydrogen pressure but from the manufacturers' specification, the oxygen had to be supplied in large quantities as shown in Table 2.

Table 2: Fuel cell experimental parameters.

\begin{tabular}{|c|c|c|c|}
\hline DOE level & -1 & 0 & +1 \\
\hline Parameter level & Low & Medium & High \\
\hline $\begin{array}{c}\text { Hydrogen } \\
\text { pressure }\end{array}$ & 1 bar & $1.75 \mathrm{bar}$ & $2.5 \mathrm{bar}$ \\
\hline $\begin{array}{c}\text { Air/oxygen } \\
\text { pressure }\end{array}$ & $0.8 \mathrm{bar}$ & $1.55 \mathrm{bar}$ & $2.3 \mathrm{bar}$ \\
\hline $\begin{array}{c}\text { Hydrogen } \\
\text { volumetric flow } \\
\text { rate }\end{array}$ & $15 \mathrm{ml} / \mathrm{min}$ & $\begin{array}{c}82.5 \\
\mathrm{ml} / \mathrm{min}\end{array}$ & $\begin{array}{c}150 \\
\mathrm{ml} / \mathrm{min}\end{array}$ \\
\hline $\begin{array}{c}\text { Oxygen } \\
\text { volumetric flow } \\
\text { rate }\end{array}$ & $15 \mathrm{ml} / \mathrm{min}$ & $\begin{array}{c}82.5 \\
\mathrm{ml} / \mathrm{min}\end{array}$ & $\begin{array}{c}150 \\
\mathrm{ml} / \mathrm{min}\end{array}$ \\
\hline
\end{tabular}

\section{$2.4 \quad$ Experimental set up}

The hydrogen gas was produced using a hydrogen generator from Peak Instrument, UK where the reacting oxygen was obtained by directing air through the air vents of the fuel cell with the aid of a fan. The pressure of the hydrogen fuel was varied between $1 \mathrm{bar}$ and 2.5 bar. The fuel (hydrogen) was then directed through a flow meter to determine the flow rate of the gas before entering the fuel cell. Once the flow rate of the gas was determined, the hydrogen was then passed through a humidified chamber before finally entering the 
$10^{\mathrm{TH}}$ InTERnAtional CONFERENCE ON Sustainable ENERgy AND ENVIRONMENTAL Protection (June $27^{\mathrm{TH}}-30^{\mathrm{TH}}, 2017$, Bled, Slovenia), Hydrogen and Fuel Cells T. Wilberforce, F. N. Khatib, A. Al Makky, A. Baroutaji \& A.G. Olabi: Characterisation of Proton Exchange Membrane (PEMFC) Fuel Cell Through Design of Experiment (DOE)

anode region of the fuel cell, as in [14]. The working environment for the experiment had a relative humidity of 0.74 and the air flow rate was also determined from the data sheet of the fan used in the experiment.

A potentiostat from Gamry Instrument was used to generate the polarization curve at each working condition. The open circuit voltage and current was also determined using a multi meter. A thermocouple was attached to the fuel cell to determine the cell operating temperature at varying operating condition. The fuel cell was operated at temperatures in the range $50^{\circ} \mathrm{C}-60^{\circ} \mathrm{C}$.

\section{$3 \quad$ Analysisof Data}

The design of experiment was first used to determine the accuracy and to predict possible errors prior to each response being analysed and graphed statistically. The software automatically lists each execution in randomized order which protect against any lurking factors such as time, temperature, humidity etc. A number of factors can be used to correct the errors in the experiment [15]. In DOE, one of the approaches is to check the significance of the model in the ANOVA. ANOVA is analysis of variance, a statistical method in which the variation in a set of observations is divided into distinct components. For the experimental model o used for this investigation, the F-value was 11.04 which indicated that the model was significant. There was only a $0.01 \%$ chance that an F-value this large could occur due to noise. Values of "Prob > F" less than 0.0500 indicate model terms are significant. From the model intercept, $\mathrm{D}, \mathrm{AB}, \mathrm{B}^{\wedge} 2, \mathrm{C}^{\wedge} 2, \mathrm{D}^{\wedge} 2$ were significant model terms. Again an insignificant model can be made significant by reducing the model. Another important parameter to carefully consider in the ANOVA is the "Pred RSquared". The "Pred R-Squared" value for this experiment was 0.5408 and this was also not so close to the "Adj R-Squared" of 0.7416. The difference was more than 0.2. The model could be reduced further or the response could be transformed further. "Adeq Precision" in ANOVA measures the signal to noise ratio. The normally accepted ratio is 4 but the ratio for the model for the experiment was 12.015 making it very suitable for the DOE analysis. According to Montgomery, 2001 transformation sometimes skewed the results so it's often advanced that is used as the last resort in getting the values either significant or the difference between "0Adj R-Squared" and "Adeq Precision" less than 0.2. The normal plot in diagnostics as shown in Figure 5 is used to determine whether the results are normally distributed [16-20]. Under normal circumstances, the normal plot of residual should be a straight line showing no abnormalities. From the normality plot, there is linearity between the experimental set points. 


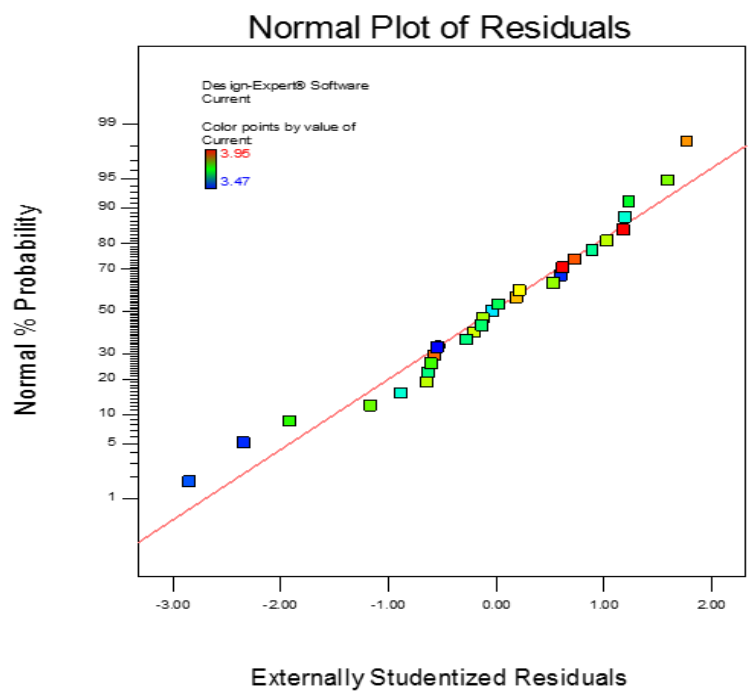

Figure 5: Normality plot for the experimental model.

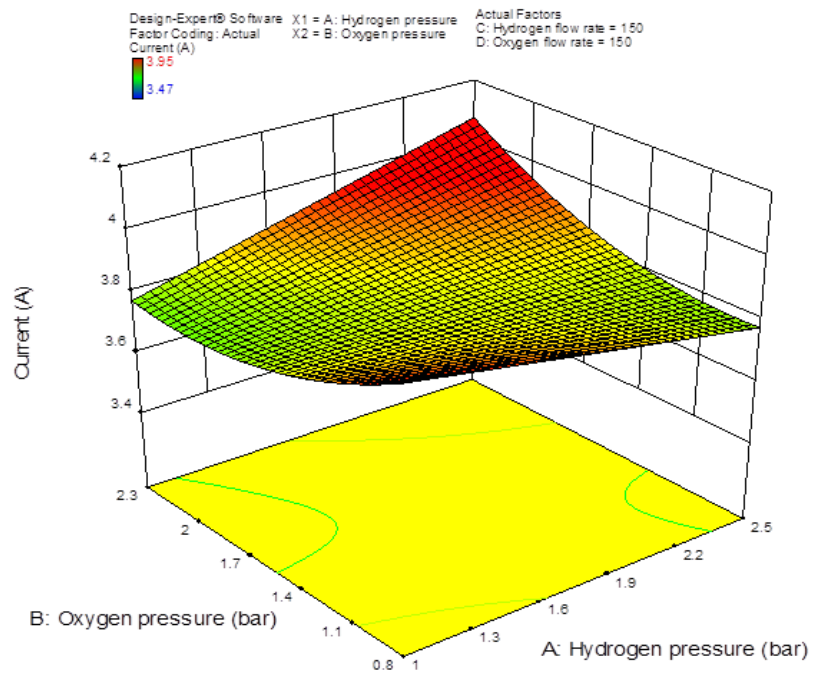

Figure 6: Plot to determine the operation condition to generate the maximum current from the fuel cell at maximum pressure. 
$10^{\mathrm{TH}}$ InTERnATIONAL CONFERENCE ON Sustainable ENERgy AND ENVIRONMENTAL Protection (June 27 $7^{\mathrm{TH}}-30^{\mathrm{TH}}, 2017$, Bled, Slovenia), Hydrogen ANd Fuel Cells T. Wilberforce, F. N. Khatib, A. Al Makky, A. Baroutaji \& A.G. Olabi: Characterisation of Proton Exchange Membrane (PEMFC) Fuel Cell Through Design of Experiment (DOE)

\subsection{Results and Discussion}

\subsection{Current}

From the analysis made in the design of experiment, the highest current of $4.15 \mathrm{~A}$ was achieved by increasing the oxygen flow rate $(150 \mathrm{ml} / \mathrm{min})$ and increasing the hydrogen flow rate $(150 \mathrm{ml} / \mathrm{min})$ as shown in Figure 6.

A low hydrogen flow rate of $15 \mathrm{ml} / \mathrm{min}$ but high oxygen flow rate of $150 \mathrm{ml} / \mathrm{min}$ at maximum pressure can equally generate high amount of current from the fuel cell as shown in Figure 7

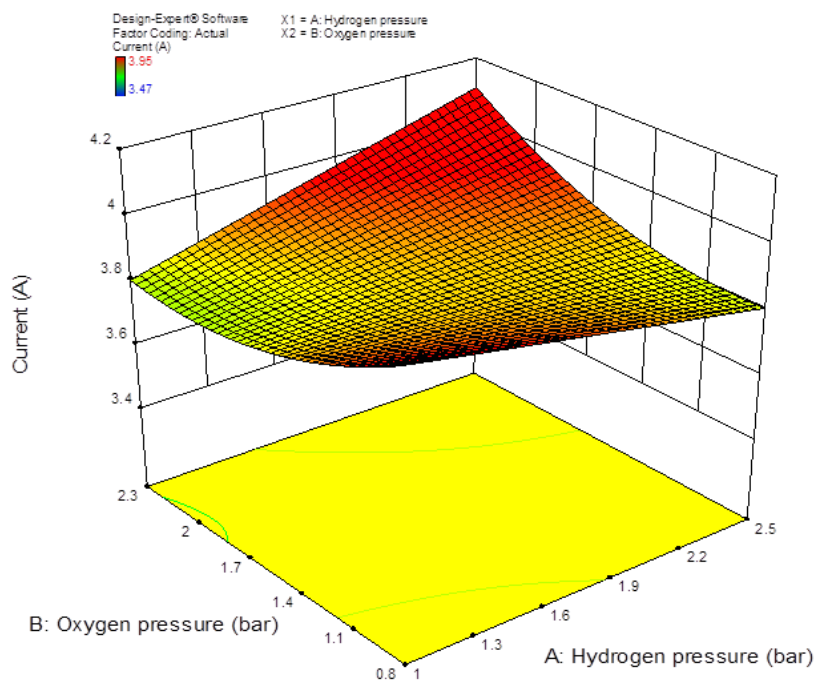

Figure 7: Plot of low hydrogen flow rate $(15 \mathrm{ml} / \mathrm{min})$ but high oxygen flow rate $(150 \mathrm{ml} / \mathrm{min})$ still yield maximum current from the fuel cell.

Figure 8 shows that reducing the pressure of the gas to the least minimum value but increasing the flow rate of the reactant will still generate high amount of current. 
T. Wilberforce, F. N. Khatib, A. Al Makky, A. Baroutaji \& A.G. Olabi: Characterisation of Proton Exchange Membrane (PEMFC) Fuel Cell Through Design of Experiment

(DOE)

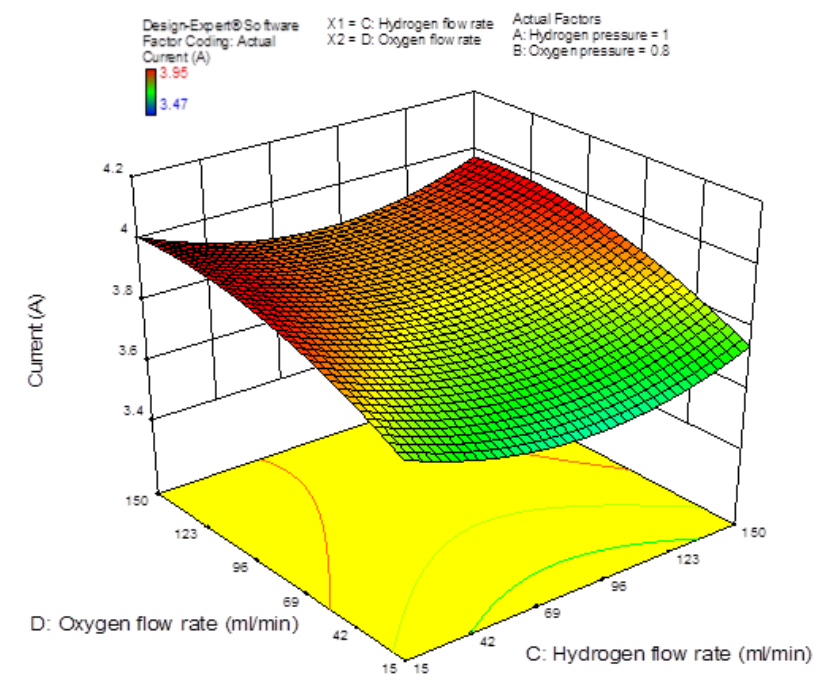

Figure 8: Plot of low gas pressure but high flow rates can still generate maximum current from the fuel cell.

\subsection{Voltage}

From Figure 9, increasing all parameters both voltage and current will affect the general performance of the fuel cell by increasing the open circuit voltage. From Figure 10 increasing everything will contribute to the fuel cell performing better but this may not be the most efficient approach as it will eventually increase the general cost of running the fuel cell. Hence a much easier and cheaper approach is to increase the hydrogen flow rate but reduce the oxygen flow rate. Reducing the gas pressure as shown in figure 11 will reduce the general performance of the fuel cell from its initial voltage of $4.7 \mathrm{~V}$ to $4.4 \mathrm{~V}$, an indication that a fairly high pressure should be maintained whilst varying the flow rate if the fuel cell performance is to be kept constant. 
$10^{\mathrm{TH}}$ INTERNATIONAL CONFERENCE ON Sustainable ENERGY AND ENVIRONMENTAL Protection (June $27^{\mathrm{TH}}-30^{\mathrm{TH}}, 2017$, Bled, Slovenia), Hydrogen and Fuel Cells T. Wilberforce, F. N. Khatib, A. Al Makky, A. Baroutaji \& A.G. Olabi: Characterisation of Proton Exchange Membrane (PEMFC) Fuel Cell Through Design of Experiment (DOE)

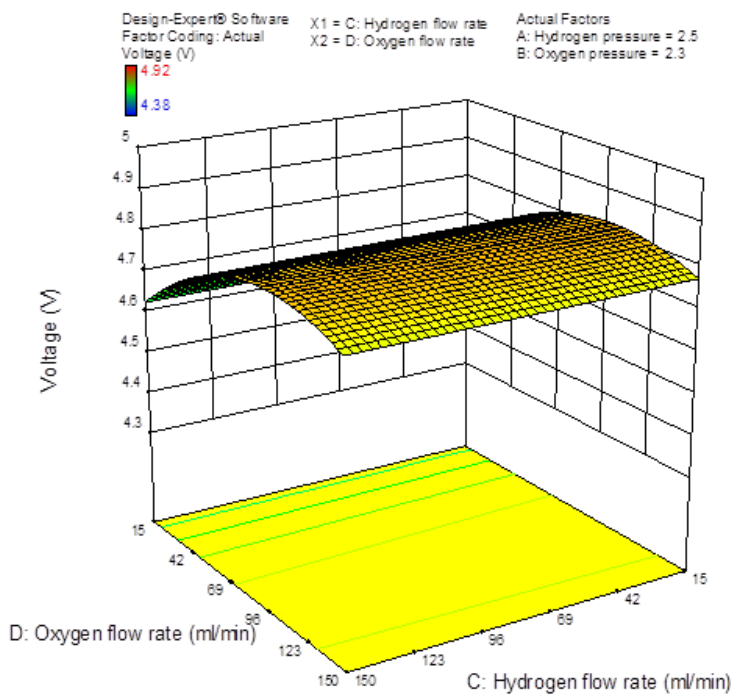

Figure 9: Increasing all parameters for the fuel cell.

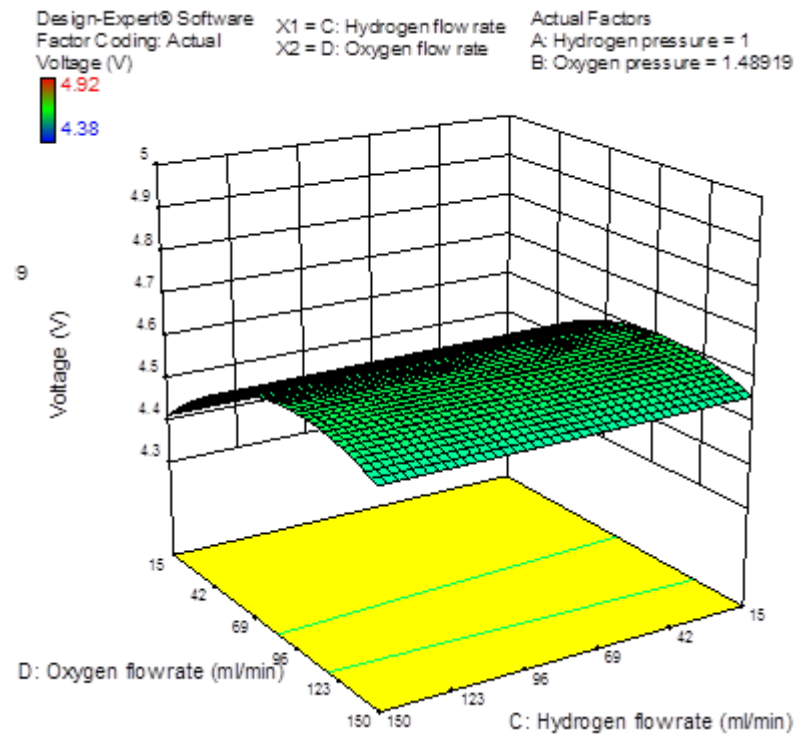

Figure 10: Operational performance of fuel cell at reduced pressures but high flow rates. 
T. Wilberforce, F. N. Khatib, A. Al Makky, A. Baroutaji \& A.G. Olabi: Characterisation of Proton Exchange Membrane (PEMFC) Fuel Cell Through Design of Experiment

(DOE)

\subsection{Optimization of parameters}

It is possible to optimize the various operational parameters to determine the best working condition to make the fuel cell efficient through DOE. By optimization, one can predict the optimum pressure and flow rate to achieve high efficiency at a reduced operational cost from the fuel cell. The optimization package in DOE can be done numerically as shown in Figure 11 or graphically in Figure 12 and 13.
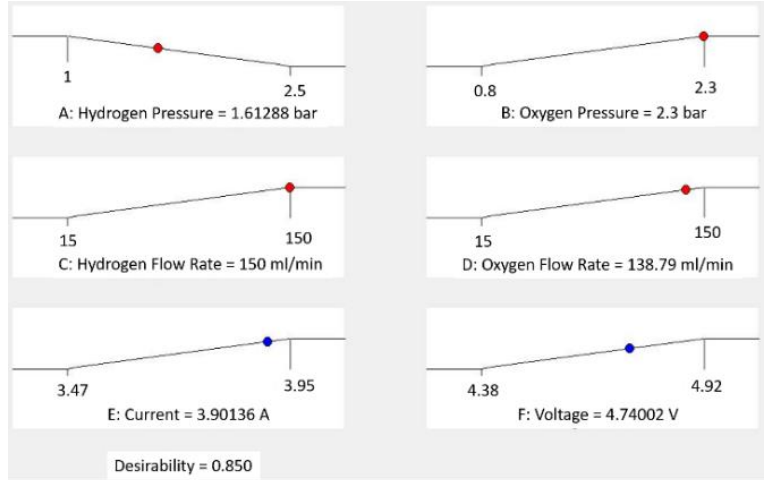

Figure 11: Optimization of operating parameters to determine the best conditions for maximum output from the fuel cell.

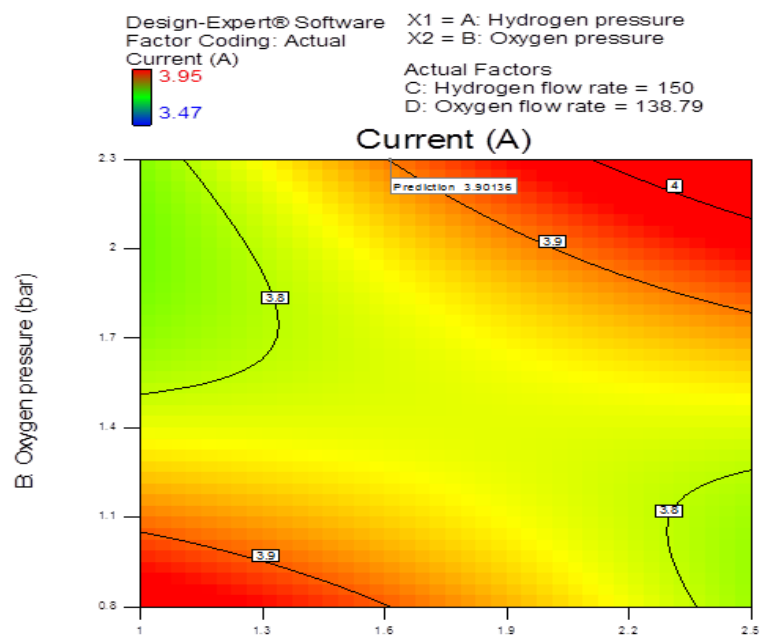

A: Hydrogen pressure (bar)

Figure 12: Graph of the best conditions to obtain the maximum current from the fuel cell. 
$10^{\mathrm{TH}}$ InTERnATIONAL CONFERENCE ON Sustainable ENERgy AND ENVIRONMENTAL Protection (June 27 $7^{\mathrm{TH}}-30^{\mathrm{TH}}, 2017$, Bled, SLovenia), Hydrogen ANd Fuel Cells

T. Wilberforce, F. N. Khatib, A. Al Makky, A. Baroutaji \& A.G. Olabi: Characterisation of Proton Exchange Membrane (PEMFC) Fuel Cell Through Design of Experiment (DOE)

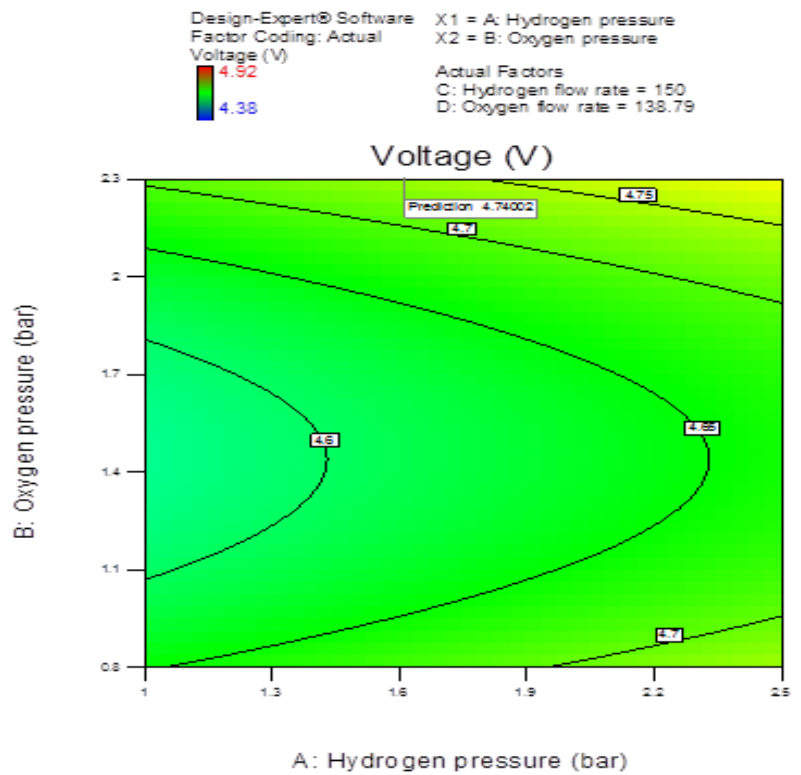

Figure 13: Graph of the best conditions to obtain the maximum voltage from the fuel from the fuel cell.

Various conditions can be set under the optimization package. For instance, the operational limit can be set and reduced to know the working conditions to obtain the optimal result. Once the criteria has been set for the conditions the software generates the best operating parameters to give the maximum results. From Figure 11, it is observed that increasing the oxygen pressure but keeping the flow rate high will generate a maximum current of $3.9 \mathrm{~A}$ and maximum voltage of $4.7 \mathrm{~V}$. The graphical representation is as shown in Figure 12 and 13. 


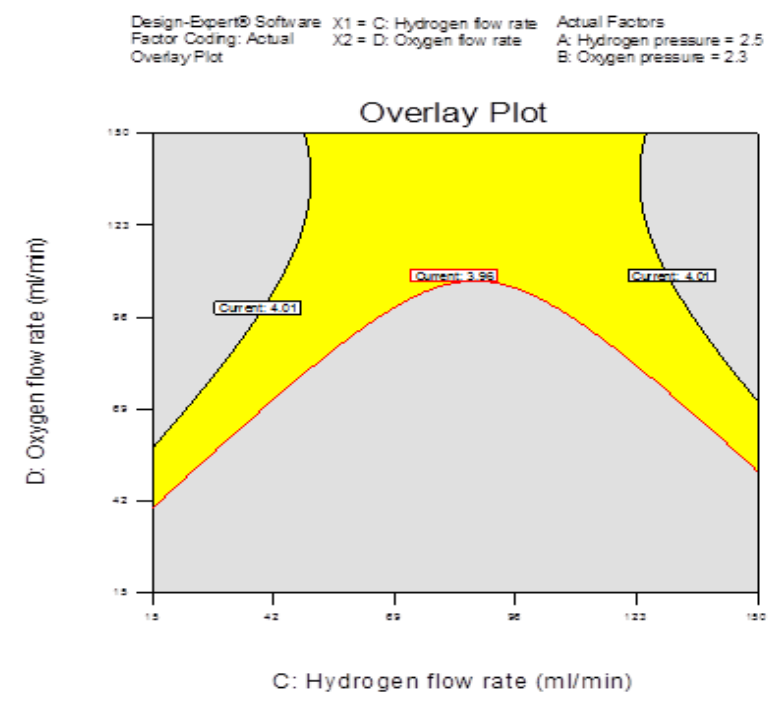

Figure 14: Graph of the best conditions to obtain the maximum current from the fuel cell.

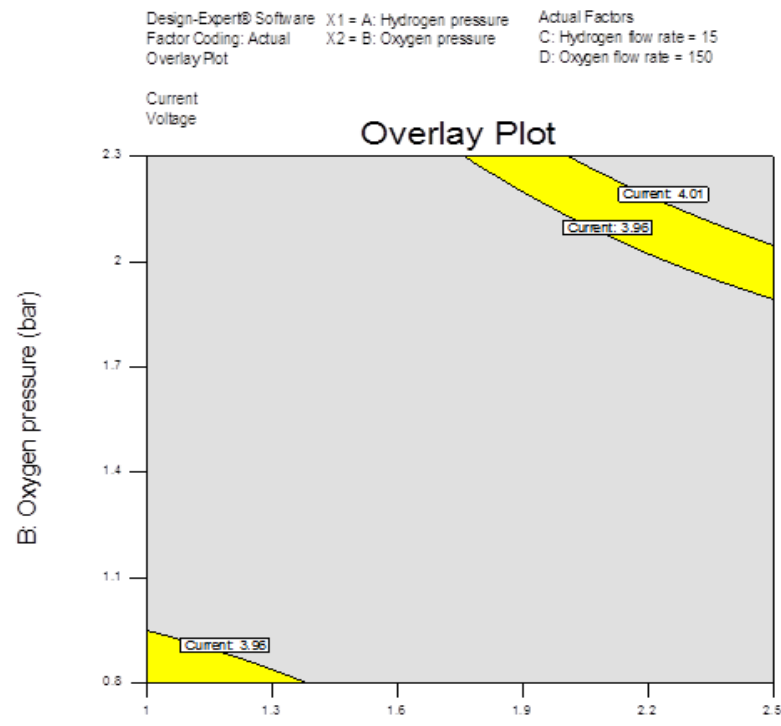

A: Hydrogen pressure (bar)

Figure 15: Performance of the fuel cell with respect to high oxygen flow rate but low hydrogen flow rate at high operational pressures. 
$10^{\mathrm{TH}}$ InTERnATIONAL CONFERENCE ON Sustainable EnERgy AND ENVIRONMENTAL Protection (June $27^{\mathrm{TH}}-30^{\mathrm{TH}}, 2017$, Bled, Slovenia), Hydrogen and Fuel Cells T. Wilberforce, F. N. Khatib, A. Al Makky, A. Baroutaji \& A.G. Olabi: Characterisation of Proton Exchange Membrane (PEMFC) Fuel Cell Through Design of Experiment (DOE)

Optimization was also done graphically to predict the best working range for the fuel cell to work efficient shown in Figure 14. This gave a fair idea to specifically know the best condition or area one should maintain the operating parameters to achieve the maximum current from the fuel cell. The yellow region from Figure 15 indicates the region where the fuel cell will be operating at its maximum potential.

It can be seen from Figure 15, that reducing the hydrogen flow rate but maintaining the oxygen flow rate at high maximum pressure will still eventually lead to the fuel cell generating good amount of current in the yellow region.

\section{$5 \quad$ Conclusion}

Several parameters are taken into consideration when optimizing the performance of a fuel cell. The general working conditions contribute significantly to the performance of the cell. In order to predict the best operational conditions for the fuel cell, DOE(s) were performed to record the inputs and determine the output. Predictions were made based on the best result for each DOE. It is possible for an error to be corrected and situations where the input data was not significant. They were checked by ensuring that they were correctly keyed into the software and the experiment performed satisfactorily. From the results, it was observed that increasing all parameters of the fuel cell eventually increased the performance of the fuel cell, with certain limitations. Applying this approach means more hydrogen and oxygen is needed which will eventually affect the operational cost of the fuel. Several parameters were varied but the best operational condition yielding the maximum current and voltage was found by reducing the fuel(hydrogen) flow rate but increasing the oxygen flow rate while maintaining constant pressure for both reactive gases. The parameters were also optimized using both numerical and graphical package in DOE. In a nut shell, the performance of the fuel cell is highly dependent on the conditions occurring at the cathode region whilst that at the anode, have least influence on the performance of the fuel cell except at very high conditions.

\section{References}

1. Tabbi Wilberforce, A. Alaswad, A. Palumbo, A. G. Olabi. Advances in stationary and portable fuel cell applications. International Journal of Hydrogen Energy 41(37) March 2016.

2. Tabbi Wilberforce, A. Alaswad, J. Mooney,A.G.Olabi.Hydrogen Production for Solar Energy Storage. A Proposed Design Investigation.Proceedings of the $8^{\text {th }}$ International Conference on sustainable Energy and Environmental Protection. ISBN: 978-1-903978$52-8$.

3. Tabbi Wilberforce, Ahmed Al Makky, A. Baroutaji, Rubal Sambi, A.G. Olabi. Computational Fluid Dynamic Simulation and modelling (CFX) of Flow Plate in PEM fuel cell using Aluminum Open Pore Cellular Foam Material. Power and Energy Conference (TPEC), IEEE, Texas. 2017. DOI: 10.1109/TPEC.2017.7868285. 
$10^{\mathrm{TH}}$ INTERNATIONAL CONFERENCE ON SUSTAINABLE ENERGY AND ENVIRONMENTAL Protection (June 27 $7^{\mathrm{TH}}-30^{\mathrm{TH}}, 2017$, Bled, Slovenia), ENERgy Storage

T. Wilberforce, F. N. Khatib, A. Al Makky, A. Baroutaji \& A.G. Olabi: Characterisation of Proton Exchange Membrane (PEMFC) Fuel Cell Through Design of Experiment

(DOE)

4. Tabbi Wilberforce, Abed Alaswad, A.G. Olabi. Improving flow plate design in fuel cell. Poster presentation, RSC Scotand and North of England Regional Electrochemistry Symposium, April, 2016.

5. Tabbi Wilberforce, Ahmed Al Makky, A. Baroutaji, Rubal Sambi, A.G. Olabi Optimization of bipolar plate through computational fluid dynamics simulation and modelling using nickle open pore cellular foam material. International conference on reneable energies and power quality (ICREPQ'17), ISSN 2171-038X, No 15 April 2017

6. Olabi AG. The 3rd international conference on sustainable energy and environmental protection SEEP 2009 the guest editor's introduction. Energy 2010;35:4508-9

7. Baroutaji, A., Carton, G. J., Olabi, A. G. Design and development of Proton Exchange Membrane Fuel Cell Using Open Pore Cellular Foam as Flow Plate Material. Journal of Energy Challenges and Mechanics. Volume 1 (2014) issue 2, article.

8. Alaswad A, Palumbo A, Dassisti M, Olabi AG. PEM fuel cell cost analysis during the period. In: Accepted in reference module in materials science and materials engineering (MATS). All rights reserved: 2016 Elsevier Inc; 1998-2014.

9. Carton, J. G., Olabi, A. G. Wind/hydrogen hybrid systems: opportunity for Ireland's wind resources to provide consistent sustainable energy supply. Energy 2010:35(12): 4536 - 44.

10. Baroutaji, A., Carton, G. J., Olabi, A. G. Design and development of Proton Exchange Membrane Fuel Cell Using Open Pore Cellular Foam as Flow Plate Material. Journal of Energy Challenges and Mechanics. Volume 1 (2014) issue 2, article.

11. Barrer RM, Barrie JA, Slater J. Sorption and diffusion in ethyl cellulose Part III. Comparison between ethyl cellose and Rubber. J Polym Sci 1958;27:177-97.

12. Park GS. Transport principles - solution, diffusion and permeation in polymer membranes, in: Bungay PM (Ed.), Synthetic membranes, science engineering and applications. Dordrecht: D. Reidel Publishing Company; 1986, p. 57-107.

13. Takata H, Nishikawa M, Arimura Y, Egawa T, Fukada S, Yoshitake M. Study on water uptake of proton exchange membrane by using tritiated water sorption method. Int $\mathrm{J}$ Hydrogen Energy 2005;30:1017-25.

14. M. P. Page, V. P - HerranzEffect of the operationandhumidifcation Temperatures on the performance of a PEM fuel cell stack on Dead - End Mode.

15. Anderson RB. Modification of the Brunauer Emmett and Teller equation. J Am Chem Soc 1946;68:686-91.

16. Tsonos C, Apekis L, Pissis P. Water sorption and dielectric relaxation spectroscopy studies in hydrated Nafion_(-SO3K) membranes. J Mater Sci 2000;35:5957-65

17. Colleen, S. S., Designing \& Building of fuel cell, $1^{\text {st }}$ ed. ISBN 0-07-148977-0, McGraw Hil, 2007.

18. Springer et al. Polymer Electrolyte Fuel cell Model.

19. Subash, Singhall C. High Temperature Solid Oxide fuel cells fundamentals, Design and Applications. PanAmerican Advanced Studies Institute. Rio de Janeiro

20. Nishikawa M, Takeishi T, Enoeda M, Higashijima T, Munakata K, Kumabe I. Catalytic oxidation of tritium in wet gas. J Nucl Sci Technol 1985;22:922-33. 
$52 \quad 10^{\mathrm{TH}}$ International Conference on Sustainable EnERgy and ENVIRONMENTAL Protection (June 27 $7^{\mathrm{TH}}-30^{\mathrm{TH}}, 2017$, Bled, Slovenia), Hydrogen And Fuel Cells) 
$10^{\mathrm{TH}}$ InTERnational CONFEREnCE ON Sustainable ENERgy AND ENVIRONMENTAL Protection (June $27^{\mathrm{TH}}-30^{\mathrm{TH}}$, 2017, Bled, Slovenia), Hydrogen AND Fuel Cells

J. Krope, A.Ghani Olabi, D. Goričanec \& S. Božičnik

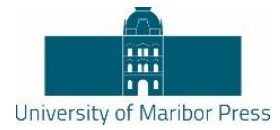

\title{
$\mathrm{Cu} / \mathrm{CGO}$ Cermet Based Electrodes for Symmetric and Reversible Solid Oxide Fuel Cells
}

\author{
Giovanni Carollo, Alberto Garbujo, Davide Ferri, Marta Maria NAtile \& \\ ANTONELLA GLISENTI
}

\begin{abstract}
Cu}$-based cermets suitable for electrodes in Symmetric and Reversible Solid Oxide Fuel Cells (SR-SOFCs) based on Cerium Gadolinum Oxide (CGO) electrolyte were developed and successfully tested in the intermediate temperature range. The $\mathrm{Cu} / \mathrm{CGO}$ cermets were prepared by a self-combustion based citrate procedure and the effects of synthesis conditions were studied. Characterization of the $\mathrm{Cu} / \mathrm{CGO}$ nanocomposites by XPS, XRD, SEM, EDX, TPR suggested that this procedure allows obtaining highly dispersed $\mathrm{CuO}$ on the cerium gadolinium oxide. Conversion higher than $80 \%$ was observed above $600^{\circ} \mathrm{C}$ in methane total oxidation. Synthesis parameters affected properties and catalytic performance.

The behaviour under redox conditions was studied by operando highenergy XRD under oscillating $\mathrm{H} 2 / \mathrm{O} 2$ feed. Reducing conditions convert $\mathrm{CuO}$ into $\mathrm{Cu}(0)$ passing through an intermediate $\mathrm{Cu} 2 \mathrm{O}$ phase while increasing the conductivity and the reactivity. This structural modification is completely reversible. The high stability, reversibility, catalytic activity, and electrochemical performance (EIS) make these electrodes promising for SR-SOFCs.
\end{abstract}

Keywords: • $\mathrm{SOFC} \bullet \mathrm{Cu}$-cermet $\bullet$ anode $\bullet \mathrm{CGO} \bullet$ methane $\bullet$

CORRESPONDENCE ADDRESS: Giovanni Carollo, Master Student, University of Padova, Department of Chemical Sciences, Via Francesco Marzolo 1, 35131 Padova, Italy, email: giovanni.carollo.1@studenti.unipd.it. Alberto Garbujo, Ph.D. Student, University of Padova, Department of Chemical Sciences, Via Francesco Marzolo 1, 35131 Padova, email: alberto.garbujo@phd.unipd.it. Davide Ferri, Ph.D., Senior Scientist, Paul Scherrer Institut, Villigen PSI, 5232, Switzerland, email: davide.ferri@ psi.ch. Marta Maria Natile, Ph.D., Research Scientist, CNR-ICMATE, Department of Chemical Sciences, Via Francesco Marzolo 1, 35131 Padova, Italy, email: martamaria.natile@unipd.it. Antonella Glisenti, Ph.D., Associate Professor, University of Padova, Department of Chemical Sciences, CNR-ICMATE, Via Francesco Marzolo 1, 35131 Padova, Italy, email: antonella.glisenti@unipd.it.

https://doi.org/10.18690/978-961-286-054-7.5

ISBN 978-961-286-054-7

(C) 2017 University of Maribor Press

Available at: http://press.um.si. 
$10^{\mathrm{TH}}$ InTERnATIONAL CONFERENCE ON Sustainable ENERgy AND ENVIRONMENTAL Protection (June $27^{\mathrm{TH}}-30^{\mathrm{TH}}, 2017$, Bled, Slovenia), Hydrogen and Fuel Cells G. Carollo, A. Garbujo, D. Ferri, M. M. Natile \& A. Glisenti: Cu/CGO Cermet Based Electrodes for Symmetric and Reversible Solid Oxide Fuel Cells

Ni-YSZ cermets are the most traditionally diffused anodes for Solid Oxide Fuel Cells (SOFCs) but their use in direct methane fuel cells is complicated by their capability to catalyse the formation of carbon filaments that cause the efficiency loss of the device [1]. A suitable anode for the direct oxidation of methane needs good electronic conductivity and electrocatalytic activity decoupled from the tendency to form carbon. Copper based ceria cermets demonstrated to be advantageous in replacing Ni-cermets for direct hydrocarbons SOFCs [2-6]. In these cermets the electrical conductivity is warranted by copper, whereas ceria is responsible for the catalytic activity in oxidation reactions. Moreover, $\mathrm{Ce}_{0.9} \mathrm{Gd}_{0.1} \mathrm{O}_{1.95}$ (CGO10) is an ionic conductor capable to operate at intermediate temperature $\left(600-800^{\circ} \mathrm{C}\right)$, thus opening interesting opportunities for a wider application of these devices. In the present contribution, we developed and optimized a new procedure for the $\mathrm{Cu}-\mathrm{CGO} 10$ cermet synthesis using the citrate route in order to obtain highly dispersed $\mathrm{CuO}$ nanoparticles in CGO10.

In addition to the traditional SOFC geometry a CGO-based symmetric configuration can be considered, through an appropriate optimization of the electrodes. This approach could greatly simplify the production of fuel cells because the electrodes' assembling can be carried out in one thermal step decreasing the fabrication costs. Even more important, compatibility troubles can be minimized and the problems related to poisoning (sulphur, carbon deposition) simply addressed by reversing the gas flow. To reach this objective, beside electronic conductivity and electrocatalytic activity, stability/reversibility in oxidizing and reducing conditions is required for a successful application in symmetric and reversible SOFCs (SR-SOFCs). Therefore, we investigated the structural behaviour of the composite under oscillating $\mathrm{H}_{2} / \mathrm{O}_{2}$ feed.

\section{Experimental}

\subsection{Synthesis}

The nanocomposites $\mathrm{CuO} / \mathrm{CGO}\left(\mathrm{CGO}=\mathrm{Ce}_{0.9} \mathrm{Gd}_{0.1} \mathrm{O}_{1.95} \mathrm{CuO}\right.$ :CGO10 2:3) were obtained by the citrate method [7] starting from CGO, (Sigma-Aldrich >99\%, dimension 5-10nm), and $\mathrm{CuO}$ (Sigma-Aldrich 98\%, dimension $<5 \mu \mathrm{m}$ ). Citric acid monohydrate (Sigma Aldrich >99\%) was added to an aqueous solution of the copper cations, obtained by mineralization of $\mathrm{CuO}$ with nitric acid, with a molar ratio of 1.9:1 with respect to the total amount of cations. Before adding CGO powder to the solution, the $\mathrm{pH}$ was adjust to reach respectively 1,4 and 8 obtaining three different solutions from whom a different complexation and final particles' dispersion is expected (the final samples will hereafter indicated as $\mathrm{pH} 1, \mathrm{pH} 4$, and $\mathrm{pH} 8$ ). Each solution was than heated to $80^{\circ} \mathrm{C}$ in air to promote water evaporation and to obtain a wet-gel. The gels were heated in air to $400^{\circ} \mathrm{C}\left(5^{\circ} \mathrm{C} / \mathrm{min}\right.$ heating rate) for $2 \mathrm{~h}$ to decompose the organic framework. At the end of the heat treatment, the powders were grinded and calcined at $600^{\circ} \mathrm{C}$ for $5 \mathrm{~h}$. This procedure was preferred to the traditional wet impregnation to allow the deposition of copper oxide in highly dispersed form thanks to the complexation of the citrate. 
$10^{\mathrm{TH}}$ INTERNATIONAL CONFERENCE ON SUSTAINABLE ENERGY AND ENVIRONMENTAL Protection (June $27^{\mathrm{TH}}-30^{\mathrm{TH}}, 2017$, Bled, Slovenia), ENERGy StORAGE

T. Wilberforce, F. N. Khatib, A. Al Makky, A. Baroutaji \& A.G. Olabi: Characterisation of Proton Exchange Membrane (PEMFC) Fuel Cell Through Design of Experiment

(DOE)

\subsection{Characterization}

XPS measurements were carried out with a Perkin Elmer $\Phi$ 5600ci Multi Technique System. The spectrometer was calibrated by assuming the binding energy (BE) of the Au $4 \mathrm{f}_{7 / 2}$ line to be $84.0 \mathrm{eV}$ with respect to the Fermi level. Both extended spectra (survey $187.85 \mathrm{eV}$ pass energy, $0.5 \mathrm{eV} \cdot \mathrm{step}^{-1}, 0.05 \mathrm{~s} \cdot \mathrm{step}^{-1}$ ) and detailed spectra (Ce 3d, Gd 4d, $\mathrm{Cu} 2 \mathrm{p}, \mathrm{O} 1 \mathrm{~s}$ and $\mathrm{C} 1 \mathrm{~s}-23.5 \mathrm{eV}$ pass energy, $0.1 \mathrm{eV} \cdot \mathrm{step}^{-1}, 0.1 \mathrm{~s} \cdot \mathrm{step}^{-1}$ ) were collected with a standard $\mathrm{Al} \mathrm{K} \alpha$ source. The atomic percentage was evaluated using the PHI sensitivity factors [8] after a Shirley-type background subtraction [9]. The peak positions were corrected for the charging effects by considering the $\mathrm{C} 1 \mathrm{~s}$ peak at $285.0 \mathrm{eV}$ and evaluating the BE differences [10]. XRD analyses were performed with a Bruker D8 Advance diffractometer with Bragg-Brentano geometry using a $\mathrm{Cu} \mathrm{K} \alpha$ radiation $(40 \mathrm{kV}$, $40 \mathrm{~mA}, \lambda=0.154 \mathrm{~nm}$ ). Temperature Programmed Reduction (TPR) measurements were performed with an Autochem II 2920 Micromeritics, equipped with a TCD detector. TPR measurements were carried out in a quartz reactor using $50 \mathrm{mg}$ of the sample and heating from RT to $900^{\circ} \mathrm{C}$ at $10^{\circ} \mathrm{C} / \mathrm{min}$ under a constant flow of $5 \mathrm{vol} \% \mathrm{H}_{2} / \mathrm{Ar}(50 \mathrm{ml} / \mathrm{min})$. Field emission-scanning electron microscopy and EDX measures were carried on a Zeiss SUPRA 40VP. Morphological analysis and EDX analysis were carried out setting the acceleration voltages at $20 \mathrm{kV}$.

\subsection{Catalytic tests}

The catalytic tests were carried out by loading the sample in a quartz tube reactor in which a thermocouple was inserted to read and control the temperature. The effluent gases from the reactor reached the GC (Agilent 7890A equipped with TCD) for the analysis. Methane oxidation was performed between RT and $900^{\circ} \mathrm{C}$ using stoichiometric mixtures $(2 \mathrm{vol} \%$ $\mathrm{CH}_{4}$ and 4 vol\% $\mathrm{O}_{2}$ ).

\section{Time resolved operando XRD}

Time-resolved operando XRD measurements were performed at beamline ID 15 of the European Synchrotron Research Facility (ESRF, Grenoble) in the Q range of 0-12 $\AA^{-1}$ and at an energy of $74.9 \mathrm{keV}$. The patterns were collected every $0.5 \mathrm{~s}$ during the heating ramp and at static temperatures. Alternate pulses (20 s) of $5 \mathrm{vol} \% \mathrm{H}_{2} / \mathrm{Ar}$ and $5 \mathrm{vol} \%$ $\mathrm{O}_{2} / \mathrm{Ar}$ were performed in a home-made cell closed by X-ray transparent windows (graphite) and interfaced with a mass spectrometer [11].

\subsection{Electrochemical characterization}

The electrochemical measurements were performed using symmetric cells $(\mathrm{Cu} / \mathrm{CGO} / \mathrm{CGO} / \mathrm{Cu} / \mathrm{CGO})$ made of dense gadolinium doped ceria $(\mathrm{CGO})$ ceramics as electrolyte on which electrode materials based on the as prepared $\mathrm{CuO} / \mathrm{CGO}$ powder were deposited as porous layers [12] and reduced by treating in $5 \% \mathrm{H}_{2}$ at $400^{\circ} \mathrm{C}$ for $1 \mathrm{~h}$. The electrolyte was made with a pellet pressed and then calcined at $1450^{\circ} \mathrm{C}$ for $5 \mathrm{~h}$ with a 
$10^{\text {TH }}$ International Conference on Sustainable Energy and Environmental Protection (June $27^{\mathrm{TH}}-30^{\mathrm{TH}}, 2017$, Bled, Slovenia), Hydrogen and Fuel Cells

G. Carollo, A. Garbujo, D. Ferri, M. M. Natile \& A. Glisenti: Cu/CGO Cermet Based Electrodes for Symmetric and Reversible Solid Oxide Fuel Cells

$1.5^{\circ} \mathrm{C} /$ min heating ramp. The symmetric electrode was deposited by a home-made screen printing machine and calcined on the electrolyte at $1000^{\circ} \mathrm{C}$ for $1 \mathrm{~h}$ with a $2^{\circ} \mathrm{C} /$ min heating ramp. After calcination the electrode's thickness was about $10 \mu \mathrm{m}$, as show in Figure 1.

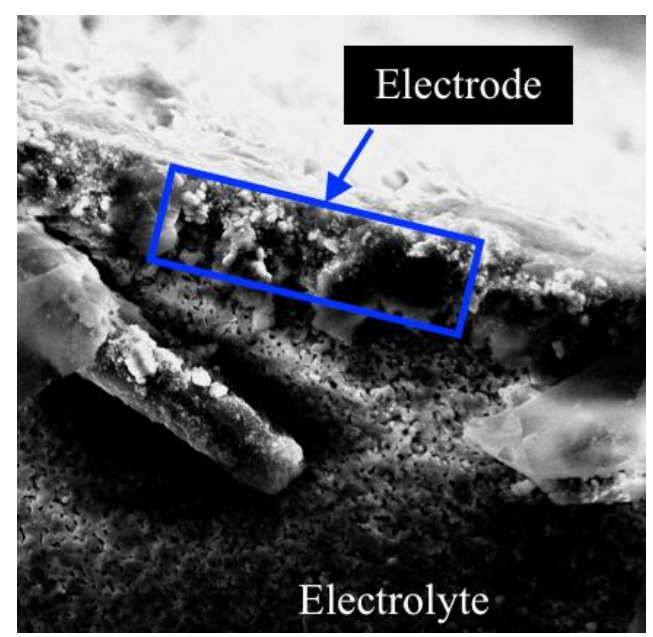

Figure 1. SEM image of cell's section .

Electrochemical Impedance Spectroscopy (EIS) measurements were carried out using an Autolab Frequency Response Analyser. The frequency scanned was from $0.05 \mathrm{~Hz}$ to 1.5 $\mathrm{MHz}$ and the amplitude of $0.05 \mathrm{~V}$.

\section{$3 \quad$ Results}

\subsection{XRD}

The comparison between the XRD patterns of $\mathrm{CuO} / \mathrm{CGO}$ and $\mathrm{CGO}$ revealed the formation of cubic $\mathrm{CuO}$ (Figure 2). No significant differences have been observed as a function of the $\mathrm{pH}$ of the precursors' solution. 
T. Wilberforce, F. N. Khatib, A. Al Makky, A. Baroutaji \& A.G. Olabi: Characterisation of Proton Exchange Membrane (PEMFC) Fuel Cell Through Design of Experiment

(DOE)

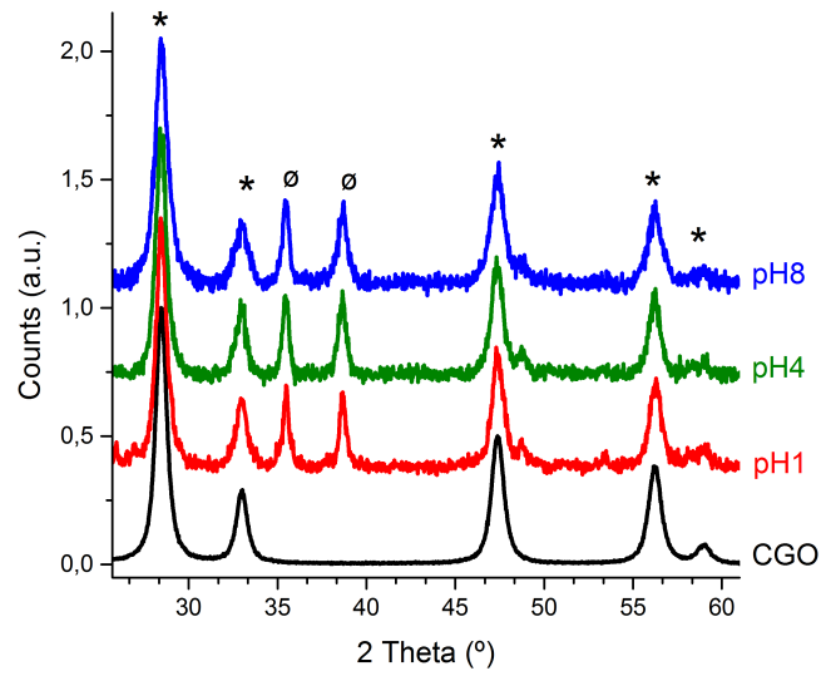

Figure 2. XRD patterns of the $\mathrm{CuO} / \mathrm{CGO}$ nanocomposites obtained at increasing $\mathrm{pH}$ from bottom to top: $\mathrm{pH} 1=$ red, $\mathrm{pH} 4=$ green, $\mathrm{pH} 8=$ blue. Symbols: [*] CGO, [ø] CuO.

The pattern of CGO is reported for comparison (black line).

\subsection{XPS}

The $\mathrm{Cu} 2 \mathrm{p}_{3 / 2}$ peak position (934.1 eV) was consistent with those expected for $\mathrm{Cu}$ (II) [13]. Consistently, the shake up signal (about $942 \mathrm{eV}$ ) characteristic of $\mathrm{Cu}(\mathrm{II})$ was evident. No significant difference was observed in the $\mathrm{Ce} 3 \mathrm{~d}$ signals after copper deposition. The atomic surface compositions indicated a low amount of copper suggesting high $\mathrm{CuO}$ dispersion particles.

Table 1. XPS atomic compositions before and after the deposition of copper under different synthesis conditions

\begin{tabular}{|c|c|c|c|c|c|c|c|}
\hline \begin{tabular}{|l|} 
Sample \\
\end{tabular} & & $\mathrm{Ce}$ & $\mathrm{Gd}$ & $\mathrm{Cu}$ & $\mathrm{O}$ & $\mathrm{Gd} / \mathrm{C}$ & $\mathrm{Cu} / \mathrm{C}_{\mathrm{e}}$ \\
\hline CGO10 & XPS & $\begin{array}{l}31.5 \\
(92.1\end{array}$ & \begin{tabular}{|l|}
2.7 \\
$(7.9)$
\end{tabular} & - & 65.8 & 0.1 & - \\
\hline & Nomina & $\begin{array}{l}30.5 \\
(90.0\end{array}$ & \begin{tabular}{|l|}
3.4 \\
$(10.0$ \\
\end{tabular} & - & 66.1 & 0.1 & - \\
\hline $\begin{array}{l}\mathrm{CuO}_{\mathrm{x}} / \mathrm{CGO} 1 \\
\mathrm{pH} 1\end{array}$ & XPS & $\begin{array}{l}22.9 \\
(55.1 \\
\end{array}$ & \begin{tabular}{|l|}
2.4 \\
$(5.7)$ \\
\end{tabular} & \begin{tabular}{|l|}
16.3 \\
$(39.2)$ \\
\end{tabular} & 58.4 & 0.1 & 0.7 \\
\hline $\begin{array}{l}\mathrm{CuO}_{\mathrm{x}} / \mathrm{CGO} 1 \\
\mathrm{pH} 8\end{array}$ & XPS & $\begin{array}{l}16.3 \\
(35.0\end{array}$ & \begin{tabular}{|l|}
8.8 \\
$(18.9$ \\
\end{tabular} & \begin{tabular}{l|}
21.5 \\
$(46.1)$
\end{tabular} & 53.4 & 0.5 & 1.3 \\
\hline $\mathrm{CuO}_{\mathrm{x}} / \mathrm{CGO} 1$ & Nomina & $\begin{array}{l}15.4 \\
(36.7 \\
\end{array}$ & \begin{tabular}{|l|}
1.7 \\
$(4.1)$ \\
\end{tabular} & \begin{tabular}{|l|}
24.8 \\
$(59.2)$ \\
\end{tabular} & 58.1 & 0.1 & 1.6 \\
\hline
\end{tabular}


$10^{\mathrm{TH}}$ International CONFERENCE ON Sustainable EnERgy AND ENVIRONMENTAL Protection (June $27^{\mathrm{TH}}-30^{\mathrm{TH}}, 2017$, Bled, Slovenia), Hydrogen and Fuel Cells G. Carollo, A. Garbujo, D. Ferri, M. M. Natile \& A. Glisenti: Cu/CGO Cermet Based Electrodes for Symmetric and Reversible Solid Oxide Fuel Cells

\subsection{TPR}

The TPR curves of as prepared $\mathrm{CuO} / \mathrm{CGO}$ samples (Figure 3) exhibited a signal due to the $\mathrm{Cu}(\mathrm{II}) \rightarrow \mathrm{Cu}(0)$ reduction at ca. $250^{\circ} \mathrm{C}$. The corresponding signal in the $\mathrm{CuO}$ reference was observed at $316^{\circ} \mathrm{C}$. The lower reduction temperature was consistent with the extent of dispersion of $\mathrm{CuO}$ [14]. A weak shoulder at low temperature $\left(180-200^{\circ} \mathrm{C}\right)$, becoming more evident as the synthesis $\mathrm{pH}$ increases, suggested the presence of highly dispersed nanoparticles.

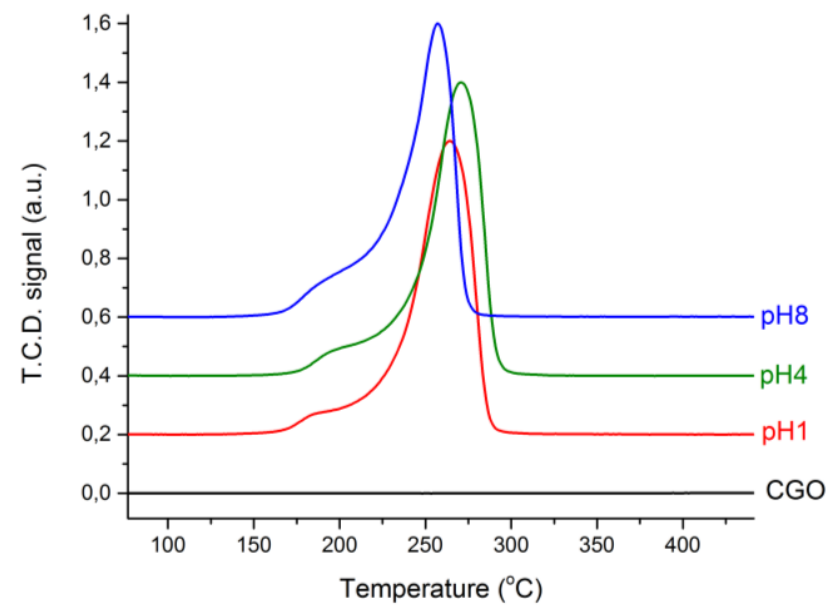

Figure 3. TPR curves of the $\mathrm{CuO} / \mathrm{CGO}$ nanocomposites obtained at increasing $\mathrm{pH}$ from bottom to top: $\mathrm{pH} 1=$ red, $\mathrm{pH} 4=$ green, $\mathrm{pH} 8=$ blue. The line of $\mathrm{CGO}$ is reported for comparison (black line).

This important result confirmed the possibility to obtain highly dispersed particles by opportunely modifying the citrate synthesis procedure.

The comparison between the estimated $\left(123 \mathrm{~cm}^{3} / \mathrm{g}\right)$ and measured $\left(123 \mathrm{~cm}^{3} / \mathrm{g}\right.$ for all the three samples) $\mathrm{H}_{2}$ consumption confirmed that copper is present as $\mathrm{Cu}(\mathrm{II})$. It was interesting to observe that, based on literature, pure $\mathrm{CeO}_{2}$ exhibits two reduction peaks at 450 and $900{ }^{\circ} \mathrm{C}$, whereas in mixed $\mathrm{CuCe}$ oxide catalysts the ceria reduction is frequently difficult to observe and can be centred at lower temperatures [15]. In the present case no relevant reduction events were observed for $\mathrm{CGO}$ until $900^{\circ} \mathrm{C}$ testifying its great stability under reducing conditions.

\subsection{SEM}

TPR results suggest a different dispersion of $\mathrm{CuO}$ depending on the $\mathrm{pH}$ of the precursors' solutions. This behaviour is confirmed by SEM images. When the $\mathrm{pH}=1$, in fact, it was 
$10^{\mathrm{TH}}$ INTERNATIONAL CONFERENCE ON SUSTAINABLE ENERGY AND ENVIRONMENTAL 59 Protection (June $27^{\mathrm{TH}}-30^{\mathrm{TH}}, 2017$, Bled, Slovenia), ENERGy StORAGE

T. Wilberforce, F. N. Khatib, A. Al Makky, A. Baroutaji \& A.G. Olabi: Characterisation of Proton Exchange Membrane (PEMFC) Fuel Cell Through Design of Experiment

(DOE)

possible to observe the $\mathrm{CuO}$ agglomerate inhomogeneous dispersed on the surface. The $\mathrm{CuO}$ particle size obtained were more than $1 \mu \mathrm{m}$. As expected at $\mathrm{pH} 8$, the copper complexation induced grater dispersion with smaller particles size, $<1 \mu \mathrm{m}$ (Figure 4 and Figure 5).

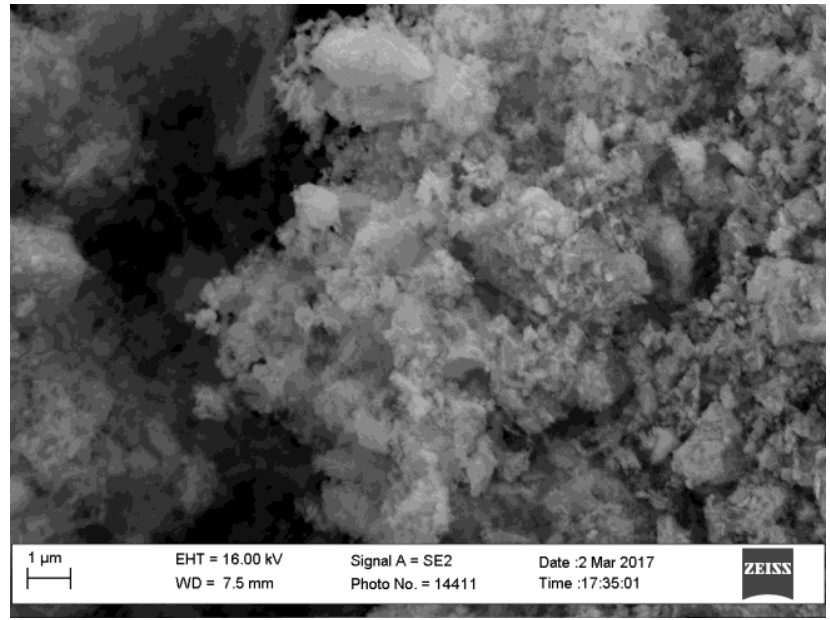

Figure 4. SEM image of the $\mathrm{CuO} / \mathrm{CGO} \mathrm{pH} 8$ powder.

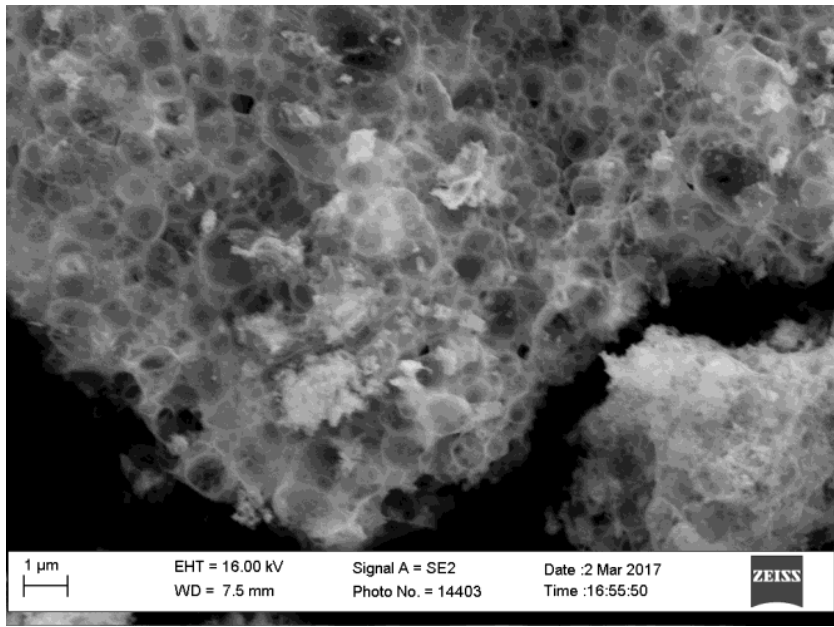

Figure 5. SEM image of the $\mathrm{CuO} / \mathrm{CGO} \mathrm{pH} 1$ powder.

\subsection{Catalytic and electrocatalytic tests}

The catalytic behaviour observed before and after the deposition of copper oxide is reported in Figure 6. 

Protection (June $27^{\mathrm{TH}}-30^{\mathrm{TH}}, 2017$, Bled, Slovenia), Hydrogen and Fuel Cells G. Carollo, A. Garbujo, D. Ferri, M. M. Natile \& A. Glisenti: Cu/CGO Cermet Based Electrodes for Symmetric and Reversible Solid Oxide Fuel Cells

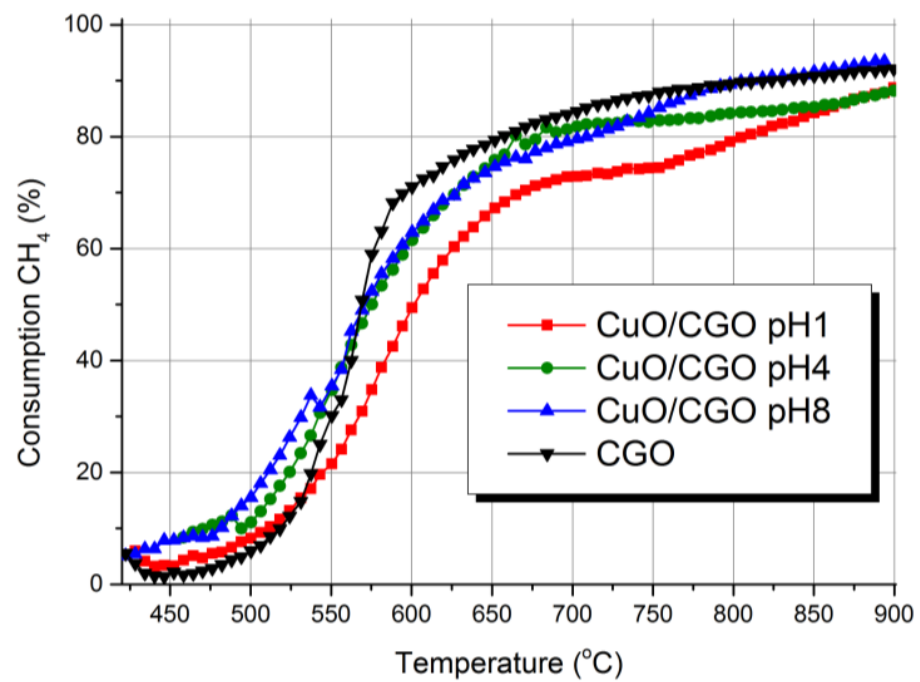

Figure 6. Catalytic activity in methane oxidation observed for the CGO before and after copper oxide deposition.

The CGO support started to be active in methane oxidation at $475^{\circ} \mathrm{C}$; the $\mathrm{T}_{50}$ was $575^{\circ} \mathrm{C}$ and a conversion of more than $80 \%$ was reached at $650^{\circ} \mathrm{C}$. In the temperature range more interesting for the application in SOFCs $\left(600-800^{\circ} \mathrm{C}\right)$ the CGO showed good catalytic activity. Moreover, CGO was also selective towards the complete oxidation. The deposition of $\mathrm{CuO}$ did not decrease the catalytic activity significantly: the catalytic activity decreased only in the nanocomposite obtained at $\mathrm{pH}=1\left(\mathrm{~T}_{50}=600^{\circ} \mathrm{C} ; 80 \%\right.$ conversion at $800^{\circ} \mathrm{C}$ ). 
T. Wilberforce, F. N. Khatib, A. Al Makky, A. Baroutaji \& A.G. Olabi: Characterisation of Proton Exchange Membrane (PEMFC) Fuel Cell Through Design of Experiment

(DOE)

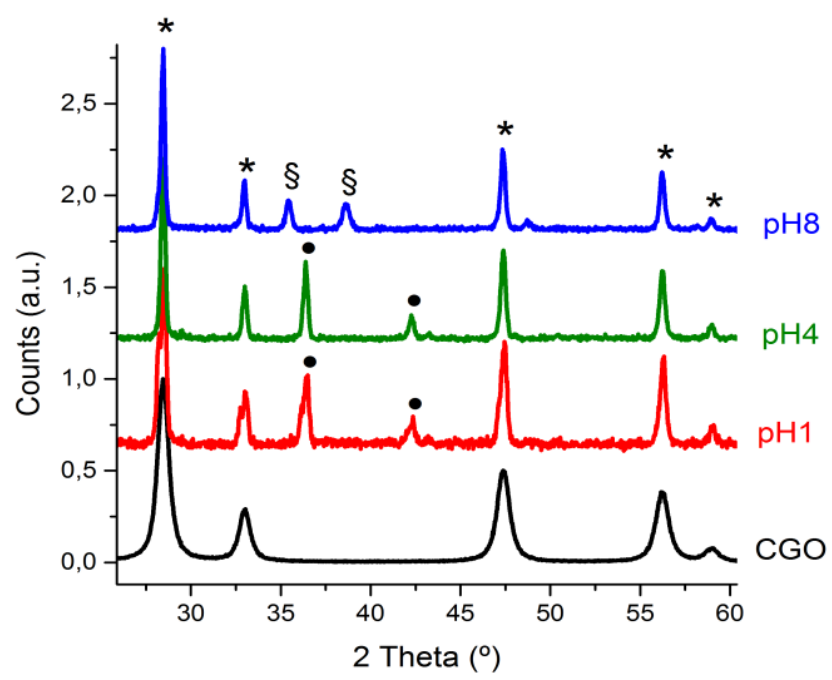

Figure 7. XRD patterns of the $\mathrm{CuO} / \mathrm{CGO}$ nanocomposites obtained at increasing $\mathrm{pH}$ (from bottom to top) after reaction. Symbols: $\left[{ }^{*}\right] \mathrm{CGO},[\S] \mathrm{CuO},[\bullet] \mathrm{Cu}$. The pattern of $\mathrm{CGO}$ is reported for comparison (black line).

The XRD patterns obtained for the samples after the reaction are compared in Figure 7. In all cases the XRD signals were characterized by a smaller FWHM suggesting the increment of the crystallite size. A different behaviour was observed between the composite obtained at $\mathrm{pH}=8$ and those prepared at $\mathrm{pH}=1$ and 4 . In the former, the increase of the crystallite size was the only observed difference, whereas in the latter two nanocomposites copper was converted into elemental form. These results suggest that the synthesis at $\mathrm{pH}=8$ allows to reach a better dispersion of the $\mathrm{CuO}$ nanoparticles enhancing the stability of the composite.

The high dispersion of copper also improves the electrochemical performance as a consequence of the enhanced electrical conductivity: EIS measurements, in fact, confirm that the Area Specific Resistance (ASR) significantly decreases due to copper dispersion and as a function of temperature. The Nyquist plot analysis allowed to distinguish between the different contributions to the resistance and thus to optimize the electrode preparation.

\subsection{Time-resolved XRD}

The behaviour under reducing conditions was investigated in more detail by collecting time-resolved XRD patterns. The continuous perturbation of the sample by alternated gas pulses requires high time resolution to obtain kinetic information concerning the structural changes. The data collected in temperature ramp from the sample prepared at $\mathrm{pH}=8$ (Figure 8 ) showed the reduction of $\mathrm{CuO}$ to $\mathrm{Cu}$ through the path $\mathrm{CuO}-\mathrm{Cu}_{2} \mathrm{O}-\mathrm{Cu}$ at 
$10^{\mathrm{TH}}$ International Conference on Sustainable EnERgy and Environmental Protection (June $27^{\mathrm{TH}}-30^{\mathrm{TH}}, 2017$, Bled, Slovenia), Hydrogen and Fuel Cells G. Carollo, A. Garbujo, D. Ferri, M. M. Natile \& A. Glisenti: Cu/CGO Cermet Based Electrodes for Symmetric and Reversible Solid Oxide Fuel Cells

about $250^{\circ} \mathrm{C}$ as expected from TPR analysis (Figure 3). The $\mathrm{Cu}_{2} \mathrm{O}$ XRD contribution at $2.55 \AA^{-1}$ appeared clearly at ca. $190^{\circ} \mathrm{C}$ while the $\mathrm{CuO}$ phase gradually disappeared. $\mathrm{Cu}_{2} \mathrm{O}$ was only formed transiently from $157^{\circ} \mathrm{C}$ to $183^{\circ} \mathrm{C}$. When the $\mathrm{Cu} \mathrm{XRD}$ phase started to appear, the $\mathrm{CuO}$ and $\mathrm{Cu}_{2} \mathrm{O}$ phases vanished simultaneously.

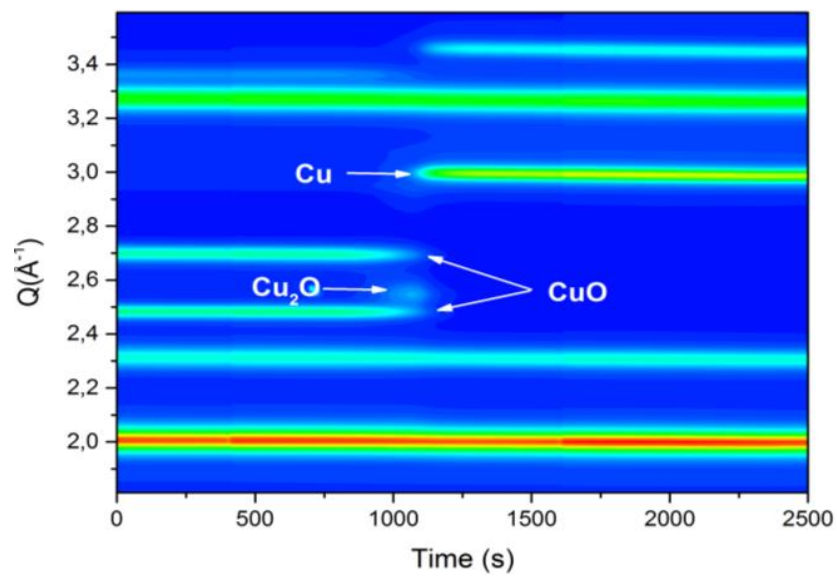

Figure 8. 2D visualization of the operando XRD data acquired during the heating ramp $\left(50^{\circ} \mathrm{C}-400^{\circ} \mathrm{C}\right)$ under $5 \mathrm{vol} \% \mathrm{H}_{2} / \mathrm{Ar}$ flow. Time-resolution: $0.5 \mathrm{~s}$.

Redox pulses of diluted $\mathrm{H}_{2}$ and $\mathrm{O}_{2}$ were performed at $400^{\circ} \mathrm{C}$. The phase transitions were followed at $0.5 \mathrm{~s} /$ pattern (Figure 9) and the products were detected with a mass spectrometer.

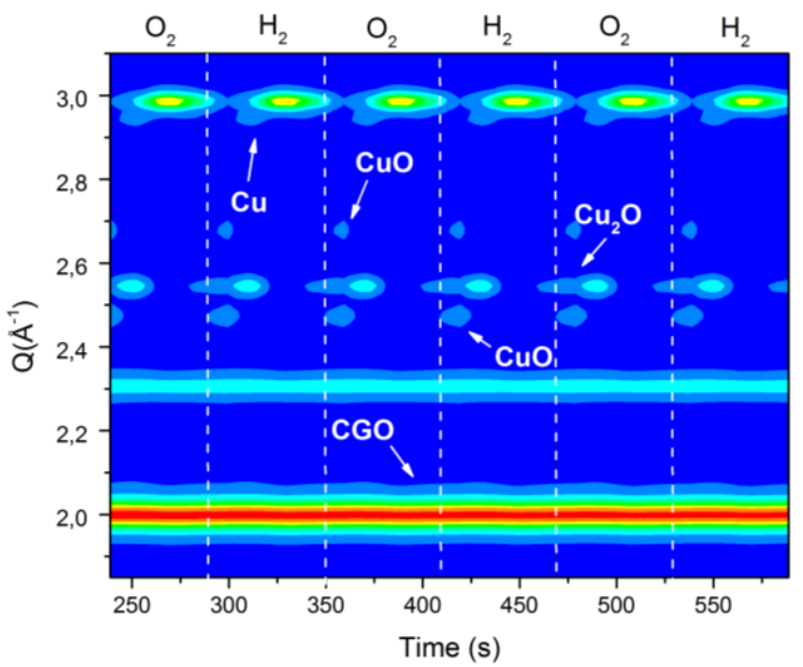

Figure 9. 2D visualization of the operando XRD data acquired during repeated and consecutive pulses of $5 \mathrm{vol} \% \mathrm{H}_{2} / \mathrm{Ar}$ and $5 \mathrm{vol} \% \mathrm{O}_{2} / \mathrm{Ar}$ at $400^{\circ} \mathrm{C}$. 

Protection (June $27^{\mathrm{TH}}-30^{\mathrm{TH}}, 2017$, Bled, SLOVEnia), EnERgy Storage

T. Wilberforce, F. N. Khatib, A. Al Makky, A. Baroutaji \& A.G. Olabi: Characterisation of Proton Exchange Membrane (PEMFC) Fuel Cell Through Design of Experiment

(DOE)

As expected, the mass analysis revealed the formation of water as product when the sample was in reducing environment. During the redox pulsing, the copper dispersed on the $\mathrm{CGO}$ surface changed repeatedly and reversibly from $\mathrm{CuO}$ to $\mathrm{Cu}$ through $\mathrm{Cu}_{2} \mathrm{O}$ in the $\mathrm{H}_{2}$ pulse and re-oxidized reversibly in the $\mathrm{O}_{2}$ pulse. The main XRD reflex of the CGO phase also exhibited a reversible change of $\mathrm{d}$ spacing in the reductive and oxidative pulses suggesting a reversible expansion/contraction of the CGO lattice upon oxygen exchange with the environment but without loss of the structure.

\section{Conclusions}

In this contribution we developed a new procedure for the dispersion of copper oxide on CGO. We observed that the copper distribution can be controlled through the appropriate selection of the synthesis conditions. The highly dispersed copper enhances electron conductivity without decreasing the catalytic performance of CGO. The structural behaviour observed by operando time-resolved XRD confirms the stability and reversibility of the cermet under reducing and oxidising condition, and therefore the possibility to use this material as electrode in intermediate temperature Solid Oxide Fuel Cells.

\section{Acknowledgements}

We acknowledge the financial support of the European Union's H2020 grant agreement no 686086PARTIAL PGMs.

We acknowledge the European Synchrotron Radiation Facility for beamtime allocation at beamline ID15 and Dr. M. Di Michiel for assistance with the measurements.

We also acknowledge Stefano Mercanzin and Lorenzo Dainese for their contribution in realizing the device used in this project for electrochemical measures.

\section{References}

[1] S. Mc Intosh, R. J. Gorte; Chem. Rev. 104 (2004) 4845

[2] 2 S. Park, R. J. Gorte, J.M. Vohs; Applications of heterogeneous catalysis in the direct oxidation of hydrocarbons in a solid-oxide fuel cell; Appl. Catal. A. Gen. 200 (2000) 5561 ;

[3] A. Hornés, D. Gamarra, G. Munuera, J.C. Conesa, A. Martinez-Arias; Catalytic properties of monometallic copper and bimetallic copper-nickel systems combined with ceria and Ce$\mathrm{X}(\mathrm{X}=\mathrm{Gd}, \mathrm{Tb})$ mixed oxides applicable as SOFC anodes for direct oxidation of methane; J. Power Sources 169 (2007) 9-16;

[4] N.E. Kiratzis, P. Connor, J.T.S. Irvine; Preparation and characterization of copper based cermet anodes for use in solid oxide fuel cells at intermediate temperatures; J. Electroceram. 24 (2010) 270-287;

[5] J.J. Lee, E. W. Park, S.-H. Hyun; Performance and evaluation of Cu-based nanocomposite anodes for direct utilization of hydrocarbon fuels in SOFCs; Fuel Cells 10 (2010) 145-155; 
$10^{\text {Th }}$ International Conference on Sustainable Energy and Environmental Protection (June $27^{\mathrm{TH}}-30^{\mathrm{TH}}, 2017$, Bled, Slovenia), Hydrogen and Fuel Cells G. Carollo, A. Garbujo, D. Ferri, M. M. Natile \& A. Glisenti: Cu/CGO Cermet Based Electrodes for Symmetric and Reversible Solid Oxide Fuel Cells

[6] J. Marrero-Jerez, E. Chinarro, B. Moreno, J. Peña-Martínez, P. Núñez; CGO20-CuO composites synthesized by the combustion method and characterized by H2-TPR Ceram. Int. 41 (2015) 10904-10909

[7] C. Marcilly, P. Courty, B. Delmon, Preparation of Highly Dispersed Mixed Oxides and Oxide Solid Solutions by Pyrolysis of Amorphous Organic Precursors J. Am. Ceram. Soc. 53 (1970) 56-57.

[8] J.F. Moulder, W.F. Stickle, P.E. Sobol, K.D. Bomben, Handbook of X-ray Photoelectron Spectroscopy; J. Chastain, Ed., Physical Electronics, Eden Prairie, MN, 1992.

[9] D.A. Shirley, High-Resolution X-Ray Photoemission Spectrum of the Valence Bands of Gold Phys. Rev. B 5 (1972) 4709-4714.

[10] D. Briggs, J.C. Riviere, in: D. Briggs, M.P. Seah (Eds.), Practical Surface Analysis, Wiley, New York, 1983.

[11] G.L. Chiarello, M. Nachtegaal, V. Marchionni, L. Quaroni, D. Ferri, Rev. Sci. Instrum. 85 (2014) 074102.

[12] M.M. Natile, G. Eger, P. Batocchi, F. Mauvy, A. Glisenti; Strontium and copper doped $\mathrm{LaCoO}_{3}$ : New cathode materials for solid oxide fuel cells? International Journal of Hydrogen Energy 42 (2017) 1724-1735.

[13] NIST XPS Database 20, Version 3.4 (Web Version)

[14] G. Perin, J. Fabro, M. Guiotto, Q. Xin, M.M. Natile, P. Cool, P. Canu, A. Glisenti; $\mathrm{Cu} @ \mathrm{LaNiO}_{3}$ based nanocomposites in TWC applications. App. Catal. B Environ. 209 (2017) 214 and references therein.

[15] G. Zhou, H. Lan, T. Gao, H. Xie; Influence of $\mathrm{Ce} / \mathrm{Cu}$ ratio on the performance of ordered mesoporous $\mathrm{CeCu}$ composite oxide catalysts; Chem. Eng. J. 246 (2014) 53-63, and references therein. 
$10^{\mathrm{TH}}$ InTERnational CONFERENCE ON Sustainable ENERgy AND ENVIRONMENTAL Protection (June $27^{\mathrm{TH}}-30^{\mathrm{TH}}$, 2017, Bled, Slovenia), Hydrogen ANd Fuel Cells

J. Krope, A.Ghani Olabi, D. Goričanec \& S. Božičnik

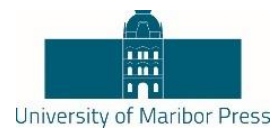

\title{
Improvement of a Hybrid Serpentine-Interdigitated Flow Field by Adjusting Numbers of Inlet and Outlet of Gas Flow Channels
}

\author{
NUTTAPOL LIMJEERAJARUS \& THATPHONG SANTIPRASERTKUL
}

\begin{abstract}
In our previous work, a novel flow field design so-called "Hybrid Serpentine-Interdigitated (HSI)" had been proposed. Although it was very promising in terms of performance and pressure drop, it still had the low oxygen concentration area. To improve its performance, three HSI configurations with different numbers of gas inlet and outlet, namely one inlet and one outlet HIS (1-IO HIS), one inlet and two outlets HIS (1I-2O HIS) and two inlets and two outlets HIS (2-IO HIS) were numerically investigated. The investigation on the cell performance and other transport behaviors has been carried out using CFD techniques via ANSYS FLUENT software. At a practical operating potential of $0.6 \mathrm{~V}$, the simulation results revealed that although the three configurations could equally provide the net power output of about $23.5 \mathrm{~W} / \mathrm{unit}$ cell $(50 \mathrm{~cm} 2)$, the 2 -IO HSI could provide the best distributions of oxygen mass fraction, water content, and water saturation due to the decrease of channel length. These results gave a better understanding that how the configuration of the gas inlet and outlet has a great effect on the efficient operation of the PEFCs which could provide valuable information for further optimizations.
\end{abstract}

Keywords: •PEFC • CFD • Hybrid Serpentine-Interdigitated Flow Field • Number of Gas Flow Channel • HIS •

CoRRESPONDENCE AdDRESS: Nuttapol Limjeerajarus, Ph.D., Associate Professor, Thai-Nichi Institute of Technology, Faculty of Engineering, Research Center for Advanced Energy Technology, 1771/1 Pattanakarn, Suan Luang, Bangkok 10250, Thailand, e-mail: nuttapol@tni.ac.th. Thatphong Santiprasertkul, Thai-Nichi Institute of Technology, Faculty of Engineering, Automotive Engineering Program, 1771/1 Pattanakarn, Suan Luang, Bangkok 10250, Thailand, e-mail: sa.thatphong_st@tni.ac.th. 
$10^{\mathrm{TH}}$ InTERnAtional CONFERENCE ON Sustainable ENERGy AND ENVIRONMENTAL Protection (June $27^{\mathrm{TH}}-30^{\mathrm{TH}}, 2017$, Bled, Slovenia), Hydrogen and Fuel Cells N. Limjeerajarus \& T. Santiprasertkul: Improvement of a Hybrid SerpentineInterdigitated Flow Field by Adjusting Numbers of Inlet and Outlet of Gas Flow Channels

At present, the clean energy research has been widely studied due to the increase of environmental pollution and the depletion of fossil fuel reserves. Many research focused on the enhancement of the use of renewable energy technologies (RETs) [1,2]. Among various RETs, the Polymer Electrolyte fuel cell (PEFC) is one of the most favored energy convertors due to its low operating temperature, high power density, low noise and zerocarbon emission. To enhance the performance of a PEFC, a proper design of the reactant flow fields is required as the flow fields performed several functions affecting the cell performance, such as distributing reactant to the diffusion and catalyst layers, conducting the electrons to the external circuit, keeping the reactants (i.e., $\mathrm{H}_{2}$ and $\mathrm{O}_{2}$ ) separated from each other, and also helping in water management [3]. According to our previous study [4], a novel design so-called "Hybrid Serpentine-Interdigitated (HSI) Flow Field" had been proposed and compared with the conventional single-channel serpentine flow field. The result revealed that the HSI flow field with one inlet and one outlet (1-IO HIS) outperformed the single channel serpentine flow field by providing the better heat and water management as well as the net power output. However, the 1-IO HIS flow field still had the shortcoming which was the low oxygen concentration area near the oxygen outlet on the cathode side. The low oxygen concentration reflected low chemical reaction rate and high amount of liquid water in this area. Therefore the 1-IO HSI flow field still needs to be improved. The solution for the improvement of oxygen mass faction distribution was numerical investigated by Seungjae Lee et al. [5]. The result was very useful since the proposed multi-inlet serpentine design achieved more uniform oxygen concentration and water distribution than the conventional single-channel serpentine flow field. In this work, a comparison of the three different cases of the $50 \mathrm{~cm}^{2}$ HSI flow field has been numerically studied. These cases were one inlet and one outlet hybrid serpentine-interdigitated flow field (1-IO HSI), one inlet and two outlets hybrid serpentine-interdigitated flow field (1I-2O HSI) and 2 inlets and 2 outlets hybrid serpentine-interdigitated flow field (2-IO HSI), as depicted in Fig. 1. The transport behaviors such as the oxygen mass fraction, water saturation and water content were also simulated so as to investigate the effect of the numbers of inlet/outlet design.

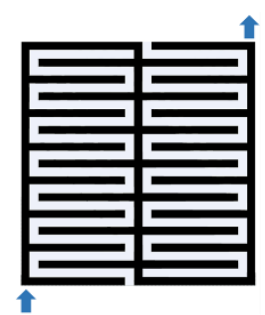

(a)

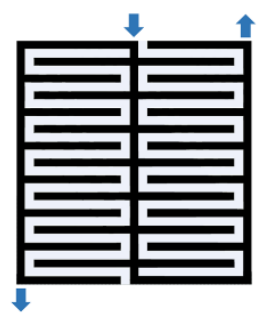

(b)

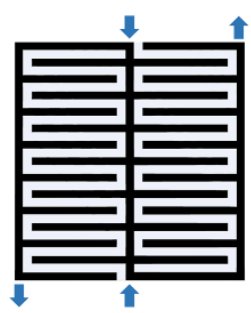

(c)

Figure 1. The three different HIS flow field designs; (a) 1-IO HIS, (b) 1I-2O HIS and (c) 2-IO HSI 
$10^{\mathrm{TH}}$ INTERNATIONAL CONFERENCE ON SUSTAINABLE ENERGY AND ENVIRONMENTAL Protection (June $27^{\mathrm{TH}}-30^{\mathrm{TH}}, 2017$, Bled, SLOVEnia), EnERGy Storage

N. Limjeerajarus \& T. Santiprasertkul: Improvement of a Hybrid SerpentineInterdigitated Flow Field by Adjusting Numbers of Inlet and Outlet of Gas Flow

Channels

\section{$2 \quad$ Model Development}

In this work, the investigation on the cell performance and other transport behaviors of $50 \mathrm{~cm}^{2}$ PEFCs has been carried out using CFD techniques with a finite volume method, including a set of several equations such as the mass conservation equation, the NaviereStoke's equations, the conservation of energy equation, and species transport equations which are a combination of theoretical and experimental derived equations via ANSYS FLUENT software. The 3-D geometries of three HSI configurations were generated in ANSYS WORKBENCH. The geometries' dimension is shown in Table 1. After finishing the geometries, they were imported into ANSYS ICEMCFD for discretizing into small computational cells. To stably solve the problem and avoid inaccurate solution, the hexahedral cells had to be used as they do not create highly skewed cells [6]. There were about 1,500,000 hexahedral cells for each geometry.

The simulation was carried out under the steady state condition and the non-isothermal condition was used to examine the heat generation phenomenon. The inlet flow rates at the anode and the cathode side were assumed constant based on the Reynolds number calculation which were in the laminar flow regime $[3,7]$. 
$10^{\mathrm{TH}}$ InTERnAtional CONFERENCE ON Sustainable EnERgy AND ENVIRONMENTAL Protection (June $27^{\mathrm{TH}}-30^{\mathrm{TH}}, 2017$, Bled, Slovenia), Hydrogen and Fuel Cells

N. Limjeerajarus \& T. Santiprasertkul: Improvement of a Hybrid SerpentineInterdigitated Flow Field by Adjusting Numbers of Inlet and Outlet of Gas Flow Channels

Table 1. Material properties of the flow fields and model parameters used in the simulation [7]

\begin{tabular}{|c|c|c|c|}
\hline Parameter & $1-\mathrm{IO}$ & $1 \mathrm{I}-2 \mathrm{O}$ & $2-\mathrm{IO}$ \\
\hline Number of inlets & 1 & 1 & 2 \\
\hline Number of outlets & 1 & 2 & 2 \\
\hline Cell active area $\left(\mathrm{cm}^{2}\right)$ & \multicolumn{3}{|c|}{48.067} \\
\hline $\begin{array}{l}\text { Channel cross section } \\
\text { (width } \mathrm{x} \text { depth }(\mathrm{mm}) \text { ) }\end{array}$ & \multicolumn{3}{|c|}{$0.80 \times 0.80$} \\
\hline $\begin{array}{l}\text { Porosity; } \\
\text { Gas diffusion layer } \\
\text { Catalyst layer }\end{array}$ & \multicolumn{3}{|c|}{$\begin{array}{l}0.6 \\
0.4\end{array}$} \\
\hline $\begin{array}{l}\text { Electrical conductivity } \\
\left(1 \Omega^{-1} \mathrm{~m}^{-1}\right)\end{array}$ & \multicolumn{3}{|c|}{280} \\
\hline Density $\left(\mathrm{kg} \mathrm{m}^{-3}\right)$ & \multicolumn{3}{|c|}{321.5} \\
\hline $\begin{array}{l}\text { Surface to volume ratio } \\
\left(\mathrm{m}^{2} \mathrm{~m}^{-3}\right)\end{array}$ & \multicolumn{3}{|c|}{$1.127 \times 10^{7}$} \\
\hline $\begin{array}{l}\text { Thermal conductivity } \\
\left(\mathrm{W} \mathrm{m}^{-1} \mathrm{~K}^{-1}\right)\end{array}$ & \multicolumn{3}{|c|}{0.16} \\
\hline $\begin{array}{l}\text { Equivalent weight of dry } \\
\text { membrane } \\
\left(\mathrm{kg} \mathrm{kmol}^{-1}\right)\end{array}$ & \multicolumn{3}{|c|}{1,100} \\
\hline $\begin{array}{l}\text { Anode exchange current } \\
\text { density } \\
\left(\mathrm{A} \mathrm{m}^{-2}\right)\end{array}$ & \multicolumn{3}{|c|}{7.17} \\
\hline $\begin{array}{l}\text { Cathode exchange current } \\
\text { density } \\
\left(\mathrm{A} \mathrm{m}^{-2}\right)\end{array}$ & \multicolumn{3}{|c|}{$7.17 \times 10^{-5}$} \\
\hline Anode flow rate $(\mathrm{kg} / \mathrm{s})$ & \multicolumn{3}{|c|}{$2.87 \times 10^{-6}$} \\
\hline $\begin{array}{l}\text { Cathode flow rate } \\
(\mathrm{ml} / \mathrm{min})\end{array}$ & \multicolumn{3}{|c|}{$3.87 \times 10^{-5}$} \\
\hline
\end{tabular}


$10^{\mathrm{TH}}$ INTERNATIONAL CONFERENCE ON SUSTAINABLE ENERGY AND ENVIRONMENTAL Protection (June $27^{\mathrm{TH}}-30^{\mathrm{TH}}, 2017$, Bled, SLOVEnia), ENERGy StORAGE

N. Limjeerajarus \& T. Santiprasertkul: Improvement of a Hybrid SerpentineInterdigitated Flow Field by Adjusting Numbers of Inlet and Outlet of Gas Flow

Channels

The counter-flow pattern was used in all cases. In each case, the inlet flow rate of each reactant was equivalent to the stoichiometric number of 1.1 at $60^{\circ} \mathrm{C}$ and $90 \% \mathrm{RH}$ which was calculated based on the reference current density of 1.8 $\mathrm{A} \mathrm{cm}^{-2}$. The operating temperature was set at $60^{\circ} \mathrm{C}$ throughout the terminal surface of the anode and cathode current collectors and the pressure was set at $1 \mathrm{~atm}$ at the outlets of the gas flow channel. In this model, water transports inside the membrane, multicomponent diffusion, liquid water formation and transport were considered. The boundary conditions and material properties were obtained from our previous work in which those parameters were already well validated $[7,8]$.

\section{$3 \quad$ Results and Discussion}

After the numerical simulations of the three cases were completed, the I-V polarization and the generated power curves were plotted to compare cell performance, as shown in Fig. 2. The result clearly revealed that the 1I-2O HSI configuration provided the lowest performance as compare with the others, while the highest performance was obtained in the case of 2-IO HSI configuration. From Fig. 2, the maximum generated power by the 2-IO HIS would be at the current density of about $1.6 \mathrm{~A} \mathrm{~cm}^{-2}$, which was at $0.48 \mathrm{~V}$, approximately. However, in many applications, the PEFC usually operates at a particular potential which is approximately $0.6 \mathrm{~V}\left(0.8 \mathrm{~A} \mathrm{~cm}^{-2}\right.$ in this case $)$ [7], Considering at the $0.6 \mathrm{~V}$, the overall performance of 1-IO HSI and 2-IO HSI configurations were almost identical, but that of $1 \mathrm{I}-2 \mathrm{O}$ HIS was significantly lower.

The objective of this work was to investigate not only the cell performance, but also the distributions of water content, water saturation, and the mass fraction of oxygen at the interface of the cathode catalyst layer and gas diffusion layer which was the major disadvantage of the previous HSI flow field (1-IO HSI). The analysis of those distributions was carried out for the practical potential of $0.6 \mathrm{~V}$.

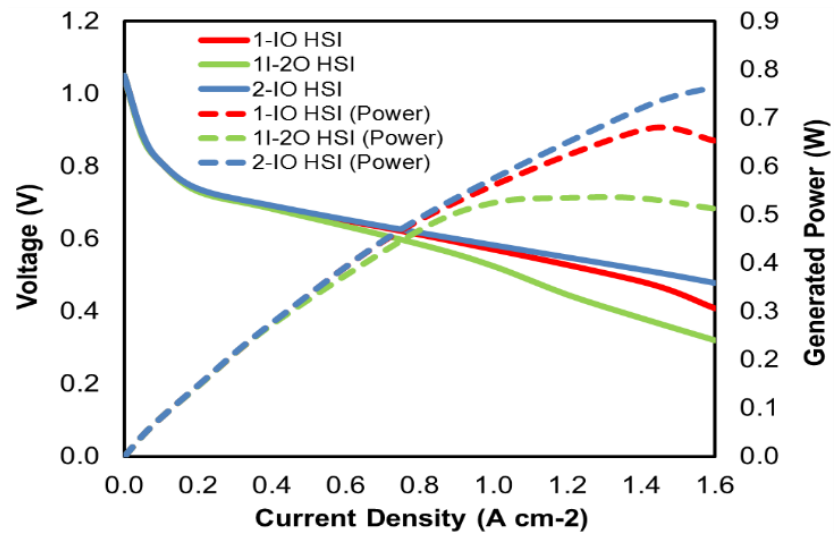

Figure 2. The simulation results of I-V polarization curves and generated power of the three different HIS cases 
$10^{\mathrm{TH}}$ International Conference on Sustainable Energy and Environmental Protection (June $27^{\mathrm{TH}}-30^{\mathrm{TH}}, 2017$, Bled, Slovenia), Hydrogen and Fuel Cells N. Limjeerajarus \& T. Santiprasertkul: Improvement of a Hybrid SerpentineInterdigitated Flow Field by Adjusting Numbers of Inlet and Outlet of Gas Flow Channels

\subsection{Oxygen concentration}

As mentioned earlier, the previous HSI configuration (1-IO HSI) had the weak point which was the low oxygen concentration area near the oxygen outlet on the cathode side (see Fig.3a). This issue could lead to the non-uniform distribution of current density, the acceleration of cell degradation and the decrease in cell durability. The comparison of oxygen mass fraction distribution of the three cases is presented in Fig. 3. The result showed that with the 2-IO and 1I-2O HSI configurations, the oxygen mass fraction around the bottom-right corner was significantly increased, and the distribution of the oxygen mass fraction was obviously more uniform than that in 1-IO HSI case. Furthermore, the 2-IO HSI configuration gave the best uniformity in oxygen mass faction distribution.

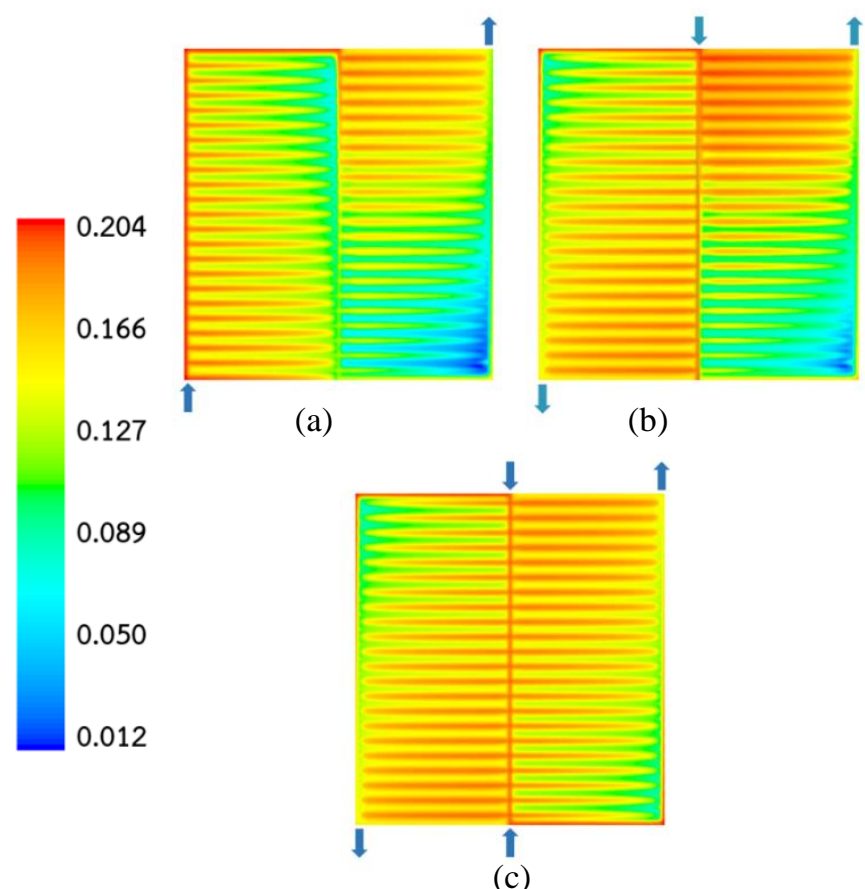

Figure 3. Oxygen mass fraction distribution on the interface between the cathode catalyst and gas diffusion layers of (a) 1-IO HSI (b) 1I-2O HSI (c) 2-IO HSI flow fields

It can imply that oxygen could be better fed into the 1-IO HSI defect point (low oxygen mass fraction area) by increasing the number of gas flow inlet in the middle of the flow field. As a result, at a particular potential below $0.7 \mathrm{~V}$, the current density of the 2-IOHSI configuration was the highest among all three cases because the electrochemical reaction could uniformly occur throughout the entire cell area. This result confirms the summary by Seungjae Lee et al. that increasing inlet of gas flow channel can accomplish 
$10^{\mathrm{TH}}$ INTERNATIONAL CONFERENCE ON SUSTAINABLE ENERGY AND ENVIRONMENTAL Protection (June $27^{\mathrm{TH}}-30^{\mathrm{TH}}, 2017$, Bled, Slovenia), ENERGy StORAGE

N. Limjeerajarus \& T. Santiprasertkul: Improvement of a Hybrid SerpentineInterdigitated Flow Field by Adjusting Numbers of Inlet and Outlet of Gas Flow

Channels

a higher oxygen concentration, which leads to the decrease in the over-potential and ohmic loss, and thus the higher cell performance [3].

\subsection{Water management}

As concluded by many researchers [9], a major problem that affects cell performance and durability is water flooding in the catalyst and gas diffusion layers. Therefore, a welldesigned of flow field must provide a uniform distribution of water concentration and good water management. According to our previous work [2], although 1-IO HSI could provide a better water management than the conventional single channel serpentine flow field, it was not good enough as it caused high membrane water content (water content $>14$ ) which indicated that the membrane was full of liquid water. Fig. 4 presents the comparison of water content distribution of the three cases. It was clear that the 2-IO HSI configuration gave the best water content uniformity while the 1I-2O HSI configuration offered a more uniform water content distribution than the 1-IO HSI configuration. Nevertheless, it is worth to mention that the water content in 2-IO HIS was still higher than 14, which the HIS can be further improved.

Similarly, considering the water saturation distribution on the interface between the cathode catalyst and gas diffusion layers, the 2-IO HSI could offer the best water management while the previous 1-IO HIS gave the worst (see Fig. 5). The 2-IO HIS provided much more uniformity in water saturation distribution than the other two cases. More importantly, the water saturation in 2-IO HIS was below 0.2, which is the critical value suggested the existence of liquid water and the cell performance would become unstable if the water saturation exceeds 0.2. This means the 2-IO HIS could force liquid water out of the cell more efficiently than the 1I-2O HIS and 1-IO HIS, respectively. This resulted from its gas flow inlet and outlet arrangement that reduced the length of the gas flow channels. From Figs. 4 and 5, it can be concluded that the 2-IO HSI configuration provided the best water management in the catalyst layer and the gas diffusion layer as well as in the membrane. 

$10^{\text {Th }}$ International Conference on Sustainable Energy and Environmental Protection (June $27^{\mathrm{TH}}-30^{\mathrm{TH}}, 2017$, Bled, Slovenia), Hydrogen and Fuel Cells N. Limjeerajarus \& T. Santiprasertkul: Improvement of a Hybrid SerpentineInterdigitated Flow Field by Adjusting Numbers of Inlet and Outlet of Gas Flow Channels

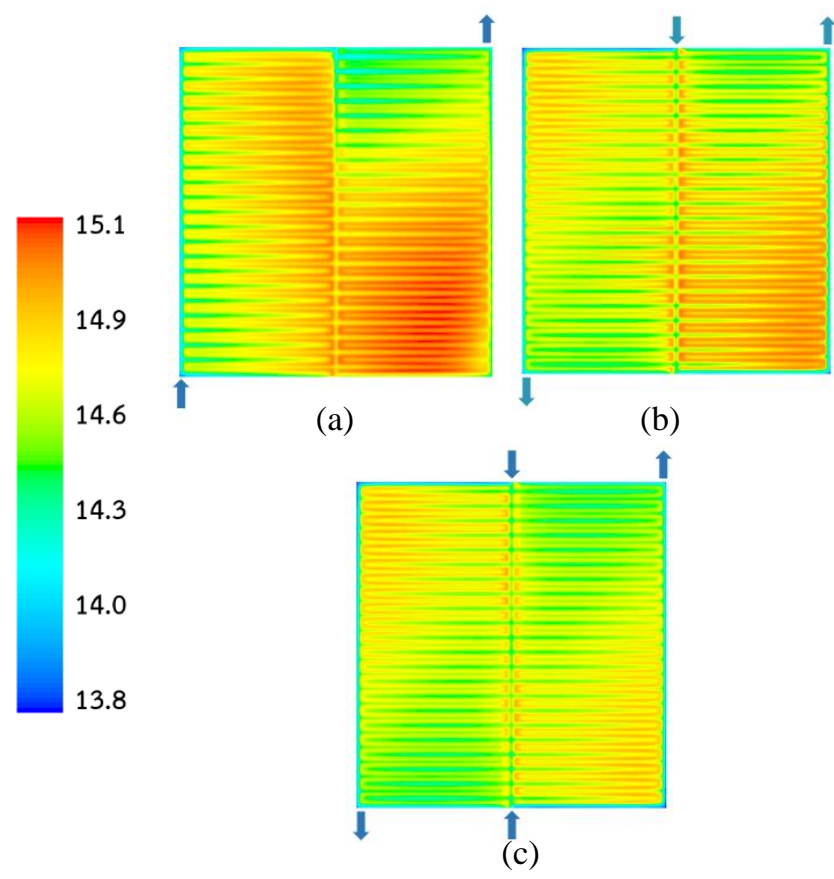

Figure 4. Water content distribution on the interface between the membrane and the cathode catalyst layers of (a) 1-IO HSI (b) 1I-2O HSI (c) 2-IO HSI flow fields 
N. Limjeerajarus \& T. Santiprasertkul: Improvement of a Hybrid SerpentineInterdigitated Flow Field by Adjusting Numbers of Inlet and Outlet of Gas Flow

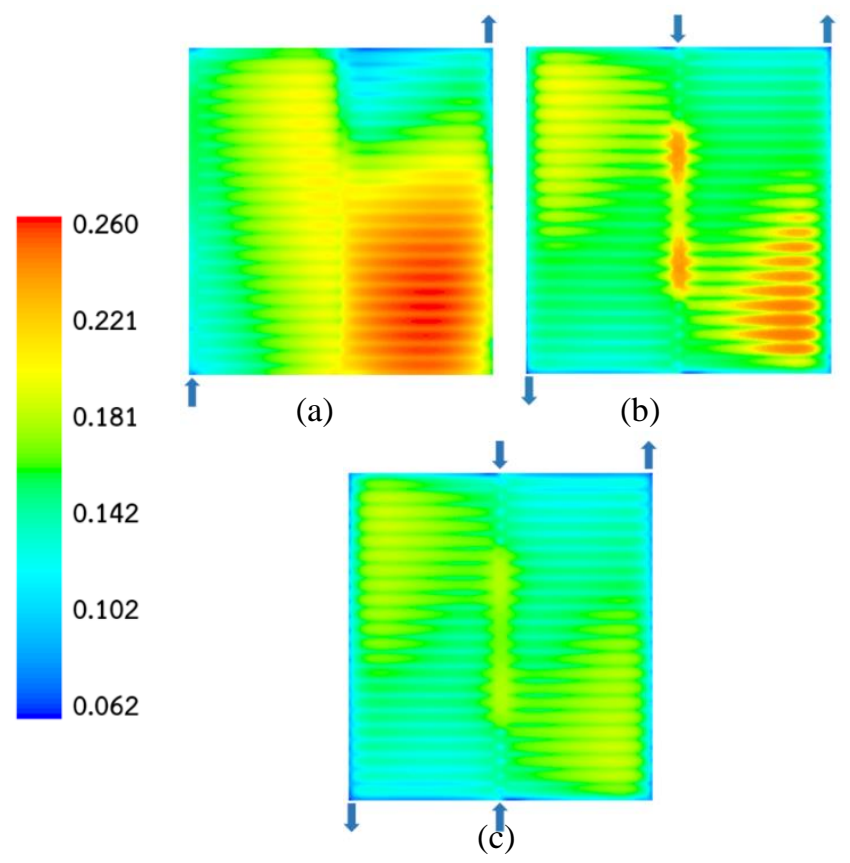

Figure 5. Water saturation distribution on the interface between the cathode catalyst and gas diffusion layers of (a) 1-IO HSI (b) 1I-2O HSI (c) 2-IO HSI flow fields

Owning to better water management, the less water flooding could be achieved in the 2IO HIS configuration, especially at the bottom-right corner of the cell. As a result, the reactant $\mathrm{O}_{2}$ could reach any part of the cell more efficiently, which coincided with the result of oxygen mass fraction distribution shown in Fig.3, resulting in the best IV performance.

\section{Conclusion}

The modification of gas inlets/outlets of HIS flow field configuration had been numerically studied, aiming to solve the problem of low oxygen mass fraction area, and to improve cell performance. Three cases of 1-IO HIS, 1I-2O HIS and 2-IO HIS were proposed and investigated using CFD simulation via ANSYS FLUENT software. The simulation results suggested that the 2-IO-HSI configuration outperformed the other two configurations in the viewpoints of the cell performance, the oxygen mass fraction distribution and also the water management due to its shortest length of gas flow channels. Furthermore, the 2-IO HSI configuration offered much more uniform distributions of oxygen and water, which could lead to longer cell life time. Therefore, the 2-IO HSI configuration could be a promising flow field design for a practical scale 
$10^{\mathrm{TH}}$ International Conference on Sustainable Energy and Environmental Protection (June $27^{\mathrm{TH}}-30^{\mathrm{TH}}, 2017$, Bled, SLovenia), Hydrogen ANd Fuel Cells

N. Limjeerajarus \& T. Santiprasertkul: Improvement of a Hybrid SerpentineInterdigitated Flow Field by Adjusting Numbers of Inlet and Outlet of Gas Flow Channels

like $50 \mathrm{~cm}^{2}$. However, to confirm its performance and merits, this flow field still needs the experimental examination, which is ongoing in our research group.

\section{Acknowledgements}

The authors would like to express their gratitude to Thai-Nichi Institute of Technology for providing a financial support for this research (Grant ID: 1610/A009).

\section{References}

[1] A. Arvay, J. French, J. C. Wang, X. H. Peng and A. M. Kannan, "Nature inspired flow field designs for proton exchange membrane fuel cell," International of Hydrogen Energy, vol. 38(9), pp. 3717-3726, March. 2013.

[2] M. Esteban and D. Leary, "Current developments and future prospects of offshore wind and ocean energy," Applied Energy, vol. 90(1), pp. 128-136, Feb. 2012.

[3] A.P. Manso, F.F. Marzo, J. Barranco, X. Garikano and M. Mujika Garmendia, "Influence of geometric parameters of the flow fields on the performance of a PEM fuel cell. A review," International of Hydrogen Energy, vol. 37(20), pp. 15256-15287, Oct. 2012.

[4] P. Charoen-amornkitt, T. Santiprasertkul, P. Munprakobkij and N. Limjeerajarus "Numerical Study of a Polymer Electrolyte Fuel Cell with a Hybrid SerpentineInterdigitated Flow Field Design," presented at the 6th TSME International Conference on Mechanical Engineering, Hua-Hin, 2015.

[5] L. Seungjae, K. Taeyoung and P. Heekyung, "Comparison of multi-inlet and serpentine channel design on water production of PEMFCs," Chemical Engineering Science, vol. 66(8), pp. 1748-1758, Apr. 2011.

[6] HK. Versteeg and W. Malalasekera, An introduction to computational fluid dynamics: the finite volume method. 2nd ed. Pearson Education, Glasgow: Bell\&Bain Limited, 2007.

[7] N. Limjeerajarus and P. Charoen-amornkitt, "Effect of different flow field designs and number of channels on performance of a small PEFC," International Journal of Hydrogen Energy, vol. 40(22), pp. 7144-7158, Jun. 2015.

[8] N. Limjeerajarus, Y. Nishiyama, H. Ohashi, T. Ito and T. Yamaguchi "Modeling for PEFC MEAs based on reaction rate on Pt surface and microstructures of catalyst layers," Journal of chemical engineering of Japan, vol. 42(8), pp. 616-631, August. 2009.

[9] L. Xianguo and I. Sabir "Review of bipolar plates in PEM fuel cells: flow field designs," International Journal of Hydrogen Energy, vol. 30(4), pp. 359-371, Mar. 2005. 
$10^{\mathrm{TH}}$ INTERNATIONAL CONFERENCE ON Sustainable ENERgy AND ENVIRONMENTAL Protection (June $27^{\mathrm{TH}}-30^{\mathrm{TH}}$, 2017, Bled, Slovenia), Hydrogen ANd Fuel Cells

J. Krope, A.Ghani Olabi, D. Goričanec \& S. Božičnik

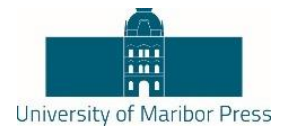

\title{
Concept of an Integrated Thermally Self-Sustained Methanol Steam Reformer - High-Temperature PEM Fuel Cell Stack Manportable System
}

\author{
ANDREJ Lotrič, MiHAEl SEKAVČNIK, ANDREJ POHAR, Blaž LiKOZAR \& STANKo \\ HOČEVAR
}

\begin{abstract}
A concept of an integrated system for small, manportable power units was investigated. The focus of this study is the direct thermal coupling of a methanol steam reformer (MSR) and a high-temperature proton exchange membrane fuel cell (HT PEMFC) stack. A recently developed low-temperature (LT) MSR catalyst $(\mathrm{CuZnGaOx})$ was synthesized and tested in a designed reforming reactor. The experimental data show that $200{ }^{\circ} \mathrm{C}$ the complete conversion of methanol is achievable with a hydrogen yield of $45 \mathrm{~cm}^{3}$ min $1 \mathrm{gCAT} 1$. The obtained LT MSR kinetic parameters and the measured characteristics of the two-cell HT PEMFC stack were used in the modelling of the integrated system. The simulations show that the integrated system, which also includes a vaporizer, can achieve a thermally self-sustained working point. The model predicts a power output of $8.5 \mathrm{~W}$, a methanol conversion of $98.5 \%$, and a gross electrical efficiency of $21.7 \%$ (higher heating value).
\end{abstract}

Keywords: • methanol steam reformer $\bullet$ logistic fuel processor $\bullet$ PEM fuel cell $\bullet$ thermal system integration $\bullet$ modelling and optimization •

CORRESPONDENCE ADDRESS: Andrej Lotrič, Ph.D. Student, University of Ljubljana, Faculty of Mechanical Engineering, Aškerčeva 6,1000 Ljubljana, Slovenia, e-mail: andrej.lotric@fs.unilj.si. Mihael Sekavčnik, Ph.D., Professor, University of Ljubljana, Faculty of Mechanical Engineering, Aškerčeva 6, 1000 Ljubljana, Slovenia, e-mail: mihael.sekavcnik@fs.uni-lj.si. Andrej Pohar, Ph.D., Assistant Professor, National Institute of Chemistry Slovenia, Hajdrihova 19, 1000 Ljubljana, Slovenia, e-mail: andrej.pohar@ki.si. Blaž Likozar, Ph.D., Assistant Professor, National Institute of Chemistry Slovenia, Hajdrihova 19, 1000 Ljubljana, Slovenia, email: blaz.likozar@ki.si. Stanko Hočevar, Ph.D., Emeritus Professor, National Institute of Chemistry Slovenia, Hajdrihova 19, 1000 Ljubljana, Slovenia, e-mail: stanko.hocevar@ki.si. 
$10^{\mathrm{TH}}$ INTERNATIONAL CONFERENCE ON SUSTAINABLE ENERGy AND ENVIRONMENTAL Protection (June $27^{\mathrm{TH}}-30^{\mathrm{TH}}, 2017$, Bled, Slovenia), Hydrogen and Fuel Cells A. Lotrič, M. Sekavčnik, A. Pohar, B. Likozar \& S. Hočevar: Concept of an Integrated Thermally Self-Sustained Methanol Steam Reformer - High-Temperature PEM Fuel Cell Stack Manportable System

Introduction

Proton exchange membrane fuel cell (PEMFC) technology is slowly entering the market for small, manwearable and manportable power applications. This is primarily because they can attain a higher specific energy than Li-ion batteries, which results in lower weight and longer autonomy of the power unit [1]. An attractive option to further increase the energy density of PEMFC portable applications is to use methanol instead of hydrogen as the fuel. This is not only because methanol has a higher volumetric energy density, but also because of methanol's properties with respect to storage and transportation, which are much better than those of pure hydrogen.

Due to the highest attainable hydrogen concentration in the reformate stream, endothermic methanol steam reforming is more attractive than auto-thermal steam reforming or partial oxidation of methanol. Since a methanol steam reformer (MSR) is a heat consuming device it would be very convenient to form a heat integrated system where the otherwise redundant waste heat produced by a HT PEMFC stack could be directly transferred to a MSR and thus effectively put to use.

Until now this was not practicable because there was a temperature gap between the operating temperatures of the PEMFC stack and the MSR. Conventional hightemperature (HT) PEMFC based on polybenzimidazole (PBI) polymer doped with phosphoric acid $\left(\mathrm{H}_{3} \mathrm{PO}_{4}\right)$ operate best within the temperature interval $160-180{ }^{\circ} \mathrm{C}$ and up to $200{ }^{\circ} \mathrm{C}$, but at this temperature the degradation processes become more rapid. The use of conventional catalysts enables the MSR to attain practically full conversion at relatively low temperatures between $250-300{ }^{\circ} \mathrm{C}$. Unfortunately, these temperatures exceed the operation temperatures of the conventional HT PEMFC. However, other unconventional or novel HT PEMFCs capable of operating above $250{ }^{\circ} \mathrm{C}$ have been developed [2,3] or are still under development [4] but they are not market mature yet. Their successful commercialization would allow direct thermal coupling with the MSR using conventional reforming catalysts.

On the other hand, a low-temperature (LT) MSR catalyst was recently discovered that shows great potential to achieve complete conversion of methanol with a very low $\mathrm{CO}$ content at temperatures below $200{ }^{\circ} \mathrm{C}[5,6]$. Low temperatures disfavour the reverse water-gas shift reaction (rWGS) which according to [7] is the main cause of $\mathrm{CO}$ formation. The developed LT MSR catalyst enables direct thermal coupling of the HT PEMFC stack and the LT MSR into an integrated thermally self-sustained system.

Directly utilizing the heat produced by the HT PEMFC stack in the reformed methanol fuel cell (RMFC) system was first shown in [8] although at the temperature of $200{ }^{\circ} \mathrm{C}$ close to $100 \%$ methanol conversion could only be achieved at a very low hydrogen yield around $6.7 \mathrm{~cm}^{3} \mathrm{~min}^{-1} \mathrm{~g}_{\mathrm{CAT}}{ }^{-1}$. Similar but a more advanced approach was taken in study [9] where a two stage MSR was used. The first stage was in direct thermal contact with the HT PEMFC stack and the second stage was heated with the catalytic combustor using 
$10^{\mathrm{TH}}$ INTERNATIONAL CONFERENCE ON SUSTAINABLE ENERGY AND ENVIRONMENTAL Protection (June $27^{\mathrm{TH}}-30^{\mathrm{TH}}, 2017$, Bled, SLovenia), EnERGy Storage

A. Lotrič, M. Sekavčnik, A. Pohar, B. Likozar \& S. Hočevar: Concept of an Integrated

Thermally Self-Sustained Methanol Steam Reformer - High-Temperature PEM Fuel

Cell Stack Manportable System

anode off-gas as the fuel. Most recently published was a numerical and experimental study [10] of the integrated system constructed from an internally RMFC stack, where the methanol was reformed by a catalyst incorporated into the anode compartment of the HT PEMFC.

The goal is to characterize the newly developed LT MSR catalyst and a two-cell HT PEMFC stack. The obtained kinetic data will be used to predict the operational characteristics of the LT MSR that will be directly thermally coupled with the stack of HT PEMFCs into the integrated system. The main objective is to predict or identify a working point where the system becomes thermally self-sustained (e.g. when all the heat produced is in balance with the heat consumed and lost to the environment).

\section{Experimental Setup}

\subsection{Methanol steam reformer}

A pH-controlled co-precipitation method was used to synthesize the highly active $\mathrm{CuZnGaOx}$ catalyst. $6.03 \mathrm{~g}$ of the synthesized catalyst was inserted into the reformer. The reformer is made from three separate stainless-steel plates welded together; the design can be seen on Figure 1. The inlet (1) and outlet (2) channels go through the upper plate. In the middle plate a reaction chamber was cut out (3), which was filled with the catalyst through the service hole (4) in the bottom plate. Two inserts with guide holes (5), for aligning the reformer to the fuel cell, were placed in the positioning holes (6) and welded onto the upper and bottom plates. A wire mesh (7) was inserted into the slots (8) at the inlet and outlet sides of the reaction chamber in order to entrap the catalyst. The planar shape of the reformer is required for the integration with the fuel cell stack. 
$10^{\mathrm{TH}}$ International Conference on Sustainable Energy and Environmental Protection (June $27^{\mathrm{TH}}-30^{\mathrm{TH}}, 2017$, Bled, Slovenia), Hydrogen and Fuel Cells A. Lotrič, M. Sekavčnik, A. Pohar, B. Likozar \& S. Hočevar: Concept of an Integrated Thermally Self-Sustained Methanol Steam Reformer - High-Temperature PEM Fuel Cell Stack Manportable System

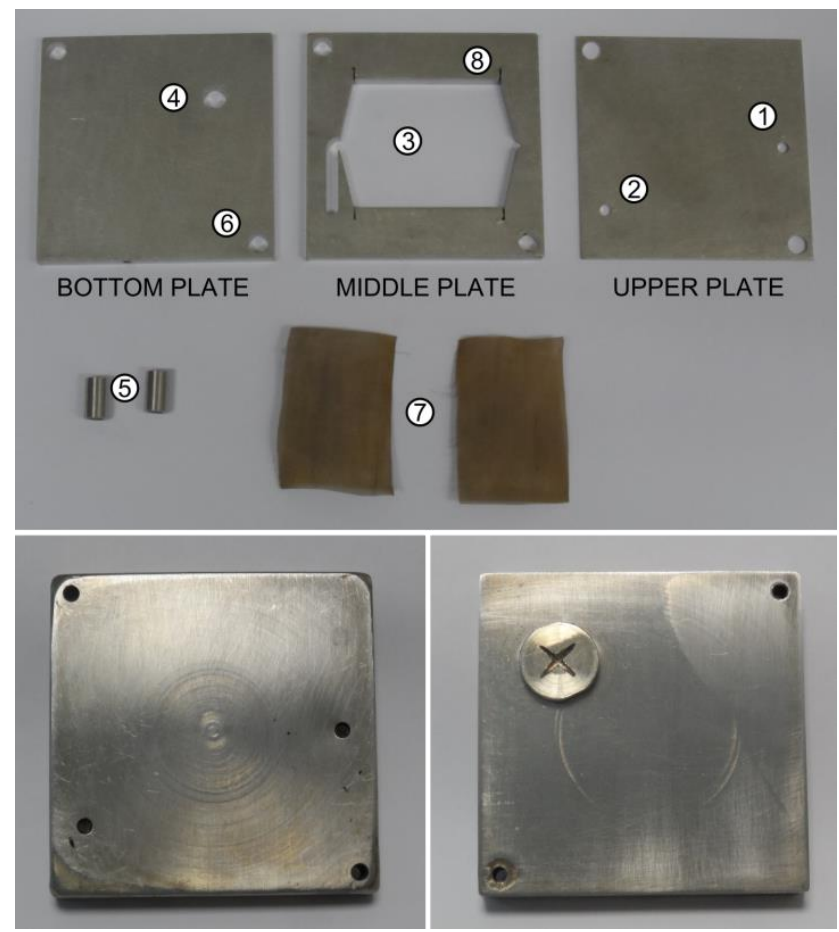

Figure 1. Premanufactured LT MSR parts (top), upper side (bottom left) and bottom side (bottom right) of the constructed LT MSR

The packed bed reactor was modelled considering the processes of convection, axial dispersion and chemical reaction. Mass transfer to the surface of the catalyst particles was neglected due to the small size of the catalyst particles. The viscosity and density of the gaseous mixture, as well as the diffusion coefficients, were calculated through appropriate equations of state [11].

Based on the mechanism proposed in [7] the following power-law empirical correlation was used for the description of the reaction kinetics of the LT MSR reaction:

$$
r_{M S R}=A_{M S R} e^{-\frac{E a_{M S R}}{R T}} P_{M e O H}^{a} P_{H_{2} O}^{b} \rho_{c a t}
$$

where $r_{\mathrm{MSR}}$ is the rate of reaction, $A_{\mathrm{MSR}}$ is the pre-exponential factor, $E a_{\mathrm{MSR}}$ is the activation energy, $R$ is the ideal gas constant, $T$ is the temperature and $P_{\mathrm{i}}$ is the partial pressure. The empirical kinetic parameters obtained through the regression analysis are presented in Table 1. 
$10^{\mathrm{TH}}$ INTERNATIONAL CONFERENCE ON SUSTAINABLE ENERGY AND ENVIRONMENTAL Protection (June $27^{\mathrm{TH}}-30^{\mathrm{TH}}, 2017$, Bled, SLovenia), EnERGy Storage

A. Lotrič, M. Sekavčnik, A. Pohar, B. Likozar \& S. Hočevar: Concept of an Integrated

Thermally Self-Sustained Methanol Steam Reformer - High-Temperature PEM Fuel

Cell Stack Manportable System

Table 1. The kinetic parameters of the LT MSR reaction on the $\mathrm{CuZnGaOx}$ catalyst

\begin{tabular}{|c|c|c|c|}
\hline $\begin{array}{c}A_{M S R} \\
\left(\mathrm{~mol} \mathrm{bar}^{(-\mathrm{a}-\mathrm{b})} \mathrm{s}^{-1} \mathrm{~kg}_{\mathrm{cat}^{-1}}\right)\end{array}$ & $\begin{array}{c}E a_{M S R} \\
\left(\mathrm{~J} \mathrm{~mol}^{-1}\right)\end{array}$ & $\begin{array}{c}a \\
/\end{array}$ & $\begin{array}{c}b \\
/\end{array}$ \\
\hline $1.012 \times 10^{7}$ & 74,000 & 0.43 & 0.39 \\
\hline
\end{tabular}

The activity of the LT MSR was analysed by examining the methanol conversion as a function of hydrogen yield. The experimental data show that increasing the temperature from $180^{\circ} \mathrm{C}$ to $200{ }^{\circ} \mathrm{C}$ has a very beneficial effect on the hydrogen yield allowing $99.1 \%$ conversion at $62 \mathrm{~cm}^{3} \mathrm{~min}^{-1} \mathrm{~g}_{\mathrm{CAT}}{ }^{-1}$ (this corresponds to the flow rate of $0.2 \mathrm{ml} \mathrm{min}^{-1}$ ). It is shown in Figure 2 that the kinetic model, corroborated by experimental data, predicts that at $200{ }^{\circ} \mathrm{C}$ complete conversion of methanol is possible at hydrogen yields of up to $45 \mathrm{~cm}^{3} \mathrm{~min}^{-1} \mathrm{~g}_{\mathrm{CAT}}{ }^{-1}$. This is a threefold increase compared to a study [12] where complete conversion was possible at hydrogen yields of up to $15 \mathrm{~cm}^{3} \mathrm{~min}^{-1} \mathrm{~g}_{\mathrm{CAT}}{ }^{-1}$ using one of the finest commercially available catalysts HiFuel R120.

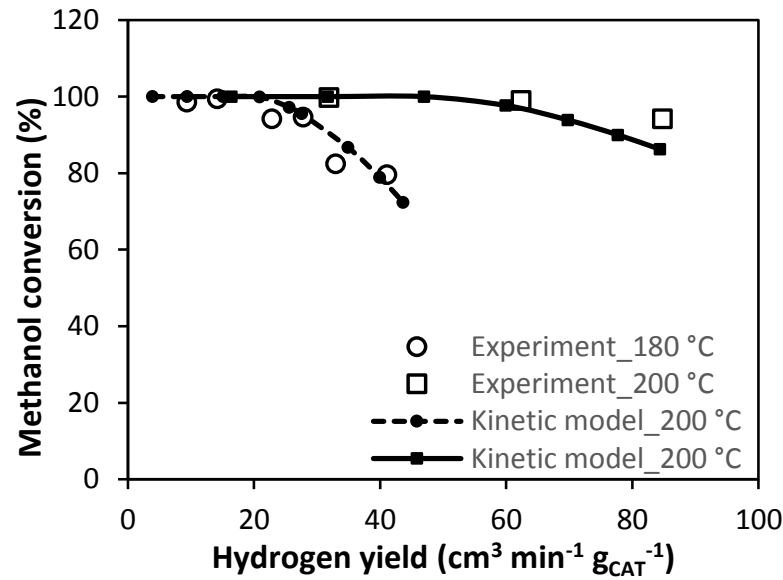

Figure 2. Methanol conversion as a function of hydrogen yield at SMR $=1.3$

\subsection{Fuel cell stack}

The stack consists of two HT PEMFCs each with an active area of $12.9 \mathrm{~cm}^{2}$. The membrane electrode assemblies were custom designed and purchased from Danish Power Systems (DPS). Graphite composite bipolar plates $(60 \mathrm{~mm} \times 60 \mathrm{~mm} \times 4 \mathrm{~mm}$ in width, length and thickness) were custom designed and purchased from Bac2. Custom design was also needed for Viton gaskets which were developed together with company Klander d.o.o. The stack was sandwiched between two layers of insulation (Microtherm ${ }^{\circledR}$ Board) and then compressed from both sides with aluminium alloy end plates $(78 \mathrm{~mm} \times 78 \mathrm{~mm}$ x $20 \mathrm{~mm}$ in width, length and thickness). The upper plate was also fitted with connectors for inlet and outlet gases. The experimental test system and the scheme of the experimental setup are shown in Figure 3. 
$10^{\mathrm{TH}}$ International Conference on Sustainable Energy and Environmental Protection (June $27^{\mathrm{TH}}-30^{\mathrm{TH}}, 2017$, Bled, Slovenia), Hydrogen and Fuel Cells A. Lotrič, M. Sekavčnik, A. Pohar, B. Likozar \& S. Hočevar: Concept of an Integrated Thermally Self-Sustained Methanol Steam Reformer - High-Temperature PEM Fuel Cell Stack Manportable System

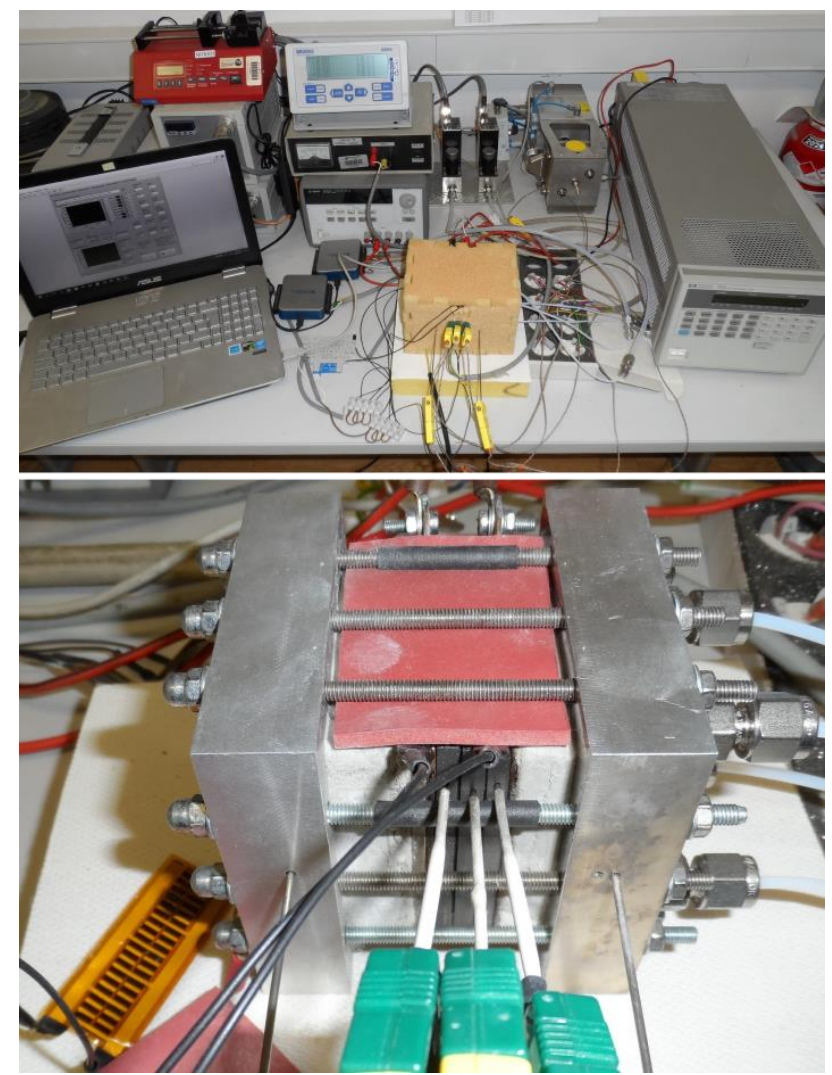

Figure 3. Experimental set-up for the HT PEMFC stack (top) and the HT PEMFC stack without insulation (bottom)

During the measurements the voltage differences between the first and the second HT PEMFC were fairly small through all the current density range, being $-7 \mathrm{mV}$ at $0.1 \mathrm{~A} \mathrm{~cm}^{-2}$ and $9 \mathrm{mV}$ at $0.8 \mathrm{~A} \mathrm{~cm}^{-2}$. That is why dividing the measured HT PEMFC stack voltages by the number of cells to get a single cell polarization curve is a reasonable approximation. The power density characteristics shown in Figure 4 were used in the modelling of the integrated system. 
A. Lotrič, M. Sekavčnik, A. Pohar, B. Likozar \& S. Hočevar: Concept of an Integrated

Thermally Self-Sustained Methanol Steam Reformer - High-Temperature PEM Fuel

Cell Stack Manportable System

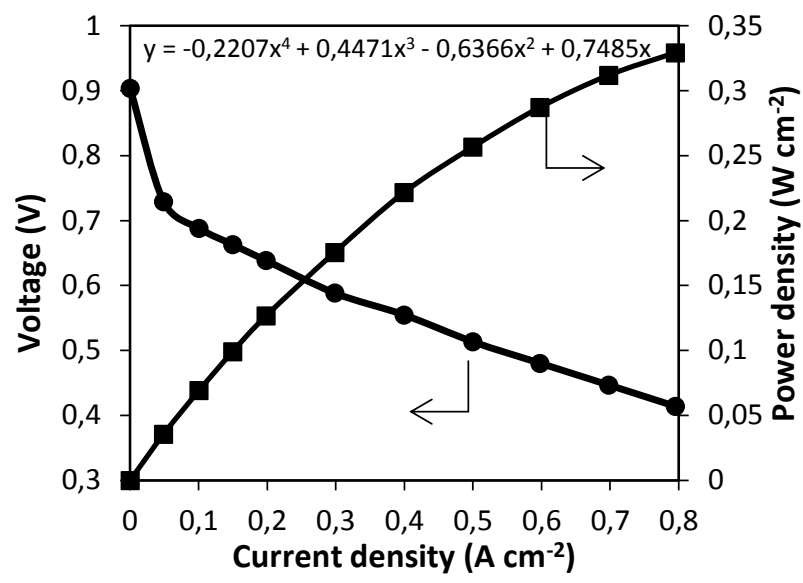

Figure 4. Characteristics of the single HT PEMFC at T $=180{ }^{\circ} \mathrm{C}, \lambda_{H 2}=1.5, \lambda_{A I R}=2.5$ used in the modelling of the integrated system

\section{$3 \quad$ Simulation Approach}

Basic design of the prototype system (shown on Figure 5) has been developed in 3D modelling software SolidWorks. The model is used to visualize the prototype system while it also allows detecting construction issues prior to making changes or adaptations.

The simulation approach (using Aspen Plus and Comsol Multiphysics interactive modelling), explained in scientific paper [13], was used to obtain geometrical and operational characteristics of the conceived integrated system.

\section{$4 \quad$ Numerical Modelling}

The integrated system was modelled as shown in Figure 6. The thermally self-sustained working point of the integrated system is reached at $0.8 \mathrm{~A} \mathrm{~cm}^{-2}$ where the HT PEMFC stack produces $8.5 \mathrm{~W}$ of electricity and $17.3 \mathrm{~W}$ of heat.

In Comsol Multiphysics the calculated heat flows of the integrated system are combined 

Protection (June $27^{\mathrm{TH}}-30^{\mathrm{TH}}, 2017$, Bled, Slovenia), Hydrogen and Fuel Cells A. Lotrič, M. Sekavčnik, A. Pohar, B. Likozar \& S. Hočevar: Concept of an Integrated Thermally Self-Sustained Methanol Steam Reformer - High-Temperature PEM Fuel Cell Stack Manportable System

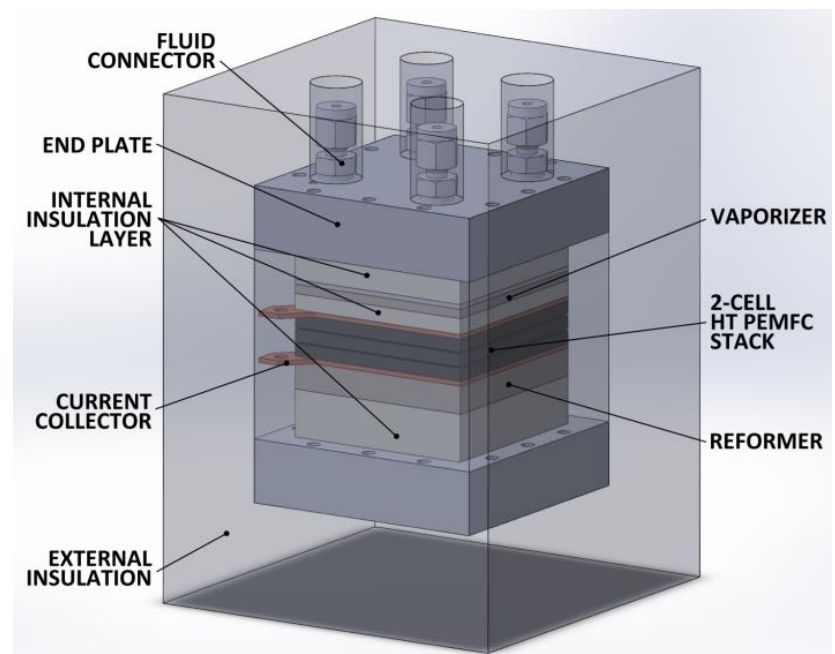

Figure 5. Conceptual design of the integrated thermally self-sustained system; external insulation is transparent

with the system design (Figure 5), which takes into account the physical properties of the materials, to obtain the approximate temperature profile (see Figure 7). Also, heat losses of the system are evaluated which are around $4.8 \mathrm{~W}$.

To produce a sufficient amount of hydrogen, $0.2 \mathrm{~mL} \mathrm{~min}^{-1}$ of liquid methanol-water mixture with $\mathrm{SMR}=1.3$ is needed. At this volumetric flow $98.5 \%$ conversion of methanol is achieved by the LT MSR. The incoming feed flow corresponds to $38.9 \mathrm{~W}$ of heat input based on higher heating value (HHV). Anode and cathode stream exiting the integrated system still carry a substantial part of heat, mostly because excess hydrogen and unconverted methanol are unutilized. Model unit BURNER calculates that around $25.6 \mathrm{~W}$ is rejected to the surroundings when the combustible components are burned and the stream is cooled down to $25^{\circ} \mathrm{C}$. The system achieved a gross electrical efficiency of $21.7 \%$. 
$10^{\mathrm{TH}}$ INTERNATIONAL CONFERENCE ON SUSTAINABLE ENERGY AND ENVIRONMENTAL

Protection (June $27^{\mathrm{TH}}-30^{\mathrm{TH}}, 2017$, Bled, Slovenia), Energy Storage

A. Lotrič, M. Sekavčnik, A. Pohar, B. Likozar \& S. Hočevar: Concept of an Integrated

Thermally Self-Sustained Methanol Steam Reformer - High-Temperature PEM Fuel

Cell Stack Manportable System

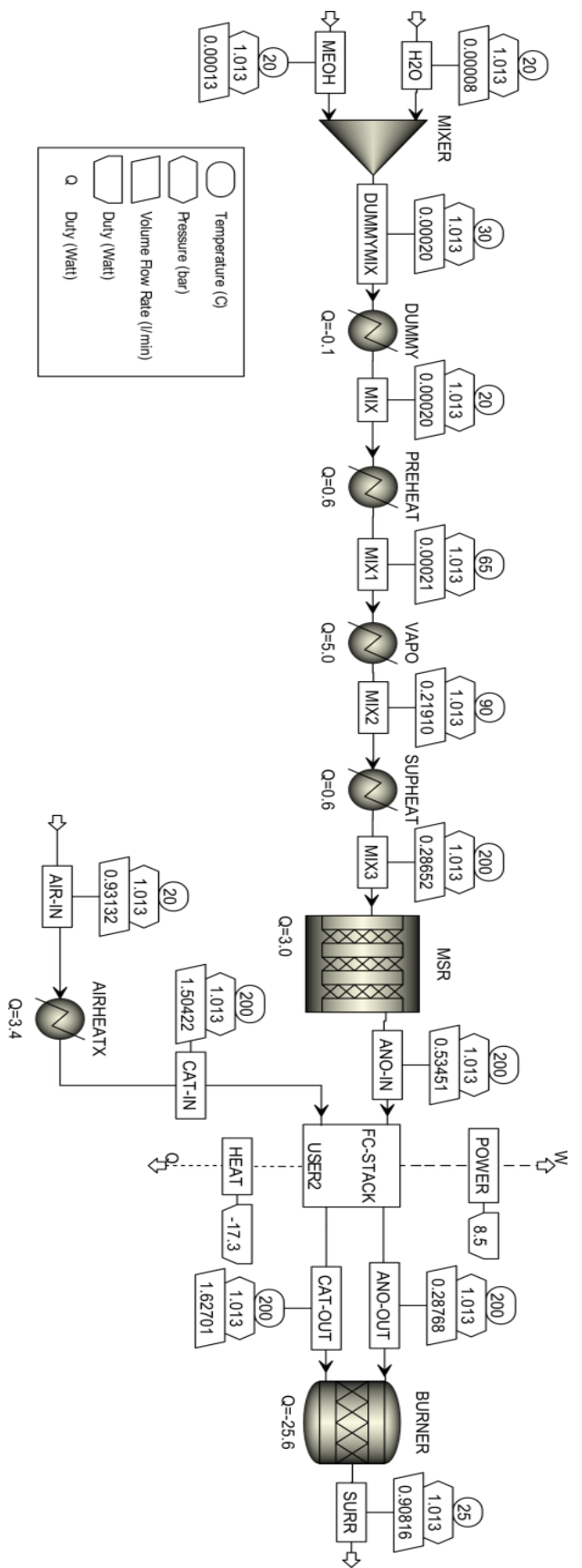

Figure 6. Flowchart of the modelled integrated system 
$10^{\mathrm{TH}}$ International Conference on Sustainable Energy and Environmental Protection (June $27^{\mathrm{TH}}-30^{\mathrm{TH}}, 2017$, Bled, Slovenia), Hydrogen and Fuel Cells A. Lotrič, M. Sekavčnik, A. Pohar, B. Likozar \& S. Hočevar: Concept of an Integrated Thermally Self-Sustained Methanol Steam Reformer - High-Temperature PEM Fuel Cell Stack Manportable System

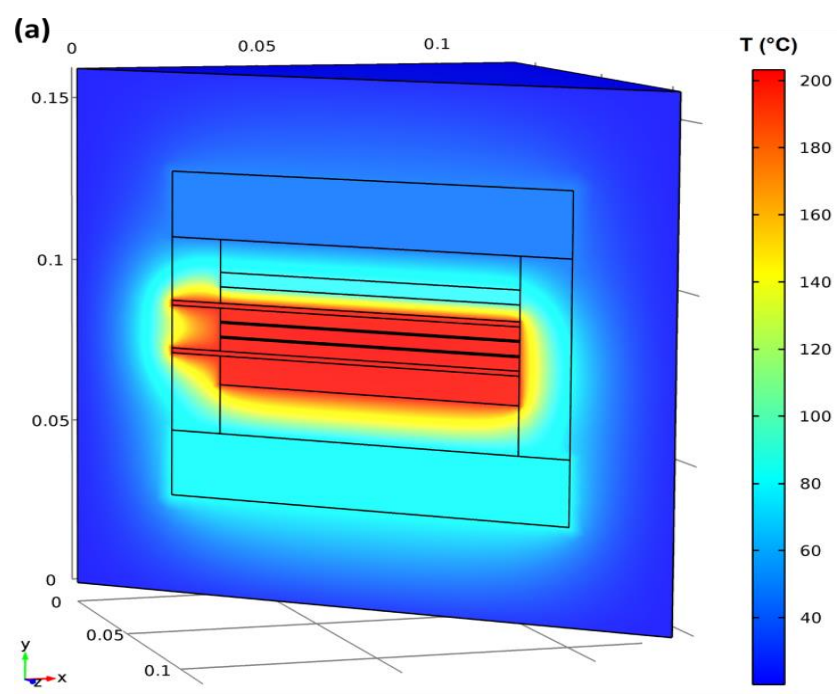

(b)

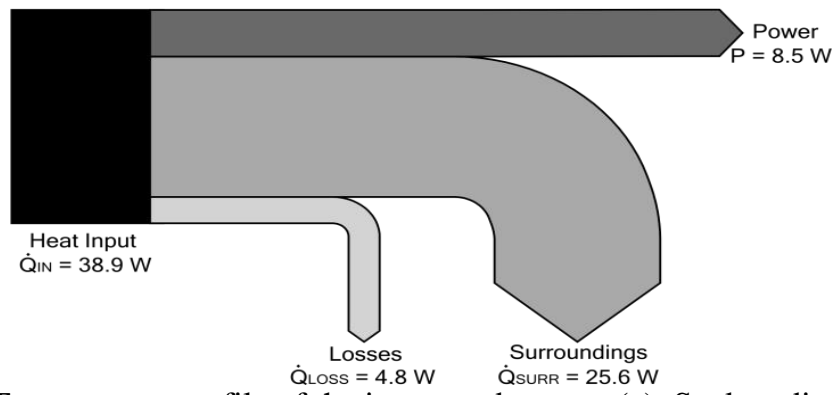

Figure 7. Temperature profile of the integrated system (a), Sankey diagram of the energy flows (b)

Measurements at excess ratios lower than those suggested by the supplier were also performed, since using a smaller hydrogen excess ratio is directly reflected in improved efficiency of the system. It can be seen in Figure 8 that reducing the hydrogen excess ratio significantly aggravated the characteristics of the second HT PEMFC (labelled as FC2). This was attributed to the fact that distribution of the gases between the two HT PEMFCs in the stack was uneven. By using the laser profilometer it was confirmed that the depth of the flow field channels is not the same on both bipolar plates. As a consequence, the plate with deeper channels has a higher volumetric flow rate. That is why a new set of bipolar plates will be manufactured where special attention will be given to the equality of channel depths. 
$10^{\mathrm{TH}}$ INTERNATIONAL CONFERENCE ON SUSTAINABLE ENERGY AND ENVIRONMENTAL Protection (June $27^{\mathrm{TH}}-30^{\mathrm{TH}}, 2017$, Bled, SLovenia), EnERGy Storage

A. Lotrič, M. Sekavčnik, A. Pohar, B. Likozar \& S. Hočevar: Concept of an Integrated

Thermally Self-Sustained Methanol Steam Reformer - High-Temperature PEM Fuel

Cell Stack Manportable System

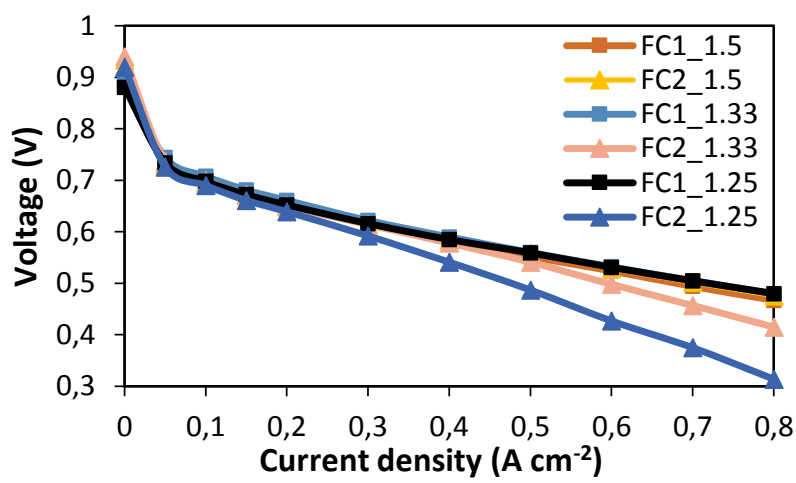

Figure 8. Voltage characteristics of the two HT PEMFCs at constant oxygen excess ratio $\lambda_{\mathrm{O} 2}=2.5$ and various hydrogen excess ratios (ranging from 1.5 to 1.25 )

At $185^{\circ} \mathrm{C}$ the HT PEMFC stack reached the thermally self-sustained working point at a relatively high current density of $0.76 \mathrm{~A} \mathrm{~cm}^{-2}$, which was attributed to poor insulation of the system.

The external insulation of the HT PEMFC stack was made from soft and quite delicate polyimide foam. However, the mechanical and hence thermal properties of the insulation visibly deteriorated during the use in this and previous experiments. For the integrated system, a new, mechanically more resilient aerogel insulation, which also has a lower thermal conductivity, will be used to further reduce the thermal losses.

Also, internal insulation layers were made from a compressed powder blend of filamentreinforced silica. This material is rather soft and compresses easily at pressures above $0.5 \mathrm{MPa}$. To prevent any creep during the fastening of the bolts the material was precompressed. It was later discovered that the applied pressure was too high, which led to poorer insulating properties because the material was over-compressed.

\section{Acknowledgements}

The experimental work with HT PEMFC stack was carried out at the facilities of SME Mebius d.o.o., while the experimental work with the LT MSR was performed at the National Institute of Chemistry.

The research was supported by NATO in the framework of the Science for Peace and Security (SPS) Programme under agreement EAP.SFPP 984738, Slovenian Ministry of Defence under agreement 4300-434/2010-1, and Centre of Excellence for Low-Carbon Technologies (CO NOT).

The provision of financial support, for the conduct of the research and the preparation of the article, by the Slovenian Research Agency (ARRS) (Program P2-0152) and the World Federation of Scientists (WFS) is also gratefully acknowledged. 
$10^{\mathrm{TH}}$ InTERnAtional CONFERENCE ON Sustainable EnERgy AND ENVIRONMENTAL Protection (June $27^{\mathrm{TH}}-30^{\mathrm{TH}}, 2017$, Bled, Slovenia), Hydrogen and Fuel Cells A. Lotrič, M. Sekavčnik, A. Pohar, B. Likozar \& S. Hočevar: Concept of an Integrated Thermally Self-Sustained Methanol Steam Reformer - High-Temperature PEM Fuel Cell Stack Manportable System

Special thanks go to the company Klander d.o.o. for collaboration in the development of the Viton gaskets and also to Promat d.o.o. for providing a sample Microtherm ${ }^{\circledR}$ Board insulation.

\section{References}

[1] "Fuel Cells and Other Emerging Manportable Power Technologies for the NATO Warfighter - Part I: Power Sources for Manportable/Manwearable Applications," NATOSTO-TR-SET-173-Part-I, 10/31/2014 2014.

[2] C. R. I. Chisholm et al., "From Laboratory Breakthrough to Technological Realization: The Development Path for Solid Acid Fuel Cells," Interface, Article vol. 18, no. 3, pp. 53-59, Fall2009 2009.

[3] Q. Geletu, K. Ryuji, T. Atsushi, S. Takashi, and S. T. Oyama, "CsH2PO4/Polyvinylidene Fluoride Composite Electrolytes for Intermediate Temperature Fuel Cells," Journal of the Electrochemical Society, vol. 161, no. 4, p. F451, 04// 2014.

[4] S. Hočevar and A. Kržan, "Polyoxometalate Salts, Proton Exchange Membranes and Precursors, Membrane-Electrode Assemblies, Fuel Cells and Methods," Patent application PCT/EP2014/070697.

[5] K. M. K. Yu et al., "Non-syngas direct steam reforming of methanol to hydrogen and carbon dioxide at low temperature," (in English), Nature Communications, Article vol. 3, 01 / 01 / 2012.

[6] W. Tong, K. Cheung, A. West, K.-M. Yu, and S. C. E. Tsang, "Direct methanol steam reforming to hydrogen over $\mathrm{CuZnGaOx}$ catalysts without $\mathrm{CO}$ post-treatment: mechanistic considerations," Physical Chemistry Chemical Physics, 10.1039/C3CP51073E vol. 15, no. 19, pp. 7240-7248, 2013.

[7] H. Purnama, T. Ressler, R. E. Jentoft, H. Soerijanto, R. Schlögl, and R. Schomäcker, "CO formation/selectivity for steam reforming of methanol with a commercial $\mathrm{CuO} / \mathrm{ZnO} / \mathrm{Al} 2 \mathrm{O} 3$ catalyst," Applied Catalysis A: General, vol. 259, no. 1, pp. 83-94, 3/8/ 2004.

[8] C. Pan et al., "Integration of high temperature PEM fuel cells with a methanol reformer," Journal of Power Sources, vol. 145, no. 2, pp. 392-398, 8/18/ 2005.

[9] F. Weng, C.-K. Cheng, and K.-C. Chen, "Hydrogen production of two-stage temperature steam reformer integrated with PBI membrane fuel cells to optimize thermal management," International Journal of Hydrogen Energy, vol. 38, no. 14, pp. 6059-6064, 5/10/ 2013.

[10] G. Avgouropoulos et al., "Performance evaluation of a proof-of-concept $70 \mathrm{~W}$ internal reforming methanol fuel cell system," Journal of Power Sources, vol. 307, pp. 875-882, 3/1/ 2016 .

[11] A. Pohar, D. Belavič, G. Dolanc, and S. Hočevar, "Modeling of methanol decomposition on $\mathrm{Pt} / \mathrm{CeO} 2 / \mathrm{ZrO} 2$ catalyst in a packed bed microreactor," Journal of Power Sources, vol. 256, pp. 80-87, 6/15/2014.

[12] G. Avgouropoulos, A. Paxinou, and S. Neophytides, "In situ hydrogen utilization in an internal reforming methanol fuel cell," International Journal of Hydrogen Energy, vol. 39, no. 31, pp. 18103-18108, 10/22/ 2014.

[13] A. Lotrič, M. Sekavčnik, and S. Hočevar, "Effectiveness of heat-integrated methanol steam reformer and polymer electrolyte membrane fuel cell stack systems for portable applications," Journal of Power Sources, vol. 270, no. 0, pp. 166-182, 12/15/ 2014. 
$10^{\mathrm{TH}}$ INTERNATIONAL CONFERENCE ON Sustainable ENERgy AND EnVironmental Protection (June $27^{\mathrm{TH}}-30^{\mathrm{TH}}$, 2017, BLed, Slovenia), Hydrogen ANd Fuel Cells

J. Krope, A.Ghani Olabi, D. Goričanec \& S. Božičnik

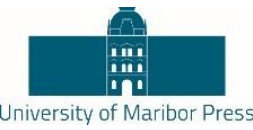

\title{
Transport Properties of Ca-Doped $\mathrm{Ln}_{2} \mathrm{NiO}_{4}$
}

\author{
Vladislav A. Sadykov, Elena Yu. Pikalova, Alexander A. Kolchugin, Nikita F. Eremeev, \\ Nina M. Bogdanovich, Azat F. Khasanov, Pavel I. Skriabin, Alexey V. Krasnov, \\ Ekaterina M. Sadovskaya, Alexander N. Shmakov, Zakhar S. Vinokurov, ArCady V. \\ ISHCHENKo, SERGEY M. PikAlov \& ElENA A. Filonova
}

\begin{abstract}
Ln}_{2} \mathrm{NiO}_{4}$ oxides with Ruddlesden-Popper structure having a high mixed ionic-electronic conductivity are important materials in developing oxygen separation membranes and cathodes of intermediate temperature solid oxide fuel cells. This work presents results of studies the structure, oxygen mobility and surface reactivity of Ca-doped $\mathrm{Ln}_{2} \mathrm{NiO}_{4}$. $\mathrm{Ln}_{2}$ xCaxNiO 4 oxides ( $\mathrm{Ln}=\mathrm{La}, \mathrm{Pr}, \mathrm{Nd} ; \mathrm{x}$ $=0,0.3$ ) prepared by the co-precipitation method were characterized by XRD and TEM. The oxygen mobility and surface reactivity were studied by the temperature programmed isotope exchange of oxygen with $\mathrm{C}_{18} \mathrm{O}_{2}$ and unit cell volume relaxation. Although doping results in enhanced electrical conductivity the overall oxygen mobility declines due to decreasing the content of highly mobile interstitial oxygen and hampering cooperative mechanism of oxygen migration. This results in the emergence of additional 1-2 channels of slow oxygen diffusion at a high dopant content related to transport in perovskite layers and via the interlayer positions near the dopant cation sites.
\end{abstract}

Keywords: • doped $\mathrm{Ln}_{2} \mathrm{NiO}_{4+\delta} \bullet$ layered structures $\bullet$ electrical conductivity - ionic diffusion $\bullet$ isotope exchange •

\footnotetext{
CORRESPONDENCE ADDRESS: Vladislav A. Sadykov, Prof. Dr., Head of laboratory, Boreskov Institute of Catalysis SB RAS, pr. Akad. Lavrentieva 5, Novosibirsk 630090, Russia, Novosibirsk State University, Pirogova str. 2, Novosibirsk 630090, Russia, e-mail sadykov@catalysis.ru. Elena Yu. Pikalova, Dr., Leading researcher, Institute of High Temperature Electrochemistry UB RAS, Akademicheskaya str. 20, Yekaterinburg 620137, Russia, Ural Federal University, Mira str. 19, Yekaterinburg 620002, Russia, e-mail: e.pikalova@list.ru. Alexander A. Kolchugin, PhD, Researcher, Institute of High Temperature Electrochemistry UB RAS, Akademicheskaya str. 20, Yekaterinburg 620137, Russia, Ural Federal University, Mira str. 19, Yekaterinburg 620002, Russia, e-mail: laba50@mail.ru. Nikita F. Eremeev, PhD, Researcher, Boreskov Institute of Catalysis SB RAS, pr. Akad. Lavrentieva 5, Novosibirsk 630090, Russia, e-mail: yeremeev21@gmail.com. Nina M. Bogdanovich, Researcher, Institute of High Temperature Electrochemistry UB RAS, Akademicheskaya str. 20, Yekaterinburg 620137, Russia, e-mail: bogdanovich@ihte.uran.ru. Azat F. Khasanov, Leading laboratory assistant, Ural Federal University, Mira str. 19, Yekaterinburg 620002, Russia, e-mail: azat@onlearning.ru. Pavel I. Skriabin, Junior researcher, Boreskov Institute of Catalysis SB RAS, pr. Akad. Lavrentieva 5, Novosibirsk 630090, Russia, e-mail: ivanovich1401@gmail.com. Alexey V. Krasnov, Engineer, Boreskov Institute of Catalysis SB RAS, pr. Akad. Lavrent ieva 5, Novosibirsk 630090, Russia, e-mail: leadenskyes@gmail.com. Ekaterina M. Sadovskaya, Dr., Senior researcher, Boreskov Institute of Catalysis SB RAS, pr. Akad. Lavrentieva 5, Novosibirsk 630090, Russia, Novosibirsk State University, Pirogova str. 2, Novosibirsk 630090, Russia, e-mail: sadovsk@catalysis.ru. Alexander N. Shmakov, Dr., Leading researcher, Boreskov Institute of Catalysis SB RAS, pr. Akad. Lavrentieva 5, Novosibirsk 630090, Russia, Novosibirsk State University, Pirogova str. 2, Novosibirsk 630090, Russia, Budker Institute of Nuclear Physics SB RAS, pr. Akad. Lavrentieva 11, Novosibirsk 630090, Russia, e-mail: shurka@catalysis.ru. Zakhar S. Vinokurov, Junior researcher, Boreskov Institute of Catalysis SB RAS, pr. Akad. Lavrentieva 5, Novosibirsk 630090, Russia, Budker Institute of Nuclear Physics SB RAS, pr. Akad. Lavrentieva 11, Novosibirsk 630090, Russia, e-mail: vinzux@mail.ru. Arcady V. Ishchenko, PhD, Researcher, Boreskov Institute of Catalysis SB RAS, pr. Akad. Lavrentieva 5, Novosibirsk 630090, Russia, Novosibirsk State University, Pirogova str. 2, Novosibirsk 630090, Russia, e-mail: arcady.ishchenko@gmail.com. Sergey M. Pikalov, Dr., Leading Engineer, Institute of Metallurgy, UB RAS, Amundsena str. 101, Yekaterinburg 620137, Russia, e-mail: s.pikalov@mail.ru. Elena A. Filonova, Assosiate Prof. Dr., Ural Federal University, Mira str. 19, Yekaterinburg 620002, Russia, e-mail: filonova1972@list.ru.
} 
$10^{\mathrm{TH}}$ InTERnAtional CONFERENCE ON Sustainable ENERGy AND ENVIRONMENTAL Protection (June $27^{\mathrm{TH}}-30^{\mathrm{TH}}, 2017$, Bled, Slovenia), Hydrogen and Fuel Cells V. A. Sadykov, E. Yu. Pikalova, A. A. Kolchugin, N. F. Eremeev, N. M. Bogdanovich, A. F. Khasanov, P. I. Skriabin, A. V. Krasnov, E. M. Sadovskaya, A. N. Shmakov, Z. S. Vinokurov, A. V. Ishchenko, S. M. Pikalov \& E. A. Filonova: Transport Properties of Ca-Doped $\mathrm{Ln}_{2} \mathrm{NiO}_{4}$

Materials with a high mixed ionic-electronic conductivity are required for developing functional layers of oxygen separation membranes and cathodes of intermediate temperature solid oxide fuel cells [1]. $\mathrm{Ln}_{2} \mathrm{NiO}_{4}$ oxides with layered Ruddlesden-Popper (R-P) structure having a high oxygen mobility are promising materials for such applications [2-6]. The high performance of single-button solid oxide fuel cells with cathodes based on $\operatorname{Pr}_{2} \mathrm{NiO}_{4+\delta}$ (power density up to $0.5 \mathrm{~W} / \mathrm{cm}^{2}$ at $700{ }^{\circ} \mathrm{C}$ ) was demonstrated $[7,8]$.

Ruddlesden - Popper structure consists of perovskite-like $\mathrm{LnNiO}_{3-\delta}$ layers having oxygen vacancies and rock salt-like $\mathrm{Ln}_{2} \mathrm{O}_{2+\delta}$ layers which can accumulate large amounts of highly mobile interstitial oxygen [9-11]. A high overall oxygen mobility in the surface and the bulk of the oxides (the oxygen tracer diffusion coefficient $D_{O} \sim 10^{-8} \mathrm{~cm}^{2} / \mathrm{s}$ at $700{ }^{\circ} \mathrm{C}$ ) is provided by a cooperative mechanism of diffusion via oxygen migration between interstitial and regular positions $[10,12]$.

Previously we demonstrated that doping $\mathrm{Ln}_{2} \mathrm{NiO}_{4}(\mathrm{Ln}=\mathrm{La}, \mathrm{Pr})$ by alkaline earth metal cations $(\mathrm{Ca}, \mathrm{Sr}, \mathrm{Ba}$ ) increased the total electric conductivity (up to $85 \mathrm{~S} / \mathrm{cm}$ ) [13]. However, the overall oxygen mobility and surface reactivity declined due to decreasing the content of highly mobile interstitial oxygen and hampering the cooperative mechanism of oxygen migration. This results in the formation of additional channels of slow oxygen diffusion which can involve up to $75 \%$ of overall bulk oxygen. Such effect reduces the electrochemical performance of these materials.

This work aims at studying the structure, oxygen mobility and surface reactivity of Cadoped $\mathrm{Ln}_{2} \mathrm{NiO}_{4}(\mathrm{Ln}=\mathrm{La}, \mathrm{Pr}, \mathrm{Nd})$.

\section{$2 \quad$ Materials and Methods}

$\mathrm{Ln}_{2-\mathrm{x}} \mathrm{Ca}_{\mathrm{x}} \mathrm{NiO}_{4+\delta}$ oxides $(\mathrm{Ln}=\mathrm{La}, \mathrm{Pr}, \mathrm{Nd} ; x=0,0.3$ ) were synthesized by the coprecipitation method. The final synthesis temperature was $1100-1250{ }^{\circ} \mathrm{C}$ as described elsewhere [14]. Ball-milling of powders was performed in a planetary mill SAND in isopropyl alcohol. After milling and drying, BET analysis (SORBI N.4.1 analyzer) was applied to estimate the specific surface area of powdered materials. Oxygen nonstoichiometry was determined by the iodometric method.

The X-ray powder diffraction (XRD) data were collected at room temperature using a Shimadzu XRD-7000 diffractometer (Japan) with $\mathrm{Cu} / \mathrm{K} \alpha$ radiation in the $2 \theta$ range $23-$ $83^{\circ}$ with a step of $0.02^{\circ}$ and fixed time of $5 \mathrm{~s}$ at each point. The profiles of diffraction patterns were analyzed with the Rietveld refinement program Fullprof. 
$10^{\mathrm{TH}}$ INTERNATIONAL CONFERENCE ON SUSTAINABLE ENERGY AND ENVIRONMENTAL Protection (June $27^{\mathrm{TH}}-30^{\mathrm{TH}}, 2017$, Bled, SLovenia), EnERgy Storage

V. A. Sadykov, E. Yu. Pikalova, A. A. Kolchugin, N. F. Eremeev, N. M. Bogdanovich,

A. F. Khasanov, P. I. Skriabin, A. V. Krasnov, E. M. Sadovskaya, A. N. Shmakov, Z. S.

Vinokurov, A. V. Ishchenko, S. M. Pikalov \& E. A. Filonova: Transport Properties of

Ca-Doped $\mathrm{Ln}_{2} \mathrm{NiO}_{4}$

High resolution transmission electron microscopy (HR TEM) images were obtained with a JEM-2010 (Jeol, Japan) instrument (lattice resolution $1.4 \AA$, acceleration voltage $\left.2 \cdot 10^{5} \mathrm{~V}\right)$

Conductivity of compact R-P samples (size $5 \times 5 \times 23 \mathrm{~mm}$ ) prepared by the uniaxial semi-dry pressing with polyvinyl butyral binder at $6 \mathrm{MPa}$ followed by sintering at $1450{ }^{\circ} \mathrm{C}$ for $5 \mathrm{~h}$ was measured by a $d c$ four-probe technique.

Oxygen mobility and surface reactivity of samples were studied by using the temperatureprogrammed isotope exchange (TPIE) with $\mathrm{C}^{18} \mathrm{O}_{2}$ in the flow reactor. The gas phase composition was analyzed by UGA-200 mass spectrometer (Stanford Research Systems, USA). Estimations of oxygen tracer diffusion coefficients $D_{O}$ and surface exchange constants $k_{e x}$ were carried out as described elsewhere [15-17].

Chemical diffusion coefficients $\left(D_{\text {chem }}\right)$ and chemical exchange constants $\left(k_{\text {chem }}\right)$ were calculated from the unit cell volume relaxation (UCVR) curves obtained using in situ SXRD data after an abrupt change of the oxygen partial pressure similarly to our previous research [9].

\section{$3 \quad$ Results and Discussion}

\subsection{Structural features}

According to the XRD data, all samples are single-phase materials. $\mathrm{Ln}_{2} \mathrm{NiO}_{4+\delta}$ phases have the orthorhombic crystal structure with Fmmm space group, while $\mathrm{Ln}_{1.7} \mathrm{Ca}_{0.3} \mathrm{NiO}_{4+\delta}$ phases possess the tetragonal crystal structure with $14 / \mathrm{mmm}$ space group. The data obtained for both undoped and doped oxide systems reveal a reduction in the lattice parameters and the unit cell volume with the decrease in the ionic radius of the lanthanide $\left(r \mathrm{La}^{+3}{ }_{\mathrm{IX}}=1.216 \AA ; r \mathrm{Pr}^{+3}{ }_{\mathrm{IX}}=1.179 \AA ; r \mathrm{Nd}^{+3}{ }_{\mathrm{IX}}=1.163 \AA\right.$ [18] $)$ due to a dimensional effect. There are two possible causes for decrease in these values when doping with calcium. Firstly, for $\mathrm{Ln}=\mathrm{La}, \mathrm{Pr}$, it is due to their substitution with the element possessing a smaller ionic radius $\left(r \mathrm{Ca}^{2+}{ }_{\mathrm{IX}}=1.18 \AA\right)$. Secondly, for all members in the series $\mathrm{Ln}=\mathrm{La}, \mathrm{Pr}, \mathrm{Nd}$, a partial replacing $\mathrm{Ni}^{2+}{ }_{\mathrm{VI}}(r=0.69 \AA)$ in $\mathrm{Ln}_{2} \mathrm{NiO}_{4+\delta}$ structure by $\mathrm{Ni}^{3+}{ }_{\mathrm{VI}}\left(r=0.566_{\mathrm{LS}} \AA\right.$; $0.60_{\mathrm{HS}} \AA$ ) owing to charge compensation can also result in parameters decreasing, and this reason seems to prevail in the case of $\mathrm{Nd}_{1.7} \mathrm{Ca}_{0.3} \mathrm{NiO}_{4+\delta}$. Structural parameters for $\mathrm{Ln}_{2-\mathrm{x}} \mathrm{Ca}_{\mathrm{x}} \mathrm{NiO}_{4+\delta}$ oxide systems calculated by the Rietveld method are shown in Table 1 . 
$10^{\mathrm{TH}}$ InTERnATIONAL CONFERENCE ON Sustainable ENERgy AND ENVIRONMENTAL Protection (June $27^{\mathrm{TH}}-30^{\mathrm{TH}}, 2017$, Bled, Slovenia), Hydrogen and Fuel Cells V. A. Sadykov, E. Yu. Pikalova, A. A. Kolchugin, N. F. Eremeev, N. M. Bogdanovich, A. F. Khasanov, P. I. Skriabin, A. V. Krasnov, E. M. Sadovskaya, A. N. Shmakov, Z. S. Vinokurov, A. V. Ishchenko, S. M. Pikalov \& E. A. Filonova: Transport Properties of Ca-Doped $\mathrm{Ln}_{2} \mathrm{NiO}_{4}$

Table 1. The structural parameters of $\mathrm{Ln}_{2-\mathrm{x}} \mathrm{Ca}_{x} \mathrm{NiO}_{4+\delta}$

\begin{tabular}{|c|c|c|c|c|c|c|}
\hline Sample & LNO & LCNO & PNO & PCNO & NNO & NCNO \\
\hline$a,[\AA]$ & $\begin{array}{c}5.4581( \\
2)\end{array}$ & $3.8288(1)$ & $\begin{array}{c}5.3923( \\
2)\end{array}$ & $3.8057(1)$ & $\begin{array}{c}5.3759( \\
1)\end{array}$ & $3.7992(1)$ \\
\hline$b,[\AA]$ & $\begin{array}{c}5.4656( \\
2)\end{array}$ & $3.8288(1)$ & $\begin{array}{c}5.4610( \\
2)\end{array}$ & $3.8057(1)$ & $\begin{array}{c}5.4596( \\
1)\end{array}$ & $3.7992(1)$ \\
\hline$c,[\AA]$ & $\begin{array}{c}12.6755 \\
(4)\end{array}$ & $12.5984(2)$ & $\begin{array}{c}12.4441 \\
(5)\end{array}$ & $\begin{array}{c}12.3947( \\
3)\end{array}$ & $\begin{array}{c}12.3652 \\
(3)\end{array}$ & $12.2927(2)$ \\
\hline$V,\left[\AA^{3}\right]$ & $\begin{array}{c}378.13( \\
3)\end{array}$ & $184.69(1)$ & $\begin{array}{c}366.45( \\
2)\end{array}$ & $179.52(1)$ & $\begin{array}{c}362.92( \\
1)\end{array}$ & $177.44(1)$ \\
\hline $\begin{array}{c}\text { Occ. } \\
(\mathrm{R} / \mathrm{Ca})\end{array}$ & $2.08(1)$ & $\begin{array}{c}1.74(1) / 0.3 \\
4(1)\end{array}$ & $2.15(2)$ & $\begin{array}{c}1.78(1) / 0 \\
.38\end{array}$ & $2.18(1)$ & $\begin{array}{c}1.75(1) / 0.3 \\
5(1)\end{array}$ \\
\hline $\begin{array}{c}B_{\text {overall }}[\mathrm{[} \\
\left.\mathrm{A}^{2}\right]\end{array}$ & $0.33(4)$ & $0.42(4)$ & $0.41(7)$ & $1.10(4)$ & $0.52(5)$ & $0.68(1)$ \\
\hline$R_{B \mathrm{r}}$ & 4.13 & 2.91 & 3.41 & 3.45 & 2.92 & 2.59 \\
\hline$R f$ & 2.42 & 2.41 & 2.09 & 2.63 & 1.79 & 2.01 \\
\hline$\delta$ & $0.17(1)$ & $0.01(1)$ & $0.21(1)$ & $0.04(1)$ & $0.22(1)$ & $0.05(1)$ \\
\hline
\end{tabular}

Hyperstoichiometric oxygen content $\delta$ in $\mathrm{Ln}_{2} \mathrm{NiO}_{4+\delta}$ is determined by the nature of the $\mathrm{Ln}$ cation and increases as $\mathrm{Ln}$ radius decreases in the series of $\mathrm{La}_{2} \mathrm{NiO}_{4+\delta}(0.17)<\mathrm{Pr}_{2} \mathrm{NiO}_{4+\delta}$ $(0.21)<\mathrm{Nd}_{2} \mathrm{NiO}_{4+\delta}(0.22)$. The phase transition from the orthorhombic to the tetragonal lattice, as observed in all $\mathrm{Ln}_{1.7} \mathrm{Ca}_{0.3} \mathrm{NiO}_{4+\delta}$ materials, is associated with a sharp decrease in the amount of hyperstoichiometric oxygen which was equal to $0.01,0.04$ and 0.05 for $\mathrm{La}_{1.7} \mathrm{Ca}_{0.3} \mathrm{NiO}_{4+\delta}, \quad \mathrm{Pr}_{1.7} \mathrm{Ca}_{0.3} \mathrm{NiO}_{4+\delta}$ and $\mathrm{Nd}_{1.7} \mathrm{Ca}_{0.3} \mathrm{NiO}_{4+\delta}$, respectively. Calculations carried out on the refinement of the occupation coefficients of cationic positions Occ. (Ln / Ca), presented in Table 1, qualitatively confirm both a tendency to increase $\delta$ in the $\mathrm{Ln}_{2} \mathrm{NiO}_{4+\delta}$ series and a tendency to decrease $\delta$ with calcium doping. An increase in the temperature factor $B_{\text {overall }}$ from $\mathrm{Ln}_{2} \mathrm{NiO}_{4+\delta}$ to $\mathrm{Ln}_{1.7} \mathrm{Ca}_{0.3} \mathrm{NiO}_{4+\delta}$ reflects disordering of the lattice with doping.

According to TEM data, very large particles $(\sim 200-1500 \mathrm{~nm})$ are typical for all samples, which may be caused by a high $\left(1100-1250{ }^{\circ} \mathrm{C}\right)$ sintering temperature. Small nanoparticles probably corresponding to $\mathrm{CaO}$ segregation were observed as well. In general, the interplanar distances observed correlate well with those for $\mathrm{La}_{2} \mathrm{NiO}_{4}$ tetragonal structure (ICSD-PDF\#70-509): (002) 6.3415 $\AA$, (101) $3.7068 \AA,(004)$ $3.1707 \AA$, (103) $2.8570 \AA$, (110) $2.7408 \AA$, (112) $2.5158 \AA$, (105) $2.1225 \AA$ and (006) $2.1138 \AA$. Insignificant difference with the standard values can be explained by variation of the local cation composition without substantial distortion of the anion sublattice. $1-3 \mathrm{~nm}$ thick amorphous layer and/or amorphous nanoparticles are present on the surface of particles (Fig. 1). The other extended defects such as cluster inclusions, grain boundaries and 
$10^{\mathrm{TH}}$ INTERNATIONAL CONFERENCE ON SUSTAINABLE ENERGY AND ENVIRONMENTAL Protection (June $27^{\mathrm{TH}}-30^{\mathrm{TH}}, 2017$, Bled, SLovenia), EnERgy Storage

V. A. Sadykov, E. Yu. Pikalova, A. A. Kolchugin, N. F. Eremeev, N. M. Bogdanovich, A. F. Khasanov, P. I. Skriabin, A. V. Krasnov, E. M. Sadovskaya, A. N. Shmakov, Z. S. Vinokurov, A. V. Ishchenko, S. M. Pikalov \& E. A. Filonova: Transport Properties of Ca-Doped $\mathrm{Ln}_{2} \mathrm{NiO}_{4}$

stacking faults were revealed for all samples (especially for those containing $\mathrm{Nd}$; Fig. 1, a, b).

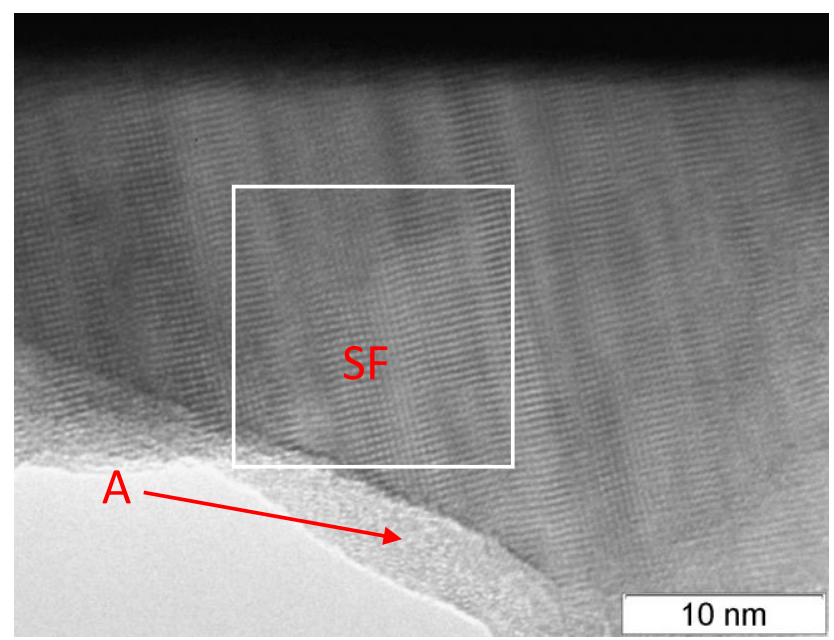

(a)

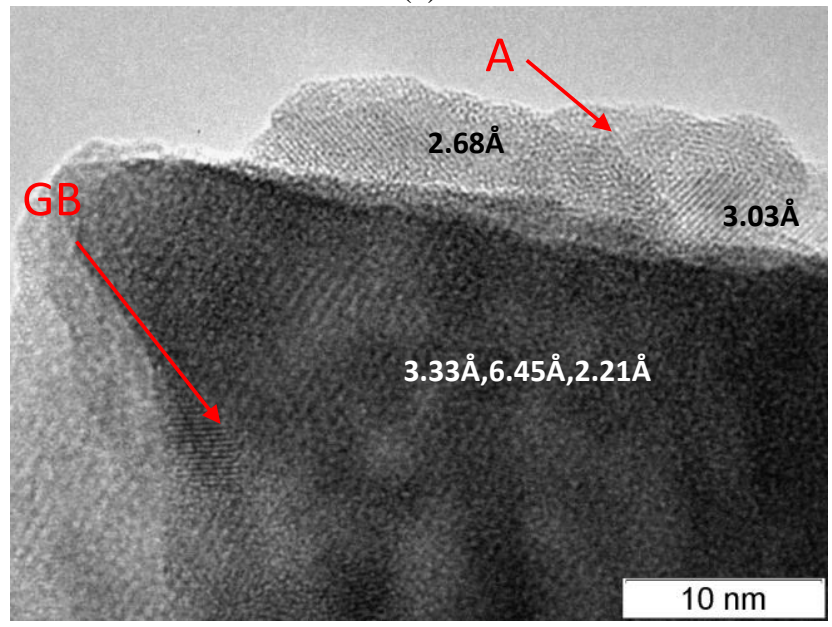

(b)

Figure 1. High resolution TEM micrographs for $\mathrm{Nd}_{2} \mathrm{NiO}_{4+\delta}$ (a) and $\mathrm{Nd}_{1.7} \mathrm{Ca}_{0.3} \mathrm{NiO}_{4+\delta}$ (b) samples. I - inclusions, A - amorphous surface layers, GB - grain boundaries.

\subsection{Electrical conductivity}

Fig. 2 shows electrical conductivity vs $T$ plots for $\mathrm{Ln}_{2-\mathrm{x}} \mathrm{Ca}_{\mathrm{x}} \mathrm{NiO}_{4+\delta}$ samples. Doping with $\mathrm{Ca}$ results in enhancement of electrical conductivity. This is due to increasing concentration of electron holes while placing $\mathrm{Ca}^{2+}$ cations into the positions of $\mathrm{Ln}^{3+}$ 
$10^{\mathrm{TH}}$ International Conference on Sustainable EnERgy and Environmental Protection (June $27^{\mathrm{TH}}-30^{\mathrm{TH}}, 2017$, Bled, Slovenia), Hydrogen and Fuel Cells

V. A. Sadykov, E. Yu. Pikalova, A. A. Kolchugin, N. F. Eremeev, N. M. Bogdanovich, A. F. Khasanov, P. I. Skriabin, A. V. Krasnov, E. M. Sadovskaya, A. N. Shmakov, Z. S. Vinokurov, A. V. Ishchenko, S. M. Pikalov \& E. A. Filonova: Transport Properties of Ca-Doped $\mathrm{Ln}_{2} \mathrm{NiO}_{4}$

cations. The effective activation energy values are $2.4,5.5,4.8,7.8,6.4$ and $6.7 \mathrm{~kJ} / \mathrm{mole}$ for $\quad \mathrm{La}_{2} \mathrm{NiO}_{4+\delta}, \quad \mathrm{La}_{1.7} \mathrm{Ca}_{0.3} \mathrm{NiO}_{4+\delta}, \quad \mathrm{Pr}_{2} \mathrm{NiO}_{4+\delta}, \quad \mathrm{Pr}_{1.7} \mathrm{Ca}_{0.3} \mathrm{NiO}_{4+\delta}, \quad \mathrm{Nd}_{2} \mathrm{NiO}_{4+\delta} \quad$ and $\mathrm{Nd}_{1.7} \mathrm{Ca}_{0.3} \mathrm{NiO}_{4+\delta}$, respectively.

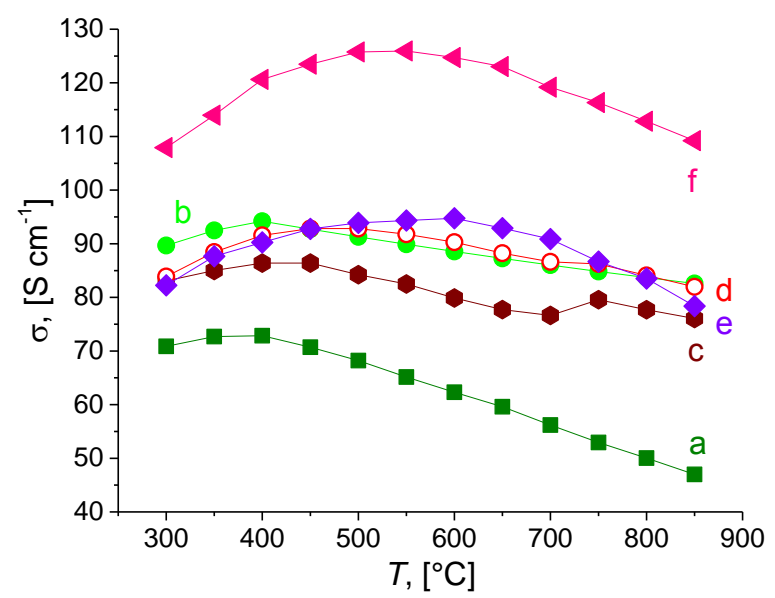

Figure 2. Conductivity of the compact samples: $\mathrm{La}_{2} \mathrm{NiO}_{4+\delta}$ (a), $\mathrm{La}_{1.7} \mathrm{Ca}_{0.3} \mathrm{NiO}_{4+\delta}$ (b), $\mathrm{Pr}_{2} \mathrm{NiO}_{4+\delta}$ (c), $\mathrm{Pr}_{1.7} \mathrm{Ca}_{0.3} \mathrm{NiO}_{4+\delta}$ (d). $\mathrm{Nd}_{2} \mathrm{NiO}_{4+\delta}$ (e) and $\mathrm{Nd}_{1.7} \mathrm{Ca}_{0.3} \mathrm{NiO}_{4+\delta}$ (f).

\subsection{Oxygen mobility and surface reactivity}

\section{Temperature programmed isotope exchange of oxygen}

For undoped $\mathrm{Ln}_{2} \mathrm{NiO}_{4+\delta}$ samples the oxygen isotope heteroexchange starts at $\sim 200{ }^{\circ} \mathrm{C}$. Doping by $\mathrm{Ca}$ increases this temperature by $\sim 100-200{ }^{\circ} \mathrm{C}$. For $\mathrm{La}_{1.7} \mathrm{Ca}_{0.3} \mathrm{NiO}_{4+\delta}$ two TPIE peaks corresponding with two types of oxygen were observed. The atomic fraction of oxygen involved in the exchange during TPIE run (extent of exchange) is $80-90 \%$ for both undoped and doped samples.

According to modelling results the oxygen isotope exchange process is as described by the $\mathrm{R}^{1}$ type of exchange mechanism by Muzykantov's classification [15,19] with participation of the surface oxygen atom and without dissociation of the $\mathrm{CO}_{2}$ molecule. Typical oxygen surface exchange constant $\left(k_{e x}\right)$ values are $\sim 10^{-4} \mathrm{~cm} \mathrm{~s}^{-1}$ at $700{ }^{\circ} \mathrm{C}$ for undoped samples as well as for $\operatorname{Pr}_{1.7} \mathrm{Ca}_{0.3} \mathrm{NiO}_{4+\delta}$ and $\sim 10^{-5} \mathrm{~cm} \mathrm{~s}^{-1}$ for $\mathrm{La}_{1.7} \mathrm{Ca}_{0.3} \mathrm{NiO}_{4+\delta}$ (Fig. 3, top image). It is to be noted that these $k^{*}$ values for exchange with $\mathrm{C}^{18} \mathrm{O}_{2}$ are $\sim 2$ orders of magnitude higher as compared to those for exchange with ${ }^{18} \mathrm{O}_{2}$ [20].

Typical $D_{O}$ values are $\sim 10^{-8} \mathrm{~cm}^{2} \mathrm{~s}^{-1}$ at $700{ }^{\circ} \mathrm{C}$ (Fig. 3, bottom image). These data concur closely with the results obtained earlier by isotope exchange of oxygen with ${ }^{18} \mathrm{O}_{2}$ [14]. Emergence of an additional channel of slow oxygen diffusion (Fig. 3, b) observed as separate peaks in TPIE curves (not shown for brevity) was revealed for $\mathrm{La}_{1.7} \mathrm{Ca}_{0.3} \mathrm{NiO}_{4+\delta}$. 
V. A. Sadykov, E. Yu. Pikalova, A. A. Kolchugin, N. F. Eremeev, N. M. Bogdanovich,

A. F. Khasanov, P. I. Skriabin, A. V. Krasnov, E. M. Sadovskaya, A. N. Shmakov, Z. S.

Vinokurov, A. V. Ishchenko, S. M. Pikalov \& E. A. Filonova: Transport Properties of

Ca-Doped $\mathrm{Ln}_{2} \mathrm{NiO}_{4}$

Observed trend in decreasing the oxygen mobility with Ca doping is caused by reducing the amount of highly mobile interstitial oxygen and hampering the cooperative mechanism of oxygen migration involving oxygen in interstitial and regular positions [9].
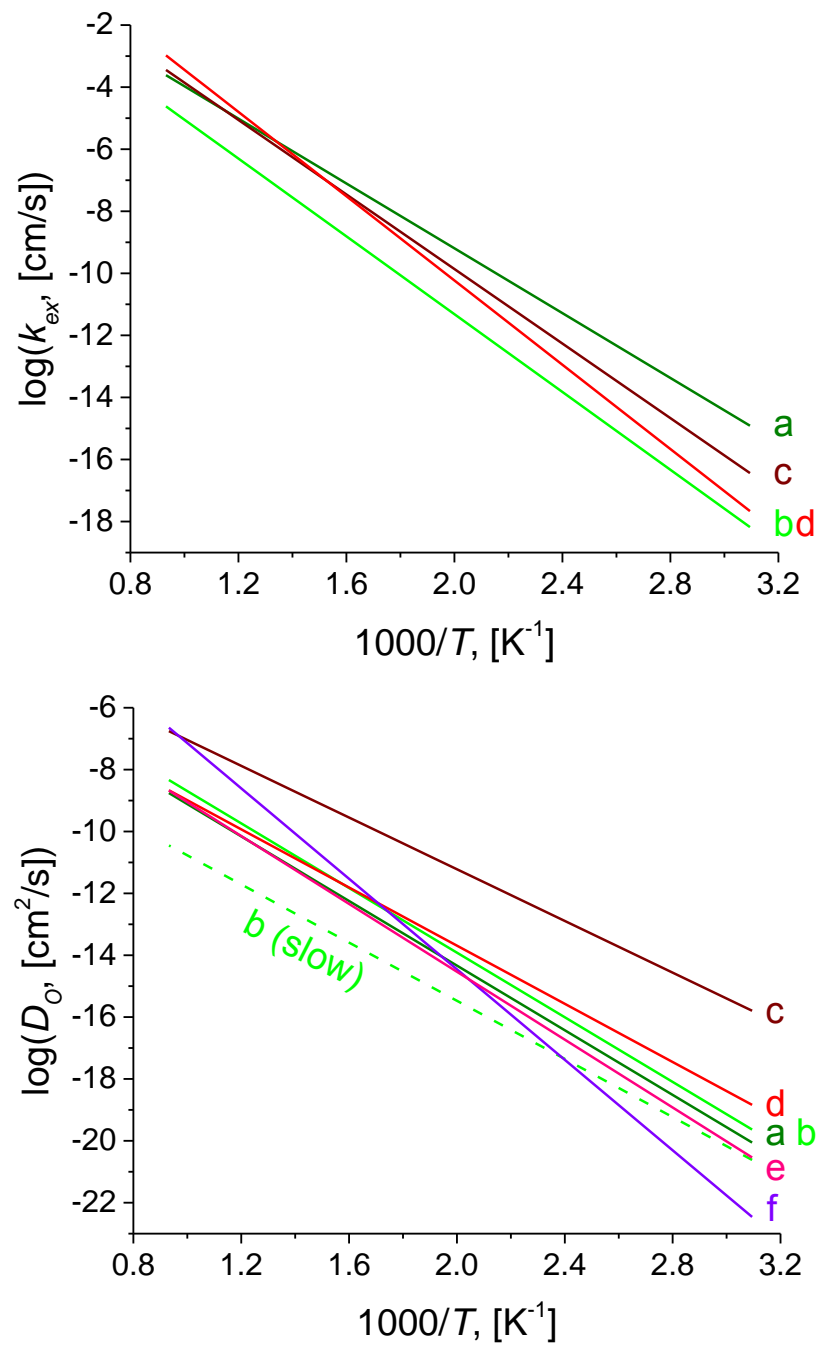

Figure 3. Arrhenius plots of oxygen surface exchange constants (top picture) and tracer diffusion coefficients (bottom picture) for $\mathrm{La}_{2} \mathrm{NiO}_{4+\delta}(\mathrm{a}), \mathrm{La}_{1.7} \mathrm{Ca}_{0.3} \mathrm{NiO}_{4+\delta}$ (b), $\mathrm{Pr}_{2} \mathrm{NiO}_{4+\delta}$ (c), $\mathrm{Pr}_{1.7} \mathrm{Ca}_{0.3} \mathrm{NiO}_{4+\delta}$ (d). $\mathrm{Nd}_{2} \mathrm{NiO}_{4+\delta}$ (e) and $\mathrm{Nd}_{1.7} \mathrm{Ca}_{0.3} \mathrm{NiO}_{4+\delta}$ (f) samples calculated from TPIE data. 
$10^{\mathrm{TH}}$ InTERnAtional CONFERENCE ON Sustainable ENERgy AND ENVIRONMENTAL Protection (June $27^{\mathrm{TH}}-30^{\mathrm{TH}}, 2017$, Bled, Slovenia), Hydrogen and Fuel Cells V. A. Sadykov, E. Yu. Pikalova, A. A. Kolchugin, N. F. Eremeev, N. M. Bogdanovich, A. F. Khasanov, P. I. Skriabin, A. V. Krasnov, E. M. Sadovskaya, A. N. Shmakov, Z. S. Vinokurov, A. V. Ishchenko, S. M. Pikalov \& E. A. Filonova: Transport Properties of Ca-Doped $\mathrm{Ln}_{2} \mathrm{NiO}_{4}$

A fast diffusion channel corresponds to a cooperative mechanism, while slow ones are related to transport in perovskite layers and complicated interlayer positions near the dopant cation sites.

\section{Unit cell volume relaxation}

Oxygen mobility and surface reactivity characteristics under the gradient of chemical potential are close to those for previously studied R-P oxides [9]. Typical values of chemical diffusion coefficient at $700{ }^{\circ} \mathrm{C}$ are $\sim 10^{-5} \mathrm{~cm}^{2} / \mathrm{s}$.

\section{$4 \quad$ Conclusions}

The structure, oxygen mobility and surface reactivity of $\mathrm{Ln}_{2-\mathrm{x}} \mathrm{Ca}_{x} \mathrm{NiO}_{4+\delta}(\mathrm{Ln}=\mathrm{La}, \mathrm{Pr}, \mathrm{Nd}$; $x=0,0.3$ ) were studied. The relationship between the structural and transport properties of these materials was established. The hyperstoichiometric oxygen content $\delta$ was found to increase when the ionic radius of the lanthanide decreases.

Doping with Ca was shown to decrease $\delta$ and increase the electrical conductivity. The co-existence of several channels of oxygen migration in layered nickelates was revealed and explained by the effect of the doping cation on the content of highly mobile interstitial oxygen atoms and barrier for oxygen migration. A high overall oxygen mobility of Ruddlesden-Popper phases $\mathrm{Ln}_{2-\mathrm{x}} \mathrm{Ca}_{x} \mathrm{NiO}_{4+\delta}(\mathrm{Ln}=\mathrm{Pr}, \mathrm{Nd})$ along with their stability allows us to conclude that the materials involved are promising for application as cathodes of intermediate temperature solid oxide fuel cells and functional layers of oxygen separation membranes.

\section{Acknowledgements}

Structure and electric conductivity studies were supported by Government of the Russian Federation (Agreement 02.A03.21.0006, Act 211). Microscopy and oxygen mobility studies were supported by Russian Science Foundation (Project 16-13-00112). Support of shared-access centers "Composition of compounds" and "Ural-M" is gratefully acknowledged.

\section{References}

[1] V. Sadykov, V. Usoltsev, Yu. Fedorova, N. Mezentseva, T. Krieger, N. Eremeev, M. Arapova, A. Ishchenko, A. Salanov, V. Pelipenko, V. Muzykantov, A. Ulikhin, N. Uvarov, O. Bobrenok, A. Vlasov, M. Korobeynikov, A. Bryazgin, A. Arzhannikov, P. Kalinin, O. Smorygo, and M. Thumm, "Advanced sintering techniques in design of planar IT SOFC and supported oxygen separation membranes" in Sintering of ceramics - New emerging techniques. Vienna: InTech, 2012. pp. $121-140$.

[2] Y. Lee, and H. Kim, "Electrochemical performance of $\mathrm{La}_{2} \mathrm{NiO}_{4+\delta}$ cathode for intermediatetemperature solid oxide fuel cells," Ceram. Int., vol. 41, pp. 5984-5991, May 2015. 
$10^{\mathrm{TH}}$ INTERNATIONAL CONFERENCE ON SUSTAINABLE ENERGY AND ENVIRONMENTAL Protection (June $27^{\mathrm{TH}}-30^{\mathrm{TH}}, 2017$, Bled, Slovenia), ENERGy Storage V. A. Sadykov, E. Yu. Pikalova, A. A. Kolchugin, N. F. Eremeev, N. M. Bogdanovich, A. F. Khasanov, P. I. Skriabin, A. V. Krasnov, E. M. Sadovskaya, A. N. Shmakov, Z. S. Vinokurov, A. V. Ishchenko, S. M. Pikalov \& E. A. Filonova: Transport Properties of Ca-Doped $\mathrm{Ln}_{2} \mathrm{NiO}_{4}$

[3] C. Nicollet, A. Flura, V. Vibhu, A. Rougier, J. M. Bassat, and J. C. Grenier, "La ${ }_{2} \mathrm{NiO}_{4+\delta}$ infiltrated into gadolinium doped ceria as novel solid oxide fuel cell cathodes: Electrochemical performance and impedance modelling," J. Power Sources, vol. 294, pp. 473-482, Oct. 2016.

[4] R. J. Woolley, and S. J. Skinner, "Functionally graded composite $\mathrm{La}_{2} \mathrm{NiO}_{4+\delta}$ and $\mathrm{La}_{4} \mathrm{Ni}_{3} \mathrm{O}_{10-\delta}$ solid oxide fuel cell cathodes," Solid State Ionics, vol. 255, pp. 1-5, Feb. 2014.

[5] K. Zhao, Y.-P. Wang, M. Chen, Q. Xu, B.-H. Kim, and D.-P. Huang, "Electrochemical evaluation of $\mathrm{La}_{2} \mathrm{NiO}_{4+\delta}$ as a cathode material for intermediate temperature solid oxide fuel cells," Int. J. Hydrogen Energy, vol. 39, pp. 7120-7130, Apr. 2014.

[6] B. Philippeau, F. Mauvy, C. Mazataud, S. Fourcade, and J.-C. Grenier, "Comparative study of electrochemical properties of mixed conducting $\mathrm{Ln}_{2} \mathrm{NiO}_{4+\delta}(\mathrm{Ln}=\mathrm{La}, \mathrm{Pr}$ and $\mathrm{Nd})$ and La0.6 $\mathrm{Sr}_{0.4} \mathrm{Fe}_{0.8} \mathrm{Co}_{0.2} \mathrm{O}_{3-\delta}$ as SOFC cathodes associated to $\mathrm{Ce}_{0.9} \mathrm{Gdd}_{0.1} \mathrm{O}_{2-\delta}$, $\mathrm{La}_{0.8} \mathrm{Sr}_{0.2} \mathrm{Ga}_{0.8} \mathrm{Mg}_{0.2} \mathrm{O}_{3-\delta}$ and $\mathrm{La}_{9} \mathrm{Sr}_{1} \mathrm{Si}_{6} \mathrm{O}_{26.5}$ electrolytes," Solid State Ionics, vol. 249, pp. 17-25, Nov. 2013.

[7] V. A. Sadykov, N. F. Eremeev, E. M. Sadovskaya, A. S. Bobin, Yu. E. Fedorova, V. S. Muzykantov, N. V. Mezentseva, G. M. Alikina, T. A. Kriger, V. D. Belyaev, V. A. Rogov, A. S. Ulikhin, Yu. S. Okhlupin, N. F. Uvarov, O. F. Bobrenok, N. McDonald, J. Watton, A. Dhir, R. Steinberger-Wilckens, J. Mertens, and I. C. Vinke, "Cathodic materials for intermediate-temperature solid oxide fuel cells based on praseodymium nickelatescobaltites," Russ. J. Electrochem., vol. 50, pp. 669-679, Jul. 2014.

[8] C. Ferchaud, J.-C. Grenier, Y. Zhang-Steenwinkel, M. M. A. van Tuel, F. P. F. van Berkel, and J.-M. Bassat, "High performance praseodymium nickelate oxide cathode for low temperature solid oxide fuel cell," J. Power Sources, vol. 196, pp. 1872-1879, Feb. 2011.

[9] V. Sadykov, Yu. Okhlupin, N. Yeremeev, Z. Vinokurov, A. Shmakov, V. Belyaev, N. Uvarov, and J. Mertens, "In situ X-ray diffraction studies of $\operatorname{Pr}_{2-x} \mathrm{NiO}_{4+\delta}$ crystal structure relaxation caused by oxygen loss,” Solid State Ionics, vol. 262, pp. 918-922, Sep. 2014.

[10] V. A. Sadykov, N. F. Eremeev, V. V. Usol'tsev, A. S. Bobin, G. M. Alikina, V. V. Pelipenko, E. M. Sadovskaya, V. S. Muzykantov, N. N. Bulgakov, and N. F. Uvarov, "Mechanism of oxygen transfer in layered lanthanide nickelates $\mathrm{Ln}_{2-x} \mathrm{NiO}_{4+\delta}(\mathrm{Ln}=\mathrm{La}, \mathrm{Pr})$ and their nanocomposites with $\mathrm{Ce}_{0.9} \mathrm{Gd}_{0.1} \mathrm{O}_{2-\delta}$ and $\mathrm{Y}_{2}\left(\mathrm{Ti}_{0.8} \mathrm{Zr}_{0.2}\right)_{1.6} \mathrm{Mn}_{0.4} \mathrm{O}_{7-\delta}$ solid electrolytes," Russ. J. Electrochem., vol. 49, pp. 645-651, Jul. 2013.

[11] E. Yu. Pikalova, N. Bogdanovich, A. Kolchugin, D. A. Osinkin, and D. I. Bronin, "Electrical and electrochemical properties of $\mathrm{La}_{2} \mathrm{NiO}_{4+\delta}$-based cathodes in contact with $\mathrm{Ce}_{0.8} \mathrm{Sm}_{0.2} \mathrm{O}_{2-\delta}$ electrolyte," Procedia Eng., vol. 98, pp. 105-110, 2014.

[12] X. Li, and N. A. Benedek, "Enhancement of Ionic transport in complex oxides through soft lattice modes and epitaxial strain," Chem. Mater. American Chemical Society, vol. 27, pp. 2647-2652, Apr. 2015.

[13] E. Yu. Pikalova, N. F. Eremeev, A. A. Kolchugin, E. M. Sadovskaya, V. V. Pelipenko, N. M. Bogdanovich, E. A. Filonova, and V. A. Sadykov, "Structural, electrical and electrochemical characteristics and oxygen transport properties of the alkaline earth metal doped $\mathrm{Ln}_{2} \mathrm{NiO}_{4}$," presented at the 12th International Symposium on Systems with Fast Ionic Transport (ISSFIT-12), Kaunas, 2016, p. 75.

[14] A. A. Kolchugin, E. Yu. Pikalova, N. M. Bogdanovich, D. I. Bronin, S. M. Pikalov, S. V. Plaksin, M. V. Ananyev, and V. A. Eremin, "Structural, electrical and electrochemical properties of calcium-doped lanthanum nickelate," Solid State Ionics, vol. 288, pp. 48-53, May 2016. 
$10^{\text {Th }}$ International Conference on Sustainable Energy and Environmental Protection (June 27 $7^{\mathrm{TH}}-30^{\mathrm{TH}}, 2017$, Bled, Slovenia), Hydrogen ANd Fuel Cells

V. A. Sadykov, E. Yu. Pikalova, A. A. Kolchugin, N. F. Eremeev, N. M. Bogdanovich, A. F. Khasanov, P. I. Skriabin, A. V. Krasnov, E. M. Sadovskaya, A. N. Shmakov, Z. S. Vinokurov, A. V. Ishchenko, S. M. Pikalov \& E. A. Filonova: Transport Properties of Ca-Doped $\mathrm{Ln}_{2} \mathrm{NiO}_{4}$

[15] V. A. Sadykov, E. M. Sadovskaya, and N. F. Uvarov, "Methods of isotopic relaxations for estimation of oxygen diffusion coefficients in solid electrolytes and materials with mixed ionic-electronic conductivity," Russ. J. Electrochem., vol. 51, pp. 458-467, May 2015.

[16] D. D. Frolov, Yu. N. Kotovshchikov, I. V. Morozov, A. I. Boltalin, A. A. Fedorova, A. V. Marikutsa, M. N. Rumyantseva, A. M. Gaskov, E. M. Sadovskaya, and A. M. Abakumov, "Oxygen exchange on nanocrystalline tin dioxide modified by palladium," J. Solid State Chem., vol. 186, pp. 1-8, Feb. 2012.

[17] V. Sadykov, E. Sadovskaya, A. Bobin, T. Kharlamova, N. Uvarov, A. Ulikhin, C. Argirusis, G. Sourkouni, and V. Stathopoulos, "Temperature-programmed $\mathrm{C}^{18} \mathrm{O}_{2}$ SSITKA for powders of fast oxide-ion conductors: Estimation of oxygen self-diffusion coefficients," Solid State Ionics, vol. 271, pp. 69-72, Mar. 2015.

[18] R. D. Shannon, and C. T. Prewitt, "Effective ionic radii in oxides and fluorides," Acta Crystallogr. Sect. B Struct. Crystallogr. Cryst. Chem., vol. 25, pp. 925-946. May 1969.

[19] V. Muzykantov, V. Popovskii, and G. Boreskov, "Kinetics of isotope exchange in a molecular oxygen - solid oxide system," Kinet. Catal., vol. 5, pp. 624-629, Jul. 1964.

[20] V. A. Sadykov, N. F. Eremeev, V. A. Bolotov, Yu. Yu. Tanashev, Yu. E. Fedorova, D. G. Amanbayeva, A. S. Bobin, E. M. Sadovskaya, V. S. Muzykantov, V. V. Pelipenko, A. I. Lukashevich, T. A. Krieger, A. V. Ishchenko, and A. L. Smirnova, "The effect of microwave sintering on stability and oxygen mobility of praseodymium nickelatescobaltites and their nanocomposites," Solid State Ionics, vol. 288, pp. 76-81, May 2016. 
$10^{\mathrm{TH}}$ INTERNATIONAL CONFERENCE ON Sustainable ENERgy AND ENVIRONMENTAL Protection (June $27^{\mathrm{TH}}-30^{\mathrm{TH}}$, 2017, Bled, Slovenia), Hydrogen ANd Fuel Cells

J. Krope, A.Ghani Olabi, D. Goričanec \& S. Božičnik

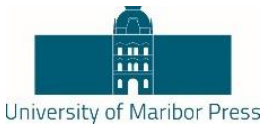

\title{
Novel Nanocomposite Materials for Oxygen Separation Membranes
}

\author{
Vladislav A. Sadykov, Alexey V. Krasnov, Yulia E. Fedorova, Anton I. \\ LuKASHEVICH, Nikita F. EREMEEV, PAVEL I. SKRIABIN, KonSTANTIN R. VALEEV \& \\ OLEG L. SMORYGO
}

\begin{abstract}
Nanocomposites based on Pr nickelate-cobaltite are promising materials due to a high oxygen mobility and relatively good chemical stability in working conditions. This work aims at studying performance of membranes based on such nanocomposite. A few $\operatorname{PrNi}_{0.5} \mathrm{Co}_{0.5} \mathrm{O}_{3} \delta-\mathrm{Ce}_{0.9}$ $\mathrm{Y}_{0.1} \mathrm{O}_{2} \delta$ functional layers, $\mathrm{MnFe}_{2} \mathrm{O}_{4}-\mathrm{Ce}_{0.9} \mathrm{Gd}_{0.1} \mathrm{O}_{2} \delta$ buffer layer and $\mathrm{Pt} / \mathrm{Sm}_{0.15} \mathrm{Pr}_{0.15} \mathrm{Ce}_{0.35} \mathrm{Zr}_{0.3} \mathrm{O}_{2-\delta}+\mathrm{LaNi}_{0.9} \mathrm{Pt}_{0.1} \mathrm{O}_{3} / \mathrm{Pr}_{0.3} \mathrm{Ce}_{0.35} \mathrm{Zr}_{0.35} \mathrm{O}_{2-\delta} / \mathrm{Al}_{2} \mathrm{O}_{3}$ catalytic layers were consecutively deposed on $\mathrm{Ni} / \mathrm{Al}$ foam substrate. The selectivity of methane oxidation into syngas increases with the inlet methane concentration which is typical for such membranes. $\mathrm{CH}_{4}$ conversion is up to $50 \%$ with $\mathrm{H}_{2}$ content in the outlet feed being up to 25 $\%$ at $900{ }^{\circ} \mathrm{C}$. $\mathrm{H}_{2} / \mathrm{CO}$ concentration ratio is $>1$. Hence, performance characteristics of the membrane demonstrate that these materials are promising for the practical application.
\end{abstract}

Keywords: • oxygen separation membranes • nanocomposites $\bullet$ methane conversion • oxi-dry reforming • testing •

CoRRESPONDENCE AdDRESS: Vladislav A. Sadykov, Prof. Dr., Head of laboratory, Boreskov Institute of Catalysis SB RAS, pr. Akad. Lavrentieva 5, Novosibirsk 630090, Russia, Novosibirsk State University, Pirogova str. 2, Novosibirsk 630090, Russia, e-mail: sadykov@ catalysis.ru. Alexey V. Krasnov, Engineer, Boreskov Institute of Catalysis SB RAS, pr. Akad. Lavrentieva 5, Novosibirsk 630090, Russia, e-mail: leadenskyes@gmail.com. Yulia E. Fedorova, Engineer, Boreskov Institute of Catalysis SB RAS, pr. Akad. Lavrentieva 5, Novosibirsk 630090, Russia, e-mail: fedorova@ catalysis.ru. Anton I. Lukashevich, Junior researcher, Boreskov Institute of Catalysis SB RAS, pr. Akad. Lavrentieva 5, Novosibirsk 630090, Russia, email: toshik@yandex.ru. Nikita F. Eremeev, PhD, Researcher, Boreskov Institute of Catalysis SB RAS, pr. Akad. Lavrentieva 5, Novosibirsk 630090, Russia, e-mail: yeremeev21@gmail.com. Pavel I. Skriabin, Junior researcher, Boreskov Institute of Catalysis SB RAS, pr. Akad. Lavrentieva 5, Novosibirsk 630090, Russia, email: ivanovich1401@gmail.com. Konstantin R. Valeev, Junior researcher, Boreskov Institute of Catalysis SB RAS, pr. Akad. Lavrentieva 5, Novosibirsk 630090, Russia, e-mail: valeev@ catalysis.ru. Oleg L. Smorygo, Docent Dr., Head of laboratory, Powder Metallurgy Institute, Platonova str. 41, Minsk 220005, Republic of Belarus, e-mail: smorygo@ rambler.ru.

https://doi.org/10.18690/978-961-286-054-7.9

ISBN 978-961-286-054-7

(C) 2017 University of Maribor Press

Available at: http://press.um.si. 
$10^{\mathrm{TH}}$ InTERnAtional CONFERENCE ON Sustainable ENERGy AND ENVIRONMENTAL Protection (June $27^{\mathrm{TH}}-30^{\mathrm{TH}}, 2017$, Bled, Slovenia), Hydrogen and Fuel Cells V. A. Sadykov, A. V. Krasnov, Y. E. Fedorova, A. I. Lukashevich, N. F. Eremeev, P. I. Skriabin, K. R. Valeev \& O. L. Smorygo: Novel Nanocomposite Materials for Oxygen Separation Membranes

A key problem of modern hydrogen energy is producing hydrogen and syngas from biofuels in catalytic reactors using oxygen as a reagent [1-4]. Oxygen separation membranes produce syngas from fuels by their selective oxidation with oxygen separated from air [5-7]. The membrane typically consists of metallic or cermet foam substrate with a few functional layers with various porosity, a dense buffer layer and porous catalytic ones deposed on the fuel side [8,9]. Oxides and nanocomposites with high mixed ionic-electronic conductivity/oxygen mobility are used as materials for functional and buffer layers of these devices.

Recently we reported about our advances in design and testing membranes based on praseodymium nickelate-cobaltite - yttria doped ceria nanocomposite [6,7]. Stable to carbonization $\mathrm{PrNi}_{0.5} \mathrm{Co}_{0.5} \mathrm{O}_{3-\delta}-\mathrm{Ce}_{0.9} \mathrm{Y}_{0.1} \mathrm{O}_{2-\delta}(\mathrm{PNC}-\mathrm{YDC}$ ) nanocomposites with a high mixed ionic-electronic conductivity are promising materials for such application. Their high oxygen mobility $\left(D_{O}\right.$ is up to $\sim 10^{-7} \mathrm{~cm}^{2} / \mathrm{s}$ at $700{ }^{\circ} \mathrm{C}$ ) is provided by a developed perovskite-fluorite interface and strong redistribution of $\operatorname{Pr}$ cations between phases [7,1012]. In thus formed $\mathrm{Ce}_{1-x-y} \mathrm{Pr}_{\mathrm{x}} \mathrm{Y}_{\mathrm{y}} \mathrm{O}_{2-\delta}$ domains fast oxygen migration occurs along ordered $\mathrm{Pr}^{3+/ 4+}$ chains due to ability of Pr cations to vary easily their charge $[7,11,13]$.

In our earlier work devoted to testing membranes based on PNC - YDC nanocomposite we demonstrated their high performance with the oxygen flux under air $/ \mathrm{CH}_{4}$ gradient $\sim 10 \mathrm{ml} \mathrm{O} / 2 \mathrm{~cm}^{2}$ min meeting criteria of the practical application [6,7]. A high $\mathrm{CH}_{4}$ conversion and syngas yield were shown with $\mathrm{H}_{2} / \mathrm{CO}$ ratio > 1 . In long-term tests a stable performance was demonstrated for at least $200 \mathrm{~h}$.

One of the ways of further improving membrane performance is deposition of the additional catalytic layer and using substrates with improved textural characteristics. This work aims at studying performance of membranes based upon novel $\mathrm{Ni} / \mathrm{Al}$ substrates and PNC - YDC nanocomposites with functionally graded catalytic layer.

\section{$2 \quad$ Materials and methods}

Individual nanocrystalline oxides $\operatorname{PrNi}_{0.5} \mathrm{Co}_{0.5} \mathrm{O}_{3-\delta} \quad(\mathrm{PNC}), \mathrm{Ce}_{0.9} \mathrm{Y}_{0.1} \mathrm{O}_{2-\delta} \quad(\mathrm{YDC})$, $\mathrm{Ce}_{0.9} \mathrm{Gd}_{0.1} \mathrm{O}_{2-\delta} \quad$ (GDC), $\quad \mathrm{MnFe}_{2} \mathrm{O}_{4} \quad(\mathrm{MF}), \quad \mathrm{Sm}_{0.15} \mathrm{Pr}_{0.15} \mathrm{Ce}_{0.35} \mathrm{Zr}_{0.3} \mathrm{O}_{2-\delta} \quad$ (SPCZ) and $\mathrm{Pr}_{0.2} \mathrm{Ce}_{0.4} \mathrm{Zr}_{0.4} \mathrm{O}_{2-\delta}$ (PCZ) were synthesized by modified complex polyester precursor (Pechini) route using water solutions of metal nitrates [14]. PNC - YDC and MF - GDC nanocomposites were obtained via ultrasonic dispersion of these powders in isopropanol in 1:1 weight ratio using T25 (ULTRA-TURRAX IKA, Germany) homogenizer. $\mathrm{Pt}\left(1.4\right.$ wt. \%)/SPCZ and $\mathrm{LaNi}_{0.9} \mathrm{Pt}_{0.1} \mathrm{O}_{3}$ (LNP) $/ \mathrm{PCZ} / \mathrm{Al}_{2} \mathrm{O}_{3}$ catalysts were prepared by wetness impregnation as described elsewhere [1,7].

Improved $\mathrm{Ni} / \mathrm{Al}$ foam substrates kindly provided by Powder Metallurgy Institute (Republic of Belarus) were used. A few PNC - YDC functional layers, MF - GDC buffer 
layer and Pt/SPCZ and LNP/PCZ/ $/{ }_{2} \mathrm{O}_{3}$ catalytic layers were consecutively deposed on the substrate and sintered at $1100{ }^{\circ} \mathrm{C}$ (for functional and buffer layers) or $900{ }^{\circ} \mathrm{C}$ (for catalytic layers) [7].

The membranes obtained were tested in $\mathrm{CH}_{4}$ selective oxidation into syngas using a specially built kinetic set-up $[1,5,8]$ and oven-placed double-flange reactor assembly at typical values of air and fuel feed rates $31 / \mathrm{h}$ and $7.6 \mathrm{l} / \mathrm{h}$ respectively. The temperature profile across the membrane with working diameter $25 \mathrm{~mm}$ was obtained by visible spectra pyrometry by shooting through the quartz window and analyzing RGB image as reported in our earlier work [7].

\section{$3 \quad$ Results and Discussion}

In contrary to our previous studies showing a certain non-uniformity of the membrane surface temperature [7], according to pyrometry measurements (Fig. 1) the temperature distribution during tests of the membrane is rather uniform. This demonstrates a good gas phase intermixing along the surface of the membrane providing absence of concentration and temperature gradients.

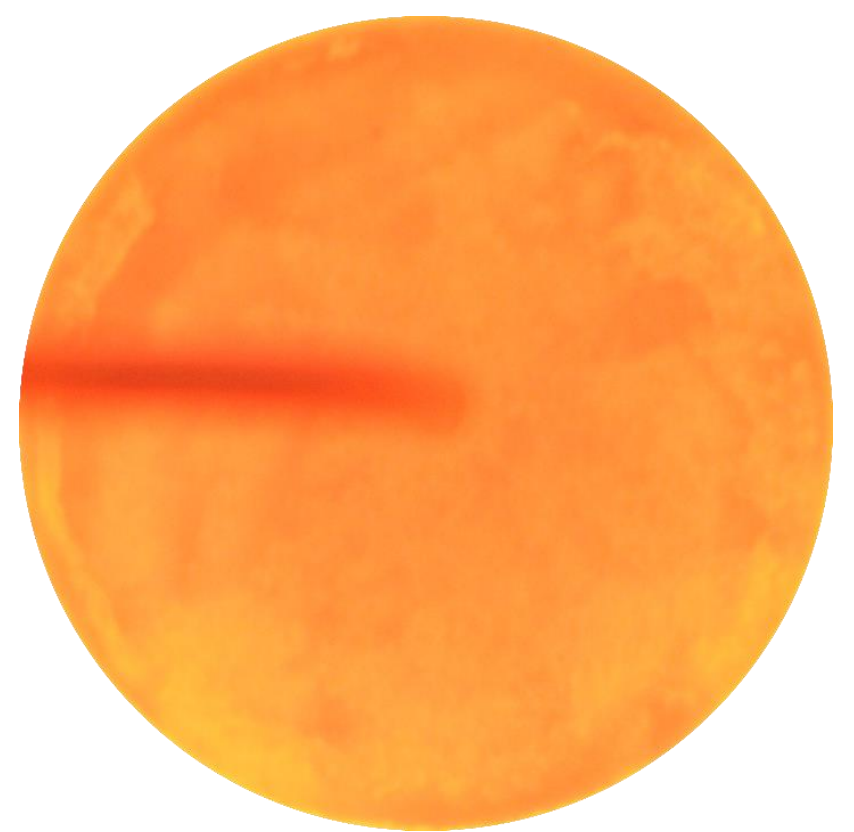

Figure 1. Image of the membrane tested at $916{ }^{\circ} \mathrm{C}$. 
$100 \quad 10^{\mathrm{TH}}$ International CONFERENCE ON Sustainable EnERgy and ENVIRONMENTAL Protection (June $27^{\mathrm{TH}}-30^{\mathrm{TH}}, 2017$, Bled, Slovenia), Hydrogen and Fuel Cells V. A. Sadykov, A. V. Krasnov, Y. E. Fedorova, A. I. Lukashevich, N. F. Eremeev, P. I. Skriabin, K. R. Valeev \& O. L. Smorygo: Novel Nanocomposite Materials for Oxygen Separation Membranes

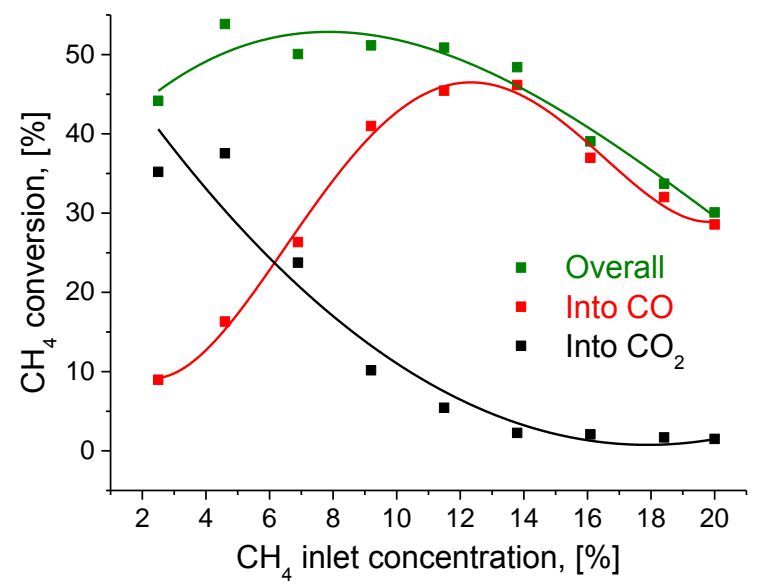

Figure 2. Dependence of methane conversion on its inlet concentration at $900{ }^{\circ} \mathrm{C}$.

For tests at $900{ }^{\circ} \mathrm{C}$, the methane conversion is $\sim 50 \%$ for its content in the feed up to 14 vol. \% decreasing at a higher $\mathrm{CH}_{4}$ content (Fig. 2). $\mathrm{CO}_{2}$ dominates in products up to $7 \% \mathrm{CH}_{4}$ in the feed, while in concentrated feeds the main product is $\mathrm{CO}$. These tendencies are explained by decreasing the coverage of the catalytic particles surface by reactive oxygen species transferred through membrane from the air side [7].

The selectivity of methane oxidation into syngas increases with the inlet methane concentration which is typical for the oxygen separation membranes. Syngas yield and methane conversion increase with temperature and contact time.

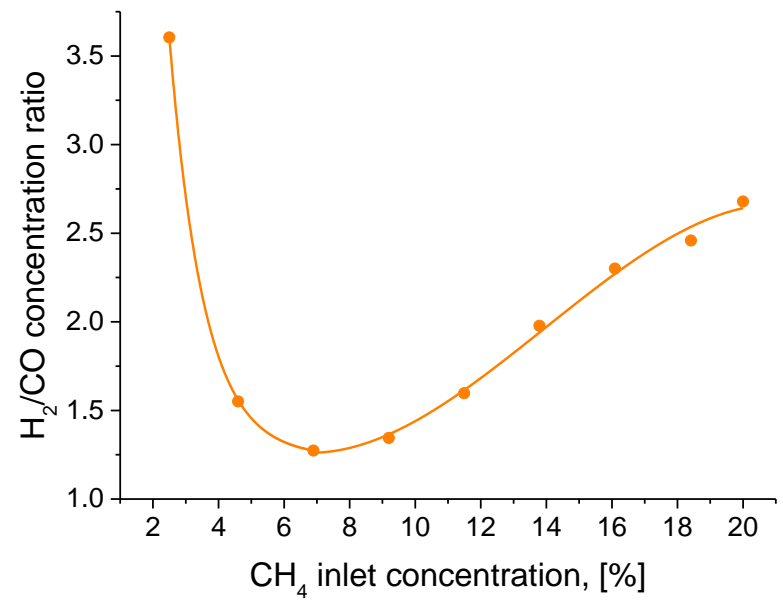

Figure $3 . \mathrm{H}_{2} / \mathrm{CO}$ ratio dependence on methane inlet concentration at $900{ }^{\circ} \mathrm{C}$. 
Carbonization of the membrane surface appears to be negligible or absent due to a high oxygen mobility of the functional layers $[7,11,12] . \mathrm{H}_{2} / \mathrm{CO}$ concentration ratio in the outlet gas mixture is $>1$, which is important for the practical application (Fig. 3). High $\mathrm{H}_{2} / \mathrm{CO}$ ratios for low $\mathrm{CH}_{4}$ inlet concentrations are explained by a low $\mathrm{CO}$ yield due to a high $\mathrm{CO}_{2}$ selectivity (Fig. 2). U-like shape of $\mathrm{H}_{2} / \mathrm{CO}$ concentration ratio curve in Fig. 3 is caused by almost linear increase of $\mathrm{H}_{2}$ content, while $\mathrm{CO}$ one reaches its peak value then decreases. $\mathrm{H}_{2} / \mathrm{CO}$ ratio reaches 2.7 in $\mathrm{CH}_{4}$ inlet concentration range where $\mathrm{CO}_{2}$ yield is negligible. $\mathrm{H}_{2}$ fraction in the outlet gas mixture reaches $25 \%$ at $900{ }^{\circ} \mathrm{C}$ due to a low water selectivity.

The addition of $\mathrm{CO}_{2}$ to the inlet gas mixture demonstrated stability to carbonization. However, $\mathrm{H}_{2} / \mathrm{CO}$ ratio decreases with increasing $\mathrm{CO}_{2}$ content in feed (Fig. 4) due to RWGS reaction. Small addition of $\mathrm{CO}_{2}$ even increases syngas yield especially for high $\mathrm{CH}_{4}$ inlet concentration (Figs. 5, 6). Also increase of syngas yield and decrease of $\mathrm{CO}_{2}$ content were observed in experiments with high feed rates (Fig. 6). Higher syngas yields were obtained at higher temperatures due to a higher oxygen flux through membrane.

Hence, performance characteristics of the membrane demonstrate that the materials used in its design are promising for the practical application.

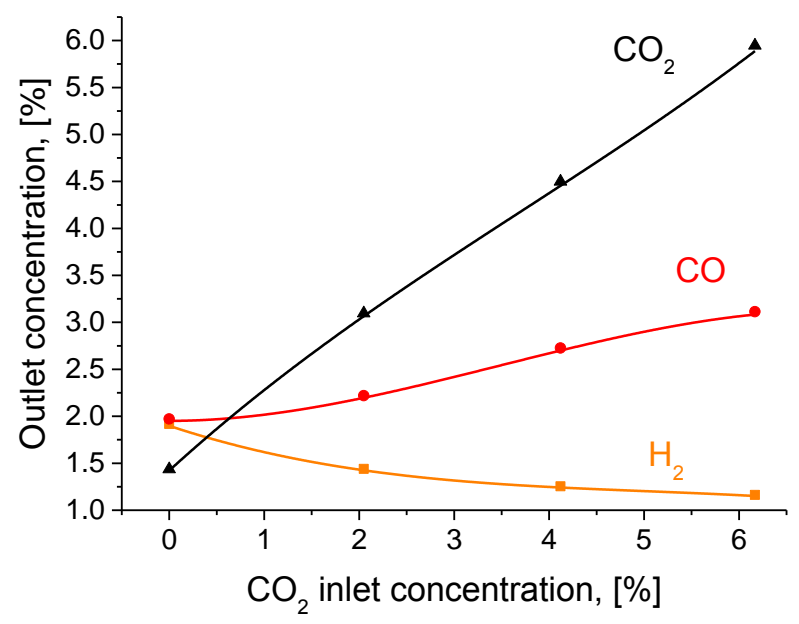

Figure 4. Dependence of methane conversion products at $900{ }^{\circ} \mathrm{C}$ and $\mathrm{CH}_{4}$ content $4.5 \%$ on carbon dioxide inlet content 
$10^{\text {TH }}$ International Conference on Sustainable Energy and Environmental Protection (June 27 $7^{\mathrm{TH}}-30^{\mathrm{TH}}, 2017$, Bled, Slovenia), Hydrogen ANd Fuel Cells

V. A. Sadykov, A. V. Krasnov, Y. E. Fedorova, A. I. Lukashevich, N. F. Eremeev, P. I. Skriabin, K. R. Valeev \& O. L. Smorygo: Novel Nanocomposite Materials for Oxygen Separation Membranes

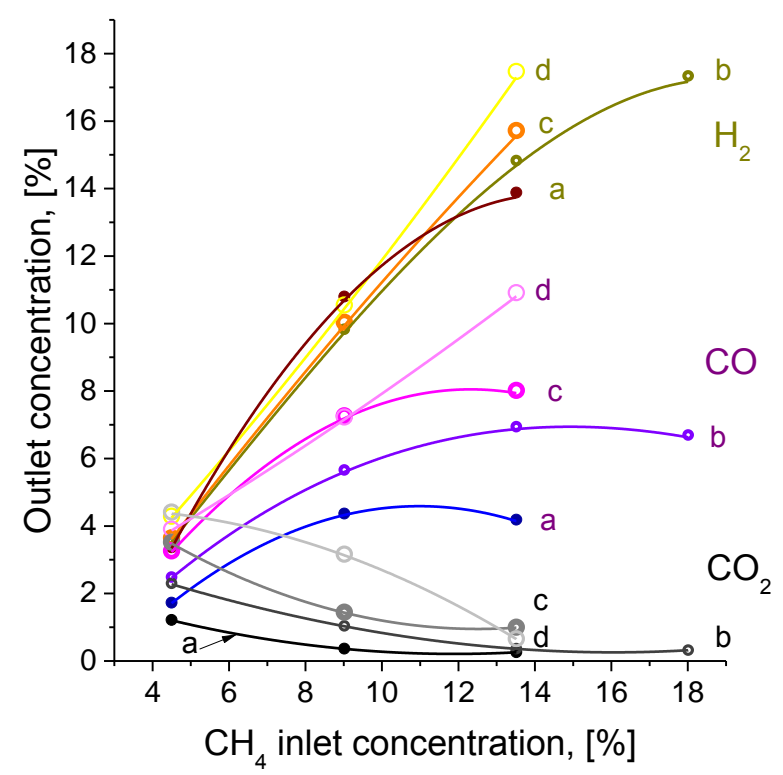

Figure 5. Dependence of methane conversion products on its inlet concentration at $900{ }^{\circ} \mathrm{C} . \mathrm{CO}_{2}$ inlet concentration is 0 (a), 0.84 (b), 1.63 (c) and $2.53 \%$ (d).

\section{4}

\section{Conclusions}

Successful test of the new membrane revealed stability of its components to carbonization. Almost uniform spatial distribution of the membrane surface temperature was achieved. A high yield of hydrogen-rich syngas was demonstrated. Thus, the materials involved are promising for the practical application as components of oxygen separation membranes. 
V. A. Sadykov, A. V. Krasnov, Y. E. Fedorova, A. I. Lukashevich, N. F. Eremeev, P. I.

Skriabin, K. R. Valeev \& O. L. Smorygo: Novel Nanocomposite Materials for Oxygen

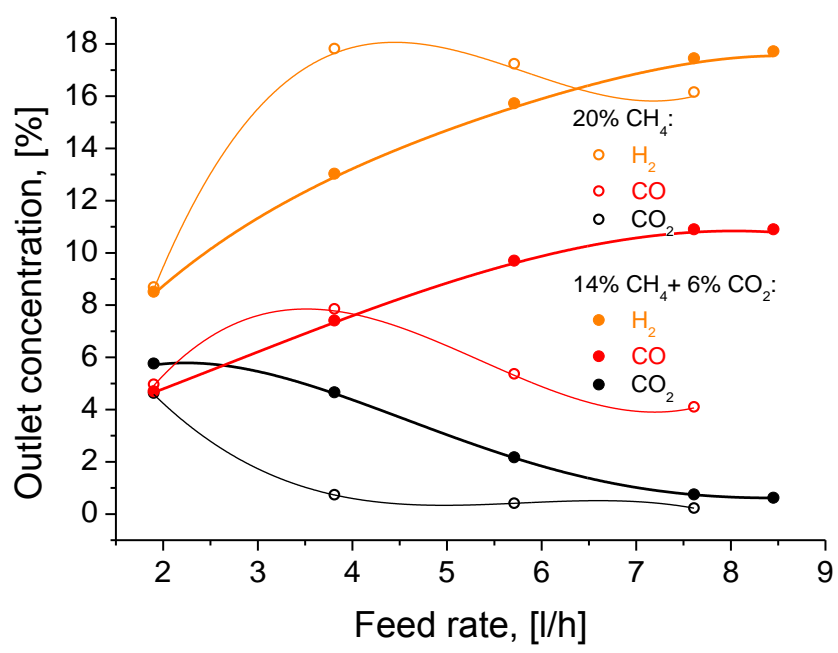

Figure 6. Dependence of methane conversion products on overall feed rate at $900{ }^{\circ} \mathrm{C}$

\section{Acknowledgements}

$\mathrm{Ni} / \mathrm{Al}$ foam substrates were kindly provided by Powder Metallurgy Institute (Republic of Belarus). Support by Russian Science Foundation (Project 16-13-00112) is gratefully acknowledged.

\section{References}

[1] V. Sadykov, A. Smirnova, A. Lukashevich, Z. Vostrikov, V. Rogov, T. Krieger, A. Ishchenko, V. Zaikovsky, L. Bobrova, J. Ross, O. Smorygo, A. Smirnova, B. Rietveld, and F. van Berkel, "Nanocomposite catalysts for steam reforming of methane and biofuels: Design and performance," in Advances in Nanocomposites - Synthesis, Characterization and Industrial Applications. Rijeka: InTech, 2011.pp. 909 - 946.

[2] Q. Zhang, T. Liu, Z. Zhu, L. Hao, and W. Liu, "Modeling of hydrogen permeation for Niceramic proton conductor composite membrane with symmetric structure," J. Memb. Sci., vol. 415 - 416, pp. 328 - 335, Oct. 2012.

[3] J. Vente, W. Haije, Z. Rak, "Performance of functional perovskite membranes for oxygen production," J. Memb. Sci., vol. 276, pp. 178 - 184, May 2006.

[4] M. L. Mottern, J. Y. Shi, K. Shqau, D. Yu, and H. Verweij, "Microstructural optimization of thin supported inorganic membranes for gas and water purification" in Advanced Membrane Technology and Applications. Hoboken: John Wiley \& Sons, Inc. pp. 899-928.

[5] V. Sadykov, V. Usoltsev, N. Yeremeev, N. Mezentseva, V. Pelipenko, T. Krieger, V. Belyaev, E. Sadovskaya, V. Muzykantov, Yu. Fedorova, A. Lukashevich, A. Ishchenko, A. Salanov, Yu. Okhlupin, N. Uvarov, O. Smorygo, A. Arzhannikov, M. Korobeynikov, and M. K. A. Thumm, "Functional nanoceramics for intermediate temperature solid oxide fuel cells and oxygen separation membranes," J. Eur. Ceram. Soc., vol. 33, pp. $2241-2250$, Oct. 2013. 
$10^{\mathrm{TH}}$ InTERNATIONAL CONFERENCE ON Sustainable ENERGy AND ENVIRONMENTAL Protection (June $27^{\mathrm{TH}}-30^{\mathrm{TH}}, 2017$, Bled, Slovenia), Hydrogen and Fuel Cells V. A. Sadykov, A. V. Krasnov, Y. E. Fedorova, A. I. Lukashevich, N. F. Eremeev, P. I. Skriabin, K. R. Valeev \& O. L. Smorygo: Novel Nanocomposite Materials for Oxygen Separation Membranes

[6] V. A. Sadykov, Yu. E. Fedorova, A. I. Lukashevich, Z. Yu. Vostrikov, N. F. Eremeev, A. V. Krasnov, P. I. Skryabin, and O. L. Smorygo, "Novel nanocomposite materials based on praseodymium nickelate-cobaltite for oxygen separation membranes," Mater. Today Proc. 2017 (in press).

[7] V. A. Sadykov, N. F. Eremeev, Z. S. Vinokurov, A. N. Shmakov, V. V. Kriventsov, A. I. Lukashevich, A. V. Krasnov, and A. V. Ishchenko, "Structural studies of Pr nickelatecobaltite - Y-doped ceria nanocomposite," J. Ceram. Sci. Technol., vol. 8, pp. 129 - 140, Jan. 2017.

[8] V. Sadykov, V. Zarubina, S. Pavlova, T. Krieger, G. Alikina, A. Lukashevich, V. Muzykantov, E. Sadovskaya, N. Mezentseva, and E. Zevak, "Design of asymmetric multilayer membranes based on mixed ionic-electronic conducting composites supported on Ni-Al foam substrate," Catal. Today, vol. 156, pp. 173 - 180, Oct. 2010.

[9] E. Shelepova, A. Vedyagin, V. Sadykov, N. Mezentseva, Yu. Fedorova, O. Smorygo, and I. Mishakov, "Syngas production in the catalytic membrane reactor: theoretical optimization of the process," presented at 12th International Conference on Catalysis in Membrane Reactors, Szczecin, 2015. p. 131.

[10] V. A. Sadykov, N. F. Eremeev, V. A. Bolotov, Yu. Yu. Tanashev, Yu. E. Fedorova, D. G. Amanbayeva, A. S. Bobin, E. M. Sadovskaya, V. S. Muzykantov, V. V. Pelipenko, A. I. Lukashevich, T. A. Krieger, A. V. Ishchenko, and A. L. Smirnova, "The effect of microwave sintering on stability and oxygen mobility of praseodymium nickelatescobaltites and their nanocomposites," Solid State Ionics, vol. 288, p. 76-81, May 2016.

[11] V. Sadykov, N. Eremeev, E. Sadovskaya, A. Bobin, A. Ishchenko, V. Pelipenko, V. Muzykantov, T. Krieger, and D. Amanbaeva, "Oxygen mobility and surface reactivity of $\mathrm{PrNi}_{1-\mathrm{x}} \mathrm{Co}_{\mathrm{x}} \mathrm{O}_{3-\delta}$ perovskites and their nanocomposites with $\mathrm{Ce}_{0.9} \mathrm{Y}_{0.1} \mathrm{O}_{2-\delta}$ by temperatureprogrammed isotope exchange experiments," Solid State Ionics, vol. 273, pp. 35 - 40, May 2015.

[12] V. Sadykov, N. Eremeev, G. Alikina, E. Sadovskaya, V. Muzykantov, V. Pelipenko, A. Bobin, T. Krieger, V. Belyaev, V. Ivanov, A. Ishchenko, V. Rogov, A. Ulihin, N. Uvarov, Yu. Okhlupin, J. Mertens, and I. Vinke, "Oxygen mobility and surface reactivity of $\mathrm{PrNi}_{1-\mathrm{x}} \mathrm{Co}_{\mathrm{x}} \mathrm{O}_{3+\delta}-\mathrm{Ce}_{0.9} \mathrm{Y}_{0.1} \mathrm{O}_{2-\delta}$ cathode nanocomposites," Solid State Ionics, vol. 262, pp. $707-712$, Sep. 2014.

[13] M. Y. Sinev, G. W. Graham, L. P. Haack, and M. Shelef, "Kinetic and structural studies of oxygen availability of the mixed oxides $\operatorname{Pr}_{1-x} \mathrm{M}_{\mathrm{x}} \mathrm{O}_{\mathrm{y}}(\mathrm{M}=\mathrm{Ce}, \mathrm{Zr})$," J. Mater. Res., vol. 11, pp. 1960 - 1971, Aug. 1996.

[14] V. A. Sadykov, S. N. Pavlova, T. S. Kharlamova, V. S. Muzykantov, N. F. Uvarov, Yu. S. Okhlupin, A. V. Ishchenko, A. S. Bobin, N. V. Mezentseva, G. M. Alikina, A. I. Lukashevich, T. A. Krieger, T. V. Larina, N. N. Bulgakov, V. M. Tapilin, V. D. Belyaev, E. M. Sadovskaya, A. I. Boronin, V. A. Sobyanin, O. F. Bobrenok, A. L. Smirnova, O. L. Smorygo, and J. A. Kilner, "Perovskites and their nanocomposites with fluorite-like oxides as materials for solid oxide fuel cells cathodes and oxygenconducting membranes: Mobility and reactivity of the surface/bulk oxygen as a key factor of their performance" in Perovskites: Structure, Properties and Uses. New York: Nova Science Publishers, 2010. pp. $67-178$. 
$10^{\mathrm{TH}}$ InTERnational CONFERENCE ON Sustainable ENERgy AND EnVironmental Protection (June $27^{\mathrm{TH}}-30^{\mathrm{TH}}$, 2017, Bled, Slovenia), Hydrogen ANd Fuel Cells

J. Krope, A.Ghani Olabi, D. Goričanec \& S. Božičnik

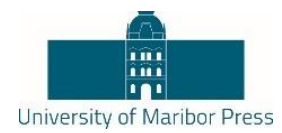

\title{
Electrochemical Resistance Reduction by Acid Treatment of Coal in Direct Carbon Fuel Cell
}

\author{
SeOngyong Eom, SeOngyool Ahn, Gyungmin Choi \& Duckjool Kim
}

\begin{abstract}
The surface properties of various types of carbonaceous fuels were changed by acid treatment, and raw fuels and treated fuels were evaluated to analyze acid effect with fuel types. Various types of carbon were modified by chemical treatment to compare electrochemical properties with different surface characteristics. Electrochemical parameters were compared with coal surface properties. For the correlation function of two characteristics, acid treatments of various carbon fuels were carried out considering the effect of the physical properties of solid fuels such as oxygen functional groups and ash on the surface. Three techniques were conducted to analyze the characteristic of fuel surface including thermogravimetric analysis, BET, and XPS. The correlation of physicochemical properties of coal and electrochemical resistance was discussed by means of open circuit voltage, maximum power density, and polarization resistance.
\end{abstract}

Keywords: • electrochemical resistance $\bullet$ acid treatment $\bullet$ surface oxygen groups $\bullet$ ash $\bullet$ reduction $\bullet$

CorResPondence AdDRESS: Seongyong Eom, Pusan National University, School of Mechanical Engineering, 2 Busandaehak-ro 63beon-gil, Jangjeon 2(i)-dong, Geumjeong-gu, 부산광역시 Busan, Korea: email: eom912@pusan.ac.kr. Seongyool Ahn, CRIEPI, School of Mechanical Engineering, T240-0101 Kanagawa Prefecture, Yokosuka, Nagasaka, 2 Chome-6 - 1 ,Japan; email: syahn405@gmail.com. Gyungmin Choi, Pusan National University, School of Mechanical Engineering, 2 Busandaehak-ro 63beon-gil, Jangjeon 2(i)-dong, Geumjeong-gu, 부산광역시 Busan, Korea: email: choigm@ pusan.ac.kr. Duckjool Kim, Pusan National University, School of Mechanical Engineering, 2 Busandaehak-ro 63beon-gil, Jangjeon 2(i)-dong, Geumjeong-gu, 부산광역시 Busan, Korea: email: djkim@pusan.ac.kr. 
$10^{\mathrm{TH}}$ International Conference on Sustainable EnERgy AND ENVIRONMENTAL Protection (June $27^{\mathrm{TH}}-30^{\mathrm{TH}}, 2017$, Bled, Slovenia), Hydrogen and Fuel Cells S. Eom, S. Ahn, G. Choi \& D. Kim: Electrochemical Resistance Reduction by Acid Treatment of Coal in Direct Carbon Fuel Cell

\section{Introduction}

In DCFC system using carbonaceous fuels, various fuel properties affect the electrochemical reaction. In previous study, the electrochemical characteristics on DCFC were evaluated by comparison of fuel properties using various solid carbon fuels. Following properties are major fuel properties which investigated the effect on DCFC performance such as volatile matters, surface composition, and ash.[1,2] In terms of the effect of the fuel properties, $\mathrm{Li}$ and co-workers investigated the properties that affect DCFC performance.[1] The effect of surface area, pore volume, and functional groups was investigated through correlation with performance. They also studied the effects of mineral matter in coal on cell performance and confirmed that $\mathrm{SiO}_{2}$ and $\mathrm{Al}_{2} \mathrm{O}_{3}$ decreased performance but $\mathrm{MgO}, \mathrm{CaO}$, and $\mathrm{Fe}_{2} \mathrm{O}_{3}$ enhance the electrochemical reaction.[3] Elleuch and co-workers also performed to determine correlation between fuel property and performance using wood charcoal.[4] The influence of carbon content, meso-macro porosity, disordered structure was discussed. In our previous research, we demonstrated that the surface oxygen concentration has an influence on DCFC performance.[5,6] In addition, we reported that coal volatilization is one of factor which affects cell performance due to high operating temperature. $[4,6]$

From previous researches, DCFC performances depend on the electrochemical oxidation reaction of carbonaceous fuel at anode side. In various fuel properties, the surface properties of the coal are especially important to form the triple phase boundary with the electrode and the molten electrolyte such as oxygen functional groups, surface pore, and ash. However, it was not identified exactly that what fuel properties have an influence what electrochemical resistances.

In this study, the objective was to perform experiment with the correlation between fuels surface properties and the inner resistances which are a charge transfer resistance and electrolyte resistance. To demonstrate the relationship between surface properties and oxygen functional groups, we carried on acid treatment using hydrochloric acid $(\mathrm{HCl})$ and nitric acid $\left(\mathrm{HNO}_{3}\right)$ to change coal surface characteristic. Glencore coal that is bituminous coal and Adaro coal that is sub-bituminous coal

Table 1. Proximate and ultimate analysis of raw coals (wt \%, dry basis)

\begin{tabular}{|c|c|c|c|c|c|c|c|c|}
\hline \multirow{2}{*}{ Fuel } & \multicolumn{3}{|c|}{ Proximate analysis } & \multicolumn{5}{c|}{ Ultimate analysis } \\
\cline { 2 - 9 } & VM & FC & Ash & C & H & O & N & S \\
\hline Bituminous coal(Glencore) & 37.18 & 53.66 & 9.16 & 72.20 & 4.61 & 10.94 & 2.35 & 0.74 \\
\hline Sub-bituminous coal (Adaro) & 47.99 & 50.20 & 1.80 & 71.20 & 5.27 & 18.93 & 1.28 & 0.03 \\
\hline
\end{tabular}

were selected and modified by $\mathrm{HCl}$ and $\mathrm{HNO}_{3}$. The electrochemical reaction parameter of raw coal and treated coal were compared with coal surface properties to investigate correlation. To measure reaction parameter, the half-cell consists of three electrodes, and the current density, power density, and electrochemical impedance were discussed. 
$10^{\mathrm{TH}}$ INTERNATIONAL CONFERENCE ON SUSTAINABLE ENERGY AND ENVIRONMENTAL Protection (June $27^{\mathrm{TH}}-30^{\mathrm{TH}}, 2017$, Bled, Slovenia), ENERGy Storage

S. Eom, S. Ahn, G. Choi \& D. Kim: Electrochemical Resistance Reduction by Acid Treatment of Coal in Direct Carbon Fuel Cell

\section{Experimental}

\subsection{Fuel treatment}

The bituminous coal which contains low volatile and high ash component and the subbituminous coal which contains high volatile and low ash component were used for evaluation of surface characteristic. Raw coals were performed by proximate analysis and ultimate analysis and these results were shown in Table 1 . The coals were grinded and sieved $0.09-0.15 \mathrm{~mm}$ of size. The 4 mole of solvents were made by mixing acid solution and deionized water. $\mathrm{HCl}$ and $\mathrm{HNO}_{3}$ are $38 \%$ of assay and $62 \%$ of assay, respectively. Raw coals were immersed in acid solution for 24 hours. After that, treated samples were washed by distilled water and it was dried at $80^{\circ} \mathrm{C}$ during 24 hours.

\subsection{Analysis method of fuel properties}

Three techniques were employed to account for electrochemical reactions of two types of coals and treated coals in the DCFC system. The thermal reactivity of fuels has been investigated through thermogravimetric analysis (TGA) using SDT-Q600 (TA instrument, USA) under Argon gas atmosphere because the anode side is filled with Argon to prevent coal combustion. Therefore, thermal characteristics of fuels in the Argon are important and accomplished. The flow rate of atmospheric gas was set to 100 $\mathrm{ml} / \mathrm{min}$ and ambient temperature was heated from room temperature to $900^{\circ} \mathrm{C}$ with heating rate of $10^{\circ} \mathrm{C} / \mathrm{min}$.

The surface characteristic of raw coal and treated coal were demonstrated by the gas adsorption. The specific surface area and pore volume of the solid fuels were estimated using an ASAP 2020 (Miciomeritics Co., USA) instrument. Adsorptive gas is nitrogen gas and $0.5 \mathrm{~g}$ of the sample was used in each analysis. The adsorption temperature was kept constant at $-196.15^{\circ} \mathrm{C}$ using liquid nitrogen. Adsorption experiments were carried out in the relative pressure range of $0.0-0.99$. Using the relative pressure range of 0.0 0.3 , the specific surface area was determined.

X-ray photoelectron spectroscopy (XPS) examination was carried out with Theta Probe AR-XPS System (Thermo Fisher Scientific, U.K.). The ESCALAB250 XPS system used the monochromatic $\mathrm{Al} \mathrm{K} \alpha$ radiation $(\mathrm{hv}=1486.6 \mathrm{eV})$ as an $\mathrm{X}$-ray source which was operated at $15 \mathrm{kV}$ and $150 \mathrm{~W}$ power source and the spot size was $400 \mu \mathrm{m}$. The pass energy kept constant of $50 \mathrm{eV}$ while data was acquired for 201 times with $0.1 \mathrm{eV}$ energy step size. 
$10^{\mathrm{TH}}$ International Conference on Sustainable Energy and Environmental Protection (June $27^{\mathrm{TH}}-30^{\mathrm{TH}}, 2017$, Bled, Slovenia), Hydrogen and Fuel Cells S. Eom, S. Ahn, G. Choi \& D. Kim: Electrochemical Resistance Reduction by Acid Treatment of Coal in Direct Carbon Fuel Cell

\subsection{Half-cell system}

The direct carbon fuel cell (DCFC) based on molten carbonate fuel cell operated using two types of coals and treated coals. Figure 1 shows the DCFC apparatus to use molten carbonate

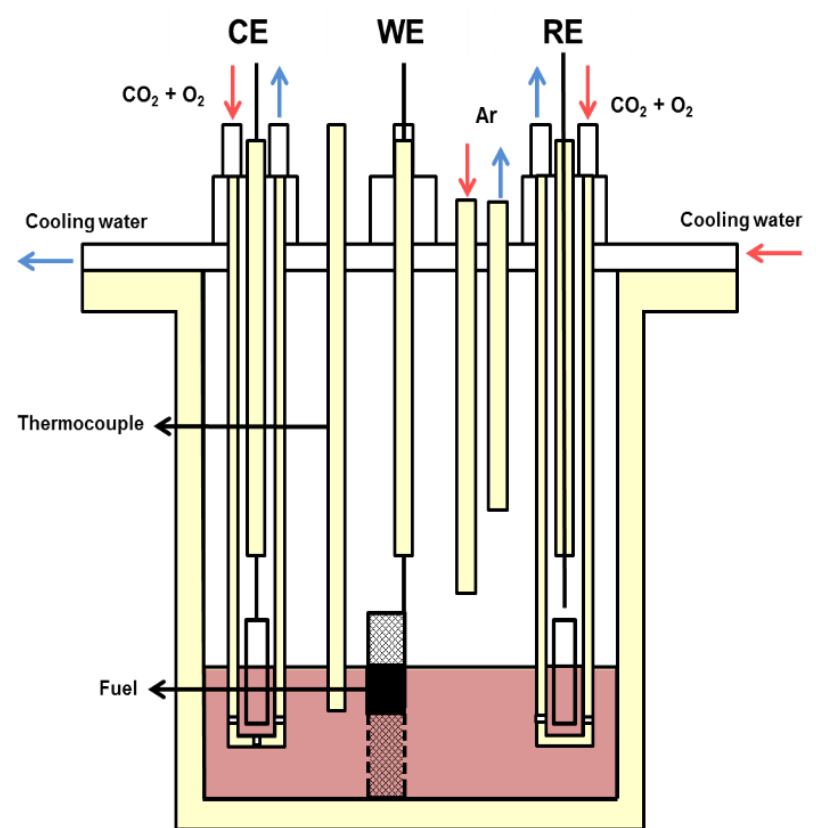

Figure 1. Schematic diagram of DCFC system

electrolyte.[5,6] The lithium carbonate, purity of $99.0 \%$, and potassium carbonate, purity of $99.8 \%$, were used as electrolyte (Junsei, Japan).

The two carbonate were mixed with 62:38 mole ratios of $\mathrm{Li}_{2} \mathrm{CO}_{3}$ and $\mathrm{K}_{2} \mathrm{CO}_{3}$ which have the lowest melting temperature. For each condition, the fuels were loaded $1.5 \mathrm{~g}$. The working electrode (anode), the counter electrode (cathode), and the reference electrode were made of $\mathrm{Ag}$ and a cylindrical working electrode was inner-diameter of $15 \mathrm{~mm}$ and length of $50 \mathrm{~mm}$ (effective surface area $3.64 \mathrm{~cm}^{2}$ ). The current and voltage of fuels was measured by electrochemical measurement with a Versastat3 (Princeton Applied Research). Using linear sweep potentiometry method, the current density was obtained from open circuit voltage $(\mathrm{OCV})$ to $0 \mathrm{~V}$ as scan rate of $1 \mathrm{mV} / \mathrm{s}$.[7] The electrochemical characteristics were demonstrated by current density-potential (i-V), current densitypower density (i-p), and Nyquist plot of impedance. The impedances were measured from $0.1 \mathrm{~Hz}$ to $100 \mathrm{kHz}$. The voltage amplitude of frequency was $10 \mathrm{mV}$. The $\mathrm{i}-\mathrm{V}$ and impedance tests were performed at 1000 s intervals. 
$10^{\mathrm{TH}}$ INTERNATIONAL CONFERENCE ON SUSTAINABLE ENERGY AND ENVIRONMENTAL Protection (June $27^{\mathrm{TH}}-30^{\mathrm{TH}}, 2017$, Bled, SLovenia), EnERgy Storage

S. Eom, S. Ahn, G. Choi \& D. Kim: Electrochemical Resistance Reduction by Acid Treatment of Coal in Direct Carbon Fuel Cell

\section{$3 \quad$ Results and Discussion}

\subsection{Characteristic of thermal reactivity}

Table 2. The surface texture of fuels measured by gas adsorption

\begin{tabular}{|c|c|c|c|}
\hline Fuel & $\begin{array}{c}\text { Surface area } \\
\left(\mathrm{m}^{2} / \mathrm{g}\right)\end{array}$ & $\begin{array}{c}\text { Pore volume } \\
\left(\mathrm{cm}^{3} / \mathrm{g}\right)\end{array}$ & $\begin{array}{c}\text { Mean } \\
\text { diameter of } \\
\text { pores }(\mathrm{nm})\end{array}$ \\
\hline $\begin{array}{c}\text { Glencore } \\
\text { coal }\end{array}$ & 12.15 & $5.99 \times 10^{-3}$ & 1.975 \\
\hline $\begin{array}{c}\text { Glencore } \\
\mathrm{HCl}\end{array}$ & 2.409 & $1.18 \times 10^{-3}$ & 1.959 \\
\hline $\begin{array}{c}\text { Glencore } \\
\mathrm{HNO}_{3}\end{array}$ & 1.872 & $0.92 \times 10^{-3}$ & 1.964 \\
\hline Adaro coal & 3.340 & $1.61 \times 10^{-3}$ & 1.934 \\
\hline Adaro $\mathrm{HCl}$ & 2.756 & $1.34 \times 10^{-3}$ & 1.943 \\
\hline Adaro $\mathrm{HNO}_{3}$ & 1.374 & $0.63 \times 10^{-3}$ & 1.825 \\
\hline
\end{tabular}

In DCFC system, the properties change of using fuel occurs in the inert gas atmosphere because operating temperature is over decomposition temperature of volatile matter.[6] Through the weight variation, the thermal reactivity of fuels was measured. Figure 2 and 3 showed results of thermal decomposition of raw coal and acid treated coals. In all fuels, a slight weight change

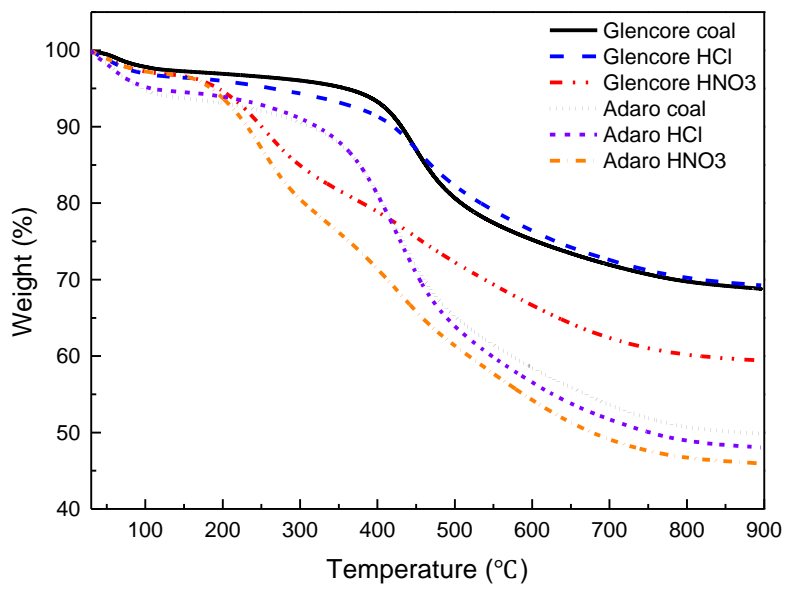

Figure 2. TG curves of raw coals and treated coals 
$11010^{\mathrm{TH}}$ International Conference On Sustainable EnERgy and Environmental Protection (June $27^{\mathrm{TH}}-30^{\mathrm{TH}}, 2017$, Bled, Slovenia), Hydrogen and Fuel Cells S. Eom, S. Ahn, G. Choi \& D. Kim: Electrochemical Resistance Reduction by Acid Treatment of Coal in Direct Carbon Fuel Cell

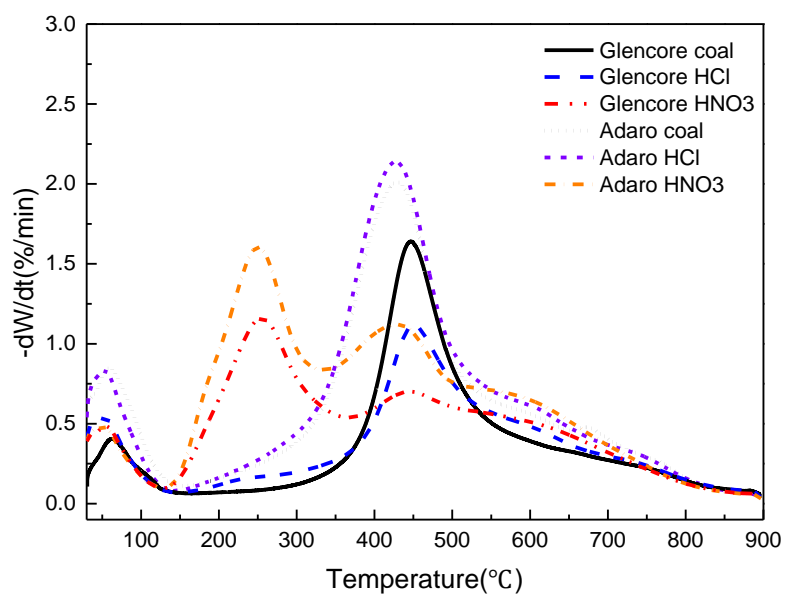

Figure 3. DTG curves of raw coals and treated coals

could be confirmed near $100^{\circ} \mathrm{C}$ due to evaporation of water. A rapid weight change of raw coals and those of $\mathrm{HCl}$ treated coals showed similar trend that Adaro coal and Glencore coal were decomposed about $300^{\circ} \mathrm{C}$ and $350^{\circ} \mathrm{C}$, respectively. However, in cases of $\mathrm{HNO}_{3}$ treated coals, the weight change of thermal decomposition was observed from $150^{\circ} \mathrm{C}$. In Figure 2, when comparing the TG profiles of fuels, $\mathrm{HNO}_{3}$ treated coals shows the highest decomposition reaction. As a result, $\mathrm{HNO}_{3}$ treated coals have large reactivity than $\mathrm{HCl}$ treated coal. It means that fuel properties change by acid treatment lead to high reactivity of solid fuels.

\subsection{Characteristic of surface textual}

To analyze the fuel surface properties, the gas adsorption was performed and these results were shown as Table 2. From this analysis, we obtained the specific surface area, total pore volume and mean pore diameter. At the results of Table 2, the specific surface area was reduced after the acid treatment process. In this regard, Li et al. investigated that effects of the acid treatment on specific surface area using activated carbon and conformed that the specific surface area was decreased after $\mathrm{HCl}$ and $\mathrm{HNO}_{3}$ treatment.[8] $\mathrm{HNO}_{3}$ treated carbon decrease more the specific surface area than the $\mathrm{HCl}$ treated coal. The pore walls on fuel surface collapsed during acid treatment progress and the specific surface area and the pore volume was decreased.[8,9]

\subsection{Oxygen concentration and ash components on fuel surface}

To investigate the variation of atomic concentrations caused by the acid treatment, the surface composition was shown in Table 3. By XPS measurement, the oxygen on fuel surface and the ash component were obtained. In the $\mathrm{HNO}_{3}$ treatment, the oxygen concentration of Glencore coal and Adaro coal increased $0.9 \%$ and $4.6 \%$, respectively. The $\mathrm{HNO}_{3}$ treated coals show the higher oxygen content than raw coals. However, $\mathrm{HCl}$ 
$10^{\text {TH }}$ INTERNATIONAL CONFERENCE ON SUSTAINABLE ENERGY AND ENVIRONMENTAL Protection (June $27^{\mathrm{TH}}-30^{\mathrm{TH}}, 2017$, Bled, Slovenia), EnERgy Storage

S. Eom, S. Ahn, G. Choi \& D. Kim: Electrochemical Resistance Reduction by Acid Treatment of Coal in Direct Carbon Fuel Cell

treated coal of Glencore coal has the lowest surface oxygen content in contrast with $\mathrm{HCl}$ treated coal of Adaro coal. Compared to the previous studies that treated carbon fuels show an increase in the surface oxygen content as expected, the oxygen concentration trend of Glencore coal by acid treatment is the opposite.[8] When the coal was treated by $\mathrm{HCl}$, the reduction of oxygen amount is the removal of chemisorption moisture and ash components which is present as an oxide in coal. The silicon and aluminium which are major coal ash exist in a form of $\mathrm{SiO}_{2}$ and $\mathrm{Al}_{2} \mathrm{O}_{3}$. Therefore, oxygen concentrations of XPS contain this component. Through the ratio of ash to carbon of $\mathrm{HCl}$-treated coal was $25.96 \%$ and that of $\mathrm{HNO}_{3}$ treated coal was $30.78 \%, \mathrm{HCl}$ treated coal has the lowest ash contents; especially Si2p. After oxygen contents of coal ash were eliminated, the ratio tendency of oxygen to carbon was changed as followed. Glencore coal is $15.72 \%$, Glencore $\mathrm{HCl}$ is $16.54 \%$, and Glencore $\mathrm{HNO}_{3}$ is $19.75 \%$. As these results, $\mathrm{HCl}$ and $\mathrm{HNO}_{3}$ treatment increase oxygen concentration on fuel surface, $\mathrm{HNO}_{3}$ treated coals are larger than raw coals and $\mathrm{HCl}$ treated coals.

Table 3. Surface composition of carbonaceous fuels measured by XPS

\begin{tabular}{|c|c|c|c|c|c|c|}
\hline Fuel & $\mathrm{C}($ at.\%) & $\mathrm{O}($ at.\%) & $\mathrm{Si}($ at.\%) & $\mathrm{Al}($ at.\%) & $\mathrm{O} / \mathrm{C}(\%)$ & $(\mathrm{Si}+\mathrm{Al}) / \mathrm{C}(\%)$ \\
\hline Glencore coal & 46.20 & 34.80 & 10.08 & 7.00 & 75.32 & 36.97 \\
\hline Glencore $\mathrm{HCl}$ & 54.94 & 30.80 & 7.93 & 6.33 & 56.21 & 25.96 \\
\hline Glencore $\mathrm{HNO}_{3}$ & 48.44 & 35.66 & 9.76 & 6.15 & 76.79 & 30.78 \\
\hline Adaro coal & 85.03 & 14.97 & - & - & 17.61 & - \\
\hline Adaro $\mathrm{HCl}$ & 82.42 & 17.58 & - & - & 21.33 & - \\
\hline Adaro $\mathrm{HNO}_{3}$ & 80.50 & 19.50 & - & - & 24.22 & - \\
\hline
\end{tabular}

\subsection{Concentration of surface oxygen functional groups}

The surface functional groups which consist of carbon and oxygen exist in various types as shown in Table 4.[10,11] The different functional groups have a unique binding energy, which causes different dissociation temperature and reaction rate of each functional group. Therefore, the traditional relationship between the $\mathrm{O} / \mathrm{C}$ ratio and the DCFC performance is less accurate. In order to investigate the exact correlation of oxygen functional group and the electrochemical reaction, the oxygens on fuel surface must be distinguished as each oxygen functional group. Using the O1s Spectrum which was obtained by XPS, the oxygen concentrations with oxygen functional groups were calculated and shown in Table 4. A sum of Lorentzian-Gaussian functions is used for deconvolution of XPS spectra of O1s, which can determine the quantitative amount of oxygen functional groups on fuel surface.[12,13] The peaks were set as the full width at half maximum equal to $2.0 \mathrm{eV}$ and allowing the position of the peak center to vary within $\pm 0.2 \mathrm{eV}$ of the reported value.[10] The functionalities contribute with peaks located at these five binding energies; $531.1 \mathrm{eV}, 532.3 \mathrm{eV}, 533.3 \mathrm{eV}$, and $534.2 \mathrm{eV}$. The $\mathrm{HNO}_{3}$ treatment which mean carbonyl groups, while the $533.3 \mathrm{eV}$ and $534.2 \mathrm{eV}$ of binding energy, such as ether oxygen and carboxylic acids, were decreased. This result was good agreement with Figueiredo 
112 10 $10^{\mathrm{TH}}$ International Conference On Sustainable EnERgy and Environmental Protection (June $27^{\mathrm{TH}}-30^{\mathrm{TH}}, 2017$, Bled, Slovenia), Hydrogen and Fuel Cells S. Eom, S. Ahn, G. Choi \& D. Kim: Electrochemical Resistance Reduction by Acid Treatment of Coal in Direct Carbon Fuel Cell

Table 4. Oxygen Functional Groups on Fuel Surface

\begin{tabular}{|c|c|c|c|c|c|c|c|c|}
\hline \multirow{2}{*}{$\begin{array}{c}\text { Binding } \\
\text { energy } \\
(\mathrm{eV})\end{array}$} & \multicolumn{3}{|c|}{ Glencore coal } & \multicolumn{3}{|c|}{ Adaro coal } & \multirow{2}{*}{$\begin{array}{l}\text { Surface functional } \\
\text { groups }\end{array}$} & \multirow{2}{*}{$\begin{array}{l}\text { Decomposition } \\
\text { Temperature }\end{array}$} \\
\hline & $\begin{array}{l}\text { Raw } \\
\text { coal }\end{array}$ & $\mathrm{HCl}$ & $\mathrm{HNO}_{3}$ & $\begin{array}{l}\text { Raw } \\
\text { coal }\end{array}$ & $\mathrm{HCl}$ & $\mathrm{HNO}_{3}$ & & \\
\hline 531.1 & 3.00 & 4.76 & 6.11 & 3.82 & 5.33 & 4.85 & $\begin{array}{l}-\mathrm{C}=\mathrm{O} \text { in carbonyl and } \\
\text { quinone }\end{array}$ & $-700-980^{\circ} \mathrm{C}$ \\
\hline 532.3 & 6.05 & 7.82 & 10.64 & 5.31 & 5.61 & 7.98 & $\begin{array}{l}\text { - Carbonyl in lactone } \\
\text { and anhydrides } \\
\text { - Oxygen atoms in } \\
\text { phenol } \\
\text { - Ethers }\end{array}$ & $\begin{array}{l}-400-630^{\circ} \mathrm{C} \\
-600-700^{\circ} \mathrm{C} \\
-700^{\circ} \mathrm{C}\end{array}$ \\
\hline 533.3 & 2.56 & 3.03 & 1.37 & 4.92 & 4.85 & 5.82 & $\begin{array}{l}\text { - Ether oxygen in } \\
\text { lactone and anhydrides }\end{array}$ & $-400-630^{\circ} \mathrm{C}$ \\
\hline 534.2 & 3.40 & 0.93 & 1.62 & 0.92 & 1.79 & 0.85 & - Carboxylic acids & $-100-400^{\circ} \mathrm{C}$ \\
\hline Total O & 15.72 & 16.54 & 19.75 & 14.97 & 17.58 & 19.51 & & \\
\hline
\end{tabular}

et al. studies that the double bond of carbon and oxygen on fuel surface was increased through $\mathrm{HNO}_{3}$ acid treatment.[10] All treated coal were increased with the double bond of carbon and oxygen in carbonyl and quinone groups $(533.3 \mathrm{eV})$. In case of $\mathrm{HCl}$ treatment, Glencore $\mathrm{HCl}$ was added with lactone and anhydrides groups $(532.3 \mathrm{eV}$ and $533.3 \mathrm{eV}$ ) and Adaro $\mathrm{HCl}$ was added with carboxylic acids. In Figure 2, the weight variations which were reduced from $100^{\circ} \mathrm{C}$ were caused by carboxylic acid groups through the decomposition temperature in Table 4 . The acid treated coals tended to increase the weight reduction at about $400^{\circ} \mathrm{C}$ because of the additional the lactone group and anhydrides group. The acid treatments formed the oxygen functional groups on fuel surface which is decomposition temperature over operating temperature $(531.1 \mathrm{eV}$ and $532.3 \mathrm{eV}$ ), while the proportion of the carboxylic acids in the whole oxygen groups was decreased except Adaro $\mathrm{HCl}$. Through the characteristic of each oxygen functional group, the carbonyl, quinone, phenol groups may have an influence on electrochemical reaction parameter.

\subsection{Electrochemical characteristics of raw coals and treated coals}

To examine the electrochemical reaction characteristics of each fuel, a half-cell experiment was conducted at $650^{\circ} \mathrm{C}$. When the open circuit voltage was kept constant, the linear sweep voltammetry was measured as $1 \mathrm{mV} / \mathrm{s}$ of scan rate.[2] The i-V and i-p curves of carbon fuels were shown in Figure 4 and 5. Two figures indicate the features of the electrochemical reactions of raw coals and treated coals. The OCV of treated coals are higher than raw coal because of the produced gases from additional oxygen functional groups.[14] In Glencore coal, the maximum power densities of each fuel were 39.20 $\mathrm{mW} / \mathrm{cm}^{2}$ for $\mathrm{HNO}_{3}$ treated coal, $29.80 \mathrm{~mW} / \mathrm{cm}^{2}$ for $\mathrm{HCl}$ treated coal, and $22.68 \mathrm{~mW} / \mathrm{cm}^{2}$ for raw coal, respectively. In case of $\mathrm{HNO}_{3}$ treated coal, the maximum power density improved $73 \%$ compared to those of raw coal. The maximum power density of $\mathrm{HCl}$ 
$10^{\mathrm{TH}}$ INTERNATIONAL CONFERENCE ON SUSTAINABLE ENERGY AND ENVIRONMENTAL Protection (June $27^{\mathrm{TH}}-30^{\mathrm{TH}}, 2017$, Bled, SLovenia), EnERgy Storage

S. Eom, S. Ahn, G. Choi \& D. Kim: Electrochemical Resistance Reduction by Acid

Treatment of Coal in Direct Carbon Fuel Cell

treated coal improved $31 \%$ for raw coal. In Adaro coal, the maximum power densities of each fuel were $28.24 \mathrm{~mW} / \mathrm{cm}^{2}$ for $\mathrm{HNO}_{3}$ treated coal, $23.65 \mathrm{~mW} / \mathrm{cm}^{2}$ for $\mathrm{HCl}$ treated coal, and $19.96 \mathrm{~mW} / \mathrm{cm}^{2}$ for raw coal, respectively. In case of $\mathrm{HNO}_{3}$ treated coal, the maximum power density improved $41 \%$ compared to those of raw coal. The maximum power density of $\mathrm{HCl}$ treated coal improved $18 \%$ for raw coal. This is good agreement with previous research that $\mathrm{HNO}_{3}$ treatment showed the highest performance than other treatment using activated carbon and carbon black.[8] Increasing oxygen functional groups improve the wettability between solid carbon fuels and electrolyte and increase the reaction area.[15] Further, according to previous study, the presence of surface oxygens improves the oxidation reaction rate of carbon. $[1,8]$

In Table 2, raw coals showed the highest surface area and the decrease of surface area was caused

Table 5. Electrochemical resistance for each fuels $(\Omega)$

\begin{tabular}{|c|c|c|}
\hline Fuel & $\begin{array}{c}\text { Electrolysis } \\
\text { resistance }\end{array}$ & $\begin{array}{c}\text { Charge transfer } \\
\text { resistance }\end{array}$ \\
\hline Glencore coal & 0.228 & 7.682 \\
\hline Glencore $\mathrm{HCl}$ & 0.217 & 4.677 \\
\hline Glencore $\mathrm{HNO}_{3}$ & 0.237 & 3.934 \\
\hline Adaro coal & 0.373 & 8.035 \\
\hline Adaro $\mathrm{HCl}$ & 0.352 & 5.756 \\
\hline Adaro $\mathrm{HNO}_{3}$ & 0.311 & 5.401 \\
\hline
\end{tabular}


$11410^{\mathrm{TH}}$ International CONFERENCE ON Sustainable ENERGY AND ENVIRONMENTAL Protection (June $27^{\mathrm{TH}}-30^{\mathrm{TH}}, 2017$, Bled, Slovenia), Hydrogen ANd Fuel Cells

S. Eom, S. Ahn, G. Choi \& D. Kim: Electrochemical Resistance Reduction by Acid Treatment of Coal in Direct Carbon Fuel Cell

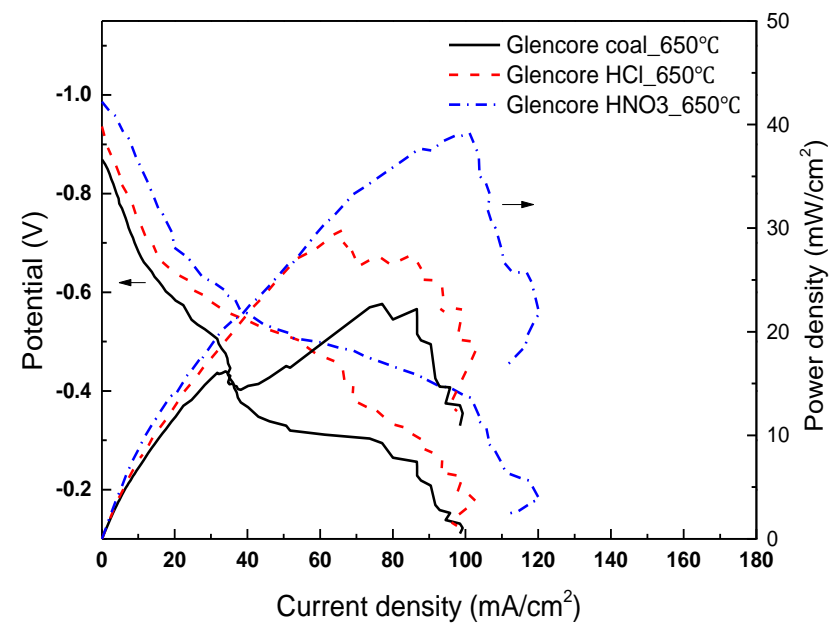

Figure 4. i-V and i-p curve of Glencore coal and treated coal at $650^{\circ} \mathrm{C}$

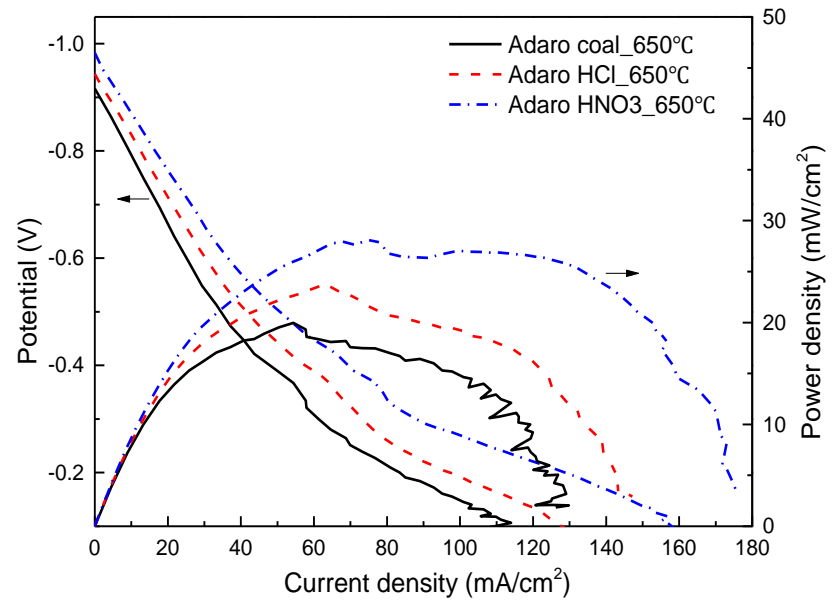

Figure 5. i-V and i-p curve of Adaro coal and treated coal at $650^{\circ} \mathrm{C}$

by $\mathrm{HNO}_{3}$ and $\mathrm{HCl}$ treatment. However, treated coals improved performance even though specific surface area was decreased because coals are non-porous material and most porous sizes are nano-scales. The mean pore diameters from gas adsorption results were about $2 \mathrm{~nm}$ and the solid carbon fuels had less pore volume compared to other porous carbons. Therefore, when comparing performance surface area, it is considered effective surface area that the electrochemical reactions occurred. In these results, the surface oxygen functional groups were significantly related to the actual electrochemical reaction unlike the surface area.

To obtain the charge transfer resistances and electrolyte resistance of the electrochemical reaction, the electrochemical impedance was measured at the open-circuit voltage. The 
$10^{\text {TH }}$ INTERNATIONAL CONFERENCE ON SUSTAINABLE ENERGY AND ENVIRONMENTAL Protection (June 27 $7^{\mathrm{TH}}-30^{\mathrm{TH}}, 2017$, Bled, Slovenia), ENERgy Storage

S. Eom, S. Ahn, G. Choi \& D. Kim: Electrochemical Resistance Reduction by Acid

Treatment of Coal in Direct Carbon Fuel Cell

results are shown in Table 5. The charge transfer resistance of $\mathrm{HNO}_{3}$ treated coals, which has the highest oxygen concentration, were smaller than those of other fuels because $\mathrm{HNO}_{3}$ treated coal has a higher reactivity than other fuels. In Table 4, the charge transfer resistance had a linear relationship with the oxygen components corresponding to 531.1 $\mathrm{eV}$ and $532.3 \mathrm{eV}$. The carbonyl, quinone, and phenol groups were mainly considered because the ether oxygen in lactone and anhydrides and carboxylic acid decompose at a low temperature.

\section{$4 \quad$ Conclusions}

In the cases of $\mathrm{HCl}$ treated coal and $\mathrm{HNO} 3$ treated coal, they showed similar polarization curve of raw coal in the whole current density region. However, the $\mathrm{OCV}$ of $\mathrm{HNO}_{3}$ treated coal was higher than other fuels. $\mathrm{HCl}$-treated coal and $\mathrm{HNO}_{3}$ treated coal were improved $6.1 \%$ and $30.5 \%$ compared to the maximum power density of raw coal because of changing coal properties caused by acid treatment. $\mathrm{HCl}$, non-oxidant acid, removes the mineral component. By comparison, $\mathrm{HNO}_{3}$, oxidant acid, change the surface composition and surface functional groups.

1) Through the maximum power density, both acid treatments increased the cell performance (raw coal $<\mathrm{HCl}$ treated coal $<\mathrm{HNO}_{3}$ treated coal).

2) The surface area and pore volume of fuels were less influence on DCFC performance because the solid carbon fuels are non-porous materials. The oxygen functional groups of fuel surface were more dominant. The decomposition gases were produced from the surface oxygen functional groups. These are reacted as sub-fuel of DCFC and improved DCFC performance.

3) In case of treated coals, the uniformity of current distribution was better than raw coal due to effect of additional functional groups. From these results, both acid treatments decreased the charge transfer resistance $\left(\mathrm{HNO}_{3}\right.$ treated coal $<\mathrm{HCl}$ treated coal $<$ raw coal).

\section{Acknowledgements}

This research was supported by Basic Science Research Program through the National Research Foundation of Korea(NRF) funded by the Ministry of Science, ICT \& Future Planning(NRF2015R1A2A2A01005137) and the Human Resources Development program(No. 20144010200780) of the Korea Institute of Energy Technology Evaluation and Planning(KETEP) grant funded by the Korea government Ministry of Trade, Industry and Energy.

\section{References}

[1] X. Li, Z. H. Zhu, R. D. Marco, A. Dicks, J. Bradley, S. Liu, and G. Q. Lu, Factors that determine the performance of carbon fuels in the direct carbon fuel cell," Ind. Eng. Chem. Res., vol. 47(23), pp. 9670-9677, 2008. 
116 10 $10^{\mathrm{TH}}$ InTERnAtional CONFERENCE ON Sustainable ENERGy AND ENVIRONMENTAL Protection (June $27^{\mathrm{TH}}-30^{\mathrm{TH}}, 2017$, Bled, Slovenia), Hydrogen ANd Fuel Cells

S. Eom, S. Ahn, G. Choi \& D. Kim: Electrochemical Resistance Reduction by Acid Treatment of Coal in Direct Carbon Fuel Cell

[2] S.Eom, J. Cho, S. Ahn, Y. Sung, G. Choi, and D. Kim, "Comparison of the Electrochemical Reaction Parameter of Graphite and Sub-bituminous Coal in a Direct Carbon Fuel Cell," Energy Fuels, vol. 30(4), pp. 3502-3508, 2016.

[3] X. Li, Z. Zhu, R. De Marco, J. Bradley, A. J. Dicks, "Evaluation of raw coals as fuels for direct carbon fuel cells," J. Power Sources, vol. 195(13), pp. 4051-4058, 2010.

[4] A. Elleuch, K. Halouani, and Y. Li, "Investigation of chemical and electrochemical reactions mechanisms in a direct carbon fuel cell using olive wood charcoal as sustainable fuel," J. Power Sources, vol. 281, pp. 350-361, 2015.

[5] S. Ahn, S. Eom, Y. Rhie, Y. Sung, C. Moon, G. Choi, and D. Kim, "Utilization of wood biomass char in a direct carbon fuel cell (DCFC) system." Appl. Energy, vol. 105, pp. $207-$ 216, 2013.

[6] S. Eom, S. Ahn, Y. Rhie, K. Kang, Y. Sung, C. Moon, G. Choi, and D. Kim, "Influence of devolatilized gases composition from raw coal fuel in the lab scale DCFC (direct carbon fuel cell) system," Energy, vol. 74, pp. 734-740, 2014.

[7] A. J. Minchener, "Coal gasification for advanced power generation," Fuel, vol. 84(17), pp. 2222-2235, 2005.

[8] X. Li, Z. Zhu, J. Chen, R. D. Marco, A. Dicks, J. Bradley, and G. Lu, "Surface modification of carbon fuels for direct carbon fuel cells," J. Power Sources, vol. 186(1), pp. 1-9, 2009.

[9] F. J. López-Garzón, M. Domingo-García, M. Pérez-Mendoza, P. M. Alvarez, and V. Gómez-Serrano, "Textural and chemical surface modifications produced by some oxidation treatments of a glassy carbon," Langmuir, vol. 19(7), pp. 2838-2844, 2003.

[10] J. L. Figueiredo, M. F. R. Pereira, M. M. A. Freitas, and J. J. M. Orfao, "Modification of the surface chemistry of activated carbons," Carbon, vol. 37(9), pp. 1379-1389, 1999.

[11] Q. L.Zhuang, T. Kyotani, and A. Tomita, "Drift and TK TPD analyses of surface oxygen complexes formed during carbon gasification," Energy fuels, vol. 8(3), pp. 714-718, 1994.

[12] U. Zielke, K. J. Hüttinger, and W. P. Hoffman, "Surface-oxidized carbon fibers: I. Surface structure and chemistry," Carbon, vol. 34(8), pp. 983-998, 1996.

[13] E. Desimoni, G. I. Casella, A. Morone, and A. M. Salvi, "XPS determination of oxygencontaining functional groups on carbon-fibre surfaces and the cleaning of these surfaces," Surf. Interface Anal., vol. 15(10), pp. 627-634, 1990.

[14] A. C. Lee, R. E. Mitchell, and T. M. Gür, "Thermodynamic analysis of gasification-driven direct carbon fuel cells," J. Power Sources, vol. 194(2), pp. 774-785, 2009.

[15] W. Hao, X. He, and Y. Mi, "Achieving high performance in intermediate temperature direct carbon fuel cells with renewable carbon as a fuel source," Appl. Energy, vol. 135, pp. 174181, 2014. 
$10^{\mathrm{TH}}$ InTERnational CONFEREnCE ON Sustainable ENERgy AND

ENVIRONMENTAL Protection (June $27^{\mathrm{TH}}-30^{\mathrm{TH}}$, 2017, Bled, Slovenia), Hydrogen AND Fuel Cells

J. Krope, A.Ghani Olabi, D. Goričanec \& S. Božičnik

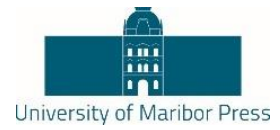

\title{
Rapid Synthesis of $\mathrm{Co} / \mathrm{CeO}_{2}$ Nanoparticles for Selective Oxidation of Carbon Monoxide in $\mathrm{H}_{2}$-Rich Stream
}

\author{
Liping Zhong, Dingkai Chen, KeZhen Chen, Jichang Lu, Jing Wang, CAiYun Han, \\ \& YONGMING LUO
}

\begin{abstract}
A series of $\mathrm{Co}(x) / \mathrm{CeO}_{2}(x=5$ wt.\%, 10 wt.\%, 15 wt.\% and 20 wt.\%) catalysts have been prepared via a facile and rapid route. The obtained catalyst samples were estimated for preferential oxidation of $\mathrm{CO}$ in $\mathrm{H}_{2}$-rich stream, and it is found that the optimal loading of $\mathrm{Co}$ is about 15 wt. \%. Moreover, the influences of $\mathrm{H}_{2} \mathrm{O}$ and $\mathrm{CO}_{2}$ together with catalytic stability have been investigated. In order to reveal the relationships among catalytic performances and the compositions, structural and physicochemical properties, the aforementioned catalysts were characterized by using $\mathrm{N}_{2}$ adsorption- desorption, XRD, TPR, TEM, Raman, UV-vis and XPS. It was documented that $\mathrm{Co}_{3} \mathrm{O}_{4}$ is a main active phase for $\mathrm{CO}$ preferential oxidation and the presence of strong interaction between $\mathrm{Co}_{3} \mathrm{O}_{4}$ and $\mathrm{CeO}_{2}$ should be responsible for the improving of catalytic performances.
\end{abstract}

Keywords: • CO selective oxidation $\bullet$ Co-Ce catalyst $\bullet$ nanoparticles • synthesis method $\bullet$ synergic interaction $\bullet$

CORRESPONDENCE ADDRESS: Liping Zhong, student, Kunming University of Science and Technology, Faculty of Environmental Science and Engineering, Kunming 650500, P. R China, email: 291336830@qq.com. Dingkai Chen, student, Kunming University of Science and Technology, Kunming 650500, P. R China, e-mail: 787019512@qq.com. Kezhen Chen., Student, Kunming University of Science and Technology, Faculty of Environmental Science and Engineering, Kunming 650500, P. R China, e-mail: 363685831@qq.com. Jichang Lu., Student, Kunming University of Science and Technology, Faculty of Environmental Science and Engineering, Kunming 650500, P. R China, e-mail: 18213453514@qq.com. Jing Wang, Student, Kunming University of Science and Technology, Faculty of Environmental Science and Engineering, Kunming 650500, P. R China, e-mail: 791394881@qq.com. Caiyun Han, Ph.D., Associate Professor, Kunming University of Science and Technology, Faculty of Environmental Science and Engineering, Kunming 650500, P. R China, e-mail:362979959@qq.com. Yongming Luo, Ph.D., Professor, Kunming University of Science and Technology, Faculty of Environmental Science and Engineering, Kunming 650500, P. R China, e-mail: environcatalysis222@ yahoo.com.

https://doi.org/10.18690/978-961-286-054-7.11

ISBN 978-961-286-054-7

(C) 2017 University of Maribor Press

Available at: http://press.um.si. 
$10^{\mathrm{TH}}$ InTERnATIONAL CONFERENCE ON Sustainable ENERgy AND ENVIRONMENTAL Protection (June $27^{\mathrm{TH}}-30^{\mathrm{TH}}, 2017$, Bled, Slovenia), Hydrogen and Fuel Cells L. Zhong, D. Chen, K. Chen, J. Lu, J. Wang, C. Han \& Y. Luo: Rapid Synthesis of $\mathrm{Co} / \mathrm{CeO}_{2}$ Nanoparticles for Selective Oxidation of Carbon Monoxide in $\mathrm{H}_{2}$-Rich Stream

Recently, considerable efforts have been devoted to remove the carbon monoxide existed in the hydrogen fuel.[1-4] Among the popular methods for $\mathrm{CO}$ removal from the $\mathrm{H}_{2}$-rich gases, carbon monoxide preferential oxidation (CO-PROX) is considered as the most efficient technique to reduce the $\mathrm{CO}$ in rich- $\mathrm{H}_{2}$ gas. Different catalysts, including noble metal-based and transition metal oxide-based catalysts, have been explored and studied for the CO-PROX.[5-7] However, the excessive cost of the noble metals limits its application at industrial level and encourages the development of new efficient and cheaper catalytic systems.

It was found that $\mathrm{Co}_{3} \mathrm{O}_{4}-\mathrm{CeO}_{2}$ system exhibited high conversion values at low temperatures.[8-10]. Traditionally, $\mathrm{Co}_{3} \mathrm{O}_{4}-\mathrm{CeO}_{2}$ catalysts have been synthesized coprecipitation method. [10] In this work, a rapid, simple and solvent-free method was used to synthesis $\mathrm{Co} / \mathrm{CeO}_{2}$ catalysts. Then they were tested for the $\mathrm{CO}-\mathrm{PROX}$ reaction in the presence of an excess of hydrogen. Moreover, the influence of $\mathrm{CO}_{2}$ and $\mathrm{H}_{2} \mathrm{O}$ on the $\mathrm{Co}-$ Ce catalysts was evaluated under the presence of $\mathrm{CO}_{2}$ and $\mathrm{H}_{2} \mathrm{O}$ in the feed, simulating a CO-PROX unit. In order to understand the catalytic behavior and the influence of the structural and chemical properties of obtained catalysts. The samples were characterized by XRD, Raman, TEM, XPS, $\mathrm{H}_{2}$-TPR and UV-vis to analyze the evolution of the active phase during the catalytic test.

\section{Experimental}

\subsection{Catalyst preparation}

The $\mathrm{Co}(x) / \mathrm{CeO}_{2}$ catalysts were prepared by urea grind combustion method (which is abbreviated to UGC. The nitrate of cobalt and cerium was added into urea within a moral ratio of 3/7[(cerium nitrate + cobalt nitrate)/urea] and materials was grinded in agate mortar under room temperature until the transparent viscous gel was obtained. After that, the gel was calcined at $600^{\circ} \mathrm{Cf}$ or 20 minutes and naturally cooled down to room temperature. A batch of catalysts with different ratios of cobalt and cerium were synthesized for CO-PROX test. The catalysts were denoted as $\mathrm{Co}(x) / \mathrm{CeO}_{2}$, where $x$ is referred to the calculated mass ratio of $\mathrm{Co} / \mathrm{CeO}_{2}$ of $5 \%, 10 \%, 15 \%$ and $20 \%$.

\subsection{Characterization}

XRD patterns were recorded by means of the Rigaku D/max-1200 diffract meter using $\mathrm{Cu} \mathrm{K} \alpha$ radiation at $2 \theta$ range between $20^{\circ}$ and $70^{\circ}$. The UV-vis were carried out at room temperature in the range $200-800 \mathrm{~nm}$ using $\mathrm{BaSO} 4$ as a reference. The XPS was performed on a PHI 5000 Versa Probe II with non-monochromatic Al Ka radiation $(1486.6 \mathrm{eV})$ as the excitation X-ray source. The $\mathrm{C} 1 \mathrm{~s}$ photoelectron peak at $284.6 \mathrm{eV}$ was used as a reference to calibrate binding energy. Raman spectra were detected by using a Via Reflex Confocal Raman Microscope with a laser $(613 \mathrm{~nm})$ working at $5 \mathrm{mV}$ power. Transmission electron microscopy (TEM) images were obtained using the JEOL JEM- 
$10^{\mathrm{TH}}$ INTERNATIONAL CONFERENCE ON SUSTAINABLE ENERGY AND ENVIRONMENTAL Protection (June $27^{\mathrm{TH}}-30^{\mathrm{TH}}, 2017$, Bled, Slovenia), ENERGy Storage

L. P. Zhong, D. K. Chen, K. Z. Chen, J. C. Lu, J. Wang, D. D. He, G. P. Wan, C. Y.

Han, S. F. He \& Y.M. Luo: Rapid Synthesis of $\mathrm{Co} / \mathrm{CeO}_{2}$ Nanoparticles for Selective

Oxidation of Carbon Monoxide in $\mathrm{H}_{2}$-Rich Stream

2100 microscope with an accelerating voltage of $300 \mathrm{kV}$. TPR experiment was carried out in the flow rate of $10 \% \mathrm{H} 2 / \mathrm{Ar}\left(30 \mathrm{~cm}^{3} / \mathrm{min}\right)$ by increasing temperature from $100{ }^{\circ} \mathrm{C}$ to $800{ }^{\circ} \mathrm{C}$ with a heating ramp of $10^{\circ} \mathrm{C} / \mathrm{min} . \mathrm{H}_{2}$ consumption was measured by an on- line thermal conductivity detector (TCD).

\subsection{Catalytic test}

$300 \mathrm{mg}$ of the catalyst with the particle size of 40- 60 meshes was loaded in a tubular reactor for CO-PROX test at atmospheric pressure between $80^{\circ} \mathrm{C}-220^{\circ} \mathrm{C}$. The feed gas was composed of $1 \% \mathrm{CO}, 1 \% \mathrm{O}_{2}$, and $50 \% \mathrm{H}_{2}$ in volume and balanced with He. The total flow rate was $80 \mathrm{ml} / \mathrm{min}$, corresponding to $24000 \mathrm{~h}^{-1} \mathrm{GHSV}$. The experiments for studying the effect of $\mathrm{CO}_{2}$ and $\mathrm{H}_{2} \mathrm{O}$ on catalytic activities were performed by the addition of $15 \% \mathrm{CO}_{2}$ and/or $10 \% \mathrm{H}_{2} \mathrm{O}$ into the feed gas, respectively. The inlet and outlet concentrations of reactants and products were analyzed by an on- line gas chromatography with TCD detector. The catalytic performances are expressed in terms of the $\mathrm{CO}$ conversion (\%) and the $\mathrm{CO}_{2}$ selectivity (\%), which was calculated based on the formula reported in the literature[11].

\section{$3 \quad$ Results and Discussion}

\subsection{The textual and structural properties}

The $\mathrm{N}_{2}$ adsorption-desorption isotherms were employed to determine the surface area and porous volumes. The textural parameters are compiled in Table 1.

Table 1. Texture Properties, Crystallite Size Of The Catalysts.

\begin{tabular}{ccccc}
\hline Sample & $\begin{array}{c}\text { Surface } \\
\text { area }\left(\mathrm{m}^{2} \mathrm{~g}^{-1}\right)\end{array}$ & $\begin{array}{c}\text { Pore volumeCrystallite } \\
\left(\mathrm{cm}^{3} \mathrm{~g}^{-1}\right)\end{array}$ & $\begin{array}{c}\text { Lattice } \\
\text { size }(\mathrm{nm})\end{array}$ & parameter $(\AA)$ \\
\hline $\mathrm{CeO}_{2}$ & 67.425 & 0.231 & 25.427 & 5.400 \\
$\mathrm{Co}(5) / \mathrm{CeO}_{2}$ & 17.167 & 0.029 & 18.487 & 5.393 \\
$\mathrm{Co}(10) / \mathrm{CeO}_{2}$ & 11.444 & 0.023 & 13.139 & 5.389 \\
$\mathrm{Co}(15) / \mathrm{CeO}_{2}$ & 7.010 & 0.017 & 14.686 & 5.393 \\
$\mathrm{Co}(20) / \mathrm{CeO}_{2}$ & 7.233 & 0.020 & 13.454 & 5.389 \\
\hline
\end{tabular}

It was seen that the incorporation of cobalt into $\mathrm{CeO}_{2}$ caused dramatic decrease in the surface area and pore volume. For the $\mathrm{Co} / \mathrm{CeO}_{2}$ system, the surface area reduced with the increase of Co content. It was worth noting that the trend of the catalytic activity was not in accordance with that of the surface area. This might reach a conclusion that the BET surface area was not a key role in the catalytic performance for CO-PROX in the present study. 
$10^{\mathrm{TH}}$ InTERnATIONAL CONFERENCE ON Sustainable EnERgy AND ENVIRONMENTAL Protection (June $27^{\mathrm{TH}}-30^{\mathrm{TH}}, 2017$, Bled, Slovenia), Hydrogen and Fuel Cells L. Zhong, D. Chen, K. Chen, J. Lu, J. Wang, C. Han \& Y. Luo: Rapid Synthesis of $\mathrm{Co} / \mathrm{CeO}_{2}$ Nanoparticles for Selective Oxidation of Carbon Monoxide in $\mathrm{H}_{2}$-Rich Stream

The TEM images (Figure $\mathrm{S} 1$ in supporting information) for representative $\mathrm{Co}(10) / \mathrm{CeO}_{2}$ reveals that oxides prepared by the UGC method are highly agglomerated nanoparticles. The agglomeration might be responsible for the decrease in BET surface area. As shown in the picture, it is difficult to tell the $\mathrm{Co}_{3} \mathrm{O}_{4}$ particle while it's easy to identify the $\mathrm{CeO}_{2}$ through lattice structure analysis at high resolution with lattice fringe spacing of $0.31 \mathrm{~nm}$ for $\mathrm{CeO}_{2}$ ([111]).[12]

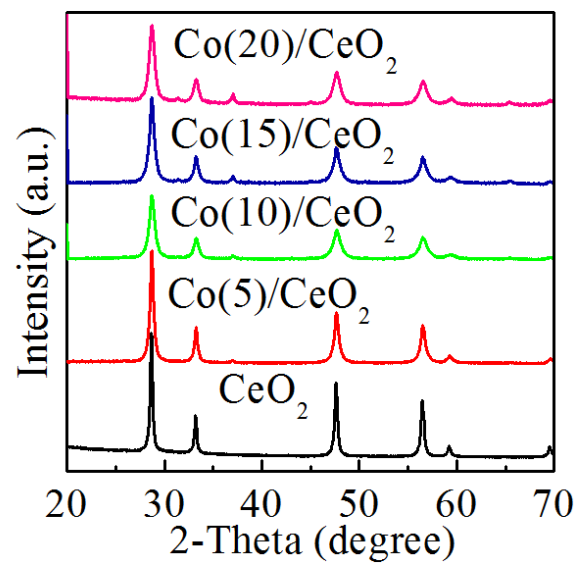

Figure 1. The XRD Patterns Of Pure $\mathrm{CeO}_{2}$ And $\mathrm{Co}(x) / \mathrm{CeO}_{2}$ Catalysts.

The XRD profiles of pure $\mathrm{CeO}_{2}$ and $\mathrm{Co}(x) / \mathrm{CeO}_{2}$ catalysts are presented in Figure 1. For all samples, five main peaks ascribing to typical fluorite structure of $\mathrm{CeO}_{2}$ were observed at around $2 \theta=28.4^{\circ}, 33.1^{\circ}, 47.5^{\circ}, 56.4^{\circ}$, and $59^{\circ}(\mathrm{JCPDS} 34-0394.1)$. In the $\mathrm{Co}(20) / \mathrm{CeO}_{2}$ catalyst, four peaks $\left(2 \theta=31.3^{\circ}, 36.9^{\circ}, 44.8^{\circ}\right.$ and $\left.65.3^{\circ}\right)$ corresponding to $\mathrm{Co} 3 \mathrm{O} 4$ were observed, while only weak signals of $\mathrm{Co}_{3} \mathrm{O}_{4}$ at $2 \theta=36.9^{\circ}$ and $65.3^{\circ}$ appear in other $\mathrm{Co}$ $(x) / \mathrm{CeO}_{2}$ samples due to their low concentration. However, no reflection of $\mathrm{CoO}$ and $\mathrm{Co}_{2} \mathrm{O}_{3}$ were detected by the XRD, which possibly indicated that only $\mathrm{Co}_{3} \mathrm{O}_{4}$ and $\mathrm{CeO}_{2}$ oxides were formed, this is accordant with the result of UV-vis and Raman Spectra. The broadening peaks of $\mathrm{CeO}_{2}$ appear in the $\mathrm{Co}(x) / \mathrm{CeO}_{2}$ samples as shown in Figure 1, suggesting that the structure of $\mathrm{CeO}_{2}$ is distorted due to the insertion of Co. The radius of $\mathrm{Co}^{2+}$ and $\mathrm{Co}^{3+}$ is both smaller than that of $\mathrm{Ce}^{4+} \cdot[13]$ This might lead to the decrease of the crystallite size in $\mathrm{Co} / \mathrm{CeO}_{2}$ catalysts determined by Scherrer equation, which was presented in Table 1. 
L. P. Zhong, D. K. Chen, K. Z. Chen, J. C. Lu, J. Wang, D. D. He, G. P. Wan, C. Y. Han, S. F. He \& Y.M. Luo: Rapid Synthesis of $\mathrm{Co} / \mathrm{CeO}_{2}$ Nanoparticles for Selective

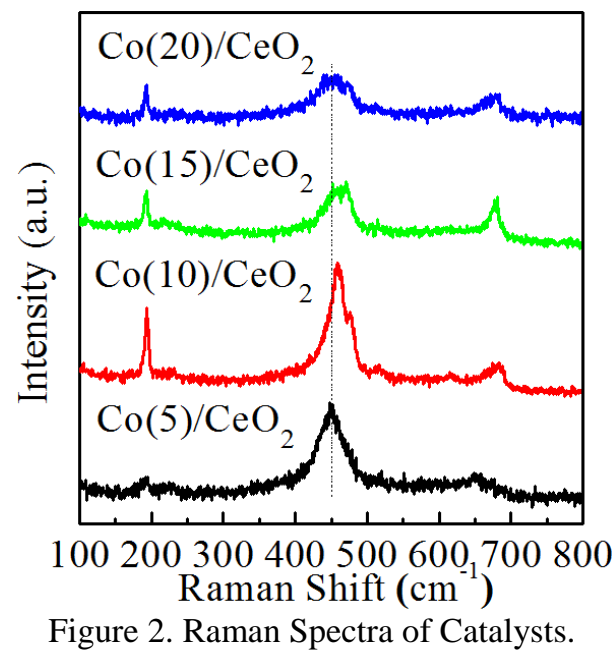

The Raman spectra of four $\mathrm{Co} / \mathrm{CeO}_{2}$ catalysts are shown in Figure 2. The peaks at around $193 \mathrm{~cm}^{-1}$ and $680 \mathrm{~cm}^{-1}$ could be assigned to the $F_{2 g}$ active mode and $A_{1 \mathrm{~g}}$ mode of the spinel Co3O4, respectively. [14]The band at around $460 \mathrm{~cm}^{-1}$ has been ascribed to a cubic fluorite $\mathrm{CeO}$ 2.[15] Additionally, the spectra of typical fluorite of $\mathrm{CeO}_{2}$ was broadened with the loading of $\mathrm{Co}$, which is consistent with the result in XRD. This might be due to an interaction between $\mathrm{Co}$ and $\mathrm{Ce}$ caused by the change of $\mathrm{Co}^{3+} / \mathrm{Co}^{2+}$ in the composition of $\mathrm{Co}_{3} \mathrm{O}_{4}$ oxide[13]. It has also been reported that the presence of $\mathrm{Co}^{2+}$ in the $\mathrm{CeO}_{2}$ lattice would deform the structure, which would favor oxygen mobility.[16, 17] Accordingly, the fluorite-characteristic peak intensity decreased with increase of Co loading.

The UV-vis spectrums of nanocrystalline $\mathrm{Co} / \mathrm{CeO}_{2}$ samples are presented in Figure S2 in supporting information. The adsorption peaks cantered at around $300 \mathrm{~nm}$ have been attributed to the metal charge transfer $\left(\mathrm{O}^{2} \rightarrow \rightarrow \mathrm{Ce}^{4+}\right)$ of $\mathrm{CeO}_{2}$ clusters. [18] There are two absorption peaks were observed at $720 \mathrm{~nm}$ and $470 \mathrm{~nm}$ which were assigned to ligandmetal charge transfer of $\mathrm{O}(\mathrm{II}) \rightarrow \mathrm{Co}(\mathrm{III})$ and $\mathrm{O}(\mathrm{II}) \rightarrow \mathrm{Co}(\mathrm{II})$, respectively. [19]These transitions confirmed the existence of spinel $\mathrm{Co}_{3} \mathrm{O}_{4}$ and fluorite $\mathrm{CeO}_{2}$ phase, which was consistent with Raman results and XRD patterns. 

Protection (June $27^{\mathrm{TH}}-30^{\mathrm{TH}}, 2017$, Bled, Slovenia), Hydrogen and Fuel Cells L. Zhong, D. Chen, K. Chen, J. Lu, J. Wang, C. Han \& Y. Luo: Rapid Synthesis of $\mathrm{Co} / \mathrm{CeO}_{2}$ Nanoparticles for Selective Oxidation of Carbon Monoxide in $\mathrm{H}_{2}$-Rich Stream

\subsection{Electronic and redox properties}

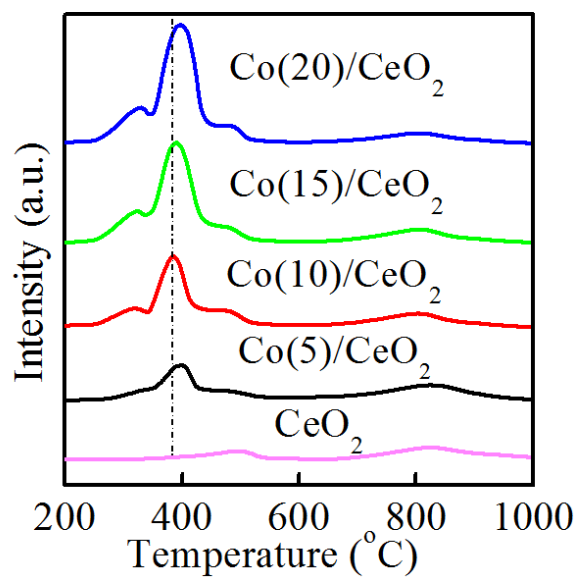

Figure 3. $\mathrm{H}_{2}$-TPR Profiles $\mathrm{Of} \mathrm{CeO}_{2}$ And Catalysts.

The $\mathrm{H} 2$-TPR profiles of pure $\mathrm{CeO}_{2}$ and $\mathrm{Co} / \mathrm{CeO}_{2}$ catalysts are collected and presented in Figure 3 for the analysis of redox properties. Two reduction peaks at about $499^{\circ} \mathrm{C}$ and $820^{\circ} \mathrm{C}$ are obtained on pure $\mathrm{CeO}_{2}$ [20], suggesting the successive reduction steps of the superficial oxygen of $\mathrm{CeO}_{2}[21,22]$. All $\mathrm{Co} / \mathrm{CeO}_{2}$ samples play a peak at $820^{\circ} \mathrm{C}$ due to the reduction of bulk $\mathrm{CeO}_{2}$, and the reduction peaks below this temperature are mainly related to $\mathrm{Co}_{3} \mathrm{O}_{4}$ phase because cobalt species have a much higher reducibility, as compared with $\mathrm{CeO}_{2}$.[23] With the increase of cobalt loading, the increase of $\mathrm{H}_{2}$ consumption of the reduction of highly dispersed $\mathrm{Co}_{3} \mathrm{O}_{4}$ and reducible $\mathrm{Co}^{3+}$ was observed.[14] In the $\mathrm{Co}(10) / \mathrm{CeO}_{2}$ and $\mathrm{Co}(15) / \mathrm{CeO}_{2}$ samples, all of the reduction peaks have slightly shifted to a lower temperature may due to the synergetic effect between $\mathrm{Co}_{3} \mathrm{O}_{4}$ and $\mathrm{CeO}_{2}$.

XPS was carried out to investigate the electronic properties of $\mathrm{Co}$ and $\mathrm{Ce}$ in $\mathrm{Co} / \mathrm{CeO}_{2}$ catalysts. For comparison, the spectra of pure $\mathrm{Co}_{3} \mathrm{O}_{4}$ was also collected. The corresponding spectra of $\mathrm{Ce} 3 \mathrm{~d}$, Co $2 \mathrm{p}$ and O1s were shown in Figure 4 and Figure 5 respectively. Based on the intensity of fitted curves, the relative amounts of $\mathrm{Co}^{2+}$ and $\mathrm{Ce}^{3+}$ were calculated and complied in Table 2 . 
$10^{\mathrm{TH}}$ INTERNATIONAL CONFERENCE ON SUSTAINABLE ENERGY AND ENVIRONMENTAL Protection (June $27^{\mathrm{TH}}-30^{\mathrm{TH}}, 2017$, Bled, Slovenia), ENERGy Storage

L. P. Zhong, D. K. Chen, K. Z. Chen, J. C. Lu, J. Wang, D. D. He, G. P. Wan, C. Y.

Han, S. F. He \& Y.M. Luo: Rapid Synthesis of $\mathrm{Co} / \mathrm{CeO}_{2}$ Nanoparticles for Selective

Oxidation of Carbon Monoxide in $\mathrm{H}_{2}$-Rich Stream

Table 2. The Relative Amounts of Co And Ce On The Surface of Catalysts.

\begin{tabular}{cccc}
\hline \multirow{2}{*}{ Samples } & \multirow{3}{*}{$\begin{array}{c}\text { Content of } \\
\mathrm{Co}(\%)\end{array}$} & $\begin{array}{c}\text { Relative content atom } \\
\text { \% of Ce species }\end{array}$ & $\begin{array}{c}\text { Relative content } \\
\text { atom \% of Co species }\end{array}$ \\
\cline { 3 - 4 } & & $\mathrm{Ce}^{3+} /\left(\mathrm{Ce}^{3+}+\mathrm{Ce}^{4+}\right)$ & $\mathrm{Co}^{2+} /\left(\mathrm{Co}^{3+}+\mathrm{Co}^{2+}\right)$ \\
\hline $\mathrm{Co}_{3} \mathrm{O}_{4}$ & 100 & - & 71.8479 \\
$\mathrm{Co}(5) / \mathrm{CeO}_{2}$ & 3.178 & 8.9511 & 39.6539 \\
$\mathrm{Co}(10) / \mathrm{CeO}_{2}$ & 8.029 & 12.3326 & 55.7437 \\
$\mathrm{Co}(15) / \mathrm{CeO}_{2}$ & 12.788 & 12.9461 & 66.5600 \\
$\mathrm{Co}(20) / \mathrm{CeO}_{2}$ & 19.553 & 12.0762 & 65.5296 \\
\hline
\end{tabular}

Figure 4 shows the Co2p spectra and O1s spectra of Co-containing materials. For all samples, the characteristic of Co $\left(2 \mathrm{p}_{3 / 2}\right)$ at the binding energy of $779 \mathrm{eV}$ can be decomposed into two components of $\mathrm{Co} 2+$ and $\mathrm{Co} 3+$, while the peak of $\mathrm{Co}\left(2 \mathrm{p}_{1 / 2}\right.$ arises at $794 \mathrm{eV}$. The satellite peak appears at $785 \mathrm{eV}$ above the main peak can be seen as a broad peak.[16] It has been reported that the sharp and more intense component at lower binding energy is ascribed to $\mathrm{Co}^{3+}$, whereas the shoulder at higher binding energy represents the $\mathrm{Co}^{2+}$ component.[24] The highest content of $\mathrm{Co}^{2+}$ observed in $\mathrm{Co}(15) / \mathrm{CeO}_{2}$, which improves the formation of $\mathrm{Ce}^{3+}$, resulting in a better oxygen mobility as well as the best oxidation activity.

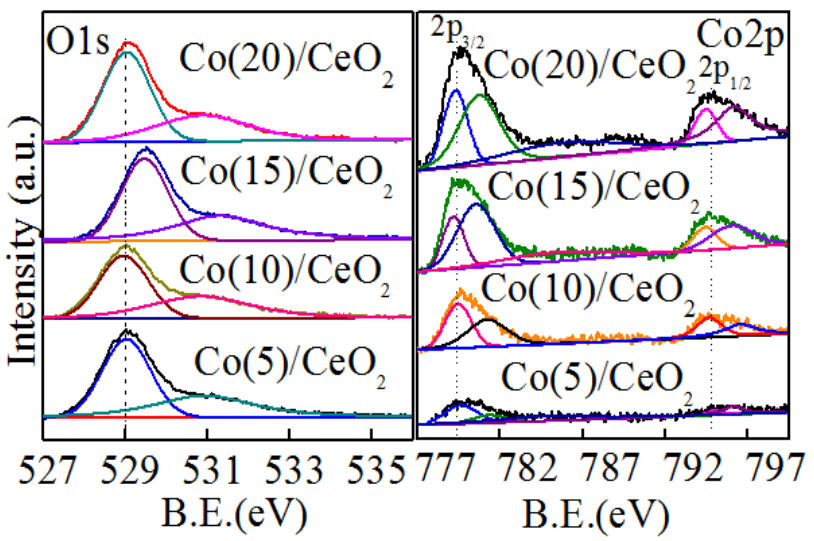

Figure 4. The Spectra Of O1s And Co2p Of Catalysts.

As shown in Figure 5, the curve of Ce 3d peaks in this study are the same as those described in the literature. [25, 26]. The presence of $\mathrm{Ce}^{3+}$ is attributed to the interaction between ceria and the surrounding atoms, and it also implies that the surface of $\mathrm{CeO}_{2}$ (111) is not fully oxidized and contains some oxygen vacancies[27]. 
124 10 $10^{\mathrm{TH}}$ International Conference On Sustainable EnERgy and Environmental Protection (June $27^{\mathrm{TH}}-30^{\mathrm{TH}}, 2017$, Bled, Slovenia), Hydrogen and Fuel Cells L. Zhong, D. Chen, K. Chen, J. Lu, J. Wang, C. Han \& Y. Luo: Rapid Synthesis of $\mathrm{Co} / \mathrm{CeO}_{2}$ Nanoparticles for Selective Oxidation of Carbon Monoxide in $\mathrm{H}_{2}$-Rich Stream

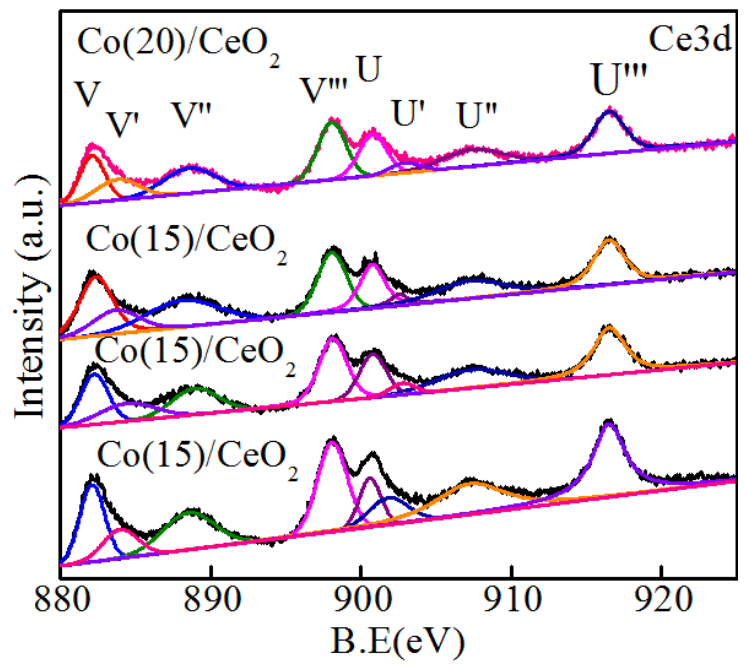

Figure 5. The Spectra of Ce3d of Catalysts.

It could be seen that the relative concentration of $\mathrm{Ce}^{3+}$ was changed with the content of $\mathrm{Co}$, showing a highest value on $\mathrm{Co}(15) / \mathrm{CeO}_{2}$. The trend of the change on $\mathrm{Ce}^{3+}$ is perfectly consistent with that of catalytic performance. It was reported [28] that high relative amount of $\mathrm{Ce}^{3+}$ indicated a high concentration of oxygen vacancies which contributed to improve oxygen mobility and thus enhanced the catalytic oxidation activity. Therefore, it was reasonable that the O1S peak of $\mathrm{Co}(15) / \mathrm{CeO}_{2}$ shifted towards a higher binding energy, suggesting a better oxygen mobility. Consequently, the $\mathrm{Co}(15) / \mathrm{CeO}_{2}$ exhibited the best activity for $\mathrm{CO}$ selective oxidation.

\subsection{Catalytic performance}
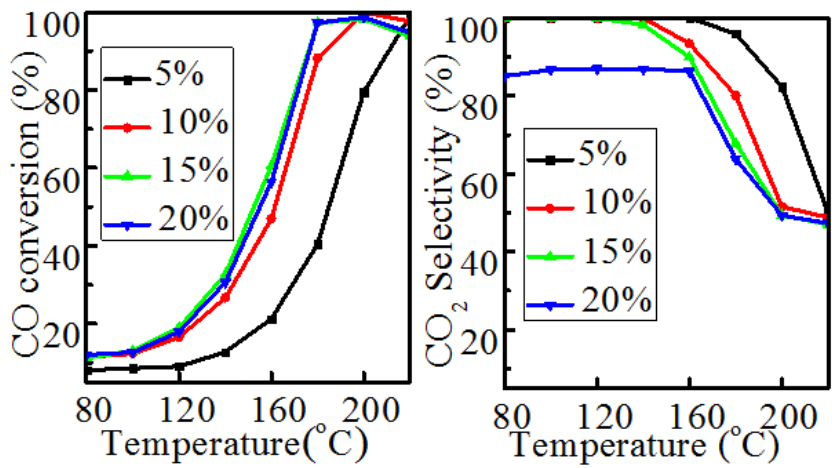

Figure 6. The Activity of $\mathrm{Co}(x=5 \%, 10 \%, 15 \%, 20 \%) / \mathrm{CeO}_{2}$ Catalysts on CO-PROX 
$10^{\mathrm{TH}}$ INTERNATIONAL CONFERENCE ON SUSTAINABLE ENERGY AND ENVIRONMENTAL Protection (June $27^{\mathrm{TH}}-30^{\mathrm{TH}}, 2017$, Bled, Slovenia), ENERGy Storage

L. P. Zhong, D. K. Chen, K. Z. Chen, J. C. Lu, J. Wang, D. D. He, G. P. Wan, C. Y.

Han, S. F. He \& Y.M. Luo: Rapid Synthesis of $\mathrm{Co} / \mathrm{CeO}_{2}$ Nanoparticles for Selective

Oxidation of Carbon Monoxide in $\mathrm{H}_{2}$-Rich Stream

Figure 6 shows the conversion of $\mathrm{CO}$ and selectivity towards $\mathrm{CO}_{2}$ of the $\mathrm{Co}(\mathrm{x}) / \mathrm{CeO}_{2}$ catalysts for the removal of $\mathrm{CO}$ in the rich- $\mathrm{H}_{2}$ gas. In all cases, the conversion increases with the reaction temperature as well as with the cobalt content, being the best performance for $\mathrm{Co}(15) / \mathrm{CeO}_{2}$ catalyst which exhibited conversion values close to $95 \%$ at $160^{\circ} \mathrm{C}$. Nevertheless the $\mathrm{CO}$ conversion slightly decreases for the catalyst with the highest cobalt content $\left(\mathrm{Co}(20) / \mathrm{CeO}_{2}\right)$. This fact could be ascribed to a decay of dispersion of the active phase which can lead to a decrease of the available active sites for the COPROX. Moreover, the influence of $\mathrm{H}_{2} \mathrm{O}$ and $\mathrm{CO}_{2}$ together with the stability on the $\mathrm{Co}(10) / \mathrm{CeO}_{2}$ catalyst was studied, the results can be seen in supporting information.

\section{Conclusion}

$\mathrm{Co}(x) / \mathrm{CeO}_{2}$ catalysts prepared by UGC method exhibited a good catalytic performance and stability for CO-PROX. The particle size of the catalysts is at average of $14.9 \mathrm{~nm}$ due to the highly agglomeration. $\mathrm{Co}_{3} \mathrm{O}_{4}$ is the unique Co oxide as confirmed with $\mathrm{XRD}$, Raman and UV-vis. The interaction between $\mathrm{Co}$ and $\mathrm{CeO}_{2}$ plays a more important role than that of Co content and temperature in the catalytic performance. The interaction was formed due to the change in the relative content $\mathrm{Co}^{2+}$ and $\mathrm{Ce}^{3+}$, resulted in an increase of oxygen mobility in the $\mathrm{Co} / \mathrm{CeO}_{2}$ catalyst system according to the XPS results.

\section{Acknowledgements}

We gratefully acknowledge the financial supports of the National Natural Science Foundation of China (Grant No. U1402233, 21267011 and 21367015).

\section{References}

[1] J. S. Elias, N. Artrith, M. Bugnet, L. Giordano, G. A. Botton, A. M. Kolpak, et al., "Elucidating the Nature of the Active Phase in Copper/Ceria Catalysts for CO Oxidation," ACS Catalysis, vol. 6, pp. 1675-1679, 2016/03/04 2016.

[2] R. Fiorenza, C. Crisafulli, and S. ScirÃ", "H2 purification through preferential oxidation of $\mathrm{CO}$ over ceria supported bimetallic Au-based catalysts," International Journal of Hydrogen Energy, vol. 41, pp. 19390-19398, 11/9/ 2016.

[3] L. F. Peiretti, N. Navascués, I. S. Tiscornia, and E. E. Miró, "CeO2 and $\mathrm{Co3O} 4-\mathrm{CeO} 2$ nanoparticles: effect of the synthesis method on the structure and catalytic properties in COPrOx and methanation reactions," Journal of Materials Science, vol. 51, pp. 3989-4001, 2016.

[4] L. s. Soler, A. Casanovas, A. Urrich, I. Angurell, and J. Llorca, "CO oxidation and COPrOx over preformed $\mathrm{Au}$ nanoparticles supported over nanoshaped CeO2," Applied Catalysis B: Environmental, vol. 197, pp. 47-55, 11/15/ 2016.

[5] J. Wang, L. Deng, D. He, J. Lu, S. He, S. He, et al., "A facile and rapid route to synthesize $\mathrm{CuOx} / \mathrm{Ce} 0.8 \mathrm{Zr} 0.2 \mathrm{O} 2$ catalysts with high performance for $\mathrm{CO}$ preferential oxidation (COPROX)," International Journal of Hydrogen Energy, vol. 40, pp. 12478-12488, 9/28/ 2015.

[6] J. Wang, C. Han, X. Gao, J. Lu, G. Wan, D. He, et al., "Rapid synthesis of Fe-doped CuO$\mathrm{Ce} 0.8 \mathrm{Zr} 0.2 \mathrm{O} 2$ catalysts for $\mathrm{CO}$ preferential oxidation in H2-rich streams: Effect of iron source and the ratio of $\mathrm{Fe} / \mathrm{Cu}$," Journal of Power Sources, vol. 343, pp. 437-445, 3/1/ 2017. 
$10^{\mathrm{TH}}$ INTERNATIONAL CONFERENCE ON Sustainable ENERGY AND ENVIRONMENTAL Protection (June $27^{\mathrm{TH}}-30^{\mathrm{TH}}, 2017$, Bled, Slovenia), Hydrogen and Fuel Cells L. Zhong, D. Chen, K. Chen, J. Lu, J. Wang, C. Han \& Y. Luo: Rapid Synthesis of $\mathrm{Co} / \mathrm{CeO}_{2}$ Nanoparticles for Selective Oxidation of Carbon Monoxide in $\mathrm{H}_{2}$-Rich Stream

[7] Q. Zhang, X. Liu, W. Fan, and Y. Wang, "Manganese-promoted cobalt oxide as efficient and stable non-noble metal catalyst for preferential oxidation of CO in $\mathrm{H} 2$ stream," Applied Catalysis B: Environmental, vol. 102, pp. 207-214, 2011.

[8] Q. Guo and Y. Liu, "MnOx modified $\mathrm{Co} 3 \mathrm{O} 4-\mathrm{CeO} 2$ catalysts for the preferential oxidation of CO in H2-rich gases," Applied Catalysis B: Environmental, vol. 82, pp. 19-26, 2008.

[9] M. P. Woods, P. Gawade, B. Tan, and U. S. Ozkan, "Preferential oxidation of carbon monoxide on $\mathrm{Co} / \mathrm{CeO} 2$ nanoparticles," Applied Catalysis B: Environmental, vol. 97, pp. 28-35, 6/9/ 2010.

[10] P. Gawade, B. Bayram, A.-M. C. Alexander, and U. S. Ozkan, "Preferential oxidation of $\mathrm{CO}(\mathrm{PROX})$ over $\mathrm{CoOx} / \mathrm{CeO} 2$ in hydrogen-rich streams: Effect of cobalt loading," Applied Catalysis B: Environmental, vol. 128, pp. 21-30, 2012.

[11] C.-F. Yan, H. Chen, R.-R. Hu, S. Huang, W. Luo, C. Guo, et al., "Synthesis of mesoporous $\mathrm{Co}-\mathrm{Ce}$ oxides catalysts by glycine-nitrate combustion approach for $\mathrm{CO}$ preferential oxidation reaction in excess H2," International Journal of Hydrogen Energy, vol. 39, pp. 18695-18701, 2014.

[12] S. Zeng, L. Zhang, N. Jiang, M. Gao, X. Zhao, Y. Yin, et al., "Multi-wall carbon nanotubes as support of copper-cerium composite for preferential oxidation of carbon monoxide," Journal of Power Sources, vol. 293, pp. 1016-1023, 2015.

[13] S. K. Mahammadunnisa, T. Akanksha, K. Krushnamurty, and C. H. Subrahmanyam, "Catalytic decomposition of $\mathrm{N} 2 \mathrm{O}$ over $\mathrm{CeO} 2$ supported $\mathrm{Co} 3 \mathrm{O} 4$ catalysts," Journal of Chemical Sciences, vol. 128, pp. 1795-1804, 2016.

[14] L. He, Z. Li, and Z. Zhang, "Rapid, low-temperature synthesis of single-crystalline Co3O4 nanorods on silicon substrates on a large scale," Nanotechnology, vol. 19, p. 155606, Apr 162008.

[15] T. Cwele, N. Mahadevaiah, S. Singh, and H. B. Friedrich, "Effect of Cu additives on the performance of a cobalt substituted ceria $(\mathrm{Ce} 0.90 \mathrm{Co} 0.1 \mathrm{O} 2$-delta) catalyst in total and preferential CO oxidation," Applied Catalysis B-Environmental, vol. 182, pp. 1-14, Mar 2016.

[16] B. M. Reddy, A. Khan, Y. Yamada, T. Kobayashi, S. Loridant, and J.-C. Volta, "Structural Characterization of $\mathrm{CeO} 2-\mathrm{MO} 2(\mathrm{M}=\mathrm{Si} 4+$, $\mathrm{Ti} 4+$, and $\mathrm{Zr} 4+)$ Mixed Oxides by Raman Spectroscopy, X-ray Photoelectron Spectroscopy, and Other Techniques," The Journal of Physical Chemistry B, vol. 107, pp. 11475-11484, 2003/10/01 2003.

[17] L. Dong, Y. Hu, M. Shen, T. Jin, J. Wang, W. Ding, et al., "Dispersion Behaviors of Copper Oxide on the Mixed "CeO2 $+\gamma$-A12O3" Support," Chemistry of Materials, vol. 13, pp. 4227-4232, 2001/11/01 2001.

[18] Z. Li and M. Flytzani-Stephanopoulos, "On the Promotion of Ag-ZSM-5 by Cerium for the SCR of NO by Methane," Journal of Catalysis, vol. 182, pp. 313-327, 1999/03/10 1999.

[19] T. Warang, N. Patel, R. Fernandes, N. Bazzanella, and A. Miotello, "Co3O4 nanoparticles assembled coatings synthesized by different techniques for photo-degradation of methylene blue dye," Applied Catalysis B: Environmental, vol. 132-133, pp. 204-211, 3/27/ 2013.

[20] D. Shang, Q. Zhong, and W. Cai, "Influence of the preparation method on the catalytic activity of $\mathrm{Co} / \mathrm{Zr} 1-\mathrm{xCexO} 2$ for $\mathrm{NO}$ oxidation," Journal of Molecular Catalysis A: Chemical, vol. 399, pp. 18-24, 2015.

[21] L. Katta, P. Sudarsanam, G. Thrimurthulu, and B. M. Reddy, "Doped nanosized ceria solid solutions for low temperature soot oxidation: Zirconium versus lanthanum promoters," Applied Catalysis B: Environmental, vol. 101, pp. 101-108, 11/22/ 2010.

[22] A. Arango-Diaz, J. A. Cecilia, J. Marrero-Jerez, P. Nuñez, J. Jiménez-Jiménez, and E. Rodríguez-Castellón, "Freeze-dried $\mathrm{Co} 3 \mathrm{O} 4-\mathrm{CeO} 2$ catalysts for the preferential oxidation of $\mathrm{CO}$ with the presence of $\mathrm{CO} 2$ and $\mathrm{H} 2 \mathrm{O}$ in the feed," Ceramics International, vol. 42, pp. 7462-7474, 2016. 
L. P. Zhong, D. K. Chen, K. Z. Chen, J. C. Lu, J. Wang, D. D. He, G. P. Wan, C. Y. Han, S. F. He \& Y.M. Luo: Rapid Synthesis of $\mathrm{Co} / \mathrm{CeO}_{2}$ Nanoparticles for Selective

Oxidation of Carbon Monoxide in $\mathrm{H}_{2}$-Rich Stream

[23] J. Luo, M. Meng, X. Li, X. Li, Y. Zha, T. Hu, et al., "Mesoporous Co3O4-CeO2 and $\mathrm{Pd} / \mathrm{Co} 3 \mathrm{O} 4-\mathrm{CeO} 2$ catalysts: Synthesis, characterization and mechanistic study of their catalytic properties for low-temperature CO oxidation," Journal of Catalysis, vol. 254, pp. 310-324, 2008.

[24] G. Fierro, M. Lo Jacono, M. Inversi, R. Dragone, and P. Porta, "TPR and XPS study of cobalt-copper mixed oxide catalysts: evidence of a strong $\mathrm{Co}-\mathrm{Cu}$ interaction," Topics in Catalysis, vol. 10, pp. 39-48, 2000.

[25] P. S. Barbato, A. Di Benedetto, G. Landi, and L. Lisi, "CuO/CeO2 based monoliths for $\mathrm{CO}$ preferential oxidation in H2-rich streams," Chemical Engineering Journal, vol. 279, pp. 983-993, 2015.

[26] Y. Gao, K. Xie, W. Wang, S. Mi, N. Liu, G. Pan, et al., "Structural features and catalytic performance in $\mathrm{CO}$ preferential oxidation of $\mathrm{CuO}-\mathrm{CeO} 2$ supported on multi-walled carbon nanotubes," Catal. Sci. Technol., vol. 5, pp. 1568-1579, 2015.

[27] Y. Liu, B. Liu, Q. Wang, C. Li, W. Hu, Y. Liu, et al., "Three-dimensionally ordered macroporous $\mathrm{Au} / \mathrm{CeO} 2-\mathrm{Co} 3 \mathrm{O} 4$ catalysts with mesoporous walls for enhanced $\mathrm{CO}$ preferential oxidation in H2-rich gases," Journal of Catalysis, vol. 296, pp. 65-76, 12/2012.

[28] L. F. Liotta, G. Di Carlo, G. Pantaleo, A. M. Venezia, and G. Deganello, "Co3O4/CeO2 composite oxides for methane emissions abatement: Relationship between $\mathrm{Co} 3 \mathrm{O} 4-\mathrm{CeO} 2$ interaction and catalytic activity," Applied Catalysis B: Environmental, vol. 66, pp. 217227, 7/20/ 2006. 
128 10 $10^{\mathrm{TH}}$ InTERnational CONFERENCE ON Sustainable EnERgy and EnVIRONMENTAL Protection (June 27 $7^{\mathrm{TH}}-30^{\mathrm{TH}}, 2017$, Bled, Slovenia), Hydrogen And Fuel Cells 
$10^{\mathrm{TH}}$ InTERnational CONFERENCE ON Sustainable ENERgy AND ENVIRONMENTAL Protection (June $27^{\mathrm{TH}}-30^{\mathrm{TH}}$, 2017, Bled, Slovenia), Hydrogen AND Fuel Cells

J. Krope, A.Ghani Olabi, D. Goričanec \& S. Božičnik

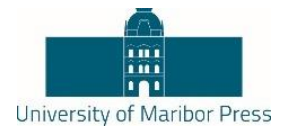

\title{
The Effect of Chloride Ions in Sn Doped $\mathrm{CuO}-\mathrm{CeO}_{2}$ Catalysts for Co Preferential Oxidation (CO-PROX) in $\mathrm{H}_{2}$ - Rich Stream
}

\author{
KEZHEN CHEN, LIPING ZHONG, JiCHANG LU, GENGPING WAN \& YONGMING LUO
}

\begin{abstract}
CO preferential oxidation is one of the most effective methods to eliminate $\mathrm{CO}$ from $\mathrm{H}_{2}$-rich stream. In the past decades, $\mathrm{CuO}-\mathrm{CeO}_{2}$ based catalysts have attributed considerable attention in this research field owing to the advantages of low cost, high activity and selectivity. A series of Sndoped $\mathrm{CuO}-\mathrm{CeO}_{2}$ catalysts (Named as $\mathrm{Sn}(\mathrm{x})-\mathrm{CuO}-\mathrm{CeO}_{2}, \mathrm{x}=1 \%, 2.5 \%, 5 \%$ and $7.5 \mathrm{wt} . \%$ ) were rapidly synthesized via a facile and solvent-free route. The $\mathrm{CO}$ conversion of the optimal catalyst $\left(\mathrm{w} \mathrm{Sn}(5)-\mathrm{CuO}-\mathrm{CeO}_{2}\right)$ is $97.74 \%$ at $100 \mathrm{oC}$, and the influence of chloride ions on the surface of catalytic performance was investigated in detail. Furthermore, the obtained catalysts were characterized by using $\mathrm{N}_{2}$ adsorption-desorption, $\mathrm{H}_{2}-\mathrm{TPR}, \mathrm{XRD}$, XPS, Raman and TEM so as to understand the interrelationship between catalytic behaviors and physicochemical characteristics.
\end{abstract}

Keywords: $\bullet \mathrm{CO}$ preferential oxidation $\bullet \mathrm{CuO}-\mathrm{CeO}_{2} \cdot \mathrm{Sn}$ modification $\bullet$ chloride ion $\bullet$ catalyst $\bullet$

CoRrespondence AdDRESS: Kezhen Chen., Student, Kunming University of Science and Technology, Faculty of Environmental Science and Engineering, Kunming 650500, P. R China, email: 363685831@qq.com. Liping Zhong, student, Kunming University of Science and Technology, Faculty of Environmental Science and Engineering, Kunming 650500, P. R China, email: 291336830@ qq.com. Jichang Lu., Student, Kunming University of Science and Technology, Faculty of Environmental Science and Engineering, Kunming 650500, P. R China, e-mail: 18213453514@qq.com. Gengping Wan, Ph.D., Kunming University of Science and Technology, Faculty of Environmental Science and Engineering, Kunming 650500, P. R China, email:120802237@qq.com. Yongming Luo, Ph.D., Professor, Kunming University of Science and Technology, Faculty of Environmental Science and Engineering, Kunming 650500, P. R China, email: environcatalysis222@yahoo.com. 
$130 \quad 10^{\mathrm{TH}}$ International Conference On Sustainable EnERgy and EnVIRONMENTAL Protection (June $27^{\mathrm{TH}}-30^{\mathrm{TH}}, 2017$, Bled, Slovenia), Hydrogen and Fuel Cells K. Chen, L. Zhong, J. Lu, G. Wan \& Y. Luo: The Effect of Chloride Ions in Sn Doped $\mathrm{CuO}-\mathrm{CeO}_{2}$ Catalysts for Co Preferential Oxidation (CO-PROX) in $\mathrm{H}_{2}$-Rich Stream

The development of efficient catalysts for the $\mathrm{CO}$ preferential oxidation (CO-PROX) in the presence of $\mathrm{CO}$-contaminated $\mathrm{H}_{2}$-rich streams is a current challenge for use in polymer electrolyte membrane fuel cells (PEMFC)[1]. It's well known that the metal catalysts such as $\mathrm{CuO} / \mathrm{CeO}_{2}$ catalyst exhibited favorable catalytic activities[2]. $\mathrm{SnO}_{2}$ has been widely used as an oxidation catalyst because it can reversibly undergo transforming the $\mathrm{Sn}^{4+}$ and $\mathrm{Sn}^{2+}$ at relatively low temperature, so it is always be applied as a catalyst support or promoter[3].In this paper, $\mathrm{Sn}$ doped in $\mathrm{CuO}-\mathrm{CeO}_{2}$ catalysts $\left(\mathrm{Sn}(\mathrm{x})-\mathrm{CuO}-\mathrm{CeO}_{2}\right.$ ) were synthesized rapidly by a green and solvent-free route within $30 \mathrm{~min}$. However, the catalysts synthesized by this way contain a certain number of chloride ions. As reported before[4], the presence of chloride could poison the catalysts and make the worse catalysts performance, but there is no literature discussed about the influence of $\mathrm{Cl}^{-}$in $\mathrm{Sn}$ doped in $\mathrm{CuO}-\mathrm{CeO}_{2}$ catalysts for CO-PROX application. We improved the preparation method by removing the chloride ions in the $\mathrm{Sn}(\mathrm{x})-\mathrm{CuO}-\mathrm{CeO}_{2}$ (signed $\mathrm{wSn}(\mathrm{x})-\mathrm{CuO}-$ $\mathrm{CeO}_{2}$ samples) and found that these samples exhibited superior catalytic performance. In order to analyze the interaction between catalytic behaviors and physicochemical characteristics, $\mathrm{Sn}(\mathrm{x})-\mathrm{CuO}-\mathrm{CeO}_{2}$ and $\mathrm{wSn}(\mathrm{x})-\mathrm{CuO}-\mathrm{CeO}_{2}$ catalysts were characterized by $\mathrm{N}_{2}$ adsorption-desorption, XRD, TEM, Raman, XPS and $\mathrm{H}_{2}$-TPR measurements.

\section{$2 \quad$ Materials and Methods}

\subsection{Catalyst preparation}

All the catalysts were synthesized by urea grind combustion. Firstly, $\mathrm{Sn}(\mathrm{x})-\mathrm{CuO}-\mathrm{CeO}_{2}$ $(\mathrm{x}=1,2.5,5,7.5)$, which catalysts were prepared with $\mathrm{Ce}\left(\mathrm{NO}_{3}\right)_{3} \cdot 6 \mathrm{H}_{2} \mathrm{O}, \mathrm{Cu}\left(\mathrm{NO}_{3}\right)_{2} .3 \mathrm{H}_{2} \mathrm{O}$, $\mathrm{SnCl}_{4} .5 \mathrm{H}_{2} \mathrm{O}$ and $\left(\mathrm{NH}_{2}\right)_{2} \mathrm{CO}$, where the loading of $\mathrm{CuO}$ was kept at a constant of $12.5 \mathrm{wt} . \%$ and $\mathrm{x}$ meant the molar percentage of $\mathrm{SnO} / \mathrm{CeO}_{2}$. All the above experimental materials were mixed with a definite proportion in agate mortar and then grinded under the room temperature about ten minutes until the transparent viscous gel was obtained. Subsequently, the gel was put into the Muffle furnace and calcined at $600^{\circ} \mathrm{C}$ for 20 minutes. The resultant solids were respectively dissolved in $50 \mathrm{ml}$ deionized water and heated in boiling water bath at $80^{\circ} \mathrm{C}$ for $1 \mathrm{~h}$. Then filtrated and washed the mixture with hot deionized water until no $\mathrm{Cl}^{-}$was examined by $0.1 \mathrm{~mol} / \mathrm{L} \mathrm{AgNO}_{3}$ aqueous solution. The samples were dried at $120^{\circ} \mathrm{C}$, followed by calcination at $600^{\circ} \mathrm{C}$. The catalysts prepared via this route were noted $\mathrm{wSn}(\mathrm{x})-\mathrm{CuO}-\mathrm{CeO}_{2}$.

\subsection{Catalytic activity measurement}

Catalytic activity tests were tested in a quartz tubular in a continuous flow fixed bed reactor, using $0.3 \mathrm{~g}$ sample (in 40-60 mesh). The typical reaction gas mixture were consisted of $1 \% \mathrm{CO}, 1 \% \mathrm{O}_{2}, 50 \% \mathrm{H}_{2}$ in volume with $\mathrm{He}$ as the balance gas, passed through the catalyst bed reactor at a total flow rate of $80 \mathrm{ml} / \mathrm{min}$ and a GHSV $=24000 \mathrm{~h}^{-1}$. The exit gases were analyzed by gas chromatography equipped with a thermal conductivity 
$10^{\mathrm{TH}}$ INTERNATIONAL CONFERENCE ON SUSTAINABLE ENERGY AND ENVIRONMENTAL Protection (June $27^{\mathrm{TH}}-30^{\mathrm{TH}}, 2017$, Bled, Slovenia), ENERGy Storage

K. Chen, L. Zhong, J. Lu, G. Wan \& Y. Luo: The Effect of Chloride Ions in Sn Doped $\mathrm{CuO}-\mathrm{CeO}_{2}$ Catalysts for Co Preferential Oxidation (CO-PROX) in $\mathrm{H}_{2}$-Rich Stream

detector (TCD). The $\mathrm{CO}$ conversion and $\mathrm{O}_{2}$ selectivity 2 were calculated based on the $\mathrm{CO}$ consumption[5].

\subsection{Catalyst characterization}

The specific surface areas were detected using a Brunauer-Emmett-Teller (BET) with nitrogen adsorption. Pore sizes distributions were got from the data of desorption branch by using Barrett-Joyner-Halenda (BJH) method. X-ray diffraction (XRD) patterns were performed using a Rigaku D/max-1200 diffractometer by using $\mathrm{Cu} \mathrm{K \alpha}$ radiation $\left(\lambda=1.5406 \AA\right.$ ) at $2 \theta$ range between 10 and $90^{\circ}$. X-ray photoelectron spectroscopy (XPS) was performed using a PHI 500 Versa Probe II analyzer employing non-monochromic $\mathrm{Al} \mathrm{K} \alpha$ radiation $(1486.6 \mathrm{eV})$. The $\mathrm{C} 1 \mathrm{~s}$ photoelectron peak at $284.6 \mathrm{eV}$ determined the binding energies as reference. Transmission electron microscopy (TEM) pictures were detected by using a JEOL JEM-2100 microscope with an accelerating voltage of $200 \mathrm{kV}$. Raman spectra was determined by a Via Reflex Confocal Raman Microscope with a laser $(514 \mathrm{~nm})$ working at $5 \mathrm{nV}$ power. $\mathrm{H}_{2}$ Temperature programmed reduction $\left(\mathrm{H}_{2} \mathrm{TPR}\right)$ measurement were performed in a fixed-bed reactor loading $0.1 \mathrm{~g}$ catalyst in a quartz tube. Catalysts were pretreated under a mixture gas $\left(10 \% \mathrm{H}_{2} / \mathrm{Ar}\right)$ at $100^{\circ} \mathrm{C}$ for $30 \mathrm{~min}$, then reduced by increasing the temperature at a rate of $10^{\circ} \mathrm{C} / \mathrm{min}$. Hydrogen consumption was monitored with a thermal conductivity detector (TCD).

\section{$3 \quad$ Results and Discussion}

\subsection{Effect of the ratio of $\mathrm{Sn}$ doped on $\mathrm{CuO}-\mathrm{CeO}_{2}$ catalyst}

\section{Catalytic activities}

As shown in Figure 1, the $\mathrm{CO}$ conversion and $\mathrm{O} 2$ selectivity over $\mathrm{Sn}(\mathrm{x})-\mathrm{CuCe}$ and $\mathrm{CuO}-$ $\mathrm{CeO} 2$. Obviously, when the temperature was below $140 \mathrm{oC}$ the $\mathrm{CO}$ conversion of the $\mathrm{Sn}(\mathrm{x})-\mathrm{CuCe}$ catalysts gradually increased with the molar ratio of $\mathrm{SnO} / \mathrm{CeO} 2$ increasing from 1 to 5\%. The conversion of $\mathrm{CO}$ was substantially decrease when furthering increasing the molar ratio of $\mathrm{SnO} / \mathrm{CeO} 2$ from 5 to $7.5 \%$. It can be seen that $\mathrm{CuO}-\mathrm{CeO} 2$ catalyst exhibited the highest $\mathrm{CO}$ conversion among the $\mathrm{Sn}$ doped in $\mathrm{CuO}-\mathrm{CeO} 2$ catalysts. When the reaction temperature was above $120 \mathrm{oC}$, the $\mathrm{O} 2$ selectivity of $\mathrm{Sn}(\mathrm{x})$ $\mathrm{CuCe}$ samples decreased by the water that formed from the oxidation of hydrogen. Furthermore, there were more thermodynamically favorable factors at high temperature[6]. 
$10^{\mathrm{TH}}$ International Conference on Sustainable Energy and Environmental Protection (June 27 $7^{\mathrm{TH}}-30^{\mathrm{TH}}, 2017$, Bled, SLovenia), Hydrogen ANd Fuel Cells K. Chen, L. Zhong, J. Lu, G. Wan \& Y. Luo: The Effect of Chloride Ions in Sn Doped $\mathrm{CuO}-\mathrm{CeO}_{2}$ Catalysts for Co Preferential Oxidation (CO-PROX) in $\mathrm{H}_{2}$-Rich Stream

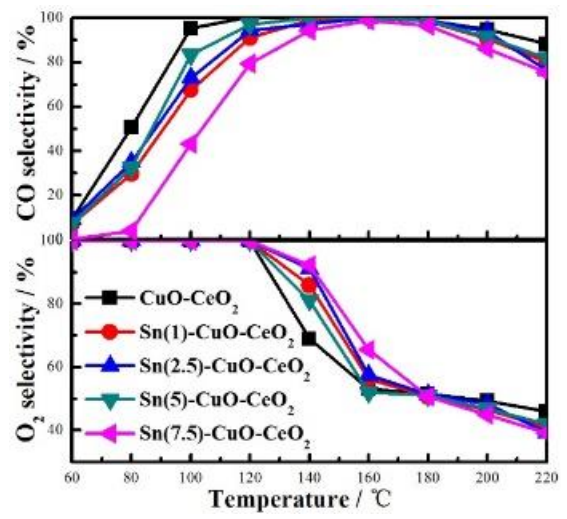

Figure $1 \mathrm{CO}$ conversion and $\mathrm{O}_{2}$ selectivity of $\mathrm{Sn}(\mathrm{x})-\mathrm{CuO}-\mathrm{CeO}_{2}$ and $\mathrm{CuO}-\mathrm{CeO}_{2}$

The catalytic activity of $\mathrm{Sn}(\mathrm{x})-\mathrm{CuCe}$ and $\mathrm{wSn}(\mathrm{x})-\mathrm{CuCe}$ for CO-PROX is shown in Figure 2. It was observed that all of catalytic activity of the $w \operatorname{Sn}(\mathrm{x})-\mathrm{CuCe}$ was superior to $\mathrm{Sn}(\mathrm{x})-$ $\mathrm{CuCe}$ and the reaction temperature window was broader than that of $\mathrm{Sn}(\mathrm{x})-\mathrm{CuCe}$, even much better than that of $\mathrm{CuO}-\mathrm{CeO}_{2}$ catalyst. It was suggested that the $\mathrm{Sn}$ doped into the $\mathrm{CuO}-\mathrm{CeO}_{2}$ catalyst improved the catalytic performance, and chloride ions indeed poison the catalysts. Remarkable improvement was observed for $\mathrm{wSn}(7.5)-\mathrm{CuCe}$ that contained the most amount of chloride ions on the surface. For instance, at $80^{\circ} \mathrm{C}$ the $\mathrm{CO}$ conversions of $\mathrm{Sn}(7.5)-\mathrm{CuCe}$ and $\mathrm{wSn}(7.5)-\mathrm{CuCe}$ were $3.96 \%$ and $61.77 \%$, respectively. In all of the samples, wSn(5)-CuCe being the highest $\mathrm{CO}$ conversion values catalyst which exhibited conversion values to $97.74 \%$ at $100^{\circ} \mathrm{C}$ and reached $100 \% \mathrm{CO}$ conversion at about $110^{\circ} \mathrm{C}$. The results obtained by catalytic tests indicate that chloride ions on the surface in the catalyst has a significant influence of the catalytic performance.

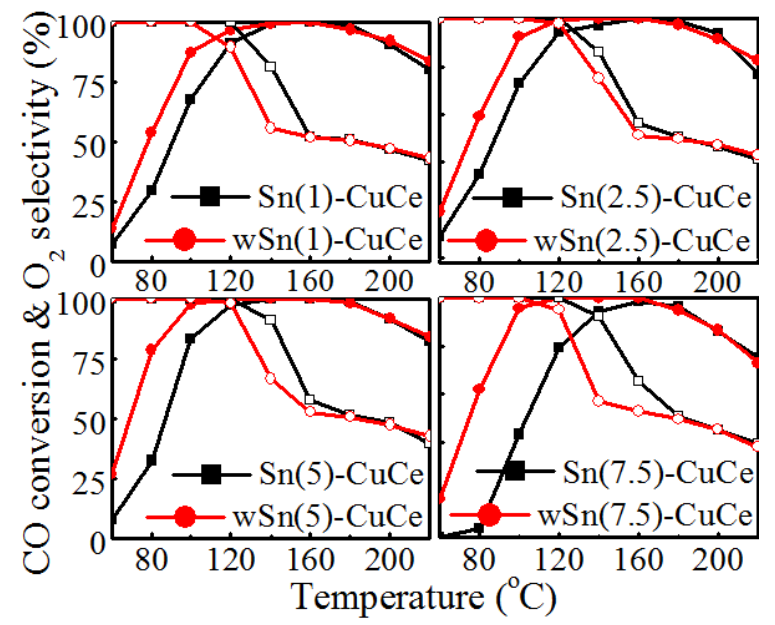

Figure 2. CO Conversion and $\mathrm{O} 2$ Selectivity of $\mathrm{Sn}(\mathrm{x})-\mathrm{CuCe}$ and $\mathrm{wSn}(\mathrm{x})-\mathrm{CuCe}$ 
$10^{\mathrm{TH}}$ INTERNATIONAL CONFERENCE ON SUSTAINABLE ENERGY AND ENVIRONMENTAL Protection (June $27^{\mathrm{TH}}-30^{\mathrm{TH}}, 2017$, Bled, SLOVEnia), EnERGy Storage

K. Chen, L. Zhong, J. Lu, G. Wan \& Y. Luo: The Effect of Chloride Ions in Sn Doped $\mathrm{CuO}-\mathrm{CeO}_{2}$ Catalysts for Co Preferential Oxidation (CO-PROX) in $\mathrm{H}_{2}$-Rich Stream

\section{$\mathbf{N}_{2}$-adsorption-desorption}

$\mathrm{N}_{2}$-adsorption-desorption measurement was used to investigate the influences of chloride ions on the textural properties of catalysts. The obtained values are collected in Table 1. It can be observed that after removing the chloride ions, $\mathrm{wSn}(\mathrm{x})-\mathrm{CuCe}$ possessed higher BET surface area which should be conductive to the dispersion of copper species and the formation of strong interaction between active copper species and support[7].

Table 1. Characteristics of Catalysts

\begin{tabular}{cccccc}
\hline Catalysts & $\begin{array}{c}\mathrm{S}_{\mathrm{BET}} \\
\left(\mathrm{m}^{2} / \mathrm{g}\right)\end{array}$ & $\begin{array}{c}\text { Pore } \\
\text { Diameter } \\
(\mathrm{nm})\end{array}$ & $\begin{array}{c}\text { Pore } \\
\text { Volume } \\
(\mathrm{cc} / \mathrm{g})\end{array}$ & $\begin{array}{c}\text { Lattice } \\
\text { parameter } \\
(\AA)\end{array}$ & $\begin{array}{c}\text { Crystallite size } \\
\text { of } \mathrm{CeO}_{2} \mathrm{~d}(111) \\
(\mathrm{nm})\end{array}$ \\
\hline $\mathrm{CuO-CeO} 2$ & 13.332 & 3.788 & 0.034 & 5.3996 & 17.08 \\
$\mathrm{Sn}(1)-\mathrm{CuCe}$ & 13.167 & 3.670 & 0.040 & 5.3913 & 16.79 \\
$\mathrm{Sn}(2.5)-\mathrm{CuCe}$ & 22.984 & 3.780 & 0.072 & 5.3885 & 15.65 \\
$\mathrm{Sn}(5)-\mathrm{CuCe}$ & 23.753 & 3.752 & 0.077 & 5.3887 & 15.02 \\
$\mathrm{Sn}(7.5)-\mathrm{CuCe}$ & 19.188 & 3.377 & 0.061 & 5.3847 & 13.25 \\
wSn(1)-CuCe & 29.308 & 3.357 & 0.061 & 5.3911 & 16.36 \\
wSn(2.5)-CuCe 36.117 & 3.368 & 0.082 & 5.3885 & 15.68 \\
wSn(5)-CuCe & 51.839 & 3.349 & 0.116 & 5.3822 & 13.50 \\
wSn(7.5)-CuCe 42.765 & 3.371 & 0.093 & 5.3773 & 13.23 \\
\hline
\end{tabular}

\section{XRD}

Figure 4. shows the XRD patterns of $\mathrm{Sn}(\mathrm{x})-\mathrm{CuCe}$ and $\mathrm{wSn}(\mathrm{x})-\mathrm{CuCe}$ with various $\mathrm{SnO}$ loadings. As same as the $\mathrm{Sn}(\mathrm{x})-\mathrm{CuCe}$, in the XRD patterns the diffraction peaks of all the catalysts were assigned to the cubic fluorite structure of $\mathrm{CeO} 2$, and there is no extra diffraction peaks of $\mathrm{SnO}$ or $\mathrm{CuO}$ species detected from the each of them, implying that the low content of tin or copper species have been highly incorporated into the ceria lattice to form a solid solution[8]. When the $\mathrm{Sn}$ was loaded into $\mathrm{CuO}-\mathrm{CeO} 2$ catalyst, the peaks became broader, indicating that the particle sizes of $\mathrm{Sn}(\mathrm{x})-\mathrm{CuCe}(\mathrm{x}>0)$ catalysts became smaller, due to the ionic radius of Sn4+ $(0.81 \AA)$ is smaller than that of Ce4+ $(0.97 \AA)$, further preventing that all of $\mathrm{SnO} 2$ is incorporated into the cell of $\mathrm{CeO} 2[9]$. By contrast, the reflection peaks of $\mathrm{wSn}(\mathrm{x})-\mathrm{CuCe}$ were shifted to the low-angle region and also broader than those of $\mathrm{Sn}(\mathrm{x})-\mathrm{CuCe}$, suggesting that the decrease of crystallinity formed in $\mathrm{wSn}(\mathrm{x})-\mathrm{CuCe}$. As described in previous work[10], even extremely small amounts of chloride provided the necessary species for a sintering mechanism of $\mathrm{Cu}$ via surface migration. This is probably because of a synergetic effect in $\mathrm{Cu}-\mathrm{Cl}$ mixed compound may cause bulk $\mathrm{CuCl} 2$ during preparation procedure through the surface migration and further caused high crystallinity and decay of $\mathrm{CO}$ conversion. 
$10^{\mathrm{TH}}$ International Conference on Sustainable Energy and Environmental Protection (June 27 $7^{\mathrm{TH}}-30^{\mathrm{TH}}, 2017$, Bled, SLovenia), Hydrogen ANd Fuel Cells K. Chen, L. Zhong, J. Lu, G. Wan \& Y. Luo: The Effect of Chloride Ions in Sn Doped $\mathrm{CuO}-\mathrm{CeO}_{2}$ Catalysts for Co Preferential Oxidation (CO-PROX) in $\mathrm{H}_{2}$-Rich Stream

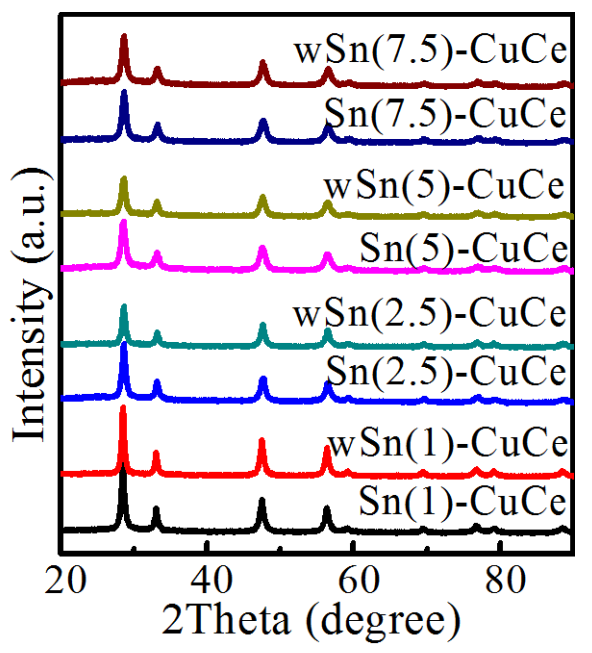

Figure 4. XRD Patterns $\mathrm{Sn}(\mathrm{x})-\mathrm{CuCe}$ and $\mathrm{wSn}(\mathrm{x})-\mathrm{CuCe}$

\section{$\mathbf{H}_{2}$-TPR}

$\mathrm{H}_{2}$-TPR profiles of all catalysts are displayed in Figure 5. For each catalyst, the reduction peak at about $185^{\circ} \mathrm{C}$ ( $\alpha$ peak) is attributed to the reduction of small particle $\mathrm{CuO}$ presenting as finely dispersed particles[11]. The reduction peak at $222^{\circ} \mathrm{C}$ ( $\beta$ peak) is assigned to medium particle of $\mathrm{Cu}^{2+}$ ions entered in the lattices of $\mathrm{CeO}_{2}$ solid solution, and the reduction $\gamma$ peak at about $270^{\circ} \mathrm{C}$ corresponds to the reduction of bulk $\mathrm{Cu}$ species[12]. After made $\mathrm{H}_{2}$-TPR experiment on $\mathrm{CuCl}_{2}-\mathrm{CuCe}$ catalysts we confirmed that the $\gamma$ peak was corresponding to the dispersed $\mathrm{CuCl}_{2}$ species into the $\mathrm{CeO}_{2}$ support (As shown in Figure $\mathrm{S} 1$ ). Comparing the $\mathrm{H}_{2}$-TPR profile of $\mathrm{Sn}(\mathrm{x})-\mathrm{CuCe}$ catalysts, it was noted that the $\gamma$ peak of $\mathrm{wSn}(\mathrm{x})-\mathrm{CuCe}$ disappeared and shifted to a stronger $\beta$ peak, indicating that in $\mathrm{wSn}(\mathrm{x})-\mathrm{CuCe}$ copper chloride has been reduced to $\mathrm{Cu}^{2+}$ ions. This result directly promote a consequence of that the metal dispersion entered in the lattices of $\mathrm{CeO}_{2}$, promoting a strong interaction between the copper and ceria[13]. Obviously, the temperature of $\beta$ peak shifted to a lower temperature and its $\mathrm{H}_{2}$ consumption substantially increased in $\mathrm{wSn}(5)-\mathrm{CuCe}$ catalyst. It is significant for understanding the catalytic performance for being the highest activity value. 
$10^{\mathrm{TH}}$ INTERNATIONAL CONFERENCE ON SUSTAINABLE ENERGY AND ENVIRONMENTAL Protection (June $27^{\mathrm{TH}}-30^{\mathrm{TH}}, 2017$, Bled, SLOVEnia), EnERGy Storage

K. Chen, L. Zhong, J. Lu, G. Wan \& Y. Luo: The Effect of Chloride Ions in Sn Doped $\mathrm{CuO}-\mathrm{CeO}_{2}$ Catalysts for Co Preferential Oxidation (CO-PROX) in $\mathrm{H}_{2}$-Rich Stream

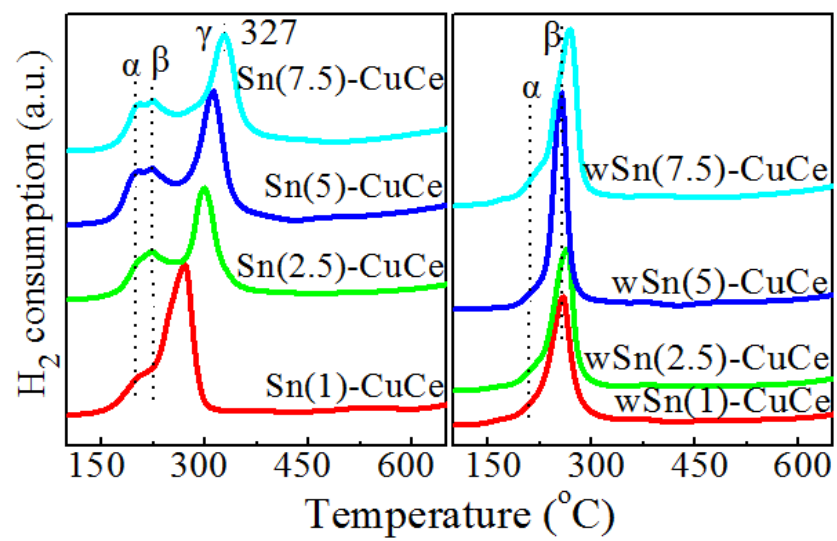

Figure 5. $\mathrm{H}_{2}$-TPR Profiles of $\mathrm{Sn}(\mathrm{x})-\mathrm{CuCe}$ and $\mathrm{wSn}(\mathrm{x})-\mathrm{CuCe}$

\section{XPS}

The XPS analysis of $\mathrm{Sn}(5)-\mathrm{CuCe}$ and $\mathrm{wSn}(5)-\mathrm{CuCe}$ was displayed in Figure 6, where the $\mathrm{Ce} 3 \mathrm{~d}, \mathrm{Sn} 3 \mathrm{~d}, \mathrm{O} 1 \mathrm{~s}$ and $\mathrm{Cu} 2 \mathrm{p}$ core level spectra have been depicted to determine the corresponding species presented on their surface.

The core level photoelectron spectrum of Ce $3 \mathrm{~d}$ can be fitted by eight peaks [14]. As shown in Figure 6(A), the peaks labeled as v, v', v',', u, u', and u' ', have been attributed to $\mathrm{Ce}^{4+}$ state as in $\mathrm{CeO}_{2}$, and the peaks marked as $\mathrm{v}^{\prime}$ and $\mathrm{u}^{\prime}$ are corresponding to $\mathrm{Ce}^{3+}$ species[15], indicating that the surface of the $\mathrm{CeO}_{2}$ substrate is not fully oxidized and contains some oxygen vacancies.

Table 2. XPS Results

\begin{tabular}{cccccccc}
\hline \multirow{2}{*}{ Catalysts } & \multicolumn{3}{c}{ Binding energy (eV) } & $\mathrm{Ce}_{3+} / \mathrm{Ce}_{4+} \mathrm{Sn}_{+2} / \mathrm{Sn}_{+4} \mathrm{I}_{\text {sat }} / \mathrm{I}_{\text {mp }} \mathrm{O}_{\text {II }} / \mathrm{O}_{\mathrm{I}}+\mathrm{O}_{\mathrm{II}}$ \\
& $\mathrm{Ce} 3 \mathrm{~d}_{5 / 2} \mathrm{Sn} 3 \mathrm{~d}_{5 / 2} \mathrm{Cu} 2 \mathrm{p}_{3 / 2}$ & & & \\
\hline $\mathrm{Sn}(5)-\mathrm{CuCe}$ & 882.9 & 486.3 & 933.4 & 0.070 & 1.22 & 0.26 & 0.458 \\
$\mathrm{wSn}(5)-\mathrm{CuCe}$ & 882.6 & 486.3 & 933.9 & 0.073 & 1.31 & 0.37 & 0.456 \\
\hline
\end{tabular}

The XPS spectra of $\mathrm{Sn} 3 \mathrm{~d}_{5 / 2}$ and $\mathrm{Sn} 3 \mathrm{~d}_{3 / 2}$ is shown in Figure 6(B). For the tin-containing in two samples, two distinguished peaks centered at $486.5 \mathrm{eV}$ assigned to $\mathrm{Sn} 3 \mathrm{~d}_{5 / 2}$ and another one centered at $495.0 \mathrm{eV}$ was corresponding to the $S n 3 \mathrm{~d}_{3 / 2}[16]$, namely with the presence of species of $\mathrm{Sn}^{4+}$. The O 1s XPS spectra is also shown in Figure 6(C). There is a main peak centered at $531.0 \mathrm{eV}$ which attributed to the lattice oxygen on the surface, accompanying with the main peak is a shoulder peak approximately at $529.2 \mathrm{eV}$, which is attributed to the chemisorbed oxygen on the surface[17]. Figure 6(D) shows Cu core level 2 p spectra, It can be observed that both two catalysts showed two sets of peaks at $932.7 \mathrm{eV}$ and $952.5 \mathrm{eV}$, which attributed to $\mathrm{Cu} 2 \mathrm{p} 3 / 2$ and $2 \mathrm{p} 1 / 2$ transitions, respectively[14]. The higher binding energy (centered at $933.2 \mathrm{eV}$ ) for the $\mathrm{Cu} 2 \mathrm{p}_{3 / 2}$ peak and the existence of the shake-up peak which is a fingerprint of $\mathrm{Cu}^{2+}$, whereas lower 
$10^{\text {TH }}$ International Conference on Sustainable Energy and Environmental Protection (June 27 $7^{\mathrm{TH}}-30^{\mathrm{TH}}, 2017$, Bled, SLovenia), Hydrogen ANd Fuel Cells K. Chen, L. Zhong, J. Lu, G. Wan \& Y. Luo: The Effect of Chloride Ions in Sn Doped $\mathrm{CuO}-\mathrm{CeO}_{2}$ Catalysts for Co Preferential Oxidation (CO-PROX) in $\mathrm{H}_{2}$-Rich Stream

binding energy (centered at $934.9 \mathrm{eV}$ ) for the $\mathrm{Cu} 2 \mathrm{p}_{3 / 2}$ peak together with the presence of the shake-up peak are the features of $\mathrm{Cu}^{+}[18]$, indicating that $\mathrm{Cu}^{+}$and $\mathrm{Cu}^{2+}$ species are coexisted on their surface[19]. Table 2 listed the relative intensity of satellite with respect to main photoelectron peak $\left(\mathrm{I}_{\mathrm{sat}} / \mathrm{I}_{\mathrm{mp}}\right)$ to further investigate the valence of copper in these two samples. The $\mathrm{I}_{\mathrm{sat}} / \mathrm{I}_{\mathrm{mp}}$ of $\mathrm{wSn}(5)-\mathrm{CuCe}$ is higher than that of $\mathrm{Sn}(5)-\mathrm{CuCe}$, suggesting the presence of more $\mathrm{Cu}^{2+}$ in $\mathrm{wSn}(5)-\mathrm{CuCe}$ that would be entered in the lattices of $\mathrm{CeO}_{2}$, which is in favor of the $\mathrm{H}_{2}$-TPR results.

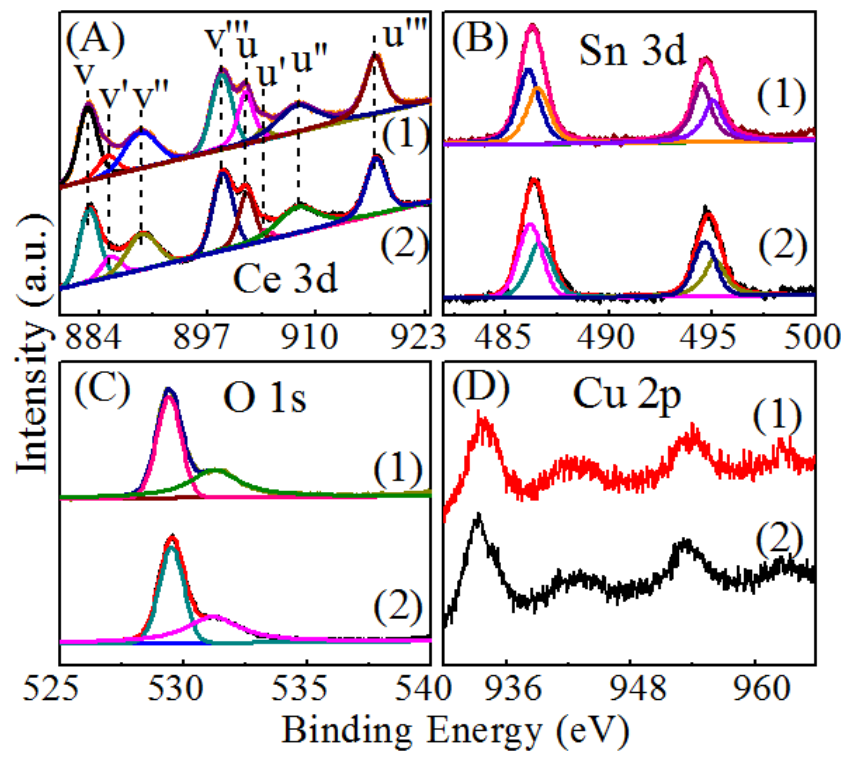

Figure 6. XPS Spectra (A) Ce 3d (B) Sn 3d (C) O 1s (D) Cu 2p of Sn(5)-CuCe and wSn(5)-CuCe

\section{Raman Spectroscopy}

The Raman spectra of $\mathrm{Sn}(7.5)-\mathrm{CuCe}$ and $w \mathrm{Sn}(7.5)-\mathrm{CuCe}$ are presented in Figure 7. All the samples showed a main band around $458 \mathrm{~cm}^{-1}$ that is a characteristic of the cubic fluorite structure of $\mathrm{CeO}_{2}$ [20]. It is shifted to lower frequencies and broadened while removing the chloride on the surface of the $\mathrm{Sn}(7.5)$-CuCe. These observations can be explained by combining effects of inhomogeneous strain and phonon confinement related to the presence of reduced states of cerium and smaller $\mathrm{CeO}_{2}$ units[22]. Besides, a broad peak at ca. $598 \mathrm{~cm}^{-1}$ has been attributed to the oxygen vacancies[21]. The Raman results are in good agreement with $\mathrm{H}_{2}$-TPR and XRD analysis on the effect of chloride on the catalysts surface. 
$10^{\mathrm{TH}}$ INTERNATIONAL CONFERENCE ON SUSTAINABLE ENERGY AND ENVIRONMENTAL Protection (June $27^{\mathrm{TH}}-30^{\mathrm{TH}}, 2017$, Bled, SLOVEnia), EnERGy Storage

K. Chen, L. Zhong, J. Lu, G. Wan \& Y. Luo: The Effect of Chloride Ions in Sn Doped $\mathrm{CuO}-\mathrm{CeO}_{2}$ Catalysts for Co Preferential Oxidation (CO-PROX) in $\mathrm{H}_{2}$-Rich Stream

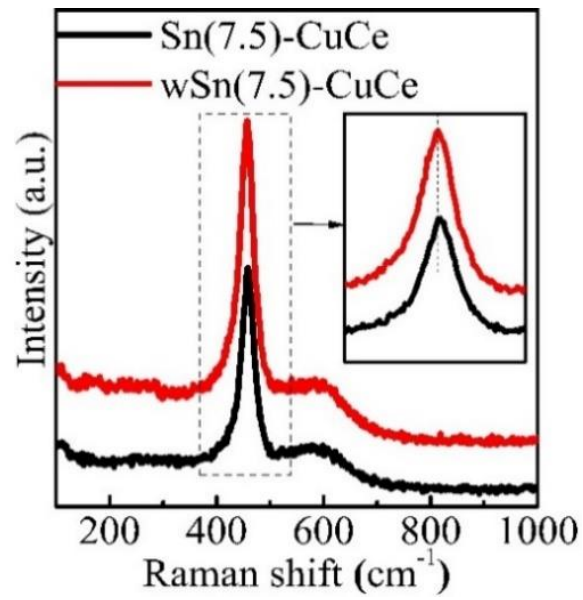

Figure 7. Raman Spectra of $\mathrm{Sn}(7.5)-\mathrm{CuCe}$ and $\mathrm{wSn}(7.5)-\mathrm{CuCe}$

\section{Conclusions}

In summary, a series of Sn-doped $\mathrm{CuO}-\mathrm{CeO}_{2}$ catalysts were synthesized rapidly within 30 minutes with a facile and solvent-free route, the $\mathrm{Sn}(\mathrm{x})-\mathrm{CuO}-\mathrm{CeO}_{2}$ samples were characterized by XRD, HR-TEM and $\mathrm{H}_{2}$-TPR. The results showed that the $\mathrm{Sn}(\mathrm{x})-\mathrm{CuO}-$ $\mathrm{CeO}_{2}$ have lower $\mathrm{CO}$ conversion for $\mathrm{CO}-\mathrm{PROX}$ than that of $\mathrm{CuO}-\mathrm{CeO}_{2}$ owing to the chloride ions which came from precursor combined with metal ions and further cause high crystallinity and decrease of $\mathrm{CO}$ conversion. Thus, the catalysts without chloride ions ( $\mathrm{wSn}(\mathrm{x})-\mathrm{CuO}-\mathrm{CeO}_{2}$ ) were prepared. $\mathrm{N}_{2}$-adsorption-desorption, XRD, XPS, $\mathrm{H}_{2}$-TPR and Raman experiments were measured to investigate the influence of chloride ions on the catalyst surface and catalytic performance. The $\mathrm{wSn}(\mathrm{x})-\mathrm{CuO}-\mathrm{CeO}_{2}$ were superior to the $\mathrm{Sn}(\mathrm{x})-\mathrm{CuO}-\mathrm{CeO}_{2}$ and $\mathrm{CuO}-\mathrm{CeO}_{2}, \quad w \mathrm{Sn}(5)-\mathrm{CuO}-\mathrm{CeO}_{2}$ being the highest $\mathrm{CO}$ conversion value which exhibited conversion values to $97.78 \%$ at $100^{\circ} \mathrm{C}$. It was attributed to the higher surface area, more $\mathrm{Cu}^{2+}$ ions entered into the lattices of $\mathrm{CeO}_{2}$, more reduced copper species and the decrease of crystallinity for catalysts. From these results, the controlling factor for the $\mathrm{CO}$ conversion in CO-PROX should be the absence of chloride ions on the catalysts surface.

\section{Acknowledgements}

We gratefully acknowledge the financial supports of the National Natural Science Foundation of China (Grant Nos. U1402233, 21267011 and 21367015).

\section{References}

[1] N. Hammer, K. Mathisen, T. Zscherpe, D. Chen, and M. Rønning, "Effect of Pretreatment on Carbon-Supported $\mathrm{Au} / \mathrm{TiO} 2$ Catalysts for Preferential Oxidation of $\mathrm{CO}$," Topics in Catalysis, vol. 54, pp. 922-930, 2011. 
$10^{\mathrm{TH}}$ International CONFEREnce on Sustainable Energy and Environmental Protection (June 27 $7^{\mathrm{TH}}-30^{\mathrm{TH}}, 2017$, Bled, SLovenia), Hydrogen ANd Fuel Cells K. Chen, L. Zhong, J. Lu, G. Wan \& Y. Luo: The Effect of Chloride Ions in Sn Doped $\mathrm{CuO}-\mathrm{CeO}_{2}$ Catalysts for Co Preferential Oxidation (CO-PROX) in $\mathrm{H}_{2}$-Rich Stream

[2] D. Gamarra and A. Martínez-Arias, "Preferential oxidation of $\mathrm{CO}$ in rich $\mathrm{H} 2$ over $\mathrm{CuO} / \mathrm{CeO} 2$ : Operando-DRIFTS analysis of deactivating effect of $\mathrm{CO} 2$ and $\mathrm{H} 2 \mathrm{O}$," Journal of Catalysis, vol. 263, pp. 189-195, 2009.

[3] S. Wang, J. Huang, Y. Zhao, S. Wang, X. Wang, T. Zhang, et al., "Preparation, characterization and catalytic behavior of $\mathrm{SnO} 2$ supported Au catalysts for low-temperature CO oxidation," Journal of Molecular Catalysis A: Chemical, vol. 259, pp. 245-252, 2006.

[4] M. Kong, Q. Liu, L. Jiang, F. Guo, S. Ren, L. Yao, et al., "Property influence and poisoning mechanism of $\mathrm{HgCl} 2$ on V2O5-WO3/TiO2 SCR-DeNOx catalysts," Catalysis Communications, vol. 85, pp. 34-38, 2016.

[5] J. Wang, L. Deng, D. He, J. Lu, S. He, S. He, et al., "A facile and rapid route to synthesize $\mathrm{CuOx} / \mathrm{Ce} 0.8 \mathrm{Zr} 0.2 \mathrm{O} 2$ catalysts with high performance for $\mathrm{CO}$ preferential oxidation (COPROX)," International Journal of Hydrogen Energy, vol. 40, pp. 12478-12488, 2015.

[6] A. A.-D. Álvaro Reyes-Carmona, Elisa Moretti, Aldo Talon, Loretta Storaro,Maurizio Lenarda, Antonio Jiménez-L ópez, Enrique Rodríguez-Castellón, "CuO/CeO2 supported on $\mathrm{Zr}$ doped SBA-15 as catalysts for preferential CO oxidation (CO-PROX)," Journal of Power Sources, vol. 196, pp. 4382-4387, 2011.

[7] J. Wang, C. Han, X. Gao, J. Lu, G. Wan, D. He, et al., "Rapid synthesis of Fe-doped CuO$\mathrm{Ce} 0.8 \mathrm{Zr} 0.2 \mathrm{O} 2$ catalysts for $\mathrm{CO}$ preferential oxidation in $\mathrm{H} 2$-rich streams: Effect of iron source and the ratio of Fe/Cu," Journal of Power Sources, vol. 343, pp. 437-445, 3/1/ 2017.

[8] D. He, G. Wan, H. Hao, D. Chen, J. Lu, L. Zhang, et al., "Microware-assisted rapid synthesis of $\mathrm{CeO} 2$ nanoparticles and its desulfurization processes for $\mathrm{CH} 3 \mathrm{SH}$ catalytic decomposition," Chemical Engineering Journal, vol. 289, pp. 161-169, 2016.

[9] A. Iglesias-González, J. L. Ayastuy, M. P. González-Marcos, and M. A. Gutiérrez-Ortiz, " $\mathrm{CuO} / \mathrm{CexSn} 1-\mathrm{xO} 2$ catalysts with low tin content for $\mathrm{CO}$ removal from H2-rich streams," International Journal of Hydrogen Energy, vol. 39, pp. 5213-5224, 2014.

[10] S. Zeng, K. Liu, L. Zhang, B. Qin, T. Chen, Y. Yin, et al., "Deactivation analyses of $\mathrm{CeO} 2 / \mathrm{CuO}$ catalysts in the preferential oxidation of carbon monoxide," Journal of Power Sources, vol. 261, pp. 46-54, 2014.

[11] T. d. F. S. Cristhiane Guimarães Maciel, Luciene Paula Roberto Profeti, Elisabete Moreira Assaf, José Mansur Assaf, "Study of $\mathrm{CuO} / \mathrm{CeO} 2$ catalyst with for preferential CO oxidation reaction in hydrogen-rich feed (PROX-CO)," Applied Catalysis A: General, vol. 431-432, pp. 25-32, 2012.

[12] Z. Wu, H. Zhu, Z. Qin, H. Wang, J. Ding, L. Huang, et al., "CO preferential oxidation in $\mathrm{H} 2$-rich stream over a $\mathrm{CuO} / \mathrm{CeO} 2$ catalyst with high $\mathrm{H} 2 \mathrm{O}$ and $\mathrm{CO} 2$ tolerance," Fuel, vol. 104, pp. 41-45, 2013.

[13] C. G. Maciel, T. d. F. Silva, M. I. Hirooka, M. N. Belgacem, and J. M. Assaf, "Effect of nature of ceria support in $\mathrm{CuO} / \mathrm{CeO} 2$ catalyst for PROX-CO reaction," Fuel, vol. 97, pp. 245-252, 2012.

[14] Y. Luo, R. Chen, W. Peng, G. Tang, X. Gao, "Inverse CeO2-Fe2O3 catalyst for superior low-temperature CO conversion efficiency," Applied Surface Science, vol. 416, pp. 911 917, 2017.

[15] Y. Liu, B. Liu, Q. Wang, C. Li, W. Hu, Y. Liu, et al., "Three-dimensionally ordered macroporous $\mathrm{Au} / \mathrm{CeO} 2-\mathrm{Co} 3 \mathrm{O} 4$ catalysts with mesoporous walls for enhanced $\mathrm{CO}$ preferential oxidation in H2-rich gases," Journal of Catalysis, vol. 296, pp. 65-76, 2012.

[16] K. Li, Y. Wang, S. Wang, B. Zhu, S. Zhang, W. Huang, et al., "A comparative study of $\mathrm{CuO} / \mathrm{TiO} 2-\mathrm{SnO} 2, \mathrm{CuO} / \mathrm{TiO} 2$ and $\mathrm{CuO} / \mathrm{SnO} 2$ catalysts for low-temperature $\mathrm{CO}$ oxidation," Journal of Natural Gas Chemistry, vol. 18, pp. 449-452, 2009.

[17] J.-L. Cao, Y. Wang, T.-Y. Zhang, S.-H. Wu, and Z.-Y. Yuan, "Preparation, characterization and catalytic behavior of nanostructured mesoporous $\mathrm{CuO} / \mathrm{Ce} 0.8 \mathrm{Zr} 0.2 \mathrm{O} 2$ catalysts for low- 
$10^{\mathrm{TH}}$ INTERNATIONAL CONFERENCE ON SUSTAINABLE ENERGY AND ENVIRONMENTAL

K. Chen, L. Zhong, J. Lu, G. Wan \& Y. Luo: The Effect of Chloride Ions in Sn Doped

$\mathrm{CuO}-\mathrm{CeO}_{2}$ Catalysts for Co Preferential Oxidation (CO-PROX) in $\mathrm{H}_{2}$-Rich Stream

temperature CO oxidation," Applied Catalysis B: Environmental, vol. 78, pp. 120-128, 2008.

[18] S. Zeng, X. Bai, X. Wang, W. Yu, and Y. Liu, "Valence State of Active Copper in $\mathrm{CuOx} / \mathrm{CeO} 2$ Catalysts for CO Oxidation," Journal of Rare Earths, vol. 24, pp. 177-181, 2006.

[19] L. S. Elisa Moretti, Aldo Talon, Maurizio Lenarda, Piero Riello, Romana Frattini,María del Valle Martínez de Yuso, Antonio Jiménez-López, Enrique Rodríguez-Castellón, Fátima Ternero, Alfonso Caballero, Juan P. Holgado, "Effect of thermal treatments on the catalytic behaviour in the $\mathrm{CO}$ preferential oxidation of a $\mathrm{CuO}-\mathrm{CeO} 2-\mathrm{ZrO} 2$ catalyst with a flowerlike morphology," Applied Catalysis B: Environmental, vol. 102, pp. 627-637, 2011.

[20] F. Liu, D. He, J. Lu, D. Chen, P. Liu, J. Yu, et al., "A facile and rapid route to synthesize ceria-zircoa nanoparticles with high performance for $\mathrm{CH} 3 \mathrm{CH}$ decomposition" Materials Rearch Bulletin, vol. 93, pp. 150-156, 2017.

[21] X.-S. L. Zhi-Ying Pu, Ai-Ping Jia, Yun-Long Xie, Ji-Qing Lu, and Meng-Fei Luo, "Enhanced Activity for CO Oxidation over Pr- and Cu-Doped CeO2 Catalysts: Effect of Oxygen Vacancies," J. Phys. Chem. C, vol. 112, pp. 15045-15051, 2008 
$140 \quad 10^{\mathrm{TH}}$ International Conference on Sustainable EnERgy and EnVIRONMENTAL Protection (June 27 $7^{\mathrm{TH}}-30^{\mathrm{TH}}, 2017$, Bled, Slovenia), Hydrogen And Fuel Cells 
$10^{\mathrm{TH}}$ InTERnAtional CONFERENCE ON Sustainable ENERgy AND ENVIRONMENTAL Protection (June $27^{\mathrm{TH}}-30^{\mathrm{TH}}$, 2017, Bled, Slovenia), Hydrogen ANd Fuel Cells

J. Krope, A.Ghani Olabi, D. Goričanec \& S. Božičnik

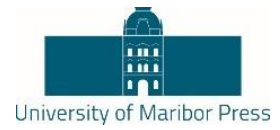

\title{
Design and Testing of a Single-Cell PEM Electrolyser for Small-Scale Hydrogen Production Under Mild Conditions
}

\author{
Antonio L. Tomas-Garcia, Mojtaba Mirzaeian, Greig Chisholm \& Abdul G. \\ OLABI
}

\begin{abstract}
Single-cell PEM electrolysers for small-scale hydrogen production in mild conditions were designed, built and tested at $40^{\circ} \mathrm{C}$ and 6.9 barg $\mathrm{H}_{2}$ differential pressure. The effect of membrane material, catalyst loading, and clamping pressure was studied for different cells, with the use of i-V curves, impedance spectroscopy, and gas crossover estimation. It was found that membrane selection and clamping pressure applied through bolt loading was more important than the effect of catalyst loading in either anode or cathode for cell performance, under the studied conditions.
\end{abstract}

Keywords: • PEM • electrolysis $・$ design $\bullet$ hydrogen generation $\bullet$ mild conditions $\bullet$

CORRESPONDENCE ADDRESS: Antonio L. Tomas-Garcia, University of the West of Scotland, School of Engineering and Computing, High St, Paisley PA1 2BE United Kingdom, email: antonio.tomasgarcia@uws.ac.uk. Mojtaba Mirzaeian, University of the West of Scotland, School of Engineering and Computing, , High St, Paisley PA1 2BE United Kingdom, email: mojtaba.mirzaeian@uws.ac.uk. Greig Chisholm, Peak Scientific Instruments Ltd, Fountain Crescent, Inchinnan Business Park, Inchinnan PA4 9RE, United Kingdom: email: gchisholm@peakscientific.com. Abdul G. Olabi, University of the West of Scotland, School of Engineering and Computing, High St, Paisley PA1 2BE, United Kingdom, email: abdul.olabi@uws.ac.uk. 
$10^{\mathrm{TH}}$ International Conference on Sustainable EnERgy AND ENVIRONMENTAL Protection (June $27^{\mathrm{TH}}-30^{\mathrm{TH}}, 2017$, Bled, Slovenia), Hydrogen and Fuel Cells A. L. Tomas-Garcia, M. Mirzaeian, G Chisholm \& A. G.Olabi: Design and Testing of a Single-Cell PEM Electrolyser for Small-Scale Hydrogen Production Under Mild Conditions

\section{$1 \quad$ Introduction}

Polymer electrolyte membrane (PEM) fuel cells and electrolysers are widely proposed for energy conversion through the use of hydrogen as fuel[1]. In this context, PEM electrolysis provides an alternative to more traditional alkaline electrolysis systems, with cells that tend to be more compact, efficient, with higher gas purity and the possibility of differential pressurization[2]. These characteristics make PEM electrolysers ideal for onsite generation of pressurized, high-purity hydrogen and oxygen.

Perfluorosulfonic acid (PFSA) based cells usually show their highest energy efficiency in the $70-90{ }^{\circ} \mathrm{C}$ temperature range and atmospheric gas pressures, due to catalyst and membrane properties[1], [3]; this range is therefore recommended for applications such as off-grid electric power storage. However, in cases where cell durability and gas purity are more important, like carrier gas for chromatography applications[4], it might be more convenient to work at lower temperatures. While most published research deals with cell performance at the aforementioned higher temperatures, less work is done yet on cell design for low temperature applications.

In this work, we studied the influence of design aspects such as: choice of membrane, catalyst loading, and clamping bolt torque on the performance of PEM cells operating at $40{ }^{\circ} \mathrm{C}$ and 6.9 barg $\mathrm{H}_{2}$ differential pressure.

\section{Experimental}

\subsection{Design concept}

A series of single-cell PEM electrolysers were designed, based on the flanged reactor principle, used in most commercial systems. Figure 1 shows a schematic diagram of the cell design. The cell consists of 5 main layers: a Catalyst Coated Membrane (CCM), anode GDL subassembly made of porous titanium, cathode GDL subassembly made of porous graphitized carbon, and stainless steel plates. 
A. L. Tomas-Garcia, M. Mirzaeian, G Chisholm \& A. G.Olabi: Design and Testing of a Single-Cell PEM Electrolyser for Small-Scale Hydrogen Production Under Mild Conditions

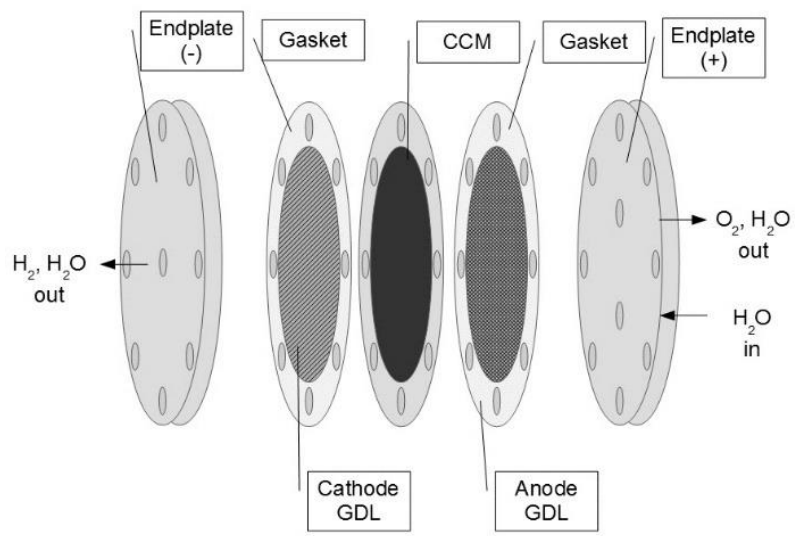

Figure 1. Diagram of the electrolyser design.

The active section was circular, with $23.8 \mathrm{~cm}^{2}$ geometric area. The design current was set at $26.8 \mathrm{~A}$, for a nominal hydrogen production capacity of $200 \mathrm{~mL} / \mathrm{min}(1 \mathrm{bar}, 293 \mathrm{~K})$.

\section{Construction materials}

Perfluorosulfonic acid (PFSA) type membranes were used in the CCMs, purchased from two commercial suppliers. Two PFSA-based membranes, with and without a fibre reinforcement, were purchased from Supplier A. In addition, a series of Nafion ${ }^{\circledR} 115$ based CCMs were purchased, with different loadings of $40 \% \mathrm{Pt} /$ carbon (cathode) and Ir black (anode), from Supplier B. Table 1 shows the main characteristics for the different cell configurations. The descriptor code for each CCM is $\{$ Membrane $\}-\{\mathrm{Pt}$ loading, $\left.\mathrm{mg} \cdot \mathrm{cm}^{-2}\right\}-\left\{\right.$ Ir loading, $\left.\mathrm{mg} \cdot \mathrm{cm}^{-2}\right\}$.

The cell had 8 bolts distributed symmetrically around the cell active area. In order to control cell clamping pressure, known torque was applied upon assembly with a torque wrench.

Table 1. Tested cell configurations.

\begin{tabular}{|l|l|l|}
\hline Cell ID & CCM configuration & $\begin{array}{l}\text { Torque/ } \\
\mathrm{N} \cdot \mathrm{m}\end{array}$ \\
\hline A-5 & N115-Pt1-Ir2 & 5 \\
\hline A-10 & N115-Pt1-Ir2 & 10 \\
\hline A & N115-Pt1-Ir2 & 15 \\
\hline B & N115-Pt1-Ir1 & 15 \\
\hline C & N115-Pt0.5-Ir1 & 15 \\
\hline D & PFSA-Pt0.65-Ir2.2 & 15 \\
\hline E & PFSA-Pt0.65-Ir2.2-R & 15 \\
\hline
\end{tabular}


$14410^{\mathrm{TH}}$ InTERnational CONFERENCE ON Sustainable ENERGy AND ENVIRONMENTAL Protection (June $27^{\mathrm{TH}}-30^{\mathrm{TH}}, 2017$, Bled, Slovenia), Hydrogen and Fuel Cells A. L. Tomas-Garcia, M. Mirzaeian, G Chisholm \& A. G.Olabi: Design and Testing of a Single-Cell PEM Electrolyser for Small-Scale Hydrogen Production Under Mild Conditions

\subsection{Performance testing}

The electrochemical evaluation of the different cell configurations was done in an inhouse built setup, with hydrogen chamber pressure, water temperature and water flow control. A Bio-logic HCP-1005 boosted potentiostat was used for the electrochemical measurements. Cell performance was measured with $\mathrm{i}-\mathrm{V}$ curves and Electrochemical Impedance Spectroscopy (EIS).

For cell performance evaluation, all experiments were carried out at $40^{\circ} \mathrm{C}$ and differential $\mathrm{H}_{2}$ pressure of $6.9 \mathrm{barg}$, with atmospheric $\mathrm{O}_{2}$ pressure. A peristaltic pump was used to push water through the setup, from a water reservoir with constant temperature control, through an ion exchange column, into the anode chamber of the cell, and back into the water reservoir; water pumping rate was kept constant at $150 \mathrm{~mL} / \mathrm{min}$.

Cells were run at constant 26.8 A current for $48 \mathrm{~h}$, before obtaining i-V curves and EIS spectra measurements. EIS spectra were obtained at $100 \mathrm{cmA} \cdot \mathrm{m}^{-2}$, from $10 \mathrm{kHz}$ to $50 \mathrm{mHz}$, with 6 points per decade measured and $10 \mathrm{~mA} \cdot \mathrm{cm}^{-2} \mathrm{rms} \mathrm{AC} \mathrm{signal.} \mathrm{From} \mathrm{these,}$ the ohmic resistance was taken as the real component at zero imaginary component. The cell area specific resistance (ASR) was calculated by normalizing ohmic resistance to electrode geometric active area. Gas crossover was estimated indirectly following a method described by Schalenbach et al. [5], using pressure build-up in the sealed $\mathrm{H}_{2}$ chamber at constant current. The steady-state pressure was recorded, and the gas crossover rate $r_{c o}$ was calculated by Equation 1 as follows:

$r_{c o}\left(\mathrm{~mL} \cdot \min ^{-1}\right)=\frac{i_{c o}}{2 F} \cdot \frac{R T}{P}$

Where $i_{c o}$ is the applied current, $F$ is Faraday's constant, $R$ is the gas constant, $T$ is $293 \mathrm{~K}$, and $P$ is 1.013 bar. The crossover rate can be taken as indicative of both membrane gas crossover and cell sealing, since the method described includes all gas pressure loss sources in the hydrogen chamber.

With gas crossover rate and cell voltage, the combined efficiency at different currents can be estimated by Equation 2 as:

$$
\varepsilon_{\text {comb }}=\varepsilon_{\text {Farad }} \cdot \varepsilon_{\text {therm }}=\left(\frac{i_{\text {cell }}}{i_{\text {cell }}+i_{\text {co }}}\right) \cdot \frac{E_{\text {th }}}{E_{\text {cell }}}
$$


$10^{\mathrm{TH}}$ INTERNATIONAL CONFERENCE ON SUSTAINABLE ENERGY AND ENVIRONMENTAL Protection (June $27^{\mathrm{TH}}-30^{\mathrm{TH}}, 2017$, Bled, Slovenia), ENERGy Storage

A. L. Tomas-Garcia, M. Mirzaeian, G Chisholm \& A. G.Olabi: Design and Testing of a

Single-Cell PEM Electrolyser for Small-Scale Hydrogen Production Under Mild

Conditions

With $i_{c o}$ being the crossover current density, $i_{\text {cell }}$ the applied cell current, $E_{\text {cell }}$ the measured cell voltage, and $E_{t h}$ the thermoneutral voltage for water splitting, $+1.48 \mathrm{~V}$ (HHV) in operating conditions.

\section{$3 \quad$ Results and Discussion}

\subsection{Cell compressibility and bolt torque}

Figure 2 shows the effect of applied torque to the bolts clamping the cell on its ohmic resistance, cell voltage and gas crossover. It can be seen how the applied torque in the bolts during cell assembly has a strong influence in its measured ohmic resistance and gas crossover. This can be attributed to the behaviour of interfacial contact resistance between cell layers, such as current collectors and gas diffusion layers. The results obtained are in good agreement with recent work published by Selamet and Ergoktas on a similar PEM system[6], although in that case different gasket materials were used, and cell performance was measured at room temperature.

It is worth noting that, on the one hand, higher torque (and hence higher clamping pressures) is beneficial for minimizing the cell's internal resistance; on the other hand, as interfacial resistance is overcome, a minimum residual resistance remains, which is closer to the sum of the individual bulk resistances of the cell's components. If higher torques are applied, in addition of no significant improvement in cell resistance and/or sealing, excessive strain on cell materials can produce mechanical failure of softer components like gaskets and membranes. Therefore, in any cell design a compromise might be sought when considering applied clamping pressure, between performance and mechanical integrity. 
$10^{\mathrm{TH}}$ International Conference on Sustainable Energy and Environmental Protection (June $27^{\mathrm{TH}}-30^{\mathrm{TH}}, 2017$, Bled, Slovenia), Hydrogen and Fuel Cells A. L. Tomas-Garcia, M. Mirzaeian, G Chisholm \& A. G.Olabi: Design and Testing of a Single-Cell PEM Electrolyser for Small-Scale Hydrogen Production Under Mild Conditions

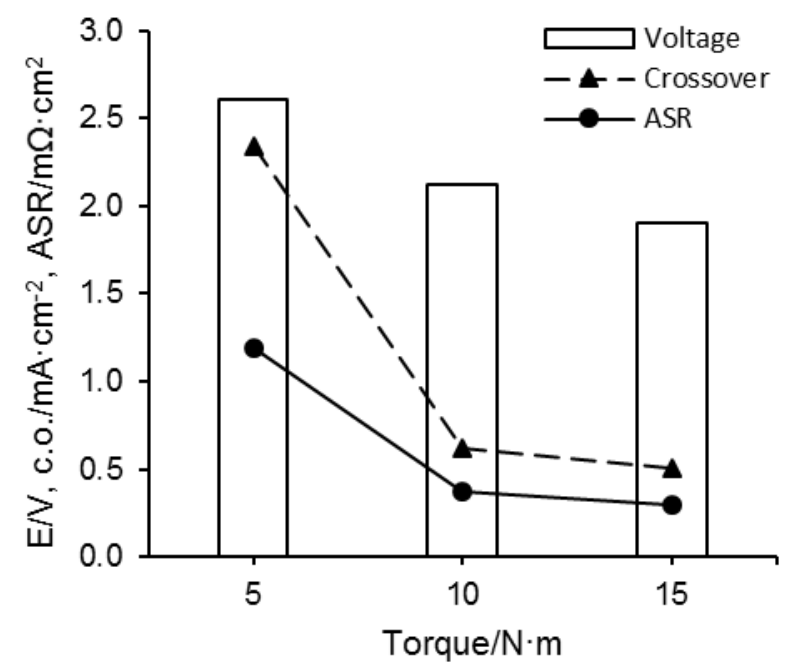

Figure 2. Measured cell voltage, gas crossover (c.o.) rate and ASR for Cell C, at different applied bolt torques.

The compression behaviour of the cell assembly is likely correlated to that of the softness of polymeric components, such as gaskets and membrane, compared to stiffer ones such as endplates and GDL layers.

\subsection{CCM configuration}

Figures 3, 4 and 5 show the performance of cells with different membranes (C, D and E), tested through i-V curves, EIS spectra and gas crossover. The i-V curves show lower voltage for Cells D and E. The EIS spectra (Figure 4) show a single semicircle for the Nafion membrane (Cell C), while a wider shape with probably two different circles was observed for the PFSA membranes (Cells C and D); this is possibly due to different electrode microstructures in each of CCMs. The main difference between membranes seems to be their ohmic resistance; this can in turn be attributed to differences in membrane resistance, with the PFSA membrane being more conducting at $40^{\circ} \mathrm{C}$ than the Nafion membrane. It can also be added that the mechanical reinforcement applied to the PFSA membrane in Cell E did not seem to be detrimental to cell performance, with very similar ohmic resistance and total cell resistance at $100 \mathrm{~mA} \cdot \mathrm{cm}^{-2}$. In Figure 5, the cell combined efficiency $\varepsilon_{\text {comb }}$ at different current densities is shown, calculated from gas crossover and cell voltage (Equation 2). Cell $\mathrm{C}$ had superior efficiency at low current density, due to its lower gas crossover. On the other hand, Cells D and E showed superior efficiency at current densities, reflecting the influence of ohmic resistance on voltage efficiency. 
A. L. Tomas-Garcia, M. Mirzaeian, G Chisholm \& A. G.Olabi: Design and Testing of a Single-Cell PEM Electrolyser for Small-Scale Hydrogen Production Under Mild Conditions

When different catalyst loadings were applied to Nafion membranes, the differences in performance were much smaller (Table 2); e.g. halving Ir loading in Cell B compared to Cell A only increased cell voltage by $8 \mathrm{mV}$ at $100 \mathrm{~mA} \cdot \mathrm{cm}^{-2}$, and halving Pt loading in Cell C compared to Cell A decreased cell voltage by $3 \mathrm{mV}$. Recent work by Grigoriev et al.[7] has shown similar results in the catalyst loading range used here, with minimal performance changes for cathode $\mathrm{Pt}$ loadings between 0.5 and $2 \mathrm{mg} \cdot \mathrm{cm}^{-2}$.

Table 2. IR-compensated cell voltage at $100 \mathrm{~m} \cdot \mathrm{Acm}^{-2}$ for Nafion $115 \mathrm{CCMs}$ with different catalyst loadings.

\begin{tabular}{|l|l|l|l|l|}
\hline Cell ID & $\begin{array}{l}\text { Pt loading/ } \\
\mathrm{mg} \cdot \mathrm{cm}^{-2}\end{array}$ & $\begin{array}{l}\text { Ir loading/ } \\
\mathrm{mg} \cdot \mathrm{cm}^{-2}\end{array}$ & $\begin{array}{l}\mathrm{E}-\mathrm{I} \cdot \mathrm{R} / \\
\mathrm{V}\end{array}$ & $\begin{array}{l}\text { Crossover/ } \\
\mathrm{mL} \cdot \mathrm{min}^{-1}\end{array}$ \\
\hline $\mathrm{A}$ & 1.0 & 2.0 & 1.580 & 0.21 \\
\hline $\mathrm{B}$ & 1.0 & 1.0 & 1.588 & 0.21 \\
\hline $\mathrm{C}$ & 0.5 & 1.0 & 1.577 & 0.20 \\
\hline
\end{tabular}

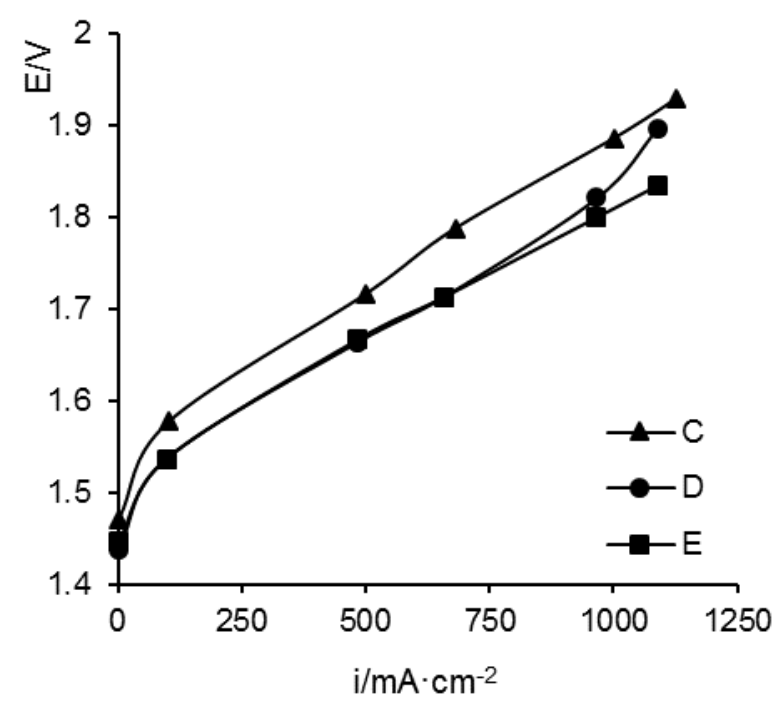

Figure 3: i-V curves for different Cells: $\mathrm{C}(\boldsymbol{\Delta})$ Nafion, $\mathrm{D}(\bullet)$ PFSA, E( $\bullet$ PFSA-R. Obtained at $40{ }^{\circ} \mathrm{C}$ and $\mathrm{P}_{\mathrm{H} 2}=6.9 \mathrm{barg}$. 
148 10 $10^{\mathrm{TH}}$ International Conference on Sustainable Energy and EnVIRONMENTAL Protection (June $27^{\mathrm{TH}}-30^{\mathrm{TH}}, 2017$, Bled, Slovenia), Hydrogen and Fuel Cells

A. L. Tomas-Garcia, M. Mirzaeian, G Chisholm \& A. G.Olabi: Design and Testing of a Single-Cell PEM Electrolyser for Small-Scale Hydrogen Production Under Mild Conditions

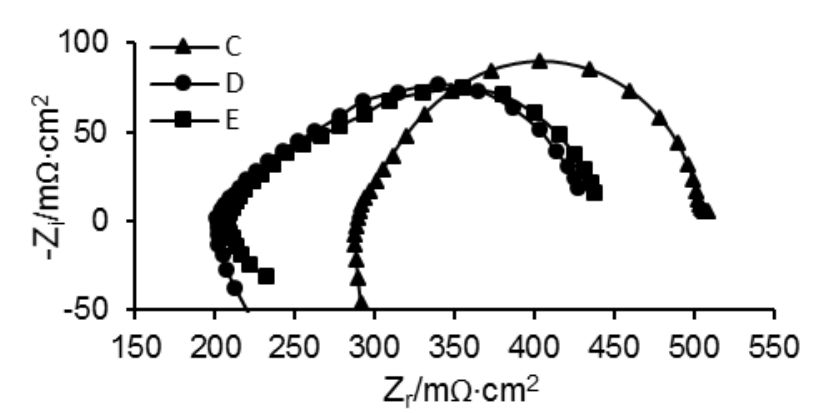

Figure 4. EIS spectra for Cells C, D, E. Obtained at $100 \mathrm{~mA} \cdot \mathrm{cm}^{2}$.

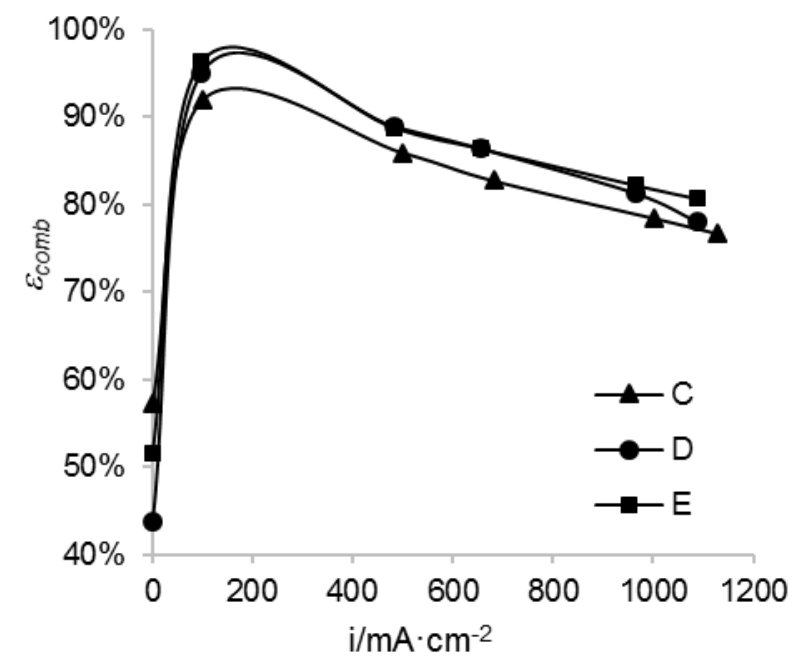

Figure 5. Calculated cell efficiency $\varepsilon_{\text {comb }}$ for Cells C, D, E. Same conditions as Figure 3.

\section{$4 \quad$ Conclusions}

In the relatively mild conditions in which the cell designs were tested, membrane selection and gasket compression were more important for cell performance than catalyst loading, at least within the studied range of loadings. Membrane selection had an important influence in ohmic resistance, with the PFSA CCMs showing lowest resistance. Clamping pressure of the cell, applied through controlled bolt torque, played also an important role in optimizing resistance. In this design, $15 \mathrm{~N} \cdot \mathrm{m}$ torque was found to provide the best ohmic resistance, cell voltage and gas crossover. 
$10^{\mathrm{TH}}$ INTERNATIONAL CONFERENCE ON SUSTAINABLE ENERGY AND ENVIRONMENTAL Protection (June $27^{\mathrm{TH}}-30^{\mathrm{TH}}, 2017$, Bled, SLOVEnia), EnERGy Storage

A. L. Tomas-Garcia, M. Mirzaeian, G Chisholm \& A. G.Olabi: Design and Testing of a Single-Cell PEM Electrolyser for Small-Scale Hydrogen Production Under Mild Conditions

\section{Acknowledgements}

The authors would like to acknowledge the funding support provided by Peak Scientific Instruments Ltd, the University of the West of Scotland (UWS) and the Knowledge Transfer Partnership (KTP) Scheme of Innovate UK.

\section{References}

[1] D. G. Bessarabov, H. Wang, H. Li, and N. Zhao, Eds., PEM electrolysis for hydrogen production: principles and applications. Boca Raton, Florida: CRC Press, 2016.

[2] M. Carmo, D. L. Fritz, J. Mergel, and D. Stolten, "A comprehensive review on PEM water electrolysis,” Int. J. Hydrog. Energy, vol. 38, no. 12, pp. 4901-4934, Apr. 2013.

[3] S. Siracusano, V. Baglio, A. Stassi, L. Merlo, E. Moukheiber, and A. S. Arico', "Performance analysis of short-side-chain Aquivion ${ }^{\circledR}$ perfluorosulfonic acid polymer for proton exchange membrane water electrolysis," J. Membr. Sci., vol. 466, pp. 1-7, Sep. 2014.

[4] D. Rood, The Troubleshooting and Maintenance Guide for Gas Chromatographers. Weinheim, Germany: Wiley-VCH Verlag GmbH \& Co. KGaA, 2007.

[5] M. Schalenbach, T. Hoefner, P. Paciok, M. Carmo, W. Lueke, and D. Stolten, "Gas Permeation through Nafion. Part 1: Measurements," J. Phys. Chem. C, vol. 119, no. 45, pp. 25145-25155, Nov. 2015.

[6] O. F. Selamet and M. S. Ergoktas, "Effects of bolt torque and contact resistance on the performance of the polymer electrolyte membrane electrolyzers," J. Power Sources, vol. 281, pp. 103-113, May 2015.

[7] S. A. Grigoriev and A. A. Kalinnikov, "Mathematical modeling and experimental study of the performance of PEM water electrolysis cell with different loadings of platinum metals in electrocatalytic layers," Int. J. Hydrog. Energy, vol. 42, no. 3, pp. 1590-1597, Jan. 2017. 
$150 \quad 10^{\mathrm{TH}}$ International CONFERENCE ON Sustainable EnERgy and EnVIRONMENTAL Protection (June 27 $7^{\mathrm{TH}}-30^{\mathrm{TH}}, 2017$, Bled, Slovenia), Hydrogen And Fuel Cells 
$10^{\mathrm{TH}}$ InTERnational CONFERENCE ON Sustainable ENERgy AND EnVironmental Protection (June $27^{\mathrm{TH}}-30^{\mathrm{TH}}$, 2017, Bled, Slovenia), Hydrogen ANd Fuel Cells

J. Krope, A.Ghani Olabi, D. Goričanec \& S. Božičnik

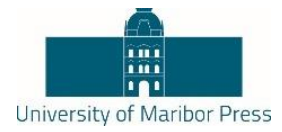

\title{
European-Wide Field Trials for Residential Fuel Cell Micro-CHP
}

\author{
TADEJ AUER \& MiKe SMALL
}

\begin{abstract}
Ene.field and other like PACE project are needed for a large scale Fuel Cell mCHP deployment that enables suppliers to overcome the point of greatest risk in new product commercialisation and a significant cost reduction is required to move the technology to a commercial proposition. Ene.field is the largest European demonstration of $\mathrm{FCmCHP}$ to date, deploying up to 1,000 FCmCHP in 11 key European member states in duration of 5 years.
\end{abstract}

Outputs of the project include LCC\&LCA assessments, market analysis, commercialization strategy, and policy recommendations.

It is shown that Germany is the strongest early market, due to regional funding opportunities, tolerance of higher cost heating systems and a more developed manufacturer base. Increased manufacturing volumes is expected to be the biggest driver of capital cost reductions, which will require a stable policy framework.

About policy readiness, with ene.field, we learned that policy development should closely follow and complement the industry's commitment to FCmCHP cost reduction and performance improvements. Current national administrative barriers are preventing access to existing support schemes and funding, lack of political recognition of FCmCHP benefits.

The Fuel Cells and Hydrogen Joint Undertaking (FCH JU) is committing $€ 26$ million to ene.field under the EU's 7th Framework Programme.

Keywords: • Micro-CHP Fuel Cell residential energy distribution system - product commercialization $\bullet$ manufacturing volumes $\bullet$ policy readiness $\bullet$ standard harmonisation •

CoRrespondence AdDRess: Tadej Auer, M.Sc., director of Development Centre for Hydrogen Technologies, Reteče 4, 4220 Škofja Loka, Slovenia, e-mail: tadej.auer@rcvt.si. Mike Small, COGEN Europe/BDR Thermea Netherlands, e-mail: projects@cogeneurope.eu, Carsten Brorson Prag, Technical University of Denmark, e-mail: cbrpr@dtu.dk. 

$10^{\text {TH }}$ International Conference on Sustainable Energy and Environmental Protection (June $27^{\mathrm{TH}}-30^{\mathrm{TH}}, 2017$, Bled, Slovenia), Hydrogen and Fuel Cells T. Auer \& M. Small: European-Wide Field Trials for Residential Fuel Cell Micro-CHP Introduction

This position paper is a part of Europe's largest demonstration project for fuel-cell-based mCHP (micro combined heat and power) systems, ene.field (European-wide field trials for residential FCmCHP, grant no. 303462). The aim of the project is to demonstrate small stationary fuel cell systems for residential and commercial applications. The project is deploying almost $1000 \mathrm{FCmCHP}$ units in $10 \mathrm{EU}$ member states. This is a step change in the volume of FCmCHP deployment in Europe and an important step to push the technology towards commercialization. The project involves 26 partners. Besides the manufacturers of the FC systems, several research institutes as well as utilities are also involved as partners in the project.

This position paper was written in the framework of the ene.field project. The paper was curated and partly written by the Technical University of Denmark (Carsten Brorson Prag, Jonathan Hallinder and Eva Ravn Nielsen). Input regarding the FC mCHP integration (Chapter 2) is based on was provided by Baxi Innotech, Bosch, Ceramic Fuel Cells, Dantherm Power, Elcore, Riesaer Brennstoffzellen technik, SOLIDpower and Vaillant. Contributions to the discussion of FCmCHPs from a utility perspective (Chapter 3) were made by Dong Energy, Dolomiti Energia, GDF-SUEZ and British Gas.

\section{General Introduction to Smart Grids}

A smart grid is an extension of the current electrical grid, as seen in Europe or North America. The definition of a smart grid is nebulous because a smart grid is more defined by what it seeks to achieve than how it achieves it. A smart grid is an allencompassing coordination of the capabilities and needs of generators, grid operators and end-users. As any grid it seeks to stabilise the delivery of electricity. Additionally, it aims to achieve a higher utilisation of resources compared to traditional grids using advanced technologies. This can be achieved in a number of ways and with a host of tools depending on the situation, the utilities, the grid managers and the consumers. 


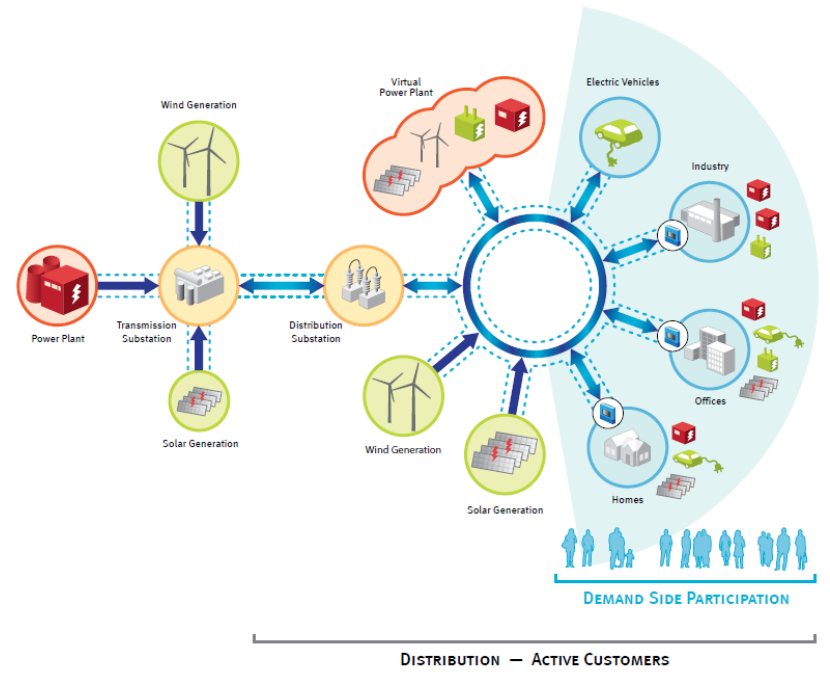

Figure 1. Visual representation of the smart grid. The key concepts are the decentralised generation and the distribution flexibility [4]

With the introduction of smart grids, we see the emergence of a trend towards higher decentralisation of the energy system with the following benefits: A smart grid will aid limiting losses in transmission [1] through a constant analysis of the grid [2]. A smart grid can also aid distributed generation by minimising the distance from generation to consumption thus limiting the need for long range transmission at all.

Smart grids will span over all distribution and generation levels ranging from high to low voltage grid, large to small scale production and remote as well as on-site control of decentralised generation [3] (see Figure 1).

\subsection{Why do we need a smart electricity grid?}

Intermitted sources such as wind power and photovoltaic (PV) generation require that other generation system in the grid can quickly and flexibly react to a change of production. As the intermittent renewable sources are fluctuating, other systems will have to be able to start up, resume production, go idle or shut down in reaction to the intermittent electricity generation. While this is all happening in the traditional grid introduction of new technologies, such as heat pumps, electric vehicles, electrolysers and mCHPs, will require faster and more intricate communication between all the components connected to the grid.

At times of high energy production from renewable resources, excess energy will be stored in order to be used in times of low energy production from renewable resources. Storages can come in several forms such as: Pumped hydro storage (PHS), compressed air energy storage, batteries, flywheels and gas storage (from electrolysis). All of these 
$10^{\mathrm{TH}}$ InTERnAtional CONFERENCE ON Sustainable ENERgy AND ENVIRONMENTAL Protection (June $27^{\mathrm{TH}}-30^{\mathrm{TH}}, 2017$, Bled, Slovenia), Hydrogen and Fuel Cells

T. Auer \& M. Small: European-Wide Field Trials for Residential Fuel Cell Micro-CHP

have different energy recovery times ranging from seconds to tens of minutes. Coordination of storage of energy over such large quantity of units and technologies as well as the coordination of utilisation of aforementioned stored energy will require a smart grid.

One thing is certain: There is no "silver bullet" technology solution to address the decarbonisation of the electricity system while still ensuring grid stability in a cost effective way. The future energy supply will most likely be based on several different technologies with a large variety of power output [5]. These technologies will make up a complex mix in the power grid. The preference for these technologies will of course depend on geographical location. Every technology has requirements and advantages which makes them more or less well suited for a specific region, country or terrain.

Wind and solar power are intermittent and will therefore increase the need for grid balancing energy storages. Fuel cells are also included as they are tightly linked to energy recovery from hydrogen and synthetic fuel storage. While other recovery technologies exist, fuel cells are among the most efficient and have a low carbon impact.

\section{$2.2 \quad$ Fuel-cell-based micro-CHP systems}

Micro-CHP systems are co-generation systems. According to the European definition, a $\mathrm{mCHP}$ system has a maximum electric power output of $50 \mathrm{~kW}$ [6]. The electrical efficiency of a FCmCHP system has been reported as high as 60\% [8], total efficiency up to $90 \%$ [7] and $\mathrm{CO} 2$ emissions as low as $240 \mathrm{~g} / \mathrm{kWh}$ [8]. This is comparable to modern combined cycle power plants [9]. The possibility of a high utilization of the produced heat is a big advantage for FCmCHP technology. Micro-CHP systems can be used in buildings off the grid for primary heat and power generation as well as in buildings connected to the grid allowing for the export of excess produced electricity at a profit. Such distributed electricity generation can, as mentioned, potentially increase the power supply security in a future electricity grid when electricity generation from intermittent renewable energy technologies is lacking due to absence of wind or sun.

A mCHP unit needs to be connected to the gas grid (or a separate gas supply such as bottle gas) to fuel the fuel cell. An electricity grid connection is an additional requirement if export of excess electricity and import electricity when there is a production deficit is desired. Figure 2 shows a sketch of a FCmCHP unit installed in a residential house. 


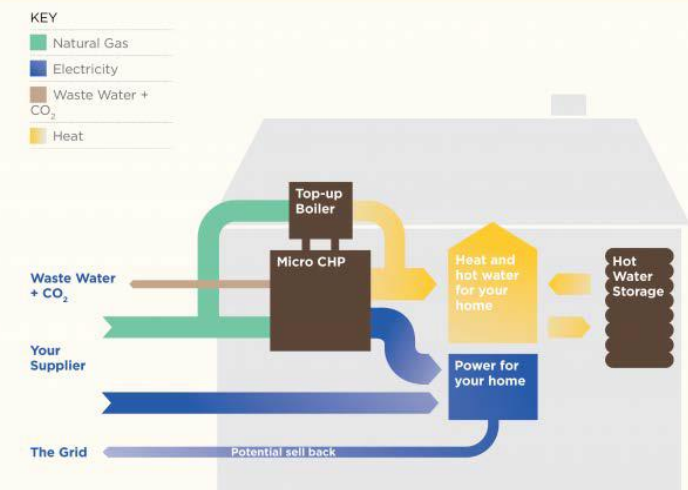

Figure 2. Sketch showing a micro-CHP installed in a residential house [10].

\section{FCMCHP Systems: The Role in a Future Smart Grid}

The capabilities FCmCHPs are well suited to play an important role in the future of an intermittent energy mix. As the power output of the individual system is small, aggregation of systems into virtual power plants is both necessary and possible. This capability exists and has previously been demonstrated. Aggregation can take advantage of the comparatively fast response time of the FC systems. Decentralised generation afforded by mCHPs installed at the point of consumption can limit power transmission losses. Multiple operation modes, are possible and base load operation with the possibility of adjustment based on consumer- and grid needs is suggested.

\subsection{Manufacturers views on the capabilities of FCmCHPs}

The on-site generation from FCmCHPs can contribute to the grid stabilisation at hours of low energy generation from the intermittent sources. Similarly, at times of energy surplus, a FCmCHP can be allowed to go idle. This makes the FCmCHPs compatible with intermittent generation, a desirable trade as balancing the grid in the presence of intermittent generation is expected to be a substantial challenge in years to come.

As the output power of a single FCmCHP system is low, larger clusters, or virtual power plants, are required to make their use practical. Here, combined control or aggregation is used to coordinate the output of a large amount of systems. This requires remote active control of the systems to synchronise the distributed generation of the FCmCHPs. This capability is already proven in manufactured systems.

The aggregator is needed to reach market bid volumes and to pool systems with other generators. Such control could be in the hands of utilities or grid operators and requires operation control of the FCmCHP systems. For running such aggregated virtual power plants, it is necessary that the grid operator knows what the current power output from the FCmCHP units is. It is also necessary that the grid operator has the ability to take 
control of the FCmCHP systems connected to the grid within a pre-established set of conditions.

At operation temperature, FCmCHPs can adjust their power output within seconds to suit the needs of the grid balancing and the household. Start-up from cold to operation temperature may require much longer time. This requirement of a constantly hot cell is not considered a large problem as other factors already created incentives for this. To clarify, these are factors such as ensuring constant performance, grid stabilisation predictability, power export subsidies and household needs. It should be noted that while start/stop cycles may reduce performance, varying the output power does not. This is a great advantage as reducing the output power can in most situations substitute complete shut-down of the FCmCHP system. Currently, electric energy losses from central generation (traditional power plants) to consumption are in the order of 5-8\%. This is mainly due to transmission losses in power lines. With distributed generation, these types of losses can be reduced since electricity is produced at the site of consumption. The fast response time of FCmCHPs together with their aggregation capabilities makes them well suited for smart grid controlled distributed generation.

A FCmCHP can be operated in multiple modes. The most relevant are heat load following, electrical load following, grid following and constant load. As heat load following mode results in suboptimal electricity production and suboptimal economics, it is expected that actual operation will be a combination of electrical load following, grid following and constant load.

One possible way of operation could be the following: By default, the systems are providing base load as long as there is no need for grid balancing. This delivers the best internal rate of return to the home owner. More electricity will be produced if there is power shortage and selling price on the grid (Power Spot Exchange, APX) is high. Less power will be produced if there is more than enough power such as during sunny daytime and windy hours.

\section{Discussion of FCMCHPs From a Utility Perspective}

The technical capabilities for integration of FCmCHPs are present and available. Aggregation of systems into virtual power plants is feasible but relies on competitive economics. This includes investments, running costs and the disadvantage of handling systems with individual owners.

The operation of FCmCHP systems relies on system up-time, response time, consumer needs and grid needs. Ideal operation would be an electrical load-following mode directed by a tailored profile for the individual household with the additional option of automatic adjustment to the internal and external needs. For the utility company to service the individual system owner, control of electrical and thermal power is a necessity. 
$10^{\mathrm{TH}}$ INTERNATIONAL CONFERENCE ON SUSTAINABLE ENERGY AND ENVIRONMENTAL Protection (June $27^{\mathrm{TH}}-30^{\mathrm{TH}}, 2017$, Bled, SLOVEnia), EnERGy Storage

Economic subsidies are at the moment necessary. In countries with feed-in tariffs, these are the driving factor. Non-economic barriers and hidden costs play a large role in some markets, while standardisation and clarity would greatly help market development.

\subsection{Aggregation}

Some major assumptions for small scale FCs to reach remarkable future shares of the coming balancing market for power are:

- That aggregation is possible for many small units through a common system that can control many small units and balance outputs.

- Fast response times for each single unit, which mostly will mean that systems have to be at operation temperature.

- Economic competitive solutions.

Aggregated FCmCHP VPPs will only be of interest for utilities if the system is economic competitive with conventional methods for balancing of power networks. "Economic competitive" covers both investment and running cost for the system as well as all the costs connected to the bureaucracy introduced by the handling of systems with many thousand owners.

\subsection{Operation}

The use of FCmCHP units in a smart grid context, introduces into the operational management a certain number of issues never approached in a normal household.

The need of an aggregation of systems implemented through a full remote control managed by an external operator instead of the single owner of the single system definitely requires the possibility of a real-time exchange of information relevant to the operation condition of the units. All this must be combined with knowledge of the technical characteristics of the unit itself.

When considering the response times of a FC unit to a load variation request, there are two general scenarios to consider:

1) If the response times are in the range of seconds or milliseconds, system operators will function as distributors in terms of the provision of grid services such as regulation of the reactive power, local adjustment of voltage and the reduction of grid congestion.

2) If, on the other hand, the reaction times are measured in minutes, or more, the only kind of operator who could be interested is a "commercial" operator (seller), who may obviate the need for displacement for production programs or for market needs. That is, an operator who only regulates power output based on commercial needs and not on grid technical needs.

An ideal solution for the utility companies would be electrical load following mode, such as the one proposed by the manufacturers in the previous chapter, optimized by a well- 
$10^{\text {TH }}$ InTERnational CONFERENCE ON Sustainable ENERgy AND ENVIRONMENTAL Protection (June $27^{\mathrm{TH}}-30^{\mathrm{TH}}, 2017$, Bled, Slovenia), Hydrogen and Fuel Cells

T. Auer \& M. Small: European-Wide Field Trials for Residential Fuel Cell Micro-CHP

designed heat storage capacity (based on the total day heat demand with no waste energy), and a daily stepped pre-set load profile based on a "typical" energy need profile of the end user. This profile should then automatically be adjusted according to the demand over time or manually by the "network operator" via remote control for grid balancing needs.

\subsection{Data, metering and control}

The currently available systems for metering, data collection and system control are in themselves sufficiently advanced to fill their required roll in a future integration of FCmCHPs in a smart grid. The response time of the FCmCHPs may however pose a limitation to the practical use of these metering and control systems.

If a utility company is to serve the individual customer via incorporation of FCmCHPs, they must be able to control the output of the installed unit. The utility company must be able to control either the electrical or the thermal power output of the units as a minimum. If the mCHPs are to be used in a smart grid context, it must be possible to control the electrical power output specifically.

\subsection{Economics}

The deployment and economics of FCmCHPs are still very much subsidy driven. The most commonly seen subsidy mechanism, or incentive, is the feed-in tariff (FiT) regime.

In countries where no FiTs are available, it is possible that the cost of purchase and installation of the mCHP unit becomes insurmountable for the consumer. Whichever benefits there may be in installing a FCmCHP are overshadowed by the initial expenditure. In these countries without FiTs some expenses may not be apparent from the onset as paperwork and bureaucratic processes may also result in obfuscated costs. This alienates the consumer, not only to the system but to the product as well.

\subsection{Distributed generation}

As mentioned in the previous chapter, a reduction of transmission losses will be afforded by the in-house generation promised by technologies such as FCmCHPs. To make a difference in practice mCHP installation volumes must be in the order of several thousands. The grid capacity will in practice be increased as grid electricity demand will be reduced by the distributed generation. That is to say, the existing power loss of 5-7\% from power station to consumer will be minimised through the local mCHP power production.

\subsection{Limiting factors and challenges}

The greatest limiting factor, as seen from a utility perspective, to the introduction of FCmCHPs to the market in a broad sense, is the cost of the units. The reliance on subsidies is pervasive and will continue until large enough manufacturing numbers are met. 
$10^{\mathrm{TH}}$ INTERNATIONAL CONFERENCE ON SUSTAINABLE ENERGY AND ENVIRONMENTAL Protection (June $27^{\mathrm{TH}}-30^{\mathrm{TH}}, 2017$, Bled, SLOVEnia), EnERGy Storage

T. Auer \& M. Small: European-Wide Field Trials for Residential Fuel Cell Micro-CHP

FCmCHPs are an interesting option for balancing and aligning the grid for renewable energy sources. The technology promises assistance in the compensation of the fluctuations caused by intermittent energy sources and has the potential of being an attractive technology with low environmental impact. The capacity to function in aggregates where each FCmCHP unit is controlled individually and remotely has already been demonstrated in commercial systems. An additional advantage is that a FCmCHP at operation temperature can adjust its power output within seconds to quickly fit either grid balancing needs or the needs of the household where it is installed.

The promise of grid stabilisation through aggregation of fuel cell mCHPs is enticing. To realise the potential, this technology depends both on bringing the unit costs down as well as on putting in place a framework that creates a market for balancing and other ancillary services. Such a framework should attract new players and new business models that can help to facilitate the process. Aggregators are expected to step in, once the market offers greater rewards for flexible generation and appropriate contractual arrangements can be made to ensure that both the unit owners and aggregators draw benefits from such an arrangement.

It is recommended that the FCmCHPs are in general operated in an electrical load following mode with a well-designed heat storage capacity. A load profile based on a typical energy need should be applied and adjusted automatically according to demand or grid balancing need. The resources for such operation are available and are in themselves not a limiting factor.

\section{References}

[1] A. Devidas and M. Ramesh, ""Wireless Smart Grid Design for Monitoring and Optimizing Electric Transmission in India,"," in Sensor Technologies and Applications (SENSORCOMM), 2010 Fourth International Conference on , 18-25 July 2010.

[2] F. Li, W. Qiao, H. Sun, H. Wan, J. Wang, Y. Xia, Z. Xu and Pei Zhang, " "Smart Transmission Grid: Vision and Framework"," IEEE Transactions on Smart Grid, vol. vol.1, no. no.2, pp. pp. $168,177,2010$.

[3] OECD and IEA, "Technology Roadmap: Smart Grids," 04 2011. [Online]. Available: https://www.iea.org/publications/freepublications/publication/smartgrids_roadmap.pdf. [Accessed 8 July 2015].

[4] Eurelectric, 1504 2011. http://www.eurelectric.org/media/26140/broch.10steps_lr-2011030-0304-01-e.pdf. [Accessed 8 July 2015]

[5] OECD/IEA, “Energy Technology Perspectives 2014,” OECD/IEA, 2014.

[6] "Directive 2004/8/EC by the European parliament, The promotion of cogeneration based on a useful heat demand in the internal energy market and amending Directive 92/42/EEC," European parliament, 2004.

[7] COGEN Europe, "The benefits of micro-CHP," 19 May 2015. [Online]. Available: http://www.cogeneurope.eu/medialibrary/2015/05/19/d6648069/miro-

CHP\%20study_merged.pdf. [Accessed 12 October 2015].

[8] Solid Power, "BlueGen haeufige fragen faq," [Online]. Available: http://www.ceramicfuelcells.de/de/produkte/bluegen/haeufige-fragen-faq/. [Accessed 9 October 2015]. 
$160 \quad 10^{\mathrm{TH}}$ InTERnational CONFERENCE ON Sustainable EnERgy and EnVIRONMENTAL Protection (June $27^{\mathrm{TH}}-30^{\mathrm{TH}}, 2017$, BLed, Slovenia), Hydrogen AND Fuel Cells

T. Auer \& M. Small: European-Wide Field Trials for Residential Fuel Cell Micro-CHP

[9] Siemens , "Combined Cycle Power Plants," Siemens, , [Online]. Available: http://www.siemens.com/about/sustainability/en/environmental-portfolio/productssolutions/fossil-power-generation/combined-cycle-power-plants.htm. [Accessed 9 July 2015].

[10] “ene.field project,” 1311 2014. http://enefield.eu/. [Accessed 8 July 2015]. 
$10^{\mathrm{TH}}$ INTERNATIONAL CONFERENCE ON Sustainable ENERgy AND ENVIRONMENTAL Protection (June $27^{\mathrm{TH}}-30^{\mathrm{TH}}$, 2017, Bled, Slovenia), Hydrogen ANd Fuel Cells

J. Krope, A.Ghani Olabi, D. Goričanec \& S. Božičnik

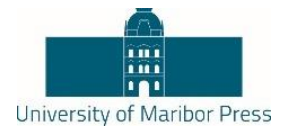

\title{
Exploring the Profit Potential of Energy Storage in a Car Park Using Electrolysis, Hydrogen Storage and Fuel Cell Electric Vehicles
}

\author{
REINIER VAN DER VEEN, REMCO VERZIJLBERGH, ZOFIA LUKSZO \& AD VAN WIJK
}

\begin{abstract}
The Car Park as Power Plant (CPPP) is a main business concept related to a future integrated sustainable mobility and energy system in which hydrogen is a key energy carrier. In order to investigate the uncertain profitability of the CPPP concept, an optimisation model has been developed of a CPPP system that includes an electrolyser, a hydrogen storage tank, and fuel cell electric vehicles, which can produce electricity from hydrogen. The potential profits that can be obtained with electricity price arbitrage through energy storage are explored by means of various energy market scenarios. It is concluded that the CPPP electricity arbitrage business model can be profitable for a future system with a high share of wind and solar power, but that profit levels are highly dependent on electricity prices in hours with low wind and solar power generation.
\end{abstract}

Keywords: • car park $\bullet$ fuel cell electric vehicle $\bullet$ electrolysis $\bullet$ hydrogen storage $\bullet$ vehicle-to-grid $\bullet$

CoRRESPONDENCE AdDRESS: Reinier van der Veen, Ph.D., Post-doc, Delft University of Technology, Faculty of Technology, Policy and Management, Jaffalaan 5, 2628 BX Delft, the Netherlands, e-mail: r.a.c.vanderveen@tudelft.nl. Remco Verzijlbergh, Ph.D., Assistant Professor, Delft University of Technology, Faculty of Technology, Policy and Management, Jaffalaan 5, 2628 BX Delft, the Netherlands, e-mail: r.a.verzijlbergh@tudelft.nl. Zofia Lukszo, Ph.D., Associate Professor, Delft University of Technology, Faculty of Technology, Policy and Management, Jaffalaan 5, 2628 BX Delft, the Netherlands, e-mail: z.lukszo@tudelft.nl. Ad van Wijk, Prof., Professor, Delft University of Technology, Faculty of Mechanical, Maritime and Materials Engineering, Mekelweg 2, 2628 CD Delft, the Netherlands, e-mail: a.j.m.vanwijk@tudelft.nl.

https://doi.org/10.18690/978-961-286-054-7.15

ISBN 978-961-286-054-7

(C) 2017 University of Maribor Press

Available at: http://press.um.si. 
$16210^{\mathrm{TH}}$ InTERnational CONFERENCE ON Sustainable ENERGy AND ENVIRONMENTAL Protection (June $27^{\mathrm{TH}}-30^{\mathrm{TH}}, 2017$, Bled, Slovenia), Hydrogen and Fuel Cells R. van der Veen, R. Verzijlbergh, Z. Lukszo \& A. van Wijk: Exploring the Profit Potential of Energy Storage in a Car Park Using Electrolysis, Hydrogen Storage and Fuel Cell Electric Vehicles

\section{$1 \quad$ Introduction}

\subsection{Hydrogen as a Main Energy Carrier}

To reach the high greenhouse gas emission reductions required to mitigate climate change, our fossil-based economy must transform into a low-carbon economy that makes use of renewable energy sources. For the power sector, this means a system based on variable renewable energy (VRE), notably wind and solar power, while in the mobility sector the main technology option is considered to be the electric vehicle, including battery vehicles, and fuel cell electric vehicles (FCEVs), which convert hydrogen $\left(\mathrm{H}_{2}\right)$ into electricity for propulsion [1]. The Car as Power Plant concept entails a vision of an integrated sustainable energy and mobility system, based on VRE, hydrogen production and storage, and FCEVs [2]. It offers an energy transition pathway that brings along various technical and economic synergies. Electricity can be converted to hydrogen using electrolysers when VRE generation exceeds demand, hydrogen can be stored on a large scale for periods up to months, and FCEVs can generate power when wind and solar power output are insufficient [3], [4], [5]. In a future power system based on intermittent wind and solar power, the tasks of real-time energy balancing and overall load levelling will become much more substantial. The need for back-up power generation capacity will become particularly pressing in case of multi-day periods without wind or sun. The use of FCEVs for power production results in a more efficient use of passenger cars, which are standing still more than $95 \%$ of the time, and reduces the need to invest in little-used back-up power plants [2].

\subsection{The Car Park as Power Plant}

A main business concept related to the Car as Power Plant concept is that of the car park as power plant (CPPP), which consists of the aggregation of FCEVs parked in a car park into a 'virtual power plant' to produce electricity and feed it into the power grid. In contrast to battery vehicles, the availability of FCEVs for driving and power provision is not constrained by VRE output and power line capacities, as they are powered by hydrogen. Advantages of aggregating FCEVs within the boundaries of a car park are that the required vehicle-to-grid (V2G) infrastructure and other system components can be integrated within the car park building, and that possible compensation for drivers can be factored into the parking fee.

The CPPP business concept encompasses many business model options, involving different business developers (e.g., car park operator, energy company, mobility service provider), products and services (e.g., parking, power system services, heat), and related system designs (e.g., V2G infrastructure only, inclusion of hydrogen storage tank, inclusion of electrolyser). In this work, we focus on the business model of electricity price arbitrage, where electricity is converted to hydrogen when prices are low and hydrogen is converted back to electricity when prices are high, incorporating hydrogen production and storage within the car park. This particular model was chosen because it 
$10^{\mathrm{TH}}$ INTERNATIONAL CONFERENCE ON SUSTAINABLE ENERGY AND ENVIRONMENTAL Protection (June $27^{\mathrm{TH}}-30^{\mathrm{TH}}, 2017$, Bled, Slovenia), ENERGy Storage

R. van der Veen, R. Verzijlbergh, Z. Lukszo \& A. van Wijk: Exploring the Profit Potential of Energy Storage in a Car Park Using Electrolysis, Hydrogen Storage and Fuel

Cell Electric Vehicles

represents an elementary CPPP business model design that could play a central part in load levelling in future renewable power systems.

The profitability of the electricity price arbitrage business model (and the CPPP business concept in general) is highly uncertain: It depends on future system costs and electricity market prices. Our research objective is to explore the dependency of profitability of this business model on various energy market conditions. To this end, we perform an optimisation model analysis, in which potential annual profits are explored for different annual power generation, load and price patterns.

\section{Model Description}

We have developed an optimisation model of the car park as power plant applying the electricity price arbitrage business model, 'CPPP model' in short. It has been built in MATLAB, and makes use of the linear programming solver 'linprog'. Below, we describe the model details.

\subsection{Conceptual Design}

The conceptual design of the CPPP model primarily concerns the system design, i.e., the system components that the business developer invests in. These consist of an electrolyser, a hydrogen storage tank, a hydrogen compression system, a hydrogen dispenser (to refuel the FCEVs), V2G dischargers, a rainwater collection system (to obtain water needed for electrolysis), and a reverse osmosis (RO) system (to purify the rainwater). The electrolyser, compression system and dischargers are indispensable components for electricity price arbitrage using FCEVs. The hydrogen storage tank increases the arbitrage potential. The dispenser is used to refill the FCEV tanks. The rainwater collection and RO system enable the production of pure, demineralised water.

The modelled system environment is formed by a specific distribution grid or microgrid, which consists of residential and service sector consumption, wind and solar power capacity, and a merit order list of back-up power capacity.

\subsection{Model assumptions}

The following system-level assumptions apply to the CPPP model:

- The total load of a specific number of households is modelled, along with an equivalent size of service sector load.

- The balance between power production and consumption is not maintained.

- All hydrogen used for $\mathrm{V} 2 \mathrm{G}$ is produced within the CPPP system $\left(\mathrm{H}_{2}\right.$ balance).

- The CPPP operator makes use of one electricity market only (for both buying and selling). 
$10^{\mathrm{TH}}$ InTERnAtional Conference on Sustainable EnERgy AND ENVIRONMENTAL Protection (June $27^{\mathrm{TH}}-30^{\mathrm{TH}}, 2017$, Bled, Slovenia), Hydrogen and Fuel Cells R. van der Veen, R. Verzijlbergh, Z. Lukszo \& A. van Wijk: Exploring the Profit Potential of Energy Storage in a Car Park Using Electrolysis, Hydrogen Storage and Fuel Cell Electric Vehicles

- The CPPP operator has perfect foresight of electricity prices and VRE surpluses and shortages in future hours.

- The operation of the CPPP system does not influence the electricity price.

- The CPPP system components other than the electrolyser and the 'FCEV plant' are not subject to energy losses.

- The electrolyser and the FCEV plant can ramp to full capacity instantaneously.

- A single dispenser is used.

- A certain minimum number of cars is available for power production at all hours.

- Fuel cells do not degrade faster due to V2G operation.

- The energy storage service (electricity price arbitrage) is the only service considered. Therefore, parking costs and benefits are not taken into account, the FCEVs are owned by the individual drivers, and on-board tanks are refuelled to original levels.

- No benefits or costs are associated with the oxygen (by-product of electrolysis), and heat and water (by-products of V2G operation).

One of the most important assumptions concerns the hour-to-hour electricity price, which is determined as follows. First of all, the residual load (MWh) is calculated as the electricity demand minus the PV and wind power generation, for each hour in the modelled year. Negative residual load values are transposed into positive VRE surplus values, and positive residual load values into positive VRE shortage values. Secondly, a back-up power generation bid ladder is constructed. The bid ladder is assumed to be linear. Third, the electricity price for hours with a VRE shortage is set at the back-up bid ladder price that corresponds to the back-up capacity volume equal to the VRE shortage. The electricity price for VRE surplus hours is set at a fixed VRE surplus price.

\subsection{Optimisation problem}

The goal of the CPPP operator is to maximise gross profit by optimising the control of the electrolyser and the FCEV plant throughout an entire year, with an hourly time resolution. The corresponding objective function is

$\min _{P_{e l k^{*}, P_{F C E V k}} *} \sum_{\mathrm{k}=1}^{\mathrm{N}_{k}} p_{e k} \cdot E_{e l k}-p_{e k} \cdot E_{F C E V k}$

, where $p_{e k}$ is the electricity price at hour $k(€ / \mathrm{MWh}), E_{\text {elk }}$ is the energy input of the electrolyser at hour $k(\mathrm{MWh}), E_{F C E V k}$ is the energy output of the FCEV plant at hour $k$ $(\mathrm{MWh})$, and $N_{k}$ is the last hour of the period over which the profit is maximised. $P_{\text {elk }} *$ and $P_{F C E V k}{ }^{*}$ are the electrolyser capacity at hour $k(\mathrm{MW})$ and the FCEV plant capacity at hour $k$ (MW), resp.; these are the control variables. The gross profit maximisation is subject to the equality constraint 
R. van der Veen, R. Verzijlbergh, Z. Lukszo \& A. van Wijk: Exploring the Profit Potential of Energy Storage in a Car Park Using Electrolysis, Hydrogen Storage and Fuel

$E_{H k+1}=E_{H k}+\eta_{e l} \cdot P_{e l k} \cdot \Delta t-\frac{1}{\eta_{F C E V}} \cdot P_{F C E V k} \cdot \Delta t$

,where $E_{H k+1}$ is the hydrogen stored at hour ${ }_{k+1}(\mathrm{MWh}), \eta_{e l}$ is the efficiency of the electrolyser, $P_{e l k}$ is the power input of the electrolyser at hour $k(\mathrm{MW}), \eta_{F C E V}$ is the efficiency of the FCEV plant, $P_{F C E V k}$ is the power output of the FCEV plant at hour $k$ (MW), and $\Delta t$ is the time interval (hours). In addition, the following inequality constraints apply:

$$
\begin{aligned}
& 0 \leq P_{e l k} \leq P_{e l_{\text {max }, k}} \\
& 0 \leq P_{F C E V_{k}} \leq P_{F C E V_{\text {max }, k}} \\
& 0 \leq E_{H k} \leq E_{H_{\text {max }, k}}
\end{aligned}
$$

Here, $P_{e l \max , k}$ is the maximum power input of the electrolyser (MW; this is the minimum of the rated electrolyser capacity and the VRE surplus in MW at hour $k$ ), and $P_{F C E V \text { max }, k}$ is the maximum power output of the FCEV plant (MW; this is the minimum of the rated FCEV plant capacity and the VRE shortage in MW at hour $k$ ).

\subsection{Model inputs}

The following main input data are fed into the CPPP model:

- The number of households. For the analysis this was set at 2,000.

- An electricity demand profile, for all hours in a year. The reference profile is based on residential and service consumption data from the Netherlands in 2014, as developed and used in [6].

- Photovoltaic (PV) and wind power generation profiles in MWh, for all hours in a year. Data from the Netherlands from the years 2013, 2014 and 2015 have been used, obtained from [7].

- Installed PV and wind power capacity values in MW.

- A back-up power bid ladder ( $€ / M W h)$, based on 2014 data from the Dutch balancing energy market. The size of the bid ladder is assumed to be $3 \mathrm{MW}$, which is large enough to cover the peak demand of $2.86 \mathrm{MW}$. The minimum and maximum prices on the bid ladder are based on the average Dutch balancing energy market prices at minimum and maximum activated volumes, which are 52.6 and $235.5 € / \mathrm{MWh}$, respectively [8].

- The VRE surplus price $(€ / M W h)$, i.e., the electricity price for hours with a VRE surplus. This is set at $10 € / \mathrm{MWh}$. 
$166 \quad 10^{\mathrm{TH}}$ InTERnAtional CONFERENCE ON Sustainable ENERGy AND ENVIRONMENTAL Protection (June $27^{\mathrm{TH}}-30^{\mathrm{TH}}, 2017$, Bled, Slovenia), Hydrogen and Fuel Cells R. van der Veen, R. Verzijlbergh, Z. Lukszo \& A. van Wijk: Exploring the Profit Potential of Energy Storage in a Car Park Using Electrolysis, Hydrogen Storage and Fuel Cell Electric Vehicles

- Capital cost (in euro per unit of capacity) and O\&M cost (in euro per year, expressed as a percentage of total capital cost) for each of the system components. The used values are projections for 2050, described by [4]. These include capital cost values of $250 € / \mathrm{kW}$ for the electrolyser, $575 € / \mathrm{kg}$ of hydrogen for the storage tank, $4,200 € / \mathrm{kg} / \mathrm{h}$ for the compression system, 72,890 euro per dispenser, and 3,200 euro per 4-point discharger.

- The weighted average cost of capital (WACC). This was set at $3 \%$.

- Energy efficiencies of the electrolyser and the FCEVs, and the lifetime of the system components, based on projections for 2050 [4]. The electrolyser efficiency is set at $82 \%$, and the FCEV efficiency at $61 \%$, following [4].

- The electrolyser capacity (MW) and the hydrogen storage capacity (MWh). The values of these are calibrated and fixed for the main analysis (see section 3).

- The power output of a single FCEV. This is assumed to be $10 \mathrm{~kW}$.

- The number of fuel cell cars that is assumed to be available for power production at all times. This is set at 100 .

\subsection{Model outputs}

The direct results of the model optimisation consist of the hour-to-hour power input values of the electrolyser (MW), the power output values of the FCEV plant (MW), the stored energy values (MWh), and the gross profit $(€)$.

The main result of interest is the net profit, which shows if the investment in the CPPP system is earned back. It is calculated by

$$
N P=\sum_{k=1}^{N_{k}}\left(E_{F C E V k} \cdot p_{e k}-E_{e l k} \cdot p_{e k}\right)-\sum_{i=1}^{N_{i}} T C_{i}
$$

, where $N P$ is the total net profit ( $€ /$ year), $E_{F C E V}$ is the energy output of the FCEV plant at hour $k(\mathrm{MWh}), E_{e l k}$ is the energy input of the electrolyser at hour $k(\mathrm{MWh})$, and $T C_{i}$ is the total cost of individual system component $i$ ( $€ /$ year). The total cost of a component is equal to the sum of the annual capital cost and O\&M cost of that component, with annual capital cost being dependent on the economic lifetime of the component and the WACC. The corresponding equations are identical to those used and presented in [4].

The return on investment (\%) is the gross profit as a share of the total system costs.

Two other important economic performance indicators of the CPPP model are the systemlevelised cost of electricity produced by the CPPP and the system-levelised cost of hydrogen produced by the CPPP. These are calculated by: 
$S L C o E=\frac{\sum_{k=1}^{N_{k}}\left(E_{e l k} \cdot p_{e k}\right)+\sum_{i=1}^{N_{i}} T C_{i}}{\sum_{k=1}^{N_{k}} E_{F C E V k}}$

$S L C o H=\frac{\sum_{k=1}^{N_{k}}\left(E_{e l_{k}} \cdot p_{e k}\right)+\sum_{j=1}^{N_{j}} T C_{j}}{\sum_{k=1}^{N_{k}} E_{e l k} \cdot \frac{\eta_{e l}}{e_{H}}}$

, where SLCoE and SLCoH are the system-levelised cost of electricity ( $€ / \mathrm{MWh})$ and hydrogen $(€ / \mathrm{kg})$, resp., $T C_{j}$ is the total cost of the components $j$ needed for hydrogen production and storage $(€ /$ year $)$, and $e_{H}$ is the specific energy of hydrogen $(\mathrm{MWh} / \mathrm{kg})$.

\section{$3 \quad$ Analysis Results}

\subsection{Calibration of system dimensions}

Given that the modelled power market spans 2,000 households and the capacity of the FCEV plant is $1 \mathrm{MW}$, the capacity of the electrolyser and the hydrogen storage tanks have a certain optimal value. When varying the dimensions of both system components, we find that they should be large enough to utilise the potential for arbitrage with the FCEV plant, but that the profitability of the CPPP business model drops when marginal investment cost surpass marginal revenues. For the reference scenario (4 MW PV, 4 MW wind, 2014 load and generation data), the found optima are an electrolyser capacity of $0.6 \mathrm{MW}$ and a storage capacity of $32 \mathrm{MWh}$. See Figure 1. 
168 10 $10^{\mathrm{TH}}$ InTERnational CONFERENCE ON Sustainable EnERgy and ENVIRONMENTAL Protection (June $27^{\mathrm{TH}}-30^{\mathrm{TH}}, 2017$, Bled, Slovenia), Hydrogen and Fuel Cells R. van der Veen, R. Verzijlbergh, Z. Lukszo \& A. van Wijk: Exploring the Profit Potential of Energy Storage in a Car Park Using Electrolysis, Hydrogen Storage and Fuel Cell Electric Vehicles

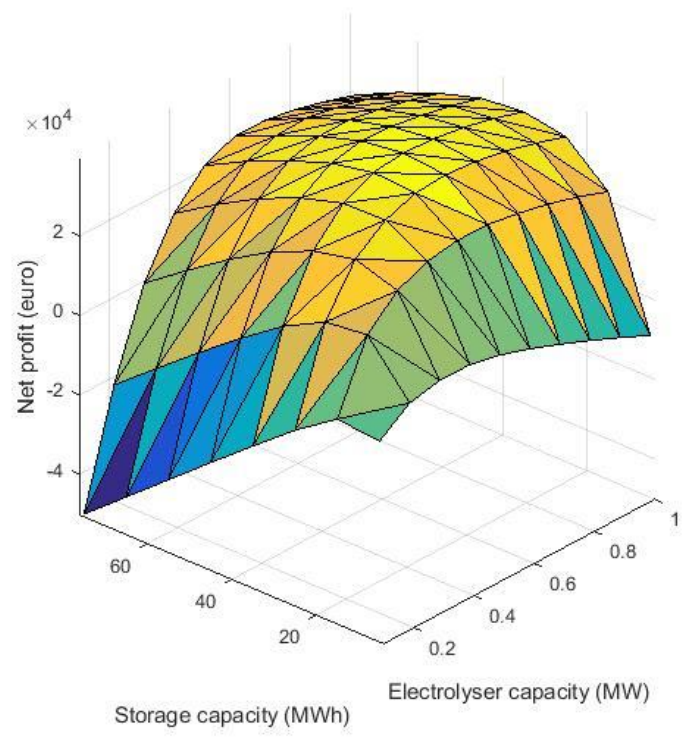

Figure 1. Impact of CPPP system dimensions on profitability for reference scenario

Here, the load factor of the electrolyser is $43 \%$, showing that it can pay off to invest in capacity that enables the sale of more energy in high-price hours.

When performing the same calibration for a scenario with high power production potential (enabled by the load and VRE generation profiles), we found that an electrolyser capacity of $0.9 \mathrm{MW}$ could increase profits by $60 \%$ in this scenario. However, in a scenario with minimum power production potential, no profit could be made. To limit the number of optimisation scenarios, we assume an electrolyser capacity of $0.6 \mathrm{MW}$ and a storage capacity of $32 \mathrm{MWh}$, which produces a net profit in the reference scenario that is close to the average of all scenarios in the main analysis.

\subsection{Sensitivity to market conditions}

We have run the optimisation for 972 scenarios in which six inputs were varied:

- installed PV capacity (3 MW, 4 MW, $5 \mathrm{MW})$

- installed wind power capacity (3 MW, $4 \mathrm{MW}, 5 \mathrm{MW}$ )

- PV generation profile $(2013,2014,2015)$

- wind power generation profile $(2013,2014,2015)$

- load profile (residential, mixed minus $10 \%$, mixed, mixed plus $10 \%$ ) 
$10^{\mathrm{TH}}$ INTERNATIONAL CONFERENCE ON SUSTAINABLE ENERGY AND ENVIRONMENTAL Protection (June $27^{\mathrm{TH}}-30^{\mathrm{TH}}, 2017$, Bled, Slovenia), ENERGy Storage

R. van der Veen, R. Verzijlbergh, Z. Lukszo \& A. van Wijk: Exploring the Profit Potential of Energy Storage in a Car Park Using Electrolysis, Hydrogen Storage and Fuel

Cell Electric Vehicles

- back-up power bid ladder (reference minus $25 € / \mathrm{MWh}$, reference, reference plus $25 € / \mathrm{MWh})^{1}$

All input value combinations have been included in the analysis. This has led to the overall results presented in Table 1 . We find that in $81 \%$ of the scenarios a positive profit develop. The distribution of the net profit values resembles a normal distribution, but with smaller tails. The average gross profit is high, which is necessary to obtain a positive business case: The break-even value lies in the range $80-100 € / \mathrm{MWh}^{2}$. The systemlevelised cost of hydrogen is in the range of the DOE 2020 target value for electrolysis [9]. Profit levels are proportional to the total electricity produced by the FCEV plant, as well as to the back-up bid ladder prices on which the electricity prices are based, which indeed follows from Equation (6). The total electricity produced increases along with the total VRE shortage over the year, until the first becomes larger than ca. 2,000 MWh, in which case the reducing number of VRE surplus hours and the corresponding opportunities for low-cost electrolysis affect the arbitrage potential. The average total electricity produced is $45 \%$ of the average total VRE shortage, which indicates that shortterm energy storage has the potential to supply about half of the residual load.

Table 1. Main Results Of Optimisation Over All Scenarios

\begin{tabular}{|l|l|l|}
\hline Output parameter & Mean & $\begin{array}{l}\text { Standard } \\
\text { deviation }\end{array}$ \\
\hline Net profit $(€ /$ year) & 22,843 & 24,102 \\
\hline Gross profit (€/MWh) & 104.7 & 22.8 \\
\hline Return on investment (\%) & 14.4 & 24.7 \\
\hline Total system cost (M€) cost of & 1.68 & 0 \\
\hline $\begin{array}{l}\text { System-levelised cost of } \\
\text { electricity (€/kWh) }\end{array}$ & 2.0 & 0.0067 \\
\hline $\begin{array}{l}\text { System-levelised } \\
\text { hydrogen }(€ / \mathrm{kg})\end{array}$ & 0.14 \\
\hline Total electricity demand (MWh) & 14,210 & 1,005 \\
\hline VRE surplus hours (\%) & 67.4 & 8.4 \\
\hline Total VRE shortage (MWh) & 2,185 & 664 \\
\hline $\begin{array}{l}\text { Total electricity produced by } \\
\text { FCEV plant (MWh) }\end{array}$ & 982 & 85.0 \\
\hline Load factor of electrolyser (\%) & 37.4 & 3.2 \\
\hline Load factor of FCEV plant $(\%)$ & 11.2 & 0.97 \\
\hline
\end{tabular}

Grouping the results by input value generates a series of box plots (Figure 2). How much PV capacity is installed does not have a significant impact on the net profit, but higher wind capacity values lead to lower net profit values, due to lower total VRE shortage values (power production potential). This indicates that PV production peaks do not match well with the load peaks. Wind generation patterns are much more irregular than PV patterns, which is reflected by the differences between (profile data from) different 
$170 \quad 10^{\mathrm{TH}}$ International Conference On Sustainable EnERgy and Environmental Protection (June $27^{\mathrm{TH}}-30^{\mathrm{TH}}, 2017$, Bled, Slovenia), Hydrogen and Fuel Cells R. van der Veen, R. Verzijlbergh, Z. Lukszo \& A. van Wijk: Exploring the Profit Potential of Energy Storage in a Car Park Using Electrolysis, Hydrogen Storage and Fuel Cell Electric Vehicles

years. The results for different load profiles show that higher electricity consumption leads to higher profits, as the power production potential rises. Because the mixed load profile matches better with VRE output than the residential load profile, the arbitrage potential is lower, which is in line with the results from [6]. The impact of the bid ladder price level on net profit is the highest of the six energy market inputs. Because the bid ladder directly determines the electricity prices, the gross profit per MWh increases by $25 € / \mathrm{MWh}$ if the bid ladder shifts upward by the same value.
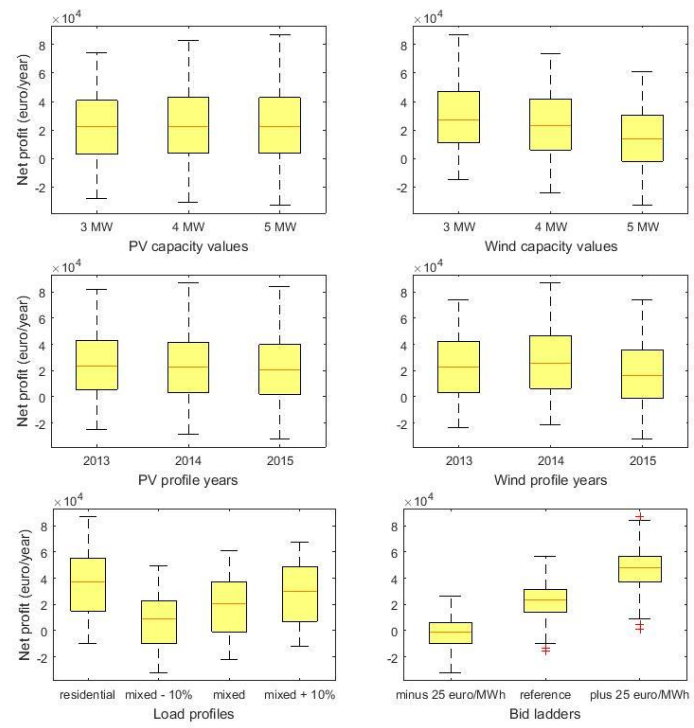

Figure 2. Sensitivity of CPPP profitability to energy market conditions

\section{Discussion}

The CPPP energy storage business model has been found to be profitable for a power system that is dominated by wind and solar power, as energy storage is highly valuable in such a system. CPPP profitability will depend for an important part on electricity prices at times of low VRE output. These prices will depend on the scarcity and operating costs of back-up power generation capacity and flexible load, but also on the degree to which providers of back-up capacity recover capital costs through energy sales at shortage hours.

The profitability of the CPPP business model may be enhanced by the inclusion of more services, such as the sale of hydrogen to FCEV drivers, and by the sale of the oxygen produced in the electrolysis process. Moreover, the CPPP reduces back-up power 
$10^{\mathrm{TH}}$ INTERNATIONAL CONFERENCE ON SUSTAINABLE ENERGY AND ENVIRONMENTAL Protection (June $27^{\mathrm{TH}}-30^{\mathrm{TH}}, 2017$, Bled, SLOVEnia), ENERGy Storage

R. van der Veen, R. Verzijlbergh, Z. Lukszo \& A. van Wijk: Exploring the Profit Potential of Energy Storage in a Car Park Using Electrolysis, Hydrogen Storage and Fuel

investment costs and causes lower local air pollution and noise (although it may prove difficult for the car park operator to capitalise on these benefits).

Valuable extensions of this work include the evaluation of the impact of electricity sale by the CPPP operator on the electricity market prices, and of the impact of limited availability of FCEVs (i.e., taking into account driving patterns).

\section{Conclusion}

This study provides preliminary results of an optimisation study in which the profit potential of a Car Park as Power Plant energy storage business model has been explored. Based on these results, we can conclude that the CPPP business model has the potential to be profitable in power systems with a high share of wind and solar power, but that the level of profitability highly depends on the electricity prices during VRE shortage hours.

\section{Notes}

1 The minimum bid ladder prices (and thus electricity prices) are $34.9,59.9$ and $84.9 € / \mathrm{MWh}$, respectively. The maximum bid ladder prices are $210.5,235.5$ and $260.5 € / \mathrm{MWh}$, respectively.

2 Because the break-even value depends on the arbitrage potential provided by the generation and load patterns, it varies between scenarios.

\section{References}

[1] M. Ball and M. Wietschel, eds., The hydrogen economy: opportunities and challenges. Cambridge University Press, 2009.

[2] A.J.M. van Wijk and L. Verhoef, Our car as power plant. IOS Press, 2014.

[3] F. Alavi, E.H. Park Lee, N. van de Wouw, B. de Schutter, and Z. Lukszo, "Fuel cell cars in a microgrid for synergies between hydrogen and electricity networks," Applied Energy, vol. 192, pp. 296-304, April 2017.

[4] V. Oldenbroek, L. Verhoef, and A.J.M. van Wijk, "Fuel cell electric vehicle as a power plant: Fully renewable integrated transport and energy system design and analysis for smart city areas," International Journal of Hydrogen Energy, vol. 42, pp. 8166-8196, March 2017.

[5] E.H. Park Lee and Z. Lukszo, "Scheduling FCEVs as power plants in a community microgrid," presented at IEEE PES Innovative Smart Grid Technologies Conference Europe (ISGT Europe), Ljubljana, 2016, pp. 1-6.

[6] N. Voulis, M. Warnier, and F.M.T. Brazier, "Impact of Service Sector Loads on Renewable Resource Integration," submitted for review, 2017, accessible at https://arxiv.org/abs/1605.09667.

[7] Renewables.ninja, PV and wind turbine power generation data, https://www.renewables.ninja, downloaded on 05.04.2017.

[8] TenneT, Dutch balancing market data, http://www.tennet.org/bedrijfsvoering/xmldownloads/index.aspx, downloaded on 25.03.2017. 
172 10 $10^{\mathrm{TH}}$ International Conference On Sustainable EnERgy and Environmental Protection (June $27^{\mathrm{TH}}-30^{\mathrm{TH}}, 2017$, BLed, Slovenia), Hydrogen AND Fuel Cells R. van der Veen, R. Verzijlbergh, Z. Lukszo \& A. van Wijk: Exploring the Profit Potential of Energy Storage in a Car Park Using Electrolysis, Hydrogen Storage and Fuel Cell Electric Vehicles

[9] Department of Energy (DOE), Fuel Cell Technologies Office Multi-Year Research, Development, and Demonstration Plan, Report, 2015. 
$10^{\mathrm{TH}}$ INTERNATIONAL CONFERENCE ON Sustainable ENERgy AND ENVIRONMENTAL Protection (June $27^{\mathrm{TH}}-30^{\mathrm{TH}}$, 2017, Bled, Slovenia), Hydrogen ANd Fuel Cells

J. Krope, A.Ghani Olabi, D. Goričanec \& S. Božičnik

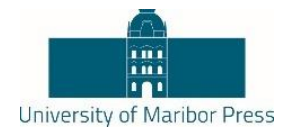

\title{
Investigation on the Coupling of Fuel Cell with Photovoltaic and Parabolic Trough Solar Systems
}

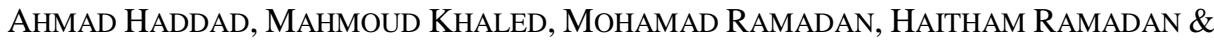 \\ MOHAMAD BECHERIF
}

\begin{abstract}
The present paper call into question combination of solar energy systems with Fuel cell. Indeed, fuel cells are green storage systems without any pollution effects. They are supplied by oxygen and hydrogen to produce electricity. That said, it is inescapable to find a source of hydrogen in order to use fuel cell. Several techniques can be adopted to produce hydrogen depending on the availability and the cost of the sources. One of the most utilized techniques is electrolysers. They allow to obtain hydrogen from water by several technologies among them proton exchange membrane (PEM) which is considered in context of this work. Electrolysers need electrical power to operate. With this in mind, a full green energy system can be constructed by using a renewable energy source to supply electrolysers. In the light of this framework, a comparison between two solar systems (Photovoltaic and Parabolic Trough) coupled to fuel cell is performed. The study shows the performance of each of both combined systems for different parameters and proposes recommendations depending on the considered configuration.
\end{abstract}

Keywords: • Hybrid Renewable Energy • Fuel Cell • Hydrogen Energy Storage $\bullet$ Photovoltaic $\bullet$ Solar Thermal $\bullet$ Optimum Coupling •

Correspondence Address: Ahmad Haddad, Ph.D., Assistant Professor, Lebanese International University, School of Engineering, Electrical Department, PO Box 146404 Beirut, Lebanon, email: ahmad.haddad@liu.edu.lb. Mahmoud Khaled, Ph.D., Associate Professor, Lebanese International University, School of Engineering, Mechanical Department, PO Box 146404 Beirut, Lebanon, e-mail: mahmoud.khaled@liu.edu.lb. Mohamad Ramadan, Ph.D., Assistant Professor, Lebanese International University, School of Engineering, Mechanical Department, PO Box 146404 Beirut, Lebanon, e-mail: mohamad.ramadan@liu.edu.lb. Haitham Ramadan, Ph.D., Assistant Professor, Zagazig University, Faculty of Engineering, Electrical Power and Machines Department., 44519, Zagazig, Egypt, e-mail: haitham.s.ramadan@gmail.com. Mohamad Becherif, Ph.D., Associate Professor, Université de Technology de Belfort-Montbéliard, Fuel Cell Laboratory, 90010 Belfort cedex, France, e-mail: mohamed.becherif@utbm.fr. 
$10^{\mathrm{TH}}$ InTERnATIONAL CONFERENCE ON Sustainable ENERgy AND ENVIRONMENTAL Protection (June $27^{\mathrm{TH}}-30^{\mathrm{TH}}, 2017$, Bled, Slovenia), Hydrogen and Fuel Cells A. Haddad, M. Khaled, M. Ramadan, H. Ramadan \& M. Becherif: Investigation on the Coupling of Fuel Cell with Photovoltaic and Parabolic Trough Solar Systems

In the last decades, the domain of energy has undergone a huge revolution. Indeed, the current energy crisis has many aspects among them are the high cost of fuel, the depletion of fuel reserve and the pollution. Traditionally the focus of energy studies, concerns mainly the economical dimension. Nonetheless, the dangerous level of pollution has shed light on the environmental impact of the crisis. On the other hand, a simple anatomy of any energy supply strategy lead to two fundamental parts. Energy source and energy storage. Huge efforts have been concentrated to find green sources of energy. To put it another way, finding renewable and sustainable sources such as solar energy [1-2]. Other works concern energy recovery [3-4] and energy storage such as batteries and supercapacitors. Fuel cell [5-7] can be seen as green energy storage system since it is pollution free device. Green-Green energy system can be constructed by coupling renewable energy source and fuel cell. In the light of green-green concept, several studies have been proposed to investigate the coupling of fuel cell with renewable resources especially solar energy systems. Several solar-fuel cell coupling strategies have been devoted for vehicles [8-9] applications. Other studies concerns coupling solar-fuel cell with other renewable resources such as wind energy system. For instance, in [10] the authors propose a management approach for multi energy sources applications and present wind-solar-fuel cell coupling. In [11], an economical study on using biomass gasifier with solar-fuel cell coupled system is shown. Other works examine case study for specific regions such as in [12] where the authors apply an optimization algorithm on the case of El Paso city. A thermodynamic approach is discussed in [13], the authors perform a case study on the city of Toronto. In spite of the fact that the majority of solar-fuel cell coupling studies concern photovoltaic solar systems some works are dedicated to present coupling fuel cell with other types of solar systems such as thermal solar system. In [14] a system coupling fuel cell and solar chimney is investigated. Ramadan et al [15] present a model coupling parabolic trough and fuel cell as well as the sizing procedure. The present paper call into question, comparison between two different approaches of coupling solar energy and fuel cell: Photovoltaic-Fuel cell and Thermal Solar-Fuel cell. The aim is to identify the better coupling approach for an imposed criterion. The remaining of the paper is organized as follows:

Section two is devoted to present the general procedure of coupling. Modeling of PV, TS, Electrolyzer and FC are presented in section three. Results are discussed in section four and concluding remarks are presented in the last section.

\section{Procedure of Optimization}

Coupling solar energy and Fuel cell is performed indirectly through electrolyzer. Indeed, Fuel cell is supplied by hydrogen to provide electricity. That is why it is unescapable to find a source of hydrogen in order to use fuel cell. Several techniques can be adopted to produce hydrogen depending on the availability and the cost of the sources. One of the most utilized techniques are electrolyzers. They allow to obtain hydrogen from water by several technologies among them proton exchange membrane (PEM) which is considered 
$10^{\mathrm{TH}}$ INTERNATIONAL CONFERENCE ON SUSTAINABLE ENERGY AND ENVIRONMENTAL Protection (June $27^{\mathrm{TH}}-30^{\mathrm{TH}}, 2017$, Bled, SLOVEnia), ENERGy StORAGE

A. Haddad, M. Khaled, M. Ramadan, H. Ramadan \& M. Becherif: Investigation on the Coupling of Fuel Cell with Photovoltaic and Parabolic Trough Solar Systems

in this work. Having said that, electrolyzers need electrical power to operate. A full green energy system can be constructed by using a renewable energy source to supply electrolyzers. When solar energy is adopted to produce hydrogen. The two main technologies that can be utilized are photovoltaic cell and thermal solar system. The output power delivered by each system varies depending on specific parameters. With this in mind, the optimum solar-fuel cell coupling requires to define a calculation procedure that converges toward the optimal design. Notwithstanding, a decision criterion should be imposed. To this end several criteria could be adopted depending on the objective of the application. In the shade of this paper three criteria are presented. Total Energy, Minimum Threshold and Maximum Power Fixed Period. Total Energy is the most generalized criterion since it represents the net provided energy regardless the minimum or maximum power that may be obtained by zooming on a specific period of time. By contrast Minimum Threshold does not compare the total energy, it identifies globally the most secured system or in other words the design that provides a power supply greater than a minimum limit. That said, the third criterion or Maximum Power Fixed Period is dedicated for application where maximum power is needed for a determined period of time regardless the total energy supplied over the year.

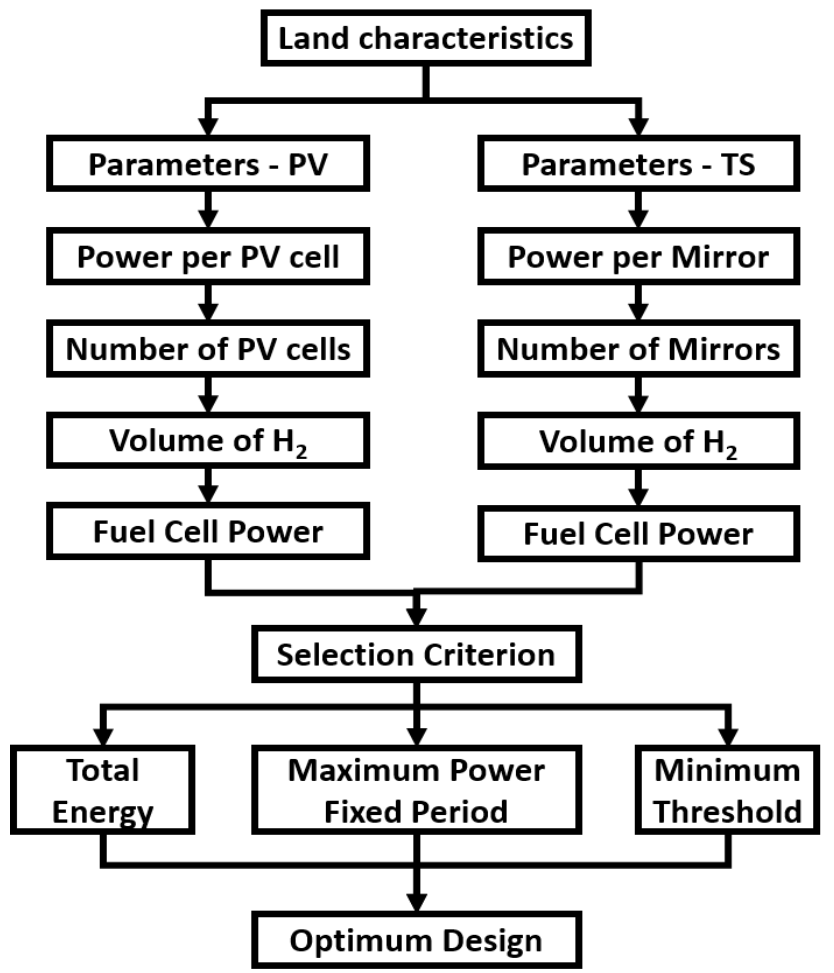

Figure 1. Procedure of optimization 
$10^{\mathrm{TH}}$ InTERnATIONAL CONFERENCE ON Sustainable ENERgy AND ENVIRONMENTAL Protection (June $27^{\mathrm{TH}}-30^{\mathrm{TH}}, 2017$, Bled, Slovenia), Hydrogen and Fuel Cells A. Haddad, M. Khaled, M. Ramadan, H. Ramadan \& M. Becherif: Investigation on the Coupling of Fuel Cell with Photovoltaic and Parabolic Trough Solar Systems

The scenario considered in this work, consists on sizing and modeling the PV array system based on a preset land area. This section is divided into two parts: The first part deals with the PV array sizing according to the effective land area, the PV module tilt angle at the selected location, and to the system's DC bus voltage. The second part include the mathematical modeling aiming to calculate the PV array output power with respect to the Direct Normal Insulation $(D N I)$ of the selected location and the number of PV modules.

\subsection{PV array sizing}

In this part, a rectangular land of $1000 \mathrm{~m}^{2}$ area is considered. The location studied is

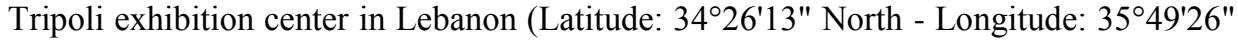
East). Solar insulation data for the selected location are taken from the Photovoltaic Geographical Information System (PVGIS). According to these data, the optimal tilt angle for the selected place is $\theta_{\text {optimal }}=30^{\circ}$. This is close to the mean tilt angle $\theta_{\text {mean }}=34^{\circ}$ calculated in Table 1 . The PV module used in the array design is the Sunmodule SW 250 mono. Its characteristics are given in the Table 2.

Table 1. Mean tilt angle of the PV module

\begin{tabular}{|c|c|c|c|}
\hline Date & $\begin{array}{c}\text { Latitude } \\
\phi\end{array}$ & $\begin{array}{l}\text { Declinatio } \\
\mathbf{n} \text { angle of } \\
\text { the sun } \delta\end{array}$ & $\begin{array}{c}\text { PV module } \\
\text { tilt angle } \\
\theta=\phi-\delta\end{array}$ \\
\hline Dec. $21^{\text {st }}$ & $34^{\circ}$ & $-23^{\circ}$ & $57^{\circ}$ \\
\hline Mar. $20^{\text {th }}$ & $34^{\circ}$ & $0^{\circ}$ & $34^{\circ}$ \\
\hline Jun. $21^{\text {st }}$ & $34^{\circ}$ & $+23^{\circ}$ & $11^{\circ}$ \\
\hline Sep. $23^{\text {rd }}$ & $34^{\circ}$ & $0^{\circ}$ & $34^{\circ}$ \\
\hline & & & $\theta_{\text {mean }}=34^{\circ}$ \\
\hline
\end{tabular}

Table 2. PV module characteristics

\begin{tabular}{|l|c|}
\hline Description & Rating \\
\hline Rated power & $P_{\max }=250 \mathrm{~W}$ \\
\hline Open circuit voltage & $V_{O C}=37.8 \mathrm{~V}$ \\
\hline Max. power point voltage & $V_{M P}=31.1 \mathrm{~V}$ \\
\hline Short circuit current & $I_{S C}=8.28 \mathrm{~A}$ \\
\hline Max. power point current & $I_{M P}=8.05 \mathrm{~A}$ \\
\hline Dimensions & $167.5 \mathrm{~cm} \times 95.1 \mathrm{~cm}$ \\
\hline
\end{tabular}

To avoid shading in solar array, a minimum spacing distance $\mathrm{D}$ between modules is required as shown in Figures 1 and 2. The shadow distance D is found through using simple trigonometry as follows: 
A. Haddad, M. Khaled, M. Ramadan, H. Ramadan \& M. Becherif: Investigation on the Coupling of Fuel Cell with Photovoltaic and Parabolic Trough Solar Systems

$D=\frac{h \times \cos \left(\psi-180^{\circ}\right)}{\tan (\alpha)}$

where, $h$ is the height of obstruction calculated from the tilted module length $x$ and the PV module tilt angle $\theta$ as shown in Figure $1, \alpha$ is the solar altitude angle and $\psi$ the solar azimuth angle as shown in Figure 3.

$h=x \times \sin (\theta)$

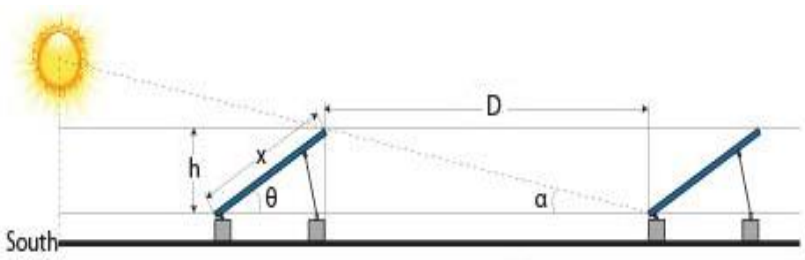

Figure 2. Shadow distance

Given the module length $x=167.5 \mathrm{~cm}$, the tilt angle $\theta_{\text {optimal }}=30^{\circ}$, the solar altitude angle considered at the end of the effective sun hours in the worst day of the year (Dec. $\left.21^{\text {st }}\right) \alpha=20^{\circ}$ and the solar azimuth angle under the same conditions $\psi=229^{\circ}$, the shadow distance $\mathrm{D}$ is:

$D=\frac{167.5 \sin \left(30^{\circ}\right) \cos \left(229^{\circ}-180^{\circ}\right)}{\tan \left(20^{\circ}\right)}=149 \mathrm{~cm}$

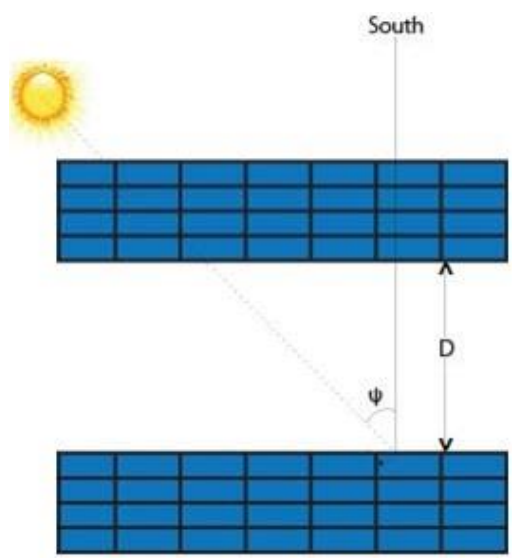

Figure 3. Solar azimuth angle

Based on the shadow distance D, the PV module dimensions and the optimal tilt angle, the maximum number of PV modules that can fit in $1000 \mathrm{~m}^{2}$ land area is $N_{P V}=200$ modules. The number of modules in series $N_{P V \text {-series }}$ is the ratio of the array's DC voltage $V_{D C-A r r a y}$ over the module's maximum power point voltage $V_{O C}$ rounded to the 
$10^{\mathrm{TH}}$ InTERnATIONAL CONFERENCE ON Sustainable ENERgy AND ENVIRONMENTAL Protection (June 27 $7^{\mathrm{TH}}-30^{\mathrm{TH}}, 2017$, Bled, SLovenia), Hydrogen ANd Fuel Cells

A. Haddad, M. Khaled, M. Ramadan, H. Ramadan \& M. Becherif: Investigation on the Coupling of Fuel Cell with Photovoltaic and Parabolic Trough Solar Systems

next higher integer. To be compatible with the electrolyzer's DC input voltage, we consider $V_{D C \text {-Array }}=150 \mathrm{~V}$. Therefore,

$N_{P V \text {-Series }}=\left.\frac{V_{D C-\text { Array }}}{V_{O C}}\right|_{\text {Rounded }}=5$ Modules

Hence, the number of modules in parallel $N_{P V \text {-Parallel }}$ is:

$N_{P V-\text { Parallel }}=\frac{N_{P V}}{N_{P V-S e r i e s}}=40$ Modules

Figure 4 shows the PV array configuration inside the $1000 \mathrm{~m}^{2}$ land area.

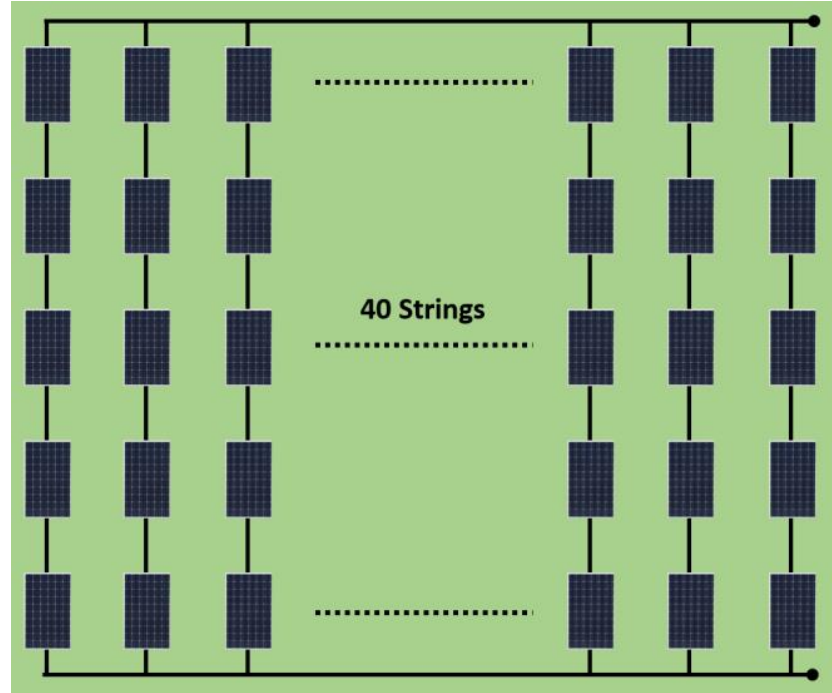

Figure 4. PV array configuration

\subsection{PV array mathematical modeling}

To elaborate the mathematical modeling of the PV array, we propose to represent the module by the equivalent electrical circuit shown in Figure 5. In fact, the PV module can be seen as a dependent current source controlled by Direct Normal Insulation $(D N I)$. This notion is modeled as a photocurrent $I_{P H}$. Besides, the module is composed of $60 \mathrm{PN}$ junction cells in series which behave as Diode. The movement of current through the emitter and base of the solar cell, the contact resistance between the metal contact and the silicon and the resistance of the top and rear metal contacts cause a drop in the module's voltage. A series resistance $R_{S}$ is used to represent this drop. In addition, manufacturing defects cause some power loss that is represented with a shunt resistance $R_{S H}$ in parallel. 
A. Haddad, M. Khaled, M. Ramadan, H. Ramadan \& M. Becherif: Investigation on the Coupling of Fuel Cell with Photovoltaic and Parabolic Trough Solar Systems

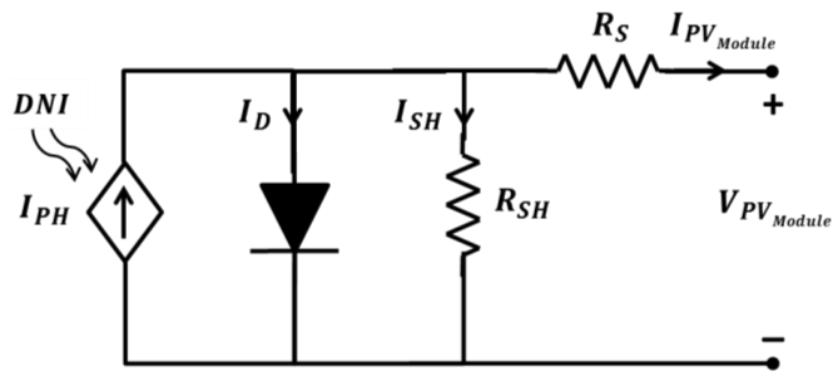

Figure 5. PV module equivalent circuit

The mathematical model of the entire array is given by the block diagram in Figure 6 . The main inputs are the $D N I$, the module's temperature $T_{M}$, the number of series modules in one string $N_{P V \text {-Series }}$, the number of parallel strings in the array $N_{P V \text {-Parallel }}$, as well as the module's operating voltage $V_{P V_{\text {Module }}}$. The latter is considered as input because it is set by the controller so that to extract maximum power from the module. The outputs are PV array's voltage, current and power.

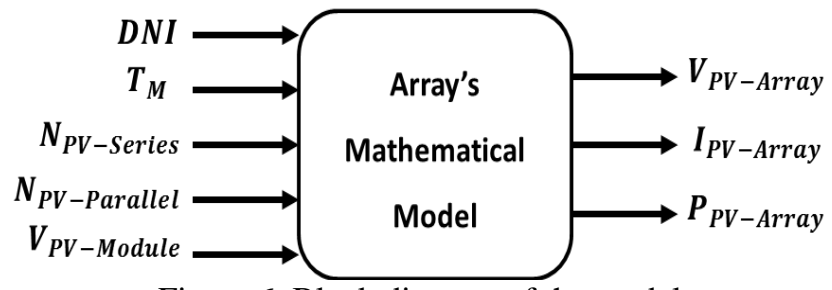

Figure 6. Block diagram of the model

According to the circuit in Figure 5, the module's output current is:

$I_{P V_{\text {Module }}}=I_{P H}-I_{D}-I_{S H}$

with $I_{P H}$ : Module's photocurrent given by:

$I_{P H}=\left[I_{S C}+K_{i}\left(T_{M}-T_{r e f}\right)\right] \times \frac{D N I}{1000}$

$I_{D}$ : Module's diode current given by:

$I_{D}=I_{S}\left[\exp \left(q \times \frac{V_{P V_{\text {Module }}}{ }^{R_{S} I_{P} V_{\text {Module }}}}{K n T_{M}}\right)-1\right]$ 
$180 \quad 10^{\mathrm{TH}}$ International Conference on Sustainable EnERgy and EnVIRONMENTAL Protection (June $27^{\mathrm{TH}}-30^{\mathrm{TH}}, 2017$, BLed, Slovenia), Hydrogen and Fuel Cells

A. Haddad, M. Khaled, M. Ramadan, H. Ramadan \& M. Becherif: Investigation on the Coupling of Fuel Cell with Photovoltaic and Parabolic Trough Solar Systems

$I_{S H}$ : Module's current loss caused by its shunt resistance $R_{S H}$. It is given by:

$I_{S H}=\frac{V_{O C}}{R_{S H}}$

$K_{i}:$ Temperature coefficient.

$T_{\text {ref }}:$ Reference temperature.

$I_{S}:$ Module's saturation current.

$I_{R S}:$ Module's reverse saturation current.

$q$ : Quantity of electronic charge.

$E_{g}$ : Energy band gap for the monocrystalline Silicon used in the PV module.

$n$ : Module's ideality factor.

$K$ : Boltzmann's constant.

$R_{S}$ : Equivalent series resistance of the module.

The total output voltage of the PV array is:

$V_{P V_{\text {Array }}}=N_{P V \text {-Series }} \times V_{P V_{\text {Module }}}$

The total output current of the PV array is:

$I_{P V_{\text {Array }}}=N_{P V-\text { Parallel }} \times I_{P V_{\text {Module }}}$

The total output power of the PV array is:

$P_{P V_{\text {Array }}}=V_{P V_{\text {Array }}} \times I_{P V_{\text {Array }}}$

\section{$4 \quad$ Electrolyzer Sizing and Modeling}

To meet the load demand at night and during periods of low insulation, energy storage is essential. Conventional battery bank concept used in small scale projects do not apply in case of large power generation. Indeed, controlling the state of charge of a big battery bank to protect it against overcharge/overdischarge is a challenging problem. Furthermore, batteries' lifetime is limited and harmfully affected with temperature increase. Moreover, they are not environmentally friendly. For all these reasons we propose to use hydrogen production as a storage medium. For this end, we use an electrolyzer of $18 \mathrm{~kW}$ rated power and $150 \mathrm{~V}$ DC voltage. The electrolyzer is sized based on the maximum DC power produced by the PV array and the Parabolic Trough (PT) system in June with an additional $20 \%$ security margin. The hydrogen and oxygen production rates $\dot{m}_{\mathrm{H}_{2}}$ and $\dot{m}_{\mathrm{O}_{2}}$ are:

$\dot{m}_{H_{2}}=2 \dot{m}_{O_{2}}=\frac{n_{\text {cells }} \times i_{E} \times \eta_{F}}{2 F} \times 3600 \times \frac{M_{H_{2}}}{\rho_{H_{2}}}$ 
A. Haddad, M. Khaled, M. Ramadan, H. Ramadan \& M. Becherif: Investigation on the Coupling of Fuel Cell with Photovoltaic and Parabolic Trough Solar Systems

with $n_{\text {cells }}$ : Number of electrolyzer's cells.

$F$ : Faraday's constant.

$M_{H_{2}}$ : Molar mass of hydrogen.

$\rho_{\mathrm{H}_{2}}$ : Density of hydrogen.

$\eta_{F}$ : Faraday's efficiency given by:

$\eta_{F}=96.5 \times \exp ^{\left(\frac{0.09}{i_{E}}-\frac{75.5}{i_{E}^{2}}\right)}$

$i_{E}$ : Electrolyzer's current given by:

$i_{E}=\frac{P_{P V} \text { Array }}{150 \mathrm{~V}}(P V$ case $)$

$i_{E}=\frac{P_{P T} \times \eta_{\text {Rectifier }}}{150 \mathrm{~V}}(P T$ case $)$

$\eta_{\text {Rectifier }}$ : Rectifier's efficiency. In case of PT, the AC power is converted to DC using a rectifier.

\section{$5 \quad$ Fuel Cell Sizing and Modeling}

Hydrogen and oxygen produced by the electrolyzer are used to feed the Fuel Cell system for power generation in absence of solar radiations. The fuel cell's output current is function of hydrogen consumption rate as shown in the following equation:

$i_{F C}=\frac{2 F \times \dot{m}_{H_{2}}}{3600} \times \frac{\rho_{H_{2}}}{M_{H_{2}}}$

The output voltage per cell is:

$V_{\text {cell }}=E_{\text {nernst }}-V_{\text {act }}-V_{\text {ohm }}-V_{\text {conc }}$

with $E_{\text {nernst }}$ : Open circuit voltage.

$V_{a c t}$ : Activation voltage loss given by:

$V_{a c t}=\frac{R_{G} T_{F C}}{2 F} \times \ln \left(\frac{i_{F C}}{i_{0}}\right)$

$R_{G}:$ Gas constant.

$T_{F C}$ : Fuel cell temperature.

$i_{0}$ : Exchange Current.

$V_{\text {ohm }}$ : Ohmic voltage loss given by: 
$18210^{\mathrm{TH}}$ InTERnational CONFERENCE ON Sustainable ENERGY AND ENVIRONMENTAL Protection (June $27^{\mathrm{TH}}-30^{\mathrm{TH}}, 2017$, Bled, Slovenia), Hydrogen and Fuel Cells A. Haddad, M. Khaled, M. Ramadan, H. Ramadan \& M. Becherif: Investigation on the Coupling of Fuel Cell with Photovoltaic and Parabolic Trough Solar Systems

$V_{\text {ohm }}=\left(R_{A}+R_{M}+R_{C}\right) \times i_{F C}$

$R_{A}:$ Anode electrical resistance.

$R_{C}$ : Cathode electrical resistance.

$R_{M}$ : Membrane electrical resistance.

$V_{\text {conc }}$ : Concentration voltage loss given by:

$V_{\text {conc }}=\frac{R_{G} T_{F C}}{2 F} \times \ln \left(1-\frac{i_{F C}}{i_{\max }}\right)$

$i_{\text {max }}:$ Limit Current.

The fuel cell's output power is:

$P_{F C}=V_{F C} \times i_{F C}=N_{\text {cells }} \times V_{\text {cell }} \times i_{F C}$

$N_{\text {cells }}:$ Number of cells.

The fuel cell is sized according to its maximum limit current density as well as to the inverter's input DC voltage. Based on experimental works, the maximum limit current density $j_{\max }$ of the fuel cell is $0.7 \mathrm{~A} / \mathrm{cm}^{2}$ and the minimum guaranteed fuel cell's output voltage is $0.6 \mathrm{~V} / \mathrm{cell}$. According to the maximum DC power produced by the PV array and the PT system in June with an additional $20 \%$ security margin, the fuel cell's maximum current is $192 A$. Therefore, the cell's area is:

$A_{\text {cell }}=\frac{192 \mathrm{~A}}{0.7 \mathrm{~A} / \mathrm{cm}^{2}} \approx 275 \mathrm{~cm}^{2}$

The DC input voltage of a conventional 220V AC inverter is $48 \mathrm{VDC}$. Hence, the number of cells is:

$N_{\text {cells }}=\frac{48 \mathrm{~V}}{0.6 \mathrm{~V} / \mathrm{cell}}=80 \mathrm{cells}$

\section{$6 \quad$ Parabolic Trough Sizing and Modeling}

The received solar energy can be calculated as follows:

$$
\dot{Q}_{\text {absorbed }}=P_{\text {SUN }} \cdot P_{\text {PERFORMANCE }} \cdot P_{\text {CONFIGURAT ION }}
$$

where $P_{\text {SUN }}, P_{\text {PERFORMANCE }}$ and $P_{\text {CONFIGURATION }}$ represent respectively parameters of sun irradiance, parameters of performance and parameters of system configuration.

$$
P_{S U N}=D N I \cdot \cos \theta \cdot I A M
$$


$10^{\mathrm{TH}}$ INTERNATIONAL CONFERENCE ON SUSTAINABLE ENERGY AND ENVIRONMENTAL Protection (June $27^{\mathrm{TH}}-30^{\mathrm{TH}}, 2017$, Bled, SLovenia), EnERgy Storage

A. Haddad, M. Khaled, M. Ramadan, H. Ramadan \& M. Becherif: Investigation on the Coupling of Fuel Cell with Photovoltaic and Parabolic Trough Solar Systems

where the direct normal insulation $D N I$ represents the portion of solar radiation that reaches the surface of the earth. It depends generally on time period of the year and location. IAM is the incidence angle modifier and $\theta$ is the angle of incidence.

$$
P_{\text {PERFORMANCE }}=\text { Rowshadow. Endloss. } \eta_{\text {field }} \cdot \eta_{H C E}
$$

where Rowshadow accounts for mutual shading. Endloss accounts for losses from ends of the receiver tubes or Heat Collection Elements HCE. $\eta_{\text {field }}$ is an efficiency that represents losses due to mirrors' imperfections. $\eta_{H C E}$ is an efficiency that represents HCEs' imperfections.

$$
P_{\text {CONFIGURATION }}=S F_{a} \cdot A
$$

where $A$ is the area of the tube and $S F_{a}$ is the fraction of the solar field tracking the sun. The angle of incidence is written:

$$
\cos \theta=\sqrt{\cos ^{2} \theta_{z}+\cos ^{2} \delta \sin ^{2} w}
$$

where $w$ represents the hour angle obtained from:

$$
\cos \theta_{z}=\cos \delta \cos \phi \cos w+\sin \delta \sin \phi
$$

where $\emptyset$ is the latitude. IAM accounts for the additional reflection and absorption losses due to the increase of the angle of incidence:

$$
\begin{aligned}
& I A M=\frac{K}{\cos \theta} \\
& K=\cos \theta+0.000884 \theta+0.00005369 \theta^{2}
\end{aligned}
$$

The Rowshadow reduces the performance of the collector by reducing the amount of radiation incident:

$$
\text { Rowshadow }=\frac{L_{\text {spacing }}}{W} \frac{\cos \theta_{z}}{\cos \theta}
$$

where $W$ represents the collector aperture width and $L_{\text {spacing }}$ represents the spacing length between troughs. Endlosses are characterized by the Endloss factor can be determined as follows: 
184 10 $10^{\mathrm{TH}}$ InTERnational CONFERENCE ON Sustainable EnERgy and EnVIRONMENTAL Protection (June $27^{\mathrm{TH}}-30^{\mathrm{TH}}, 2017$, BLed, Slovenia), Hydrogen AND Fuel Cells A. Haddad, M. Khaled, M. Ramadan, H. Ramadan \& M. Becherif: Investigation on the Coupling of Fuel Cell with Photovoltaic and Parabolic Trough Solar Systems

Endloss $=1-\frac{f \tan \theta}{L_{S C A}}$

where $f$ represents the focal length and $L_{S C A}$ represents the length of single collector assembly. The output electrical power obtained from one mirror is written:

$P_{\text {mirror }}=\dot{Q}_{\text {absorbed }} \cdot \eta_{\text {thermal }} \cdot \eta_{\text {electrical }}$

where $\eta_{\text {thermal }}$ is the thermal efficiency of the cycle and $\eta_{\text {electrical }}$ represents the electrical efficiency.

\section{$7 \quad$ Simulation Results}

\subsection{Comparing yearly AC power for PV and PT}

The PT output power is AC while the one of PV is DC. In order to compare the two systems, an inverter is used to convert the DC power of the PV array to an AC one. The $\mathrm{AC}$ output power of the inverter is:

$P_{\text {Inverter }}=P_{P V_{\text {Array }}} \times \eta_{\text {Inverter }}$

with $\eta_{\text {Inverter }}$ : The inverter's efficiency.

Figure 7 presents the yearly AC power variation for both PV and PT systems based on DNI data for the studied location. 
$10^{\mathrm{TH}}$ INTERNATIONAL CONFERENCE ON SUSTAINABLE ENERGY AND ENVIRONMENTAL Protection (June $27^{\mathrm{TH}}-30^{\mathrm{TH}}, 2017$, Bled, SLovenia), EnERgy Storage

A. Haddad, M. Khaled, M. Ramadan, H. Ramadan \& M. Becherif: Investigation on the Coupling of Fuel Cell with Photovoltaic and Parabolic Trough Solar Systems

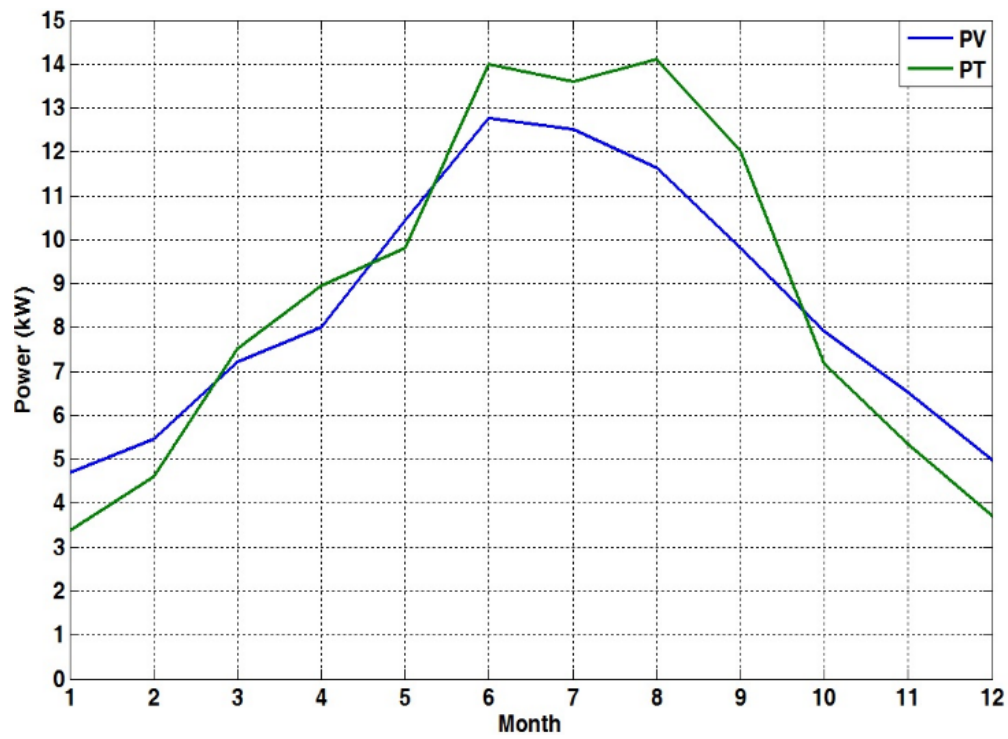

Figure 7. Yearly AC power variation - PV/PT

Results in Figure 7 show that there is no absolute advantage of one technology on the other. In fact, from the end of September to the end of February the PV power is greater than the one of PT. This latter exceeds the PV from the end of February to the end of September except few days in April and May. Hence, the choice between the two technologies depends on the selection criterion. If the criterion is the total energy, the two systems are nearly equivalent with a negligible advantage for the PT. If the criterion is a minimum threshold power around $5 \mathrm{~kW}$, the advantage is for the PV. Finally if the criterion is to have maximum power during the summer period, the advantage is for the PT.

\subsection{Comparing yearly hydrogen production rate for PV and PT}

The DC power of PV is directly used to produce hydrogen while AC power of PT needs to be converted to DC using a rectifier. This gives advantage for PV over PT regarding hydrogen production. In case of PT, hydrogen production rate will be function of the rectifier's efficiency $\eta_{\text {Rectifier }}$. This conclusion is proved through results in Figure 8 that compare between PV and PT hydrogen production rates. 
$10^{\text {TH }}$ International Conference on Sustainable Energy and Environmental Protection (June $27^{\mathrm{TH}}-30^{\mathrm{TH}}, 2017$, Bled, Slovenia), Hydrogen and Fuel Cells

A. Haddad, M. Khaled, M. Ramadan, H. Ramadan \& M. Becherif: Investigation on the Coupling of Fuel Cell with Photovoltaic and Parabolic Trough Solar Systems

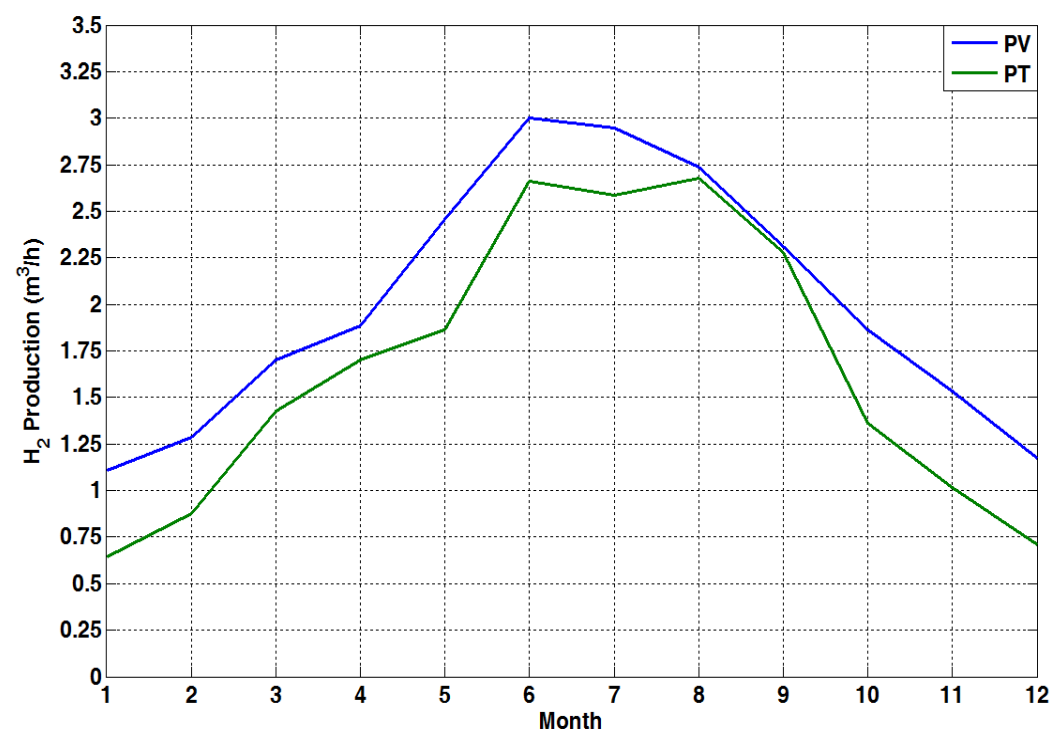

Figure 8 . Yearly $\mathrm{H}_{2}$ production rates - PV/PT

\subsection{Comparing yearly Fuel Cell power for PV and PT}

Since hydrogen production rate for PV is greater than the one of PT, the fuel cell output power will be greater in case of PV. This result is shown in Figure 9.

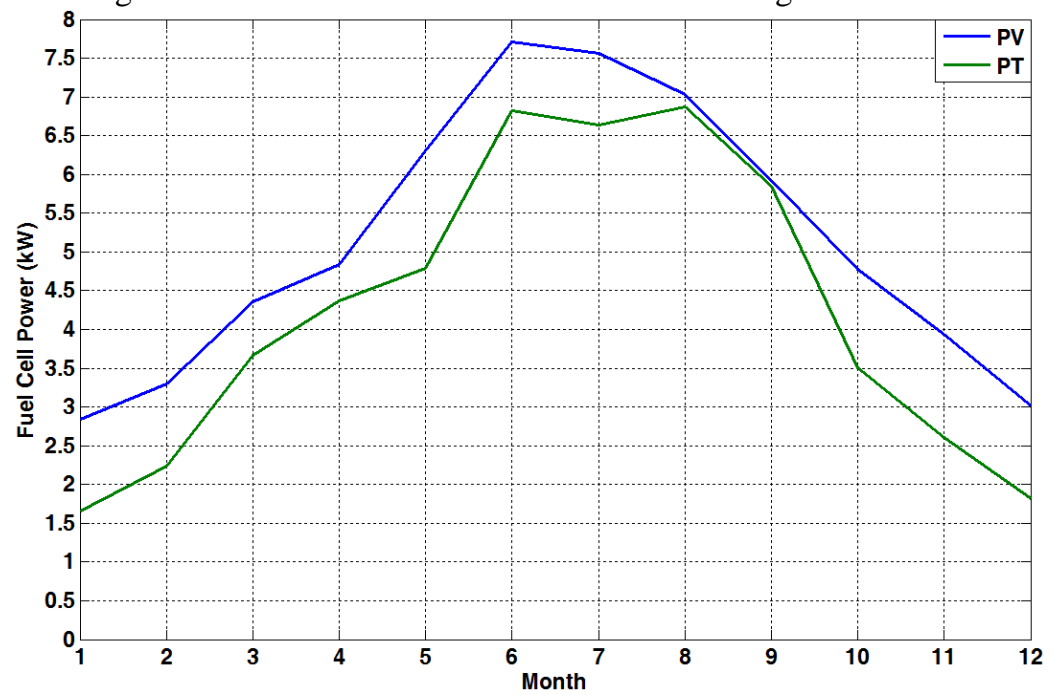

Figure 9. Yearly Fuel Cell output power 
$10^{\mathrm{TH}}$ INTERNATIONAL CONFERENCE ON SUSTAINABLE ENERGY AND ENVIRONMENTAL Protection (June $27^{\mathrm{TH}}-30^{\mathrm{TH}}, 2017$, Bled, SLovenia), EnERgy Storage

A. Haddad, M. Khaled, M. Ramadan, H. Ramadan \& M. Becherif: Investigation on the Coupling of Fuel Cell with Photovoltaic and Parabolic Trough Solar Systems

Therefore, PV has advantage on PT if coupled with Fuel Cell through hydrogen storage despite of the higher AC power of PT in summer. Energy storage in PT case might be more efficient if thermal storage is used in place of hydrogen storage.

\section{Conclusion}

The present work proposes a full green renewable energy system based on the coupling of Fuel Cell with PV or PT solar systems through hydrogen storage. The systems are sized according to the DNI data of the studied location with $1000 \mathrm{~m}^{2}$ of land area. Mathematical models for PV array, PT system, Fuel Cell and Electrolyzer are elaborated. Proposed models calculate the output power of each system as well as the produced quantity of hydrogen. A comparison between the output powers of the two solar systems based on yearly insulation data is carried-out. Results show that none of the two technologies is absolutely the best over the entire year. The optimum choice depends on the selection criterion which can be either the yearly total energy, or the minimum guaranteed threshold power, or the maximum power during a fixed period. Results reveal that both systems are nearly equivalent regarding the yearly produced energy. Furthermore, results indicate that PV ensures a better minimum threshold power of $5 \mathrm{~kW}$. However, if the criterion is to have maximum power during the summer period, the advantage is for the PT. This is due to the fact that PT is positively affected by temperature increase in summer while PV is negatively influenced by this increase. Finally, when coupled with Fuel Cell the PV generates more power because there is no need for a rectifier to produce hydrogen as in case of PT.

\section{References}

[1] Farouk Hachem, Bakri Abdulhay, Mohamad Ramadan, Hicham El Hage, Mostafa Gad El Rab, Mahmoud Khaled, Improving the performance of photovoltaic cells using pure and combined phase change materials - Experiments and transient energy balance, Renewable Energy, Volume 107, July 2017, Pages 567-575.

[2] Herez A, Ramadan M, Abdulhay B, Khaled M. Short review on solar energy systems. AIP Conference Proceedings 2016; 1758: 1- 10.1063/1.4959437.

[3] Ramadan M, Lemenand T, Khaled M. Recovering heat from hot drain waterExperimental evaluation, parametric analysis and new calculation procedure. Energy and Buildings 2016; 128: 575-58.

[4] Ramadan M, Gad El Rab M, Khaled M. Parametric analysis of air-water heat recovery concept applied to HVAC systems: Effect of mass flow rates. Case Studies in Thermal Engineering 2015; 6: 61-68.

[5] A. Benmouna, M. Becherif, D. Depernet, F. Gustin, H.S. Ramadan, S. Fukuhara, Fault diagnosis methods for Proton Exchange Membrane Fuel Cell system, International Journal of Hydrogen Energy, Volume 42, Issue 2, 12 January 2017, Pages 1534-1543.

[6] A. Saadi, M. Becherif, D. Hissel, H.S. Ramadan, Dynamic modeling and experimental analysis of PEMFCs: A comparative study, International Journal of Hydrogen Energy, Volume 42, Issue 2, 12 January 2017, Pages 1544-1557.

[7] R. Saadi, O. Kraa, M.Y. Ayad, M. Becherif, H. Ghodbane, M. Bahri, A. Aboubou, Dual loop controllers using PI, sliding mode and flatness controls applied to low voltage 
188 10 $10^{\mathrm{TH}}$ InTERnAtional CONFERENCE ON Sustainable ENERGy AND ENVIRONMENTAL Protection (June $27^{\mathrm{TH}}-30^{\mathrm{TH}}, 2017$, Bled, Slovenia), Hydrogen ANd Fuel Cells

A. Haddad, M. Khaled, M. Ramadan, H. Ramadan \& M. Becherif: Investigation on the Coupling of Fuel Cell with Photovoltaic and Parabolic Trough Solar Systems

converters for fuel cell applications, International Journal of Hydrogen Energy, Volume 41, Issue 42, 9 November 2016, Pages 19154-19163.

[8] E. Troncoso, N. Lapeña-Rey, O. Valero. Off-grid test results of a solar-powered hydrogen refuelling station for fuel cell powered Unmanned Aerial Vehicles. International Journal of Hydrogen Energy, Volume 39, Issue 21, 15 July 2014, Pages 11267-11278.

[9] M. Meratizaman, S. Monadizadeh, M. Amidpour, Simulation, economic and environmental evaluations of green solar parking (refueling station) for fuel cell vehicle. International Journal of Hydrogen Energy, Volume 39, Issue 5, 4 February 2014, Pages 2359-2373.

[10] S. Saravanan, S. Thangavel , Instantaneous reference current scheme based power management system for a solar/wind/fuel cell fed hybrid power supply. International Journal of Electrical Power \& Energy Systems, Volume 55, February 2014, Pages 155-170.

[11] A Singh, P Baredar, B Gupta, Computational Simulation \& Optimization of a Solar, Fuel Cell and Biomass Hybrid Energy System Using HOMER Pro Software. Procedia Engineering, Volume127, 2015, Pages 743-750.

[12] O. Joneydi Shariatzadeh, A.H. Refahi, S.S. Abolhassani, M. Rahmani, Modeling and optimization of a novel solar chimney cogeneration power plant combined with solid oxide electrolysis/fuel cell. Energy Conversion and Management, Volume 105, 15 November 2015, Pages 423-432.

[13] Pouria Ahmadi, Ibrahim Dincer, Marc A. Rosen. Transient thermal performance assessment of a hybrid solar-fuel cell system in Toronto, Canada. International Journal of Hydrogen Energy, Volume 40, Issue 24, 29 June 2015, Pages 7846-7854.

[14] O. Joneydi Shariatzadeh, A.H. Refahi, S.S. Abolhassani, M. Rahmani, Modeling and optimization of a novel solar chimney cogeneration power plant combined with solid oxide electrolysis/fuel cell. Energy Conversion and Management, Volume 105, 15 November 2015, Pages 423-432.

[15] Ramadan M, Khaled M, Ramadan H, Becherif M. Modeling and sizing of combined fuel cell-thermal solar system for energy generation. International Journal of Hydrogen Energy 2016; 41, 44: 19929-7. 
$10^{\mathrm{TH}}$ INTERNATIONAL CONFERENCE ON Sustainable ENERgy AND EnVironmental Protection (June $27^{\mathrm{TH}}-30^{\mathrm{TH}}, 2017$, BLed, Slovenia), Hydrogen ANd Fuel Cells

J. Krope, A.Ghani Olabi, D. Goričanec \& S. Božičnik

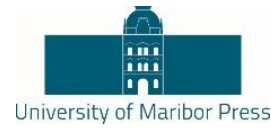

\title{
State-of-the-Art Manufacturing Technologies of PEMFC Components
}

\author{
AbDulrahman Alanazi, EMmanuel OgungBemi, AWORTwe WiLberforce, \\ OLUWATOSIN S. IJAODOLA, PARAG VICHARE \& ABDUL OLABI
}

\begin{abstract}
Description and analysis of membrane electrode assembly and different manufacturing processes of Proton Electron Membrane has been made. Efforts were made to explain the types of assembly and manufacturing methods. Finding innovative ways to fabricate PEM fuel cell components, which affords mass production at lower operating cost, is one of the major threats to its commercialisation. Additive manufacturing techniques are seen as efficient and fast manufacturing methods that builds up components layer-by-layer in three dimensions, rather than conventional subtractive manufacturing techniques. This helps to reducing the overall cost, manufacturing time and wastage. The major aim of this work is to help people working with PEM fuel cells make informed decision regarding the selection of material and the choice of process. Choosing the right type of assembly and manufacturing method can go a long way to reduce the cost of production and durability.
\end{abstract}

Keywords: •MEA $\bullet$ manufacturing $\bullet$ PEM fuel cell $\bullet$ fabrication $\bullet$ solar energy $\bullet$.

CORRESPONDENCE ADDRESS: Abdulrahman Alanazi, University of the West of Scotland, Institute of Engineering and Energy Technologies, High St, Paisley PA1 2BE United Kingdom, e-mail: abdulrahman.elanazi@gmail.com. Emmanuel Ogungbemi, University of the West of Scotland, Institute of Engineering and Energy Technologies, High St, Paisley PA1 2BE United Kingdom, email: emmanuel.ogungbemi@uws.ac.uk. Awortwe Wilberforce, University of the West of Scotland, Institute of Engineering and Energy Technologies, High St, Paisley PA1 2BE United Kingdom, e-mail: awortwe.wiusereorce@uws.ac.uk. Oluwatosin S. Ijaodola, University of the West of Scotland, Institute of Engineering and Energy Technologies, High St, Paisley PA1 2BE United Kingdom, e-mail: oluwatosin.Ijadda@uws.ac.uk. Parag Vichare, University of the West of Scotland, Institute of Engineering and Energy Technologies, High St, Paisley PA1 2BE United Kingdom, e-mail: parag.vichare@uws.as.uk. Abdul-Ghani Olabi, University of the West of Scotland, Institute of Engineering and Energy Technologies, High St, Paisley PA1 2BE United Kingdom, e-mail: abdul.olabi@uws.as.uk. 
$190 \quad 10^{\mathrm{TH}}$ InTERnational CONFERENCE ON Sustainable ENERGy AND ENVIRONMENTAL Protection (June $27^{\mathrm{TH}}-30^{\mathrm{TH}}, 2017$, Bled, Slovenia), Hydrogen and Fuel Cells

A. Alanazi, E. Ogungbemi, A. Wilberforce, O. Ijaodola, P. Vichare \& A. Olabi: Stateof-the-Art Manufacturing Technologies of PEMFC Components

\section{Introduction}

Considering the current challenges facing the environment and meeting the required energy target, PEM fuel cells, being a sustainable energy [1,2] are realistic solutions. With events all around the world it is established that the need for fuel cells as an alternative energy is at the peak. This is because continued reliance on fossil fuel will only make the world a difficult place to live in due to high level of pollution [3-7]. Fuel cells, when converting fuels into energy, performs at efficiencies greater than the conventional combustion technologies [8]. They have been tested in some areas and have performed. These areas include transportation, powering stationary equipment and in the production of some small devices like cell phones, laptops, video recorders etc. Presently they have been used in the production of automobiles such as cars and buses; they have also been used in making stationary equipment like a power plant and a lot of portable applications. They have been used in combination with other clean energy sources, an example is solar energy[9].

Although the PEM fuel cell was invented by T. Grubb \& L. Niedrach at GE in the 1960s, many researches which led to this landmark achievement started in the 1800s. The first demonstration of fuel cell was carried out by Sir William Grove in 1836. Presently there are various types of researches on different types of fuels cells with approximately $90 \%$ of them focusing on PEM fuel cells. Therefore over the years a lot of success has been recorded towards the development of PEM fuel cells.

Fuel cell can be defined as a device that converts chemical energy into electrical energy in a controlled reaction where temperature is kept constant. The fuel cell has often been compared with a battery, the different being that while the reactants and electrolyte in a battery is sealed into the battery the fuel cell is supplied with fresh reactants. These reactants were being referred to as fuels. Examples of fuels used by fuel cells are hydrogen, oxygen, methanol, gasoline etc. For PEM (Proton Electrolyte Membrane), the reactants are hydrogen and oxygen.

Most researches on fuel cells now focus on Proton-electrolyte-membrane fuel cells (PEMFC). And in majority of this work, issues about adopting the technology have mostly been dominated by its effects on the environment and cost[10]. The PEM fuel cell, with water as its bye-product, has very low pollution emission. It is believed that continuous researches on materials and component will deliver the development of a more efficient system with a reduced cost. Work done on membrane electrode assembly and manufacturing can have a great effect on cost, performance and the shell life of the fuel cell. Figure 1 below shows the diagram of a PEM fuel cell and figure 2 shows a 
planar diagram of a PEM fuel cell. Detailed analysis of the entire different component that made up the fuel cell in figure 1 is analysed in figure 2.

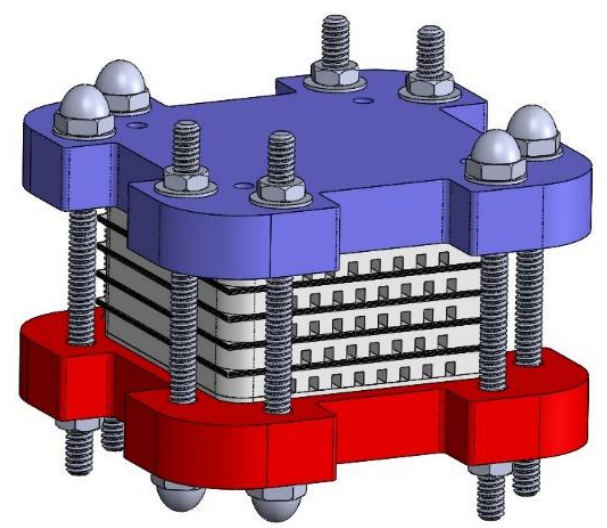

Figure 1: Diagram of a pem fuel cell

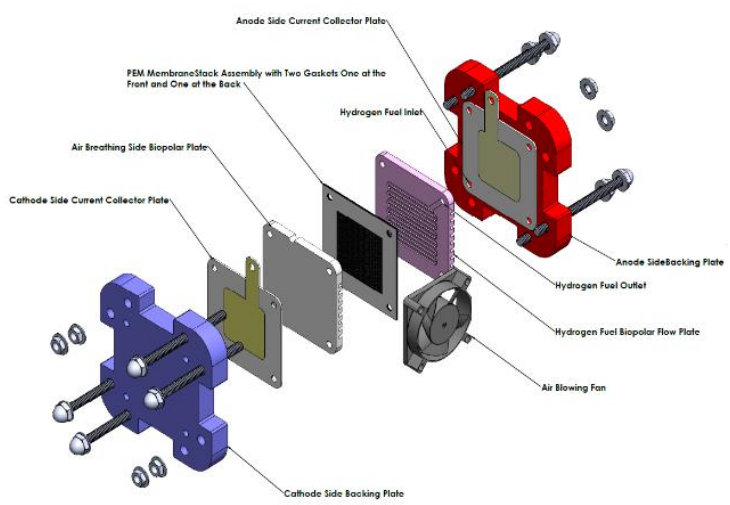

Figure 2: Planar diagram of a PEM fuel cell

\section{$2 \quad$ Membrane Electrode Assembly}

\subsection{Types of assembly}

Fundamentally there are two fabrication methods to assemble the MEA for PEMFC and are distinguished on the basis on where the catalyst ink is deposited to make the electrode. The first method is by deposition of the catalyst layer on a porous GDL such as carbon paper, followed by hot pressing it with the membrane to make the membrane. This method is commonly known as catalyst-coated substrate (CCS). In the second method, 
$19210^{\mathrm{TH}}$ InTERnational CONFERENCE ON Sustainable ENERGY AND ENVIRONMENTAL Protection (June $27^{\mathrm{TH}}-30^{\mathrm{TH}}, 2017$, Bled, Slovenia), Hydrogen ANd Fuel Cells

A. Alanazi, E. Ogungbemi, A. Wilberforce, O. Ijaodola, P. Vichare \& A. Olabi: Stateof-the-Art Manufacturing Technologies of PEMFC Components

the catalyst layer is deposited directly onto the membrane; this method is referred to as catalyst-coated membrane (CCM). Figure 3 illustrates the two methods.

In additional to the second method, an intermediate step has been introduced to overcome issues of membrane swelling and wrinkling due to the direct contact with catalyst ink throughout the fabrication process.

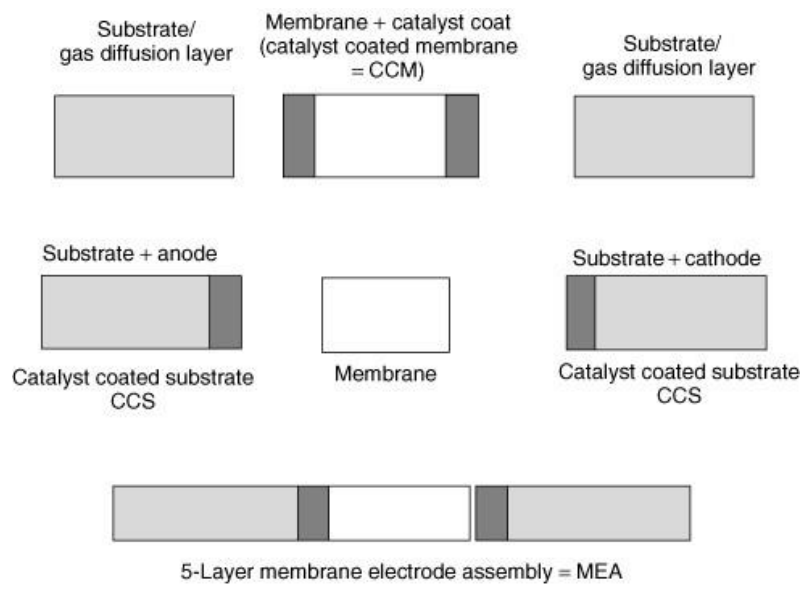

Figure 2: MEA's CCM and CCS fabrication methods

This step is known as Decal Method Transfer (DMT) and it involves the lamination of the catalyst layer onto the membrane through a temporary substrate such as Teflon film by pressing at a high temperature $210-250^{\circ} \mathrm{C}$ [11]. Thanaslip [12] investigated the performance of PEMFC at the three fabrication methods and reported that DMT type provided the highest cell performance, followed by MEA's made by CCM, and the lowest performance MEA's made by CCS. This is due to the fact that some of the Nanostructured catalyst particles protrude in GDL pores, leading to the reduction of their catalytic activation.

\subsection{Membrane processing}

The polymer electrolyte membrane is usually procured in roll form as an end product from its manufacturer, and the only processing steps required on it is to boil it in hydrogen peroxide, dilute sulphuric acid and water. These steps serve to clean the membrane, and to ensure that it is protonated [13].

\subsection{Diffusion layer processing}

The gas diffusion layer is composed of two layers, the Macro-porous layer and the Microporous layer. The Macro-porous layer is fundamentally the section where the diffusion media has been treated with a hydrophobic agent (PTFE). Hydrophobicity is a crucial 
$10^{\mathrm{TH}}$ INTERNATIONAL CONFERENCE ON SUSTAINABLE ENERGY AND ENVIRONMENTAL Protection (June $27^{\mathrm{TH}}-30^{\mathrm{TH}}, 2017$, Bled, Slovenia), ENERGy Storage

A. Alanazi, E. Ogungbemi, A. Wilberforce, O. Ijaodola, P. Vichare \& A. Olabi: State-of-the-Art Manufacturing Technologies of PEMFC Components

requirement to avoid flooding of water in the diffusion media channels. The precursor for the diffusion media is generally either carbon cloth or carbon paper, and the macro-porous layer is formed by applying Teflon solution onto the substrate. The microporous layer which helps in managing the water content of the MEA [14], is a far thinner layer made by coating the macro-porous layer that is mixed with carbon black and PTFE. Content of PTFE in both layers is also important, as it directly change the porosity and hydrophobicity of the diffusion media which in turn affects the reactants mass transport to the catalyst layers [15]. The method in which this mixture is deposited is similar to how the electrode layers are formed, thus the same processes can be used to fabricate the micro-porous layer.

\subsection{Catalyst ink preparation}

The catalyst ink, a liquid precursor of the catalyst layer, is usually composed of the following components as reported by Wilson [6]:

- Catalyst (platinum, platinum supported)

- Electrolyte/inomer (PFSA or other protonated inomers)

- Solvent (deionised water, glycerol)

- Additive (dispersing agents)

Wilson [16] stated that the first consideration when preparing the ink is the composition of each component, followed by the compound's viscosity and the surface tension.

\section{State-of-the-Art Manufacturing Methods}

One of the challenges of the commercialisation of PEMFC is finding new and innovative ways to fabricate the different components that will enable mass production at reduced operating costs [17]. Additive manufacturing (AM), better known as 3D printing is perceived as a way to develop cost effective PEMFC. The following graph illustrates some the AM technologies based on the form of the starting material.
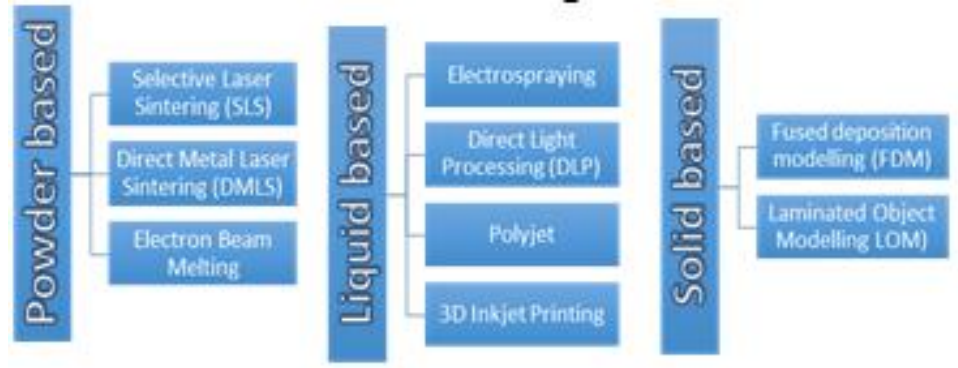

Figure 3: AM manufacturing technologies 
$19410^{\mathrm{TH}}$ InTERnAtional CONFERENCE ON Sustainable ENERGy AND ENVIRONMENTAL Protection (June $27^{\mathrm{TH}}-30^{\mathrm{TH}}, 2017$, Bled, Slovenia), Hydrogen and Fuel Cells

A. Alanazi, E. Ogungbemi, A. Wilberforce, O. Ijaodola, P. Vichare \& A. Olabi: Stateof-the-Art Manufacturing Technologies of PEMFC Components

\subsection{D inkjet printing}

Recently there has been a lot of interest with respect to the inkjet printing technology for manufacturing the catalyst layers onto the MEA's. Towne et al. [18] investigated the possibility of manufacturing the GDE (Gas Diffusion Electrode) for PEMFC MEA using off the shelf inkjet printing equipment. Although they have successfully shown the high capabilities of the process, there were few concerns with the process. The drop size, jetting velocity, print head speed, number of nozzles, distance between nozzles, and platen speed cannot be manually controlled. Furthermore, the nozzles of the print heads are in the range 10-20 $\mu \mathrm{m}$ which are very small in size. This causes to coagulation of droplets in the print heads. Thus, to avoid these problems, the catalyst powder has to be ground fine using high cost equipment such as ball mills etc. The catalyst powder size must be around 100-500 nm for the ink droplets to not coagulate in the print heads. This in turn results in an increase in the cost of the catalyst powders.

When comparing this process with conventional processes such as hand painting method. The former process has demonstrated a better quality control, and less assembly time, which was 30 seconds against 5 minutes.

\subsection{Fused deposition modelling}

Fused Deposition Modelling is an additive fabrication technology which constructs superior rapid prototypes from $3 \mathrm{D}$ CAD data where in a thermo plastic material is extruded in the form of beads layer by layer using a temperature controlled head which is controlled by Computer Aided Manufacturing (CAM) software [19]. The thermo plastic materials used in FDM process have good stability and durability of the mechanical properties over time; they have high heat resistance and also produce smooth parts with all the finest details intact.

Chen [21] used this technology to manufacture miniature fuel stacks in a planner array form. For the fabrication of miniature fuel cell it is required to have pinpoint precision, as the aim of this type of fuel cell is to have high power density. Alternative conventional methods include Micro-Electro-Mechanical MEM processes and CNC machining process. Chen Have compared the two conventional processes with FDM in the fabrication of the flow field geometry and reported that more precision was achieved with FDM and it required less time which was 1 hour compared to 2 hours and 20 hours for CNC and MEM's respectively 


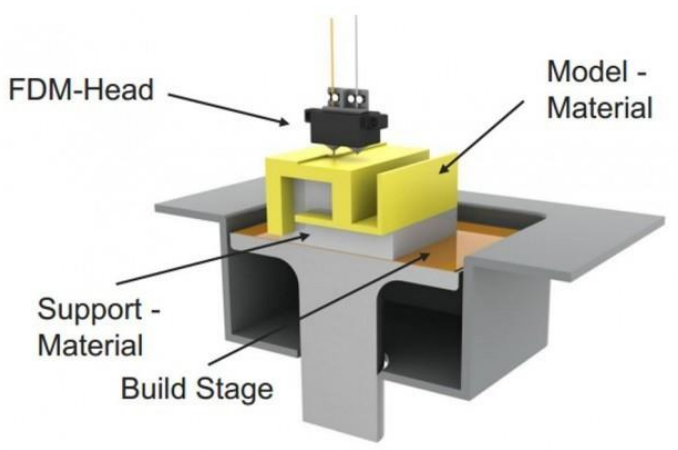

Figure 4: FDM process [20]

\subsection{Selective laser sintering}

The objects in Laser Sintering (SLS) manufacturing process are made by printing powder materials, most commonly plastics such as polyamide, polyethylene etc. The laser's energy is directed to the bed surface and thus used to build up a 3D structure in a layerwise routine, layer by layer. This process is particularly suited for bipolar plate component as $316 \mathrm{~L}$ and other stainless steels are frequently used to produce net shape products that are 98 to $99 \%$ dense. The process needs to generate a 3D CAD model of the object to be printed and then converted into the compatible file format for uploading to the SLS machine. The process offers several advantages for the development of bipolar plates in comparison to conventional method Compression Molding (CM). It offers the ability to build complex flow fields and consumes less time and financial resources. A number of authors [22] have investigated the fabrication of graphite composite bipolar plate using this technology. Components made from SLS have proven to have lower electrical conductivity, and more porous. It's therefore required to post process the components to improve conductivity and obtain gas impermeability which are essential requirements for bipolar plates materials. One of the treatments that can be used to improve conductivity of bipolar plates is liquid phenolic infiltration, which was shown by Chen and the treatment was able to boost conductivity by 35\% [23]. Another disadvantage of the process is the roughness of the surface finish produced, which is highly dependant on the size of powder particles. This can be enhanced by a surface remelting process as shown by Yesa [24].

\subsection{Direct metal laser sintering (DMLS)}

This process works in the same manner as SLS in terms of using a laser as a way to consolidate powder, except for using a metal powder as source of material. With DMLS, the metal powder, and the fluxing agent, is fully melted by the scanning of a focused laser is completed, a blade adds a new layer and repeats the process until the last metal part is formed as illustrated in figure 6 . 
$19610^{\mathrm{TH}}$ InTERnATIONAL CONFERENCE ON Sustainable ENERGy AND ENVIRONMENTAL Protection (June $27^{\mathrm{TH}}-30^{\mathrm{TH}}, 2017$, Bled, Slovenia), Hydrogen ANd Fuel Cells

A. Alanazi, E. Ogungbemi, A. Wilberforce, O. Ijaodola, P. Vichare \& A. Olabi: Stateof-the-Art Manufacturing Technologies of PEMFC Components

Removing the polymer binder prevents the burn off and infiltration steps, and it provide a $95 \%$ dense steel component compared to roughly $70 \%$ density with SLS. Furthermore leftover powder can be used again, which thus decreases waste level. DMLS has different requirements for the design of parts, as well as special positioning requirements of the parts on the bed.

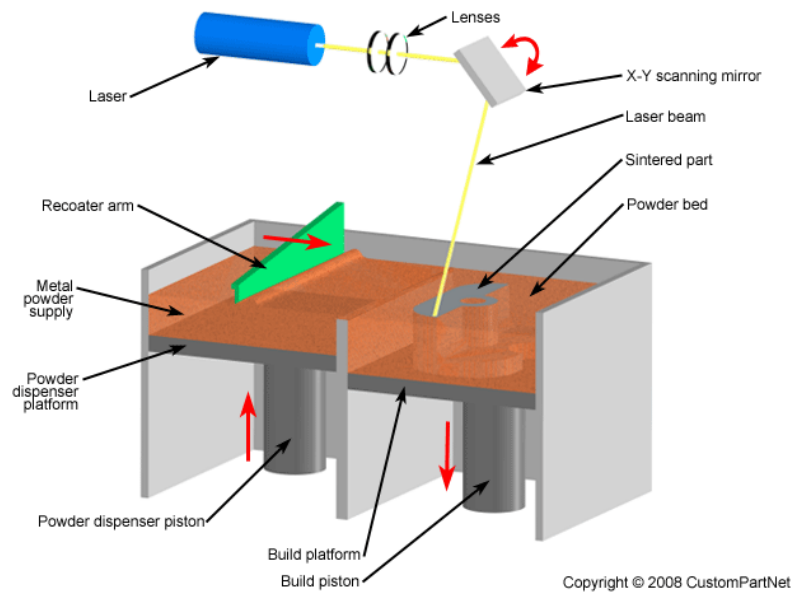

Figure 5: DMLS Process [25]

\section{$4 \quad$ Conclusion}

Attempt has been made to discuss membrane electrode assembly and the additive technologies used to manufacture PEM fuel cell components. The best manufacturing method to be used is determined based on the starting material. Also finding new and innovative ways to fabricate the different components could enable mass production at reduced operation cost.

\section{Acknowledgements}

The authors acknowledge everyone who has contributed to the success of this paper and research in general.

\section{References}

1. Olabi A. 100\% sustainable energy 2014. doi:10.1016/j.energy.2014.10.083.

2. Olabi A. State of the art on renewable and sustainable energy. Energy 2013;61:2-5. doi:10.1016/j.energy.2013.10.013.

3. Olabi A. Developments in sustainable energy and environmental protection 2012. doi:10.1016/j.energy.2011.12.037.

4. Olabi A. Hydrogen and Fuel Cell developments: An introduction to the special issue on "The 8th International Conference on Sustainable Energy and Environmental Protection 
$10^{\mathrm{TH}}$ INTERNATIONAL CONFERENCE ON SUSTAINABLE ENERGY AND ENVIRONMENTAL Protection (June $27^{\mathrm{TH}}-30^{\mathrm{TH}}, 2017$, Bled, Slovenia), ENERGy Storage

A. Alanazi, E. Ogungbemi, A. Wilberforce, O. Ijaodola, P. Vichare \& A. Olabi: State-of-the-Art Manufacturing Technologies of PEMFC Components

(SEEP 2015), 11-14 August 2015, Paisley, Scotland, UK'. Int J Hydrogen Energy 2016;41:16323-9. doi:10.1016/j.ijhydene.2016.07.235.

5. Cheng X, Shi Z, Glass N, Zhang L, Zhang J, Song D, et al. A review of PEM hydrogen fuel cell contamination: Impacts, mechanisms, and mitigation 2007;165:739-56. doi:10.1016/j.jpowsour.2006.12.012.

6. Wilberforce T, Alaswad A, Palumbo A, Dassisti M, Olabi AG. Advances in stationary and portable fuel cell applications 2016. doi:10.1016/j.ijhydene.2016.02.057.

7. Alaswad A, Baroutaji A, Achour H, Carton J, Makky A Al, Olabi AG. Developments in fuel cell technologies in the transport sector 2016. doi:10.1016/j.ijhydene.2016.03.164.

8. Brandon N, Hart D. An introduction to fuel cell technology and economics Policy and Technology 1999.

9. Wilson JF, Srinivasan SS, Moore BM, Henderson L, Iii SE, Sharma PC. Hydrogen Production Using Solar Energy 2013.

10. Sulaiman N, Hannan MA, Mohamed A, Majlan EH, Daud WRW. A review on energy management system for fuel cell hybrid electric vehicle: Issues and challenges. Renew Sustain Energy Rev 2015;52:802-14. doi:10.1016/j.rser.2015.07.132.

11. Development Of A Low Temperature Decal Transfer Method For The Fabrication Of Proton Exchange Membrane Fuel Cells". Sciencedirect.com. N.p., 2017. Web. 26 Apr. 2017.

12. Effect Of MEA Fabrication Techniques On The Cell Performance Of $\mathrm{Pt}-\mathrm{Pd} / \mathrm{C}$ Electrocatalyst For Oxygen Reduction In PEM Fuel Cell". Sciencedirect.com. N.p., 2017. Web. 26 Apr. 2017.

13. Xiaoming Ren, Piotr Zelenay, Sharon Thomas, John Davey, and Shimshon Gottesfeld. Recent advances in direct methanol fuel cells at los alamos national laboratory. Journal of Power Sources, 86(1-2):111 - 116, 2000.

14. E. Passalacqua, G. Squadrito, F. Lufrano, A. Patti, and L. Giorgi. Effects of the diffusion layer characteristics on the performance of polymer electrolyte fuel cell electrodes. Journal of Applied Electrochemistry, 31(4):449-454, 2001.

15. L. Giorgi, E. Antolini, A. Pozio, and E. Passalacqua. Influence of the ptfe content in the diffusion layer of low-pt loading electrodes for polymer electrolyte fuel cells. Electrochimica Acta, 43(24):3675-3680, 1998.

16. MS Wilson and S. Gottesfeld. Thin-film catalyst layers for polymer electrolyte fuel cell electrodes. Journal of Applied Electrochemistry, 22(1):1-7, 1992.

17. Y. Wang, K.S. Chen, J. Mishler, S.C. Cho, X.C. Adroher, Applied Energy, 88 (2011)

18. Silas Towne, Vish Viswanathan, James Holbery, Peter Rieke, Fabrication of polymer electrolyte membrane fuel cell MEAs utilizing inkjet print technology, Journal of Power Sources 171 (2007) 575-584,2007.

19. Weihong Zhong, Fan Li, Zuoguang Zhang, Lulu Song, Zhimin Li, Short fiber reinforced composites for fused deposition modeling, Materials Science and Engineering A301 (2001) $125-130$

20. PHIL LAMBERT (2014) SLS method \& FDM process for 3D printing with Plastic, Available at: https://www.sculpteo.com/blog/2014/05/13/right-plasticproduction-method/(Accessed: 25th April 2017).

21. Chen-Yu Chen, Wei-Hsiang Lai, Biing-Jyh Weng, Huey-Jan Chuang, Ching-Yuan Hsieh, Chien-Chih Kung, Planar array stack design aided by rapid prototyping in development of air-breathing PEMFC Journal of Power Sources 179 (2008) 147-154, 2007.

22. N. Guo, M.C. Leu, Effect of different graphite materials on the electrical conductivity and flextural strength of bipolar plates fabricated using selective laser sintering, Int. J.

Hydrogen Energy, 2012, 37: 3558-3566. 
198 10 $10^{\mathrm{TH}}$ InTERnational CONFERENCE ON Sustainable EnERgy and ENVIRONMENTAL Protection (June $27^{\mathrm{TH}}-30^{\mathrm{TH}}, 2017$, BLed, Slovenia), Hydrogen AND Fuel Cells

A. Alanazi, E. Ogungbemi, A. Wilberforce, O. Ijaodola, P. Vichare \& A. Olabi: Stateof-the-Art Manufacturing Technologies of PEMFC Components

23. S. Chen, D.L. Bourell, K.L.Wood, Improvement of electrical conductivity of SLS PEM fuel cell bipolar plates. Proceedings of the International SFF Symposium, 2005:458-467.

24. Yasa E, Kruth JP, Deckers J (2011) Manufacturing by combining Selective Laser Melting and Selective Laser Erosion/laser re-melting. CIRP Ann-manuf techn 60 (1):263-266.

25. Custompart (2017) Direct Metal Laser Sintering, Available at: http://www.custompartnet.com/wu/direct-metal-laser-sintering (Accessed: 26th April 2017). 
$10^{\mathrm{TH}}$ INTERNATIONAL CONFERENCE ON Sustainable ENERgy AND ENVIRONMENTAL Protection (June $27^{\mathrm{TH}}-30^{\mathrm{TH}}$, 2017, Bled, Slovenia), Hydrogen ANd Fuel Cells

J. Krope, A.Ghani Olabi, D. Goričanec \& S. Božičnik

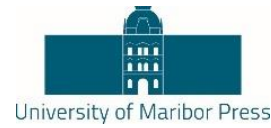

\title{
Turbulent Burning Velocity of Mixture of Methane and a High Hydrogen Content Syngas
}

\author{
Arley Cardona Vargas, Alex M. García, Fabián E. Cano Ardila, Carlos E. \\ Arrieta, Hernando A. YePES \& ANDrÉS A. AMELL
}

\begin{abstract}
This paper aims to present the experimental study of turbulent burning velocity in premixed syngas/CH4/air lean-flames stabilized with a nozzle-type Bunsen. The syngas evaluated, is a high hydrogen content syngas, which is typical of Conoco-Phillips coal gasification processes. Measurements were performed at 849 mbar (absolute) and $297 \pm 1 \mathrm{~K}$. To measure the turbulent burning velocity, we applied the angle method with Schlieren visualization. Perforated plates were used to produce different turbulence levels, which were measured with a hot-wire anemometer CTA (Constant temperature anemometer). Additionally, the numerical laminar burning velocity of methane and the syngas/CH4/air mixture were estimated. The interaction between turbulence and flame was analyzed based on the geometric parameters combined with laminar flame properties and turbulence length scales. Results show that the turbulent burning velocity and the ratio between turbulent and laminar burning velocities, S_TS_L, increases with turbulence intensity $\mathrm{u}^{\wedge}$. The addition of syngas generally resulted in increased turbulent and laminar burning velocity.
\end{abstract}

Keywords: - Turbulent burning velocity - Hot-wire anemometer • Schlieren $\bullet$ Syngas $\bullet$ Hydrogen $\bullet$.

CORRESPONDENCE AdDRESS: Arley Cardona Vargas, Mechanical Engineer, M.Sc. student, Universidad de Antioquia, Facultad de Ingeniería, Grupo de Ciencia y Tecnología del Gas y Uso Racional de la Energía, Cl. 67 \#53 - 108, Medellín, Colombia, e-mail: johany.cardona@udea.edu.co. Alex M. García, Mechanical Engineer, M.Sc. student, Universidad de Antioquia, Facultad de Ingeniería, Grupo de Ciencia y Tecnología del Gas y Uso Racional de la Energía, Cl. 67 \#53 - 108, Medellín, Colombia, e-mail: alex.garciav@udea.edu.co. Fabián E. Cano Ardila, Mechanical Engineer, M.Sc. student, Universidad de Antioquia, Facultad de Ingeniería, Grupo de Ciencia y Tecnología del Gas y Uso Racional de la Energía, Cl. 67 \#53 - 108, Medellín, Colombia, e-mail: fabian.cano@udea.edu.co. Carlos E. Arrieta, M.Sc., Ph.D student, Universidad de Antioquia, Facultad de Ingeniería, Grupo de Ciencia y Tecnología del Gas y Uso Racional de la Energía, Cl. 67 \#53 - 108, Medellín, Colombia, e-mail: ernesto.arrieta@udea.edu.co. Hernando A. Yepes, Mechanical Engineer, M.Sc., Universidad de Antioquia, Facultad de Ingeniería, Grupo de Ciencia y Tecnología del Gas y Uso Racional de la Energía, Cl. 67 \#53 - 108, Medellín, Colombia, e-mail: hernando.yepes@udea.edu.co., Andrés A. Amell, M.Sc., Professor, Universidad de Antioquia, Facultad de Ingeniería, Grupo de Ciencia y Tecnología del Gas y Uso Racional de la Energía, Cl. 67 \#53 - 108, Medellín, Colombia, e-mail: andres.amell@udea.edu.co.

https://doi.org/10.18690/978-961-286-054-7.18

ISBN 978-961-286-054-7

(C) 2017 University of Maribor Press

Available at: http://press.um.si. 
$10^{\mathrm{TH}}$ International Conference on Sustainable Energy and Environmental Protection (June $27^{\mathrm{TH}}-30^{\mathrm{TH}}, 2017$, Bled, Slovenia), Hydrogen and Fuel Cells

A. Cardona Vargas, A. M. García, F. E. Cano Ardila, C. E. Arrieta, H. A. Yepes \& A. A. Amell: Turbulent Burning Velocity of Mixture of Methane and a High Hydrogen Content Syngas

\section{$1 \quad$ Introduction}

The vast majority of industrial combustion devices operate under turbulent conditions [13]. Therefore, the comprehension of the associated phenomena and quantification of basic parameters to model the combustion process under turbulent flow conditions are a critical factor in the development of more efficient energy equipment and the implementation of alternative fuels $[4,5]$.

In this sense, the turbulent burning velocity, $\mathrm{S}_{\mathrm{T}}$, is one of the fundamental parameters to characterize and compare turbulent premixed flames $[4,6]$. In the literature, there exist a great amount of works focused in the measurement of this parameter by mean of different techniques[7-11]. However, most of these investigations were carried out using fossil fuels in atmospheric conditions; only in the recent years, alternative gas fuels such as synthesis gas, have begun to be studied [12,13].

Synthesis gas, or syngas, is a fuel gas mixture consisting mainly of $\mathrm{H}_{2}, \mathrm{CO}$ and some inerts and hydrocarbons [5]. The relevance of this alternative fuel has been discussed in many studies [5, 14-16], which indicate that the implementation of syngas leads to: diversifying the energy supply, improve the combustion characteristics as the laminar and turbulent burning velocity and extends the flammability limit in lean conditions. Moreover, carbon dioxide and other pollutant emissions are considerably reduced compared to conventional fuels, due to the presence of hydrogen in the syngas mixture and the use of clean up methods after the gasification process.

Additionally to the facts mentioned above, the combustion of hydrogen, which is a component of syngas, has unique characteristics such as the high reactivity, diffusivity, and the high concentration of free radicals such as $\mathrm{O}, \mathrm{H}$ and $\mathrm{OH}$ in its flames. Hydrogen combustion possesses fast laminar burning velocity and very thin flame thickness, and it may cause undesired flame instability and hydrodynamic instability. Compared with traditional hydrocarbon fuels, the hydrogen content in the syngas will induce different turbulence-flame interaction in turbulent premixed flames [5].

On the other hand, the effect of operating conditions such as temperature and pressure on $\mathrm{S}_{\mathrm{T}}$ have had a special interest in combustion studies, especially to optimize and extend the operation of this types of flames and avoid blowout, extinction, and flashback.

The effect of pressure on $\mathrm{S}_{\mathrm{T}}$ has been widely studied for values higher than atmospheric. $[10,17]$. Nevertheless, the behaviour of $S_{\mathrm{T}}$ at sub-atmospheric pressures have been poorly studied and according to the review made by the authors, the availability of data is null. Moreover, taking into account that several principal cities of developing countries are located at above sea level it is important to obtain data of $S_{T}$ at sub-atmospheric conditions. 
$10^{\mathrm{TH}}$ INTERNATIONAL CONFERENCE ON SUSTAINABLE ENERGY AND ENVIRONMENTAL Protection (June $27^{\mathrm{TH}}-30^{\mathrm{TH}}, 2017$, Bled, SLovenia), EnERgy Storage

A. Cardona Vargas, A. M. García, F. E. Cano Ardila, C. E. Arrieta, H. A. Yepes \& A. A. Amell: Turbulent Burning Velocity of Mixture of Methane and a High Hydrogen Content Syngas

In this study, turbulent burning velocities of syngas/ $\mathrm{CH}_{4} /$ air flames were determined experimentally by the angle method. The mean flame cone was determined using Schlieren technique, whereas laminar burning velocities were obtained numerically within equivalence ratios range (0.8-1.0). Also, we evaluated the effect of syngas addition on the turbulent and laminar burning velocity of syngas/ $\mathrm{CH}_{4} /$ air mixtures at subatmospheric pressure.

\section{$2 \quad$ Methodology}

\subsection{Experimental setup}

A controllable turbulent flame was generated by a nozzle-type turbulent premixed Bunsen burner with an outlet diameter of $10 \mathrm{~mm}$ as shown in Figure 1. Turbulence is generated by a perforated plate installed $42 \mathrm{~mm}$ upstream of the nozzle outlet. Three kinds of plates were used to generate different turbulence conditions. The plates have 12 orifices with a diameter and blockage of $2 \mathrm{~mm}, 2.4 \mathrm{~mm}, 2.8 \mathrm{~mm}$, and 88\%, 83\%, 77\%, respectively. A hydrogen diffusion pilot flame slit with a thickness of $0.5 \mathrm{~mm}$ around the nozzle outlet was served to stabilize the turbulent flame. Additionally, a cooling water circuit inside the burner keeps the mixtures at a constant temperature.

Turbulence parameters at nozzle outlet were measured using a constant-temperature hotwire anemometer (miniCTA 54T42 Dantec Dynamics) at the center of the burner outlet. The single 1D-55P11 probe was used. Turbulent flow parameters were calculated by assuming Taylor hypothesis and isotropic turbulence assumption. For each condition, mixture, equivalence ratio and turbulent intensity, 2400000 data were registered at a frequency of $40 \mathrm{KHz}$. The mean velocity and their root mean square, u', were calculated from the recorded data.

Several lean syngas/ $/ \mathrm{CH}_{4} /$ air flames were generated in the burner described above. The air was supplied by an air compressor and dried using two inline water traps. Each air-tofuel ratio and exit velocity were ensured using rotameters that were specifically calibrated for each component gas, similar to those used in $[16,18]$. The errors in the final composition were estimated to be lower than $2 \%$. 
$10^{\text {Th }}$ International Conference on Sustainable Energy and Environmental Protection (June $27^{\mathrm{TH}}-30^{\mathrm{TH}}, 2017$, Bled, Slovenia), Hydrogen ANd Fuel Cells

A. Cardona Vargas, A. M. García, F. E. Cano Ardila, C. E. Arrieta, H. A. Yepes \& A. A. Amell: Turbulent Burning Velocity of Mixture of Methane and a High Hydrogen Content Syngas

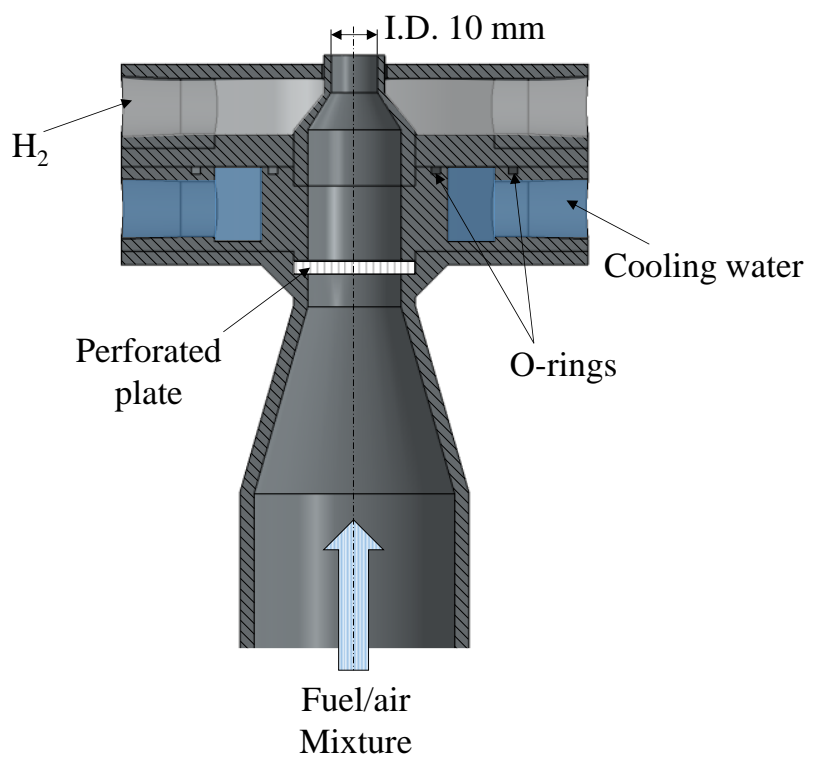

Figure 1. Schematic of the Bunsen burner.

In the present study, we evaluated the effect of syngas addition on the laminar and turbulent burning velocity of syngas/ $\mathrm{CH}_{4} /$ air mixture, equivalence ratios between 0.8 and 1.0. The addition of syngas to the methane was $30 \%$ in volume; the compositions of the fuels are shown in the Table 2. The measurements were carried out at $297 \mathrm{~K}$ and 849 mbar of atmospheric pressure. The experiments were conducted using a CCD camera (Basler scA1400-30 gm, 1392 x 1040 pixels, $30 \mathrm{fps}$ ) and Schlieren technique were performed to visualize the instantaneous flame front, values of $S_{T}$ were determined with the angle method [19] and were compared with other authors.

Table 2. Volumetric composition of syngas and syngas $/ \mathrm{CH}_{4}$ mixture used in the study.

\begin{tabular}{|c|c|}
\hline Fuel & Fuel composition \\
\hline Syngas & $40 \% \mathrm{H}_{2}+40 \% \mathrm{CO}+20 \% \mathrm{CO}_{2}$ \\
\hline Mixture & $70 \% \mathrm{CH}_{4}+12 \% \mathrm{H}_{2}+12 \% \mathrm{CO}+6 \% \mathrm{CO}_{2}$ \\
\hline
\end{tabular}

\subsection{Image processing}

The images obtained were processed in order to determine the mean flame cone. The steps of the image processing can be seen in Figure 2. The image processing for each condition measurement consists in to define the contour of the flame in each Schlieren image captured. We obtained 60 images in each measurement. 
A. Cardona Vargas, A. M. García, F. E. Cano Ardila, C. E. Arrieta, H. A. Yepes \& A. A. Amell: Turbulent Burning Velocity of Mixture of Methane and a High Hydrogen Content Syngas

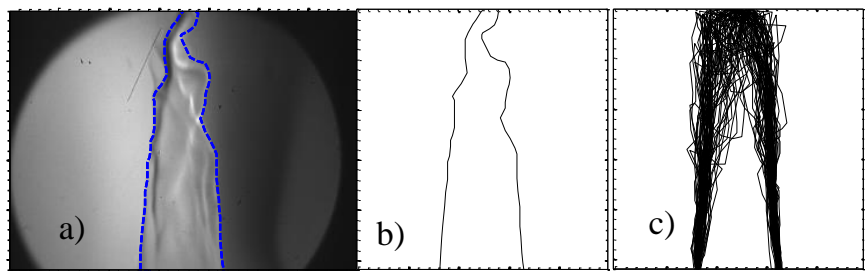

Figure 2. Image processing. a) Schlieren image b) Instantaneous flame front. c) Overlap of 60 flame fronts.

Once 60 flame fronts are obtained, the progress variable $c(x, y)$ is used to determine the mean flame cone according to the methodology described by Kobayashi et al [4] and Wang et al [20]. The progress variable is 0 in the unburned side of the flame and takes a value of 1 when the reactive mixture is totally burned. The change from 0 to 1 can be considered to occur immediately in the flame front, according with Kobayashi et al [4].

The progress variable was determined for the 60 images, obtaining the mean progress variable $\langle c\rangle$. A contour of this is shown in Figure 3a. Following the work done by [4] and [20], $\mathrm{S}_{\mathrm{T}}$ was defined as a function of the mean flame cone using $\langle c\rangle=0.1$ with a tolerance of 0.01 as described in Figure $3 \mathrm{~b}$.

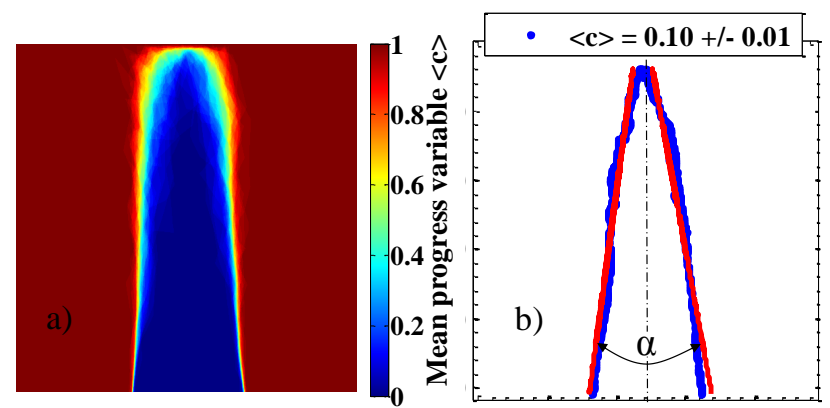

Figure 3. a). Contour of mean progress variable. b). Mean flame cone profile at $\langle c\rangle$ $=0.1$.

The value of $S_{\mathrm{T}}$ is calculated with the Equation (1), using the mean velocity and the flame angle calculated as described above.

$\mathrm{S}_{\mathrm{T}}=\mathrm{U} \sin \left(\frac{\alpha}{2}\right)$

Where $\mathrm{U}$ is the mean velocity of the flow, and $\alpha$ is the flame angle. 
$10^{\text {TH }}$ International Conference on Sustainable Energy and Environmental Protection (June $27^{\mathrm{TH}}-30^{\mathrm{TH}}, 2017$, Bled, Slovenia), Hydrogen and Fuel Cells

A. Cardona Vargas, A. M. García, F. E. Cano Ardila, C. E. Arrieta, H. A. Yepes \& A. A. Amell: Turbulent Burning Velocity of Mixture of Methane and a High Hydrogen Content Syngas

\subsection{Laminar burning velocity}

The laminar burning velocities, $S_{\mathrm{L}}$, which are needed for the study, were calculated for the methane and the mixture by mean of CHEMKIN-PRO software, in particular, the subroutines PREMIX and EQUIL were used, according to the methodology described in previous work $[18,21]$. The detailed mechanism selected for the calculations was the USC II [22] due to the accurate shown to predict $S_{\mathrm{L}}$ for the methane and different syngas mixtures [23].

\section{$3 \quad$ Results}

Figure 4 shows the numerical laminar burning velocity for $\mathrm{CH}_{4} /$ air and syngas/ $\mathrm{CH}_{4} /$ air mixtures. As can be seen, the values of $\mathrm{S}_{\mathrm{L}}$ for the syngas/ $\mathrm{CH}_{4} /$ air mixture are higher for all equivalence ratios considered. This behavior is generated by the content of hydrogen in the syngas. Its high reactivity accelerates the reaction process and therefore $S_{L}$ increases.

Additionally, experimental data of the laminar burning velocities for methane and syngas were included to compare it with the numerical results obtained in the present work. The data were obtained by Cardona et al [23] and Burbano et al [21] respectively. The prediction shows a good agreement between numerical and experimental results for $\mathrm{CH}_{4} /$ air mixture, and syngas/air mixtures.

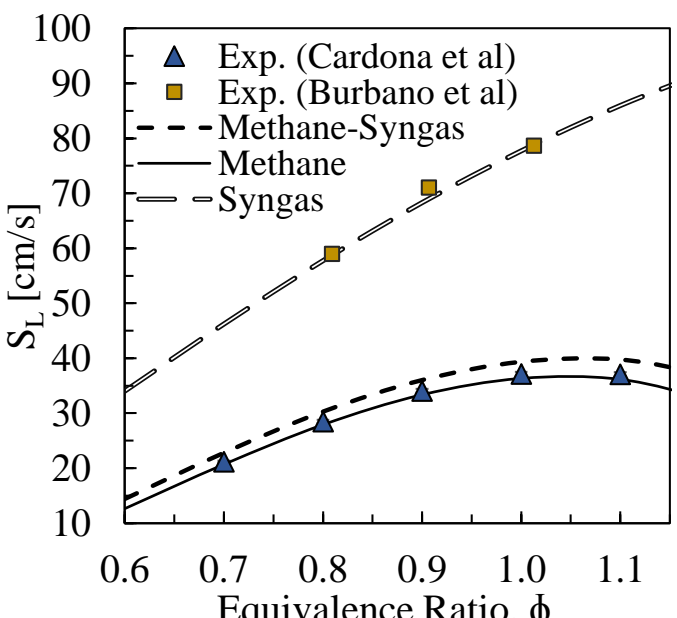

Figure 4. Laminar burning velocities of $\mathrm{CH}_{4} /$ air mixture and syngas/ $\mathrm{CH}_{4} /$ air mixture. At 849 mbar, $297 \mathrm{~K}$.

It is well known that the characteristics of turbulent premixed flames quite depend on the regimes, and the regimes are defined by laminar flame thickness, Kolmogorov 
A. Cardona Vargas, A. M. García, F. E. Cano Ardila, C. E. Arrieta, H. A. Yepes \& A. A.

Amell: Turbulent Burning Velocity of Mixture of Methane and a High Hydrogen

Content Syngas

microscale, and integral scale. The laminar flame thickness was calculated by $\delta_{\mathrm{L}}=$ $\mathrm{D}_{\text {th }} / \mathrm{S}_{\mathrm{L}}$, where, $\mathrm{D}_{\text {th }}$ is the thermal diffusivity of the unburned mixtures, and $\mathrm{S}_{\mathrm{L}}$ is the laminar burning velocity of the mixtures. Figure 5 shows the turbulent premixed flames of the present work located in the Borghi's diagram modified by Peters [24]. It can be seen that all the flames of the present work are located in the flamelet regime.

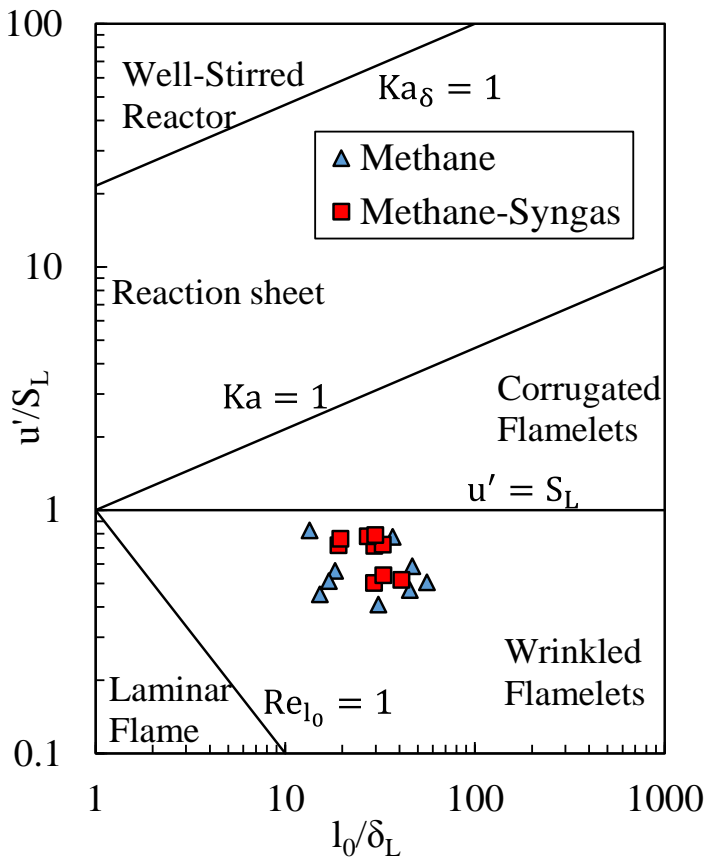

Figure 5. Borghi's diagram of turbulent premixed flames.

Figure 6 shows a rate between turbulent burning velocity and laminar burning velocity, and rate of turbulence intensity and laminar burning velocity and are compared with those of previous studies for methane by Kobayashi et al [17] and Zhang et al [25]. The increase of turbulent burning velocity in the syngas/ $\mathrm{CH}_{4} /$ air mixture respect to the $\mathrm{CH}_{4} /$ air mixture is related to the content of hydrogen in the syngas. 
206 10 $10^{\text {TH }}$ InTERnational CONFERENCE ON Sustainable ENERGy AND ENVIRONMENTAL Protection (June $27^{\mathrm{TH}}-30^{\mathrm{TH}}, 2017$, Bled, Slovenia), Hydrogen and Fuel Cells

A. Cardona Vargas, A. M. García, F. E. Cano Ardila, C. E. Arrieta, H. A. Yepes \& A. A. Amell: Turbulent Burning Velocity of Mixture of Methane and a High Hydrogen Content Syngas

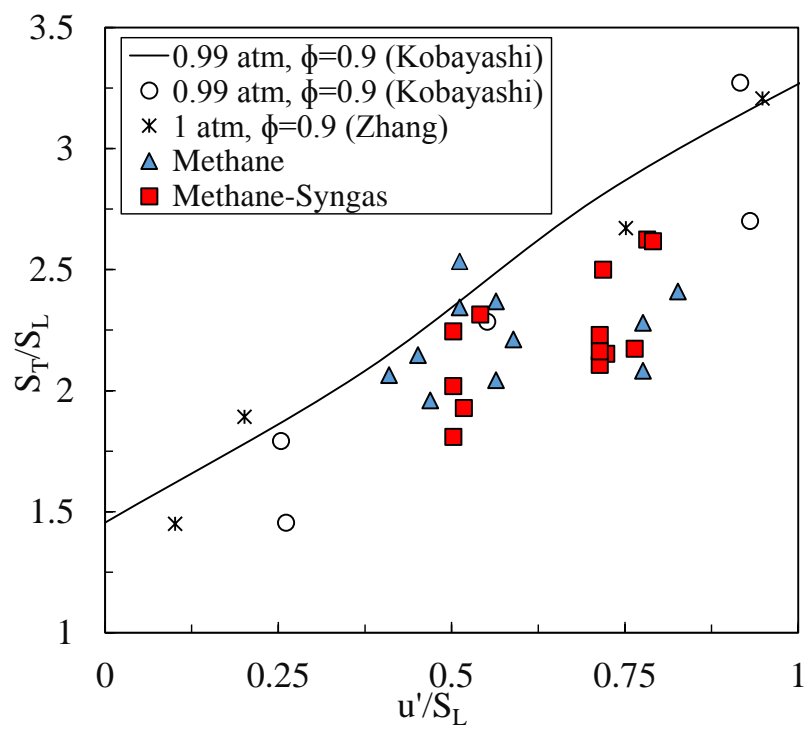

Figure 6. Turbulent burning velocity and comparison with previous studies.

$\mathrm{S}_{\mathrm{T}}$ versus equivalence ratio is shown in Figure 7 for the $\mathrm{CH}_{4} /$ air and syngas $/ \mathrm{CH}_{4} /$ air mixtures studied. It is evidenced that with the increase of equivalence ratio $S_{T}$ is increased. Besides, it was found that for a blockage of $88 \%$, the addition of syngas increases turbulent burning velocity in $10.3 \%, 3.3 \%$, and $4 \%$ for $0.8,0.9$ and 1.0 of equivalence ratios, respectively.

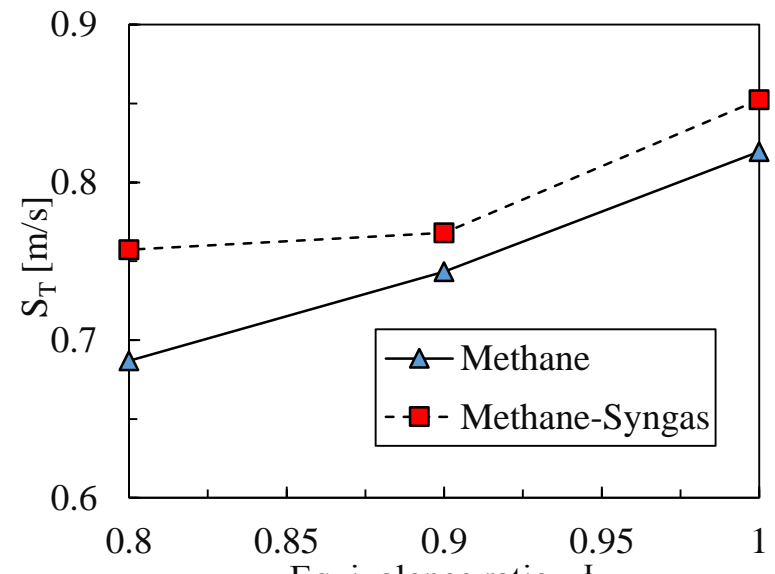

Equivalence ratio, $\phi$

Figure 7. Turbulent burning velocity vs equivalence ratio for $\mathrm{CH}_{4} /$ air and syngas/ $\mathrm{CH}_{4} /$ air mixtures for a blockage of $88 \%$. 
$10^{\mathrm{TH}}$ INTERNATIONAL CONFERENCE ON SUSTAINABLE ENERGY AND ENVIRONMENTAL Protection (June $27^{\mathrm{TH}}-30^{\mathrm{TH}}, 2017$, Bled, SLovenia), EnERgy Storage

A. Cardona Vargas, A. M. García, F. E. Cano Ardila, C. E. Arrieta, H. A. Yepes \& A. A.

Amell: Turbulent Burning Velocity of Mixture of Methane and a High Hydrogen

Content Syngas

\section{$4 \quad$ Conclusions}

Turbulent burning velocities of $\mathrm{CH}_{4} /$ air and syngas/ $/ \mathrm{CH}_{4} /$ air mixtures were measured burning lean-flames stabilized with a nozzle-type Bunsen at sub-atmospheric conditions. Additionally $\mathrm{u}^{\prime}$ was also measured using a miniCTA and laminar burning velocities were determinates numerically using CHEMKIN-PRO.

In general for $\mathrm{CH}_{4} /$ air and syngas/ $\mathrm{CH}_{4} /$ air mixtures, $\mathrm{S}_{\mathrm{T}} / \mathrm{S}_{\mathrm{L}}$ increases with the increase of $\mathrm{u}^{\prime} / \mathrm{S}_{\mathrm{L}}$, and the rate of the increase of $\mathrm{S}_{\mathrm{T}} / \mathrm{S}_{\mathrm{L}}$ for the syngas $/ \mathrm{CH}_{4} /$ air mixture is higher than that $\mathrm{CH}_{4} /$ air mixtures, this behaviour can be attributed to the hydrogen content in the syngas by the diffusive effect.

With the increase of $\mathrm{S}_{\mathrm{L}}$, for the syngas/ $\mathrm{CH}_{4} /$ air mixture, the blow off tendency is expected to improve when compared to a flame of pure methane.

It was found that for a blockage of $88 \%$, the addition of syngas increases turbulent burning velocity in $10.3 \%, 3.3 \%$, and $4 \%$ for $0.8,0.9$ and 1.0 of equivalence ratios, respectively. For the other blockages the behaviour is similar to the blockage of $88 \%$.

\section{Acknowledgements}

The authors would like to acknowledge the GASURE group and the program "Sostenibilidad 20162017" of the University of Antioquia for the valuable economic contribution for the development of this project.

\section{References}

[1] Turns, S. R. An Introduction to Combustion Concepts and Applications, (2000). Singapore, 2000.

[2] Law, C. K. Combustion physics, (2006). 2006. .

[3] Heywood, J. B. Internal combustion engine fundaments, (1988). McGraw-Hill, inc, United States of America, 1988.

[4] Kobayashi, H. et al. Burning velocity correlation of methane/air turbulent premixed flames at high pressure and high temperature, Proc. Combust. Inst., 30 I (1) (2005), pp. 827-834.

[5] Wang, J. et al. Correlation of turbulent burning velocity for syngas/air mixtures at high pressure up to 1.0MPa, Exp. Therm. Fluid Sci., 50 (2013), pp. 90-96.

[6] Abdel-Gayed, R. G. and Bradley, D. A Two-Eddy Theory of Premixed Turbulent Flame Propagation, Philos. Trans. R. Soc. London. Ser. A, Math. Phys. Sci., 301 (1457) (1981), pp. 1-25.

[7] McAllister, S. et al. Fundamentals of Combustion Processes, (2011). Springer, 2011.

[8] David, B. Structure and propagation of turbulent bunsen flames, (1962). Washington, 1962.

[9] S. S. SHY, W. J. L. A. J. C. W. An experimental correlation of turbulent burning velocities for premixed turbulent methane-air combustion, 456 (2000) (2000), pp. 1997-2019.

[10] Jiang, L. J. et al. High-temperature, high-pressure burning velocities of expanding turbulent premixed flames and their comparison with Bunsen-type flames, Combust. Flame, 172 (2016), pp. 173-182. 
208 10 $10^{\text {TH }}$ InTERnational CONFERENCE ON Sustainable ENERGy AND ENVIRONMENTAL Protection (June $27^{\mathrm{TH}}-30^{\mathrm{TH}}, 2017$, Bled, Slovenia), Hydrogen ANd Fuel Cells

A. Cardona Vargas, A. M. García, F. E. Cano Ardila, C. E. Arrieta, H. A. Yepes \& A. A. Amell: Turbulent Burning Velocity of Mixture of Methane and a High Hydrogen Content Syngas

[11] Wabel, T. M. et al. Turbulent burning velocity measurements: Extended to extreme levels of turbulence, Proc. Combust. Inst., 36 (2) (2017), pp. 1801-1808.

[12] Chiu, C.-W. et al. High-pressure hydrogen/carbon monoxide syngas turbulent burning velocities measured at constant turbulent Reynolds numbers, Int. J. Hydrogen Energy, 37 (14) (2012), pp. 10935-10946.

[13] Shy, S. S. et al. Correlations of high-pressure lean methane and syngas turbulent burning velocities: Effects of turbulent Reynolds, Damköhler, and Karlovitz numbers, Proc. Combust. Inst., 35 (2) (2015), pp. 1509-1516.

[14] Arrieta, C. E. and Amell, A. A. Combustion analysis of an equimolar mixture of methane and syngas in a surface-stabilized combustion burner for household appliances, Fuel, 137 (2014), pp. 11-20.

[15] Amell, A. A. et al. Numerical and experimental study on laminar burning velocity of syngas produced from biomass gasification in sub-atmospheric pressures, Int. J. Hydrogen Energy, 39 (16) (2014), pp. 8797-8802.

[16] Burbano, H. J. et al. Laminar burning velocities and flame stability analysis of syngas mixtures at sub-atmospheric pressures, Int. J. Hydrogen Energy, 36 (4) (2011), pp. 32433252 .

[17] Kobayashi, H. et al. Burning velocity of turbulent premixed flames in a high-pressure environment, Symp. Combust., 26 (1996), pp. 389-396.

[18] Pareja, J. et al. Measurements of the laminar burning velocity of hydrogen-air premixed flames, Int. J. Hydrogen Energy, 35 (4) (2010), pp. 1812-1818.

[19] Kobayashi, H. et al. Turbulence measurements and observations of turbulent premixed flames at elevated pressures up to 3.0 MPa, Combust. Flame, 108 (1-2) (1997), pp. 104117.

[20] Wang, J. et al. Burning velocity and statistical flame front structure of turbulent premixed flames at high pressure up to 1.0 MPa, Exp. Therm. Fluid Sci., 68 (2015), pp. 196-204.

[21] Burbano, H. J. et al. Laminar burning velocities and flame stability analysis of H2/CO/air mixtures with dilution of $\mathrm{N} 2$ and CO2, Int. J. Hydrogen Energy, 36 (4) (2011), pp. 3232 3242 .

[22] Hai Wang, Xiaoqing You, Ameya V. Joshi, Scott G. Davis, Alexander Laskin, F. E. \& C. K. L. USC Mech Version II. High-Temperature Combustion Reaction Model of H2/CO/C1-C4 Compounds., (2007). 2007.

[23] Cardona, C. et al. Laminar Burning Velocity of Natural Gas/Syngas-Air Mixture, Dyna, 80 (180) (2013), pp. 136-143.

[24] Peters, N. Turbulent Combustion, (2000). Cambridge, 2000.

[25] Zhang, M. et al. Flame front structure and burning velocity of turbulent premixed CH4/H2/air flames, Int. J. Hydrogen Energy, 38 (26) (2013), pp. 11421-11428. 



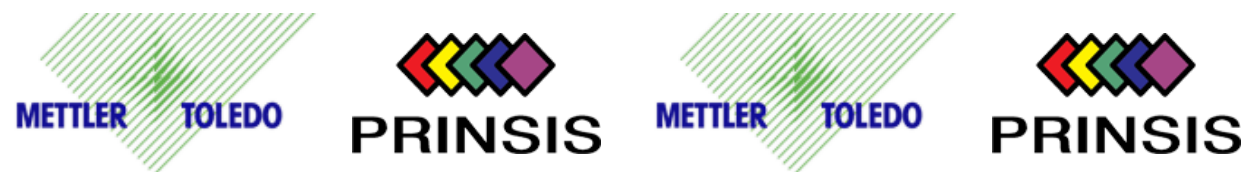

$€$ energetika ljubljana $€$ energetika ljubljana

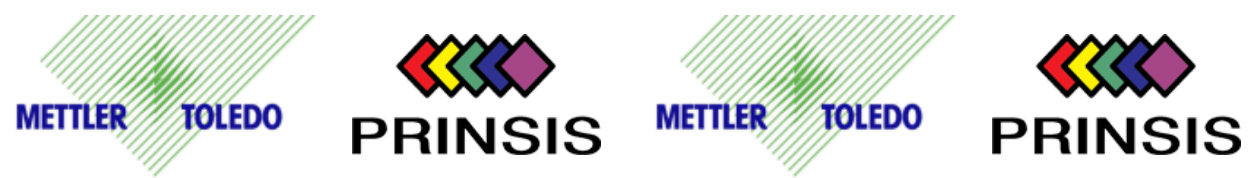

$€$ energetika ljubljana $€$ energetika ljubljana

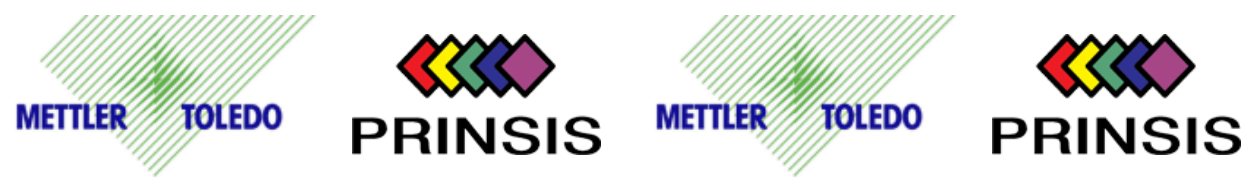

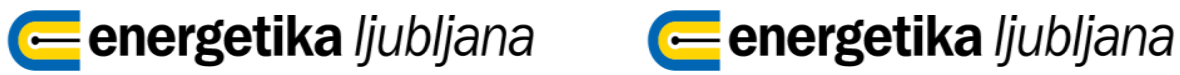

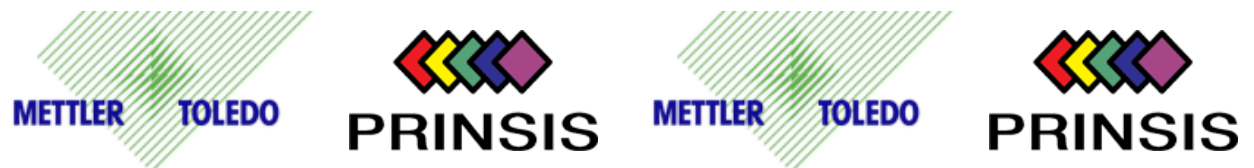

$€$ energetika ljubljana $€$ energetika ljubljana

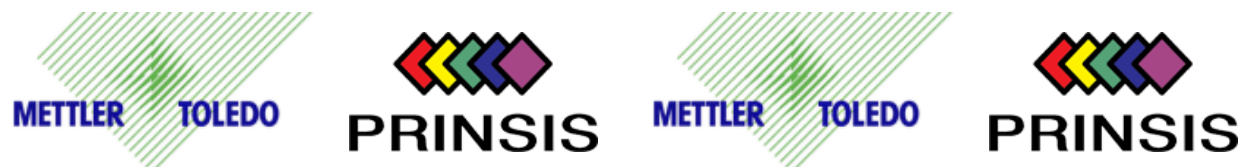

$€$ energetika ljubljana $€$ energetika ljubljana 